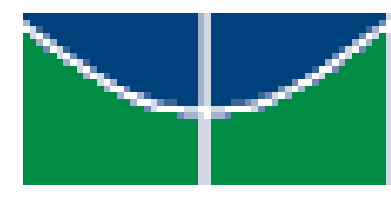

Universidade de Brasília - UNB

Faculdade de Arquitetura e Urbanismo - FAU

Programa de Pesquisa e Pós-graduação, PPG/FAU

Para onde vai o rural no DF?

\author{
Análise de processos sócio espaciais ocorridos nas \\ áreas rurais do Distrito Federal - de 1960 à 2000
}

Valéria Andrade Bertolini

Orientador: Prof. Dr. Rômulo José da Costa Ribeiro

Brasília

Dezembro de 2015 


\title{
Para onde vai o rural no DF? - Análise de processos sócio espaciais ocorridos nas áreas rurais do Distrito Federal - de 1960 à 2000.
}

\author{
Tese de doutoramento apresentada como \\ requisito parcial à obtenção do grau de \\ Doutor pelo Programa de Pesquisa e Pós \\ graduação da Faculdade de Arquitetura e \\ Urbanismo da Universidade de Brasília. \\ Orientador: Professor Doutor Rômulo José da \\ Costa Ribeiro
}

Brasília 


\section{TERMO DE APROVAÇÃO}

\section{VALÉRIA ANDRADE BERTOLINI}

Para onde vai o rural no DF? - Análise de processos sócio espaciais ocorridos nas áreas rurais do Distrito Federal - de 1960 à 2000

Tese aprovada como requisito parcial à obtenção do grau de doutor pelo Programa de Pesquisa e Pós-graduação da Faculdade de Arquitetura e Urbanismo da Universidade de Brasília.

Comissão Examinadora:

Professor Dr. Rômulo José da Costa Ribeiro (orientador)

Programa de Pós Graduação em Arquitetura e Urbanismo - UnB

Professor Dr. Daniel Richard Sant'Ana

Programa de Pós Graduação em Arquitetura e Urbanismo - UnB

Professora Dra. Gabriela de Souza Tenorio

Faculdade de Arquitetura e Urbanismo - UnB

Professora Dra. Liza Maria Souza de Andrade

Faculdade de Arquitetura e Urbanismo - UnB

Professora Dra. Tânia Cristina da Silva Cruz

Faculdade UnB Planaltina - FUP

Professor Dr. Valério Augusto Soares de Medeiros (suplente)

Programa de Pós Graduação em Arquitetura e Urbanismo - UnB 
Às minhas avós Maria e Ana, uma centenária e a outra chegando lá... O aprendizado da vida que a academia não traz! Mas Vó... há de ter serventia! 


\section{AGRADECIMENTOS}

Agradeço a Deus por todo o aprendizado de vida que passei nos últimos anos.

Aos que começaram, mas não terminaram essa estória comigo. Nem todo o aprendizado é suave.

À CAPES, pelo fomento à pesquisa.

À minha família, em especial aos meus pais. A distância física não os impediu de estar presente. E à uma parte da família do coração, que me acolheu com muito carinho. Seguimos 'Vivendo e Aprendendo'!

Aos meus amigos e pessoas queridas que me apoiaram e partilharam de vários momentos ao longo desse processo. Em especial: América, Nilton e Ronaldo, em nossos debates em Sobradinho; Professora Ignez, Marcela e Carla, em tantas fases dessa Tese; Rubens, Tatiana e companhia, pelo caminho do equilíbrio. Meus colegas e alunos da Católica, à Joyce e Rafael pelos mapas e Paul na formatação.

Ao Roberto, por tudo o que fez por mim na jornada interna que travei ao longo destes anos.

Ao meu orientador Rômulo, que não me deixou desistir, apoiando, mesmo em momentos difíceis.

Ao meu filho querido, perdão pelas ausências e obrigada por me fazer entender que o amor vale a pena. 


\section{RESUMO}

Esta tese se desenvolve a partir das áreas rurais do Distrito Federal, seus processos históricos e sua relação com as áreas urbanas. Apresenta uma forma diferenciada de analisar a expansão urbana, a partir das áreas rurais. Traz subsídios teóricos para os estudos de expansão urbana e, realiza um levantamento de informações sobre uso e ocupação do solo nas áreas rurais do DF. Levanta as seguintes questões: Qual o perfil das áreas rurais do DF? Há variações ao longo dos anos? Como e por quê? Qual o papel do planejamento 'espacial' nas áreas rurais do DF? Indução/retenção do crescimento urbano? Controle ambiental? Desenvolvimento agrícola? Com os processos de expansão urbana e especulação imobiliária, as áreas rurais no DF serão todas urbanas? Com a finalidade de entender a dinâmica da ocupação espacial das áreas rurais na região do Distrito Federal, considerando aspectos ambientais e socioeconômicos, definiu-se como objetivos específicos: a) Levantar contexto teórico sobre a expansão urbana em direção às áreas rurais; b) Analisar o processo histórico de conformação das áreas rurais do Distrito Federal; c) Caracterizar a situação atual das áreas rurais no DF: os tipos de uso e ocupação, as características da população, a situação fundiária dessas terras; d) Elaborar proposições a respeito do futuro das áreas rurais no DF. O método empregado na tese corresponde à análise de recorte temporal, empregando elementos de análise. Consiste numa periodização a partir de antecedentes à criação da Capital até a década de 2000. Os elementos de análise empregados foram denominados: aspectos econômicos, ambientais, sociais e espaciais. Ao final de cada capítulo há um resumo das análises desses elementos, retomados na discussão dos resultados. Várias conformações foram encontradas para as áreas rurais do DF. As mesmas se relacionam com discussões teóricas presentes na literatura. As áreas de produção agrícola se consolidam, apresentando variações de configurações espaciais. As áreas próximas às cidades tendem a se tornar urbanas. Os ambientes naturais - tanto urbanos, quanto rurais, sem proteção específica tendem à degradação, se não forem pensadas novas formas de ocupação do território do Distrito Federal, equilibrando ocupação urbana, produção agrícola e preservação ambiental.

Palavras chave: Planejamento urbano, planejamento espacial, áreas rurais, zonas de transição rural-urbana, Distrito Federal. 
This thesis develops from the rural areas of the Distrito Federal (DF), its historical processes and their relationship to urban areas. It presents a different way to look at urban sprawl from the rural areas. It brings theoretical basis for the studies of urban sprawl and conducts a survey of information on land use and occupation in rural areas of the DF. Raises the following questions: What is the profile of the rural areas of Distrito Federal? There are variations over the years? How and why? What is the role of the 'spatial' planning in rural areas of Distrito Federal? Induction / retention of urban growth? Environmental control? Agricultural development? With the processes of urban expansion and land speculation, rural areas in the Distrito Federal are all urban? In order to understand the dynamics of space occupation of rural areas in the Distrito Federal region, considering environmental and socioeconomic aspects, it was defined as specific objectives: a) Raise theoretical context on urban expansion into rural areas; b) Analyze the historical process of conformation of the rural areas of the Distrito Federal; c) To characterize the current situation of rural areas in the Distrito Federal: the types of use and occupation, population characteristics, the ownership status of these lands; d) To prepare proposals regarding the future of rural areas in Distrito Federal. The method used in the thesis corresponds to the time frame analysis, using instrumental elements. Is an accruals from prior to the creation of the Capital until the 2000s employees elements of analysis were named: economic, environmental, social and spatial. At the end of each chapter is a summary of the analysis of these elements taken up in the discussion of results. Various conformations were found in rural areas of the DF. They relate to theoretical discussions in the literature. The areas of agricultural production are consolidated, presenting variations of spatial configurations. The areas close to the cities tend to become urban. Natural environments - both urban and rural, with no specific protection - tend to degradation, if not thought out new forms of territorial occupation of the Distrito Federal, balancing urban settlement, agricultural production and environmental preservation.

Keywords: Urban planning, spatial planning, rural areas, areas of rural- urban transition, Federal District. 


\section{SUMARIO}

Agradecimentos v

Resumo vi

Abstract vii

Sumario viii

Índice de Figuras e Quadros $x$

Símbolos e abreviaturas xiv

INTRODUÇÃO 16

1. REVISÃO DA LITERTURA 25

1.1. Debate: rural e urbano 25

1.2. Instrumentos de planejamento relacionados a áreas rurais 29

1.3. Áreas de interface urbano-rural 33

1.4. A expansão urbana sobre o rural 36

1.5. Apontamentos sobre agentes e momento histórico 38

1.6. Elementos históricos da ocupação espacial brasileira 41

1.7. Trabalhos de referência sobre uso e ocupação do solo e áreas rurais no DF 50

2. MATERIAL E MÉTODOS 55

2.1. Material 55

2.2. Métodos 56

3. ÁREAS RURAIS DO DF AO LONGO DO TEMPO - IMPLANTAÇÃO 63

3.1. Antecedentes e período de implantação do DF 63

3.2. Década de 1960 75

3.3. Síntese do período 85

4. ÁREAS RURAIS DO DF AO LONGO DO TEMPO - CONSOLIDAÇÃO 90

4.1. Década de 1970 90 
4.2. Década de 1980 98

4.3. Síntese do Período 109

5. ÁREAS RURAIS DO DF AO LONGO DO TEMPO - TENTATIVAS DE ORDENAMENTO 114

5.1. Década de 1990 114

5.2. Década de 2000 125

5.3. Síntese do período 135

6. ANÁLISE DOS RESULTADOS 141

6.1. Configurações espaciais atuais das áreas rurais do DF 141

6.2. Conjecturas futuras 167 176 181 


\section{ÍNDICE DE FIGURAS E QUADROS}

\section{FIGURAS}

FIGURA 1: İNDICE DE GINI. FONTE: CPS/FGV A PARTIR DOS MICRODADOS DA PNAD, PME E CENSO / IBGE E LANGONI 1973

47

FIGURA 2: QUANTIFICAÇÃO MULTITEMPORAL DAS ÁREAS DE COBERTURA VEGETAL E USO DO SOLO (HA).

FONTE: UNESCO, 2002.

FIGURA 3: USO DO SOLO E VEGETAÇÃO DO DF EM 2001. FONTE: UNESCO, 2002.

FIGURA 4: CHEGADA DOS CANDANGOS PARA TRABALHAR NA CONSTRUÇÃO DA CAPITAL. 57

FIGURA 5: CEILÂNDIA NO COMEÇO, BARRACOS RECÉM-CONSTRUÍDOS - JUNHO DE 1971.

FIGURA 6: AGROVILA SÃO SEBASTIÃO EM MEADOS DE 1992.

FIGURA 7: CULTIVO DE MILHO NO PADF (FONTE: HTTP://WWW.COOPADF.COM.BR/FOTOS/69-DIA-DE-

CAMPO-MILHO-E-SOJA-2012); CANDANGO CHEGANDO À CAPITAL (FONTE: ARQUIVO PÚBLICO DF);

E ESTAÇÃO ECOLÓGICA DE ÁGUAS EMENDADAS (FONTE: HTTP://VERDECAPITAL.ORG) 61

FIGURA 8: PLANO PILOTO DE BRASÍLIA.

FIGURA 9: AGRICULTOR DESCENDENTE DE JAPONÊS, DA COLÔNIA AGRÍCOLA VARGEM BONITA PLANTA HORTALIÇAS EM CHÁCARA COM A IDADE DE BRASÍLIA 66

FIGURA 10: LOCALIZAÇÃO DOS LIMITES DAS ÁREAS INDICADAS PELA MISSÃO CRULS E PELO RELATÓRIO BELCHER, INCLUSIVE DOS SÍTIOS RECOMENDADOS, E DA ÁREA ATUAL DO DISTRITO FEDERAL. (FORTES ET.AL.2007, ADAPTADO DE SEMARH, 2001)

FIGURA 11: CARTA GEOGRÁFICA 1891 DE GOIÁS ELABORADA POR FRANCESCO TOSI COLOMBINA (HTTP://WWW.BRASIL.GOV.BR/ASSUNTOS/GERAL/2010/04/CARTA-GEOGRAFICA/03_MAPAFRANCESCOTOSICOLOMBINA.JPG/VIEW)

FIGURA 12: INDICAÇÃO DA OCUPAÇÃO URBANA EM 1953 SENDO BRASLÂNDIA À ESQUERDA E PLANALTINA À DIREITA. OBSERVA-SE QUE ERAM PEQUENOS NUCLEAMENTOS URBANOS. (FONTE: SEDUH)

FIGURA 13: FAZENDA DESAPROPRIADA ONDE HOJE SE LOCALIZA O PLANO PILOTO (FONTE: CORREIO BRASILIENSE)

FIGURA 14 DELIMITAÇÃO DAS FAZENDAS À ÉPOCA DA IMPLANTAÇÃO

FIGURA 15: ILUSTRAÇÃO ELABORADA POR PÉBAYLE COM A CONFIGURAÇÃO DAS ÁREAS RURAIS DO PERÍODO. (REVISTA IBGE, 1971)

FIGURA 16: A) VARGEM BONITA B) TAGUATINGA.

FIGURA 17: SOBRADINHO E ÁREAS RURAIS.

80

FIGURA 18: REGIÃO DE TABATINGA E RIO PRETO.

80

FIGURA 19: (A): COMÉRCIO CENTRAL DA CIDADE SATÉLITE DO GAMA E, (B) NÚCLEO BANDEIRANTE (NB) COM RESIDÊNCIAS DE BARRACOS DE DOIS PISOS EM LOTES EXÍGUOS (JUNHO DE 1971) FIGURA 20 OCUPAÇÃO URBANA EM 1964. (FONTE: SEDUH) 
FIGURA 21: GRÁFICOS DE USO DO SOLO ELABORADOS À PARTIR DE MATERIAL DA UNESCO (2002) SOBRE USO DO SOLO E VEGETAÇÃO NO DF

FIGURA 22: DESENHO ESQUEMÁTICO DA LOCALIZAÇÃO DE ALGUNS DOS PRINCIPAIS ELEMENTOS DO PERÍODO LEVANTADOS NAS CATEGORIAS DE ANÁLISE. (MAPA BASE: SEDHU).

FIGURA 23: FOTO DE 1986 COM A ÁREA DA FAZENDA SUCUPIRA (ATUALMENTE ÁREA DA EMBRAPA), GRANJAS IPÊ E RIACHO FUNDO. (FONTE: HTTP://WWW.SEDHAB.DF.GOV.BR/PRESERVACAO-EPLANEJAMENTO-URBANO/GESTAO-DA-INFORMACAO-URBANAS/MAPAS.HTML) 91

FIGURA 24: OCUPAÇÃO URBANA EM 1973. (FONTE: SEDUH)

FIGURA 25: PLANO ESTRUTURAL DE ORDENAMENTO TERRITORIAL - PEOT (FONTE:MANCINI APUD SEDUMA)

FIGURA 26: FOTOS DE 1975 E 1980 MOSTRANDO A INTENSIFICAÇÃO DA OCUPAÇÃO RURAL NOS NÚCLEOS RURAIS DE TABATINGA E RIO PRETO. FONTE: HTTP://WWW.SEDHAB.DF.GOV.BR/PRESERVACAO-EPLANEJAMENTO-URBANO/GESTAO-DA-INFORMACAO-URBANAS/MAPAS.HTML

FIGURA 27: LOCALIZAÇÃO DAS APAS DO DF. (FONTE: TERMO DE REFERÊNCIA PARANOÁ, 2012) 102 FIGURA 28: FOTO DE 1991 COM A ÁREA DA FAZENDA SUCUPIRA (ATUALMENTE ÁREA DA EMBRAPA), E CAUB I E II. (FONTE: HTTP://WWW.SEDHAB.DF.GOV.BR/PRESERVACAO-E-PLANEJAMENTOURBANO/GESTAO-DA-INFORMACAO-URBANAS/MAPAS.HTML)

FIGURA 29: FOTOS DE 1978 E 1986 COM OS NÚCLEOS RURAIS TAGUATINGA, VARGEM DA BÊNÇÃO E MONJOLO. ( HTTP://WWW.SEDHAB.DF.GOV.BR/PRESERVACAO-E-PLANEJAMENTO-

$\begin{array}{ll}\text { URBANO/GESTAO-DA-INFORMACAO-URBANAS/MAPAS.HTML) } & 104\end{array}$ FIGURA 30: OCUPAÇÃO URBANA EM 1984. (FONTE: SEDUH) 105 FIGURA 31: PLANO DE OCUPAÇÃO TERRITORIAL DO DISTRITO FEDERAL - POT. 107 FIGURA -32: PLANO DE OCUPAÇÃO E USO DO SOLO - POUSO. 108 FIGURA 33: GRÁFICOS DE USO DO SOLO ELABORADOS À PARTIR DE MATERIAL DA UNESCO SOBRE USO DO SOLO E VEGETAÇÃO NO DF (2002) FIGURA 34: DESENHO ESQUEMÁTICO COM A LOCALIZAÇÃO DE ALGUNS DOS PRINCIPAIS ELEMENTOS DO PERÍODO - DÉCADAS DE 1970 E 1980 - LEVANTADOS NAS CATEGORIAS DE ANÁLISE. (MAPA BASE: SEDHU)

FIGURA 35: RESERVA DA BIOSFERA DO CERRADO NO DF. FONTE:

HTTP://WWW.RBMA.ORG.BR/MAB/UNESCO_03_RB_CERRADO.ASP 116

FIGURA 36: ÁREAS DA FLORESTA NACIONAL 118

FIGURA 37: OCUPAÇÃO URBANA EM 1994 E 1998. (FONTE: SEDUH) 119

FIGURA 38: SITUAÇÃO FUNDIÁRIA DO DF DE 1995. (FONTE: SILVA, 2011, P.31 APUD ARQUIVOS

FUNDIÁRIOS DA SPU-DF, 2004). 122

FIGURA 39: PLANO DIRETOR DE ORDENAMENTO TERRITORIAL - PDOT/92. (FONTE:MANCINI APUD SEDUMA)

FIGURA 40: PDOT/1997: MACROZONEAMENTO. FONTE:ZEE,2009 124

FIGURA 41: PRODUÇÃO DE HORTALIÇAS E GRANDES CULTURAS - EMATER 2009 
FIGURA 42: PIVÔS-CENTRAIS INSTALADOS NO DISTRITO FEDERAL EM 2002. FONTE: SANO, ET ALL, 2005.

FIGURA 43: EVOLUÇÃO DAS PROPORÇÕES (\%), EM RELAÇÃO À ÁREA TOTAL, DAS ÁREAS MATAS PLANTADAS, PASTAGENS NATURAIS, PASTAGENS PLANTADAS, LAVOURAS PERMANENTES E LAVOURAS TEMPORÁRIAS NO DF ENTRE OS ANOS 1960 E 2000. FONTE: O CENTRO-OESTE BRASILEIRO COMO FRONTEIRA AGRÍCOLA, BASEADO EM DADOS DO IPEA 2005.

FIGURA 44: RESULTADO DA INTERAÇÃO ENTRE A SENSIBILIDADE AMBIENTAL DO TERRITÓRIO, COM RELAÇÃO AOS RISCOS DE PERDA DE SOLOS, DE RECARGA DE AQUÍFEROS E DE BIODIVERSIDADE, E A INTENSIDADE DE OCUPAÇÃO DAS ÁREAS RURAIS DADA PELO TIPO DE USO DO SOLO. (FONTE: ZEE DF A PARTIR DE MAPA DE USO DO SOLO DE 2009) 130

FIGURA 45: OCUPAÇÃO URBANA EM 2001 E 2006. (FONTE: SEDUH) 132

FIGURA 46: PDOT/2009: MACROZONEAMENTO. (FONTE: SEDUMA - 2009) 133

FIGURA 47: SITUAÇÃO FUNDIÁRIA 2009. (FONTE ZEE, 2010) 134

FIGURA 48: GRÁFICOS DE USO DO SOLO ELABORADOS À PARTIR DE MATERIAL DA UNESCO SOBRE USO DO SOLO E VEGETAÇÃO NO DF (2002) 136

FIGURA 49: DESENHO ESQUEMÁTICO COM A LOCALIZAÇÃO DE ALGUNS DOS PRINCIPAIS ELEMENTOS DO PERÍODO - DÉCADAS DE 1990 E 2000 - LEVANTADOS NAS CATEGORIAS DE ANÁLISE. (MAPA BASE: SEDHU)

FIGURA 50: INDICAÇÃO DAS GLEBAS RURAIS EXISTENTES NO DISTRITO FEDERAL (EM VERMELHO) FONTE:

ZEE, $2009 \quad 142$

FIGURA 51: IMAGENS AÉREAS DA VARGEM BONITA AO LONGO DOS ANOS 147

FIGURA 52: IMAGENS AÉREAS DE SOBRADINHO AO LONGO DOS ANOS 150

FIGURA 53: VICENTE PIRES 1964, 1986, 1991, 1997

FIGURA 54: VICENTE PIRES 2009 - FONTE: ZEE (2009) 153

FIGURA 55: TAGUATINGA, VARGEM DA BENÇÃO E MONJOLO DE 1965 A 2009

FIGURA 56: TENDÊNCIAS NA OCUPAÇÃO DO SOLO DAS ÁREAS RURAIS DO DF 174

\section{QUADROS}

QUADRO 1: DEBATE SOBRE O RURAL BRASILEIRO SEGUNDO CAMPOS E KRAHL 26

QUADRO 2: DIAGRAMA DA RELAÇÃO HISTÓRICA CIDADE/CAMPO, RURAL/URBANO 28

QUADRO 3: CARACTERIZAÇÃO DE AIPS SEGUNDO TIPOS DE CONCEITOS 33

QUADRO 4: HISTÓRICO DE PESQUISAS RELACIONADAS À EXPANSÃO DO URBANO SOBRE O RURAL 37

QUADRO 5: SÍNTESE - ANTECEDENTES E DÉCADA DE 1960, 89

QUADRO 6: DETALHAMENTO DAS APA'S DO DF. 101

QUADRO 7: SÍNTESE - DÉCADAS DE 1970 E 1980

QUADRO 8: SÍNTESE DÉCADAS DE 1990 E 2000

QUADRO 9: SÍNTESE DOS ASPECTOS ECONÔMICOS AO LONGO DAS DÉCADAS 168 
QUADRO 10: SÍNTESE DOS ASPECTOS AMBIENTAIS AO LONGO DAS DÉCADAS

QUADRO 11: SÍNTESE DOS ASPECTOS SOCIAIS AO LONGO DAS DÉCADAS

172

QUADRO 12: SÍNTESE DOS ASPECTOS ESPACIAIS AO LONGO DAS DÉCADAS 
SIGLA

AIPS

APA

CAESB

CAUB

CAUMA

CEASA

CEI

CENARGEN

CENARGEN

CODEPLAN

CONAMA

DF

DTA

EIA

EMATER

EMBRAPA

EPCT

ETA

FAL

FLONA

FLONA

FZDF

GDF

GEPAFI

GET/PI

IBGE

IDECON

INCRA

IPEA

JK

NOVACAP

PAD-DF

PDOT

PEOT

PERGEB

PIB

PIC/AG

PLANIDRO

\section{DESCRIÇÃO}

Áreas de interface periurbanas

Área de Proteção Ambiental

Companhia de Saneamento Ambiental do Distrito Federal

Combinado Agrourbano de Brasília

Conselho de Arquitetura, Urbanismo e Meio Ambiente

CEASA - Central de Abastecimento S/A

Campanha de Erradicação de Invasões

Centro Nacional de Recursos Genéticos

Centro Nacional de Recursos Genéticos

Companhia de Planejamento do Distrito Federal

Conselho Nacional do Meio Ambiente

Distrito Federal

Departamento de Terras e Agricultura

Estudo de Impacto Ambiental

Empresa de Assistência Técnica e Extensão Rural

Empresa Brasileira de Pesquisa Agropecuária

EPCT Estrada Parque Contorno

Escritório Técnico da Agricultura

Fazenda Água Limpa

Floresta Nacional de Brasília

Floresta Nacional de Brasília

Fundação Zoobotânica do Distrito Federal

Governo do Distrito Federal

Grupo Executivo para assentamento de favelas e invasões

Grupo Executivo de Trabalho para Parcelamentos Irregulares

Instituto Brasileiro de Geografia e Estatística

Índice de Desempenho Econômico do Distrito Federal

Instituto Nacional de Colonização e Reforma Agrária

Instituto de Pesquisas Econômicas Aplicadas

Juscelino Kubitscheck

Companhia Urbanizadora da Nova Capital

Programa de Assentamento Dirigido do Distrito Federal

Plano Diretor de Ordenamento do Distrito Federal

Plano Estrutural de Organização Territorial do DF

Programa Especial para a Região Geoeconômica de Brasília

Produto Interno Bruto

Projeto Integrado de Colonização Alexandre Gusmão

PLANIDRO - Pano Diretor de Água, Esgoto e Controle da Poluição do

Distrito Federal 


$\begin{array}{ll}\text { PNAD } & \text { Pesquisa Nacional por Amostra de Domicílios } \\ \text { POT - } & \text { Plano de Ocupação Territorial } \\ \text { POUSO } & \text { Plano de Ocupação e Uso do Solo } \\ \text { PRAT } & \text { Programa de assentamento de trabalhadores rurais } \\ \text { PRAT } & \text { Programa de assentamento de trabalhadores rurais } \\ \text { PROFLORA } & \text { PROFLORA - Florestamento e Reflorestamento S/A } \\ \text { PRÓ-RURAL } & \text { Plano de Desenvolvimento Rural do Distrito Federal } \\ \text { PROVE } & \text { Programa de Verticalização da Pequena Produção Agrícola } \\ \text { RA } & \text { Região Administrativa } \\ \text { RBCDF } & \text { Reserva da Biosfera do Cerrado no Distrito Federal } \\ \text { RBCDF } & \text { Reserva da Biosfera do Cerrado no Distrito Federal } \\ \text { REI } & \text { Região de Entorno Imediato } \\ \text { RGB } & \text { Região Geoeconômica de Brasília } \\ \text { RIDE/DF } & \text { Região Integrada de Desenvolvimento do Distrito Federal e Entorno } \\ \text { RIMA } & \text { Relatório de Impacto Ambiental } \\ \text { SAB } & \text { Sociedade de Abastecimento de Brasília } \\ \text { SCIA } & \text { Setor Complementar de Indústria e Abastecimento } \\ \text { SEAPA-DF } & \text { Secretaria de Agricultura, Pecuária e Abastecimento do Distrito } \\ \text { SÉC } & \text { Federal } \\ \text { SEDHAB } & \text { Século } \\ \text { SEDUH } & \text { Secretaria de Desenvolvimento Urbano e Habitação } \\ \text { SIA } & \text { Secretaria de Desenvolvimento Urbano e Habitação } \\ \text { SMPW } & \text { Setor de Indústria e Abastecimento } \\ \text { TERRACAP } & \text { Setor de Mansões Park Way } \\ \text { UNESCO } & \text { Companhia Imobiliária de Brasília } \\ \text { ZEE } & \text { Organização das Nações Unidas para a Educação, Ciência e Cultura } \\ \text { ZRU } & \text { Zoneamento Ecológico-Econômico } \\ & \text { Zona Rural }\end{array}$




\section{INTRODUÇÃO}

Estudos que envolvem características da ocupação espacial do Distrito Federal se desenvolvem a partir da análise urbana. Sob um prisma diferente, esta Tese se desenvolve a partir das áreas rurais, seus processos históricos e sua relação com as áreas urbanas. Sua contribuição aos estudos de planejamento espacial compreende:

$\checkmark$ Apresentar uma forma diferenciada de analisar a expansão urbana, a partir das áreas rurais.

$\checkmark$ Trazer subsídios teóricos para os estudos de expansão urbana.

$\checkmark$ Realizar um levantamento de informações sobre uso e ocupação do solo em áreas rurais do DF.

$\checkmark$ Elaborar conjecturas futuras para as áreas rurais do DF.

Atualmente a maioria da população brasileira se encontra vivendo nas cidades. Dados do Censo do IBGE de 2010 apontavam 84\% de população urbana ${ }^{1}$. No Distrito Federal, dados da PNAD de 2012 indicaram 95,6\% de população urbana². Historicamente, o excedente de mão-de-obra do campo passou a ser atraído pela expansão das atividades industriais nos grandes centros, tornando-se 'exército de reserva' do capitalismo industrial. Segundo Maricato: “os interesses urbanos industriais conquistam a hegemonia na orientação da política econômica sem, entretanto, romper com relações arcaicas de mando baseadas na propriedade fundiária". (MARICATO, 2002, p.31). Tem-se, por um lado, processos de industrialização e urbanização, e, por outro, processos inconclusos de reforma agrária.

As questões fundiárias da população do campo não foram resolvidas, e com o aumento do êxodo rural devido à migração, aumentaram também os problemas fundiários nas cidades. Ocorre então, um inchaço da população das periferias dos grandes centros e surgimento de favelas. A oferta de infraestrutura urbana encontra-

\footnotetext{
${ }^{1}$ Dados do Censo do IBGE (Instituto Brasileiro de Geografia e Estatística). Disponível em: http://www.ibge.gov.br/home/estatistica/populacao/censo2010/default atlas.shtm

${ }^{2}$ http://www.ibge.gov.br/home/estatistica/populacao/trabalhoerendimento/pnad2013/default.shtm
} 
se sempre defasada em relação à demanda. São criados loteamentos populares distantes dos centros, incentivando a especulação imobiliária em bolsões vazios. Começam a surgir problemas ambientais decorrentes da ocupação de morros e de outras áreas impróprias para a moradia. A violência nas cidades cresce à medida que cresce o desemprego. Nesse crescimento contínuo das cidades, transbordam para as áreas de transição rural-urbanas os conflitos fundiários entre especulação e luta pela moradia. O estoque de terras existente nestes locais encontra-se interligado à rede de recursos hídricos, atividades agrícolas e bioma local.

Nas áreas rurais, o uso de agrotóxicos, relacionado ao processo de modernização tecnológica na agricultura ${ }^{3}$, traz consigo impactos nos ecossistemas locais, como por exemplo, contaminações do solo e do lençol freático. As áreas necessárias à proteção ambiental - como nascentes, cursos d'água, fauna e flora nativas - juntamente com a população local, ficam sujeitas às consequências dos processos de produção e ocupação do espaço rural.

Os pontos levantados acima fazem parte das motivações pessoais para a realização desta pesquisa: abordar questões rurais e ambientais no debate do planejamento municipal. Tendo proximidade com o tema da Reforma agrária, desenvolvi trabalhos em áreas rurais e realizei Mestrado ${ }^{4}$ em área de assentamento rural. Embora a pesquisa realizada no mestrado envolvesse municípios do interior de Minas Gerais (Unaí, Buritis, Arinos), com forte economia agrícola, não percebi diálogo entre as políticas urbanas e rurais dos municípios. Esse descompasso, ou desencontro, entre o planejamento de áreas urbanas e rurais, é um ponto que sempre me incomodou. Considero que as questões urbanas, rurais e ambientais de um município devem ser tratadas em conjunto, pois uma se relaciona diretamente com a outra. Apesar de corresponderem a distintos mecanismos de configuração espacial, as áreas urbanas e rurais fazem parte de um mesmo sistema, onde as ações que ocorrem de um lado repercutem no outro. As consequências dos problemas ambientais, como os

\footnotetext{
${ }^{3}$ Os altos índices de uso de agrotóxicos estão relacionados ao processo de modernização tecnológica, denominado Revolução Verde, que modificou profundamente as práticas agrícolas, gerou mudanças ambientais, nas cargas de trabalho e nos seus efeitos sobre a saúde (CARNEIRO, 2007, p.85).

4 "Ocupando o Cerrado - avaliação do processo de implantação de assentamentos rurais no entorno do Distrito Federal". (Dissertação defendida na FAU/UNB em 2005).
} 
agravos causados pela contaminação dos recursos hídricos, envolvem todo o município, independente do local de origem.

As atuações dos poderes públicos, criando separação de competências entre os espaços urbanos e rurais, fragmentam a atuação no território. As zonas de transição rural-urbana se encontram numa lacuna gerada por essa separação. Neste caso, a ausência de mecanismos de controle social e ambiental viabiliza o controle do mercado.

Realizar de forma integrada o planejamento dos espaços urbanos e rurais, com uso adequado dos recursos naturais, compreende envolver a totalidade do município, respeitando as peculiaridades de cada local. Portanto, o ponto de partida para a realização desse trabalho foi a necessidade de se pensar um planejamento que integrasse áreas urbanas e rurais na busca do controle do uso dos recursos naturais e garantisse melhores condições de vida para a população marginalizada do campo e das periferias urbanas.

$\mathrm{Na}$ realidade da maioria dos municípios brasileiros, as áreas rurais são atendidas principalmente por políticas e legislações federais, e, a área urbana, pela atuação do governo municipal. No caso de Brasília, devido a sua especificidade de capital federal criada e planejada (projetada), encontram-se características que poderiam remeter a uma situação ideal de planejamento envolvendo áreas urbanas e rurais. A propriedade pública da terra - devido à desapropriação de boa parte das terras do Distrito Federal - e a elaboração de políticas de gestão do território proporcionam maior autonomia e controle por parte do governo do Distrito Federal. Ocorre ainda, uma maior presença de recursos públicos para garantir a segurança e manutenção da sede do governo federal.

No entanto, a ocupação do Distrito Federal é marcada por um processo de segregação espacial. A Implantação de Brasília atraiu levas de migrantes para a realização das obras e na busca de melhores condições de vida. As famílias dos operários que se fixaram em favelas/ocupações e assentamentos irregulares na região do Plano Piloto foram paulatinamente removidas para cidades satélites criadas para alojá-las. Buscou-se garantir a execução do projeto urbanístico do Plano Piloto 
vencedor do concurso para a nova capital, sem, entretanto, fazer um planejamento de crescimento urbano a partir desse núcleo. Essa concepção gerou uma ocupação polinucleada e desigual, com uma grande dependência do núcleo central:

[...] ao projetar Taguatinga, em 1958, o governo local deflagrou um processo de interminável criação de cidades-satélites - todas visando proteger o Plano Piloto de ocupações ilegais, irregulares e informais (favelas), as denominadas "invasões". Desfecha, ao mesmo tempo, o polinucleamento urbano e a periferização com segregação socioespacial. (PAVIANI, 2009, p.80).

$\mathrm{Na}$ implantação da capital, as áreas rurais foram idealizadas para abastecer os núcleos urbanos e realizar um cinturão verde de proteção do plano piloto. Essas áreas deveriam ser arrendadas a produtores agrícolas. No entanto, a seleção de agricultores não foi criteriosa e faltou fiscalização no uso das parcelas. O acesso à infraestrutura (estradas e energia) e a proximidade da área urbana atraíram o interesse de outras atividades (recreativas, lazer, etc.) alheias à proposta inicial de cultivo agrícola. Outros pontos que também interferiram na produção agrícola das áreas rurais foram: o aumento do preço da terra nas proximidades dos núcleos urbanos, propiciando a especulação imobiliária, e a desapropriação inconclusa, que causou conflitos no processo fundiário. A ocupação segregada no Distrito Federal garantiu a existência de vazios urbanos com um potencial valor agregado. Com a desapropriação inconclusa das áreas rurais, houve uma pressão para a ocupação desses vazios, num processo de especulação imobiliária.

Ao observar a realidade de expansão urbana da Brasília metrópole sobre suas áreas rurais - loteamentos clandestinos, especulação imobiliária, impactos ambientais, entre outros - constata-se situação semelhante às demais metrópoles brasileiras, apesar das políticas públicas locais e dos diversos planos de ordenamento territorial ${ }^{5}$ elaborados. O processo da ocupação de regiões metropolitanas, onde atuam agentes públicos e privados apresenta descontinuidades urbanas, com bolsões de áreas agrícolas e de reservas ambientais. Impactos ambientais, dificuldade de abastecimento de água, de implantação de redes de transporte e infraestrutura são algumas das consequências do crescimento da mancha urbana.

${ }_{5}^{5}$ Destacam-se o PEOT/78, РОT/85, Brasília Revisitada/87, POUSO/90, PDOT/92, PDOT/97 e PDOT/2009. 
Apresentam-se então as seguintes situações:

$\rightarrow$ O descompasso das políticas para áreas urbanas e rurais e a necessidade de uma maior integração entre elas;

$\rightarrow$ A realidade do Distrito Federal, com um processo histórico de tentativas de ordenamento do território e;

$\rightarrow$ A expansão urbana no Distrito Federal em direção às áreas rurais.

O estudo de processos de uso e ocupação do solo nas áreas rurais do Distrito Federal compreenderia abarcar temas como relações urbano-rurais, políticas de ordenamento envolvendo urbano e rural e áreas rurais em regiões de expansão metropolitana.

Porém, apesar de apresentar problemas existentes nos demais municípios brasileiros, o DF apresenta situações atípicas, não sendo representativo das transformações rurais em geral. Seu contexto de capital federal abrangendo delimitação espacial, planejamento e controle estatal, terras públicas, recursos públicos federais, ocupação polinucleada e outros pontos abordados aqui, indica uma situação específica.

Corroborando com as especificidades locais, sua economia se desenvolve no âmbito do setor de serviços, relacionando-se com as características administrativas do Distrito Federal. Conforme resultados do Índice de Desempenho Econômico do Distrito Federal (IDECON), o setor Agropecuário no Distrito Federal exerce pequeno impacto nas atividades produtivas. No PIB de 2010 respondia por apenas 0,3\% da estrutura produtiva6, seguido da indústria (6,5\%); já o Setor Terciário (serviços), representou 93,2\% do PIB em 2010.

\footnotetext{
A agricultura local é desenvolvida em pequenas áreas, dada a dimensão territorial do Distrito Federal, e qualquer fator que atinja as áreas de cultivo, como efeito climático, infestação de pragas ou aplicação de novas tecnologias interfere fortemente na produção das lavouras, com grande impacto no índice do setor Agropecuário. (CODEPLAN, 2014 p.13)
}

\footnotetext{
${ }^{6}$ No atual cálculo do setor Agropecuário, considera-se apenas o desempenho das principais culturas agrícolas no Distrito Federal: soja, milho, feijão e tomate, além de batata-inglesa, mandioca e laranja. Para os demais produtos, há indisponibilidade de informações conjunturais. (CODEPLAN, 2014 p.13)
} 
Ao verificar os estudos sobre o Distrito Federal, as análises históricas de ocupação espacial do DF comumente abordam aspectos do crescimento urbano ${ }^{7}$. Por outro lado, as análises de áreas rurais direcionam-se a aspectos produtivos ou de degradação ambiental.

O foco do estudo direciona-se então, especificamente, para a análise das áreas rurais na região de Brasília $^{8}$, seu processo histórico de conformação, a realidade atual e seu futuro.

Portanto, este trabalho envolve questões do crescimento urbano no Distrito Federal sob outro ângulo, a partir do rural. A perspectiva de análise parte do viés da realidade das áreas rurais para as urbanas. Pretende-se analisar transformações ocorridas nas áreas rurais do Distrito Federal desde sua criação; abordando a ocupação espacial, aspectos ambientais e socioeconômicos.

O objetivo a ser alcançado compreende entender as transformações ocorridas ao longo do tempo nas áreas rurais do Distrito Federal, abarcando sua especificidade de Capital Federal. Portanto, tem-se como objetivo geral: "Entender a dinâmica da ocupação espacial das áreas rurais na região do Distrito Federal considerando aspectos ambientais e socioeconômicos."

Para auxiliar nesse processo, são delimitados os seguintes objetivos específicos:

Levantar contexto teórico sobre a expansão urbana em direção às áreas rurais;

Analisar o processo histórico de conformação das áreas rurais do Distrito Federal;

Caracterizar a situação atual das áreas rurais no DF: os tipos de uso e ocupação, as características da população, a situação fundiária dessas terras;

Elaborar proposições a respeito do futuro das áreas rurais no DF.

7 Neste sentido destacam-se os livros da Coleção Brasília, teses e dissertações defendidas, em sua maioria, nos departamentos de Arquitetura e Geografia da UNB. A revisão bibliográfica em relação a uso e ocupação do solo das áreas rurais será abordada no final do próximo capítulo.

${ }^{8}$ Nesta tese Brasília é sinônimo de Distrito Federal. 
Visando alcançar os objetivos descritos, o objeto deste estudo compreende as áreas rurais do Distrito Federal - analisadas desde o período de implantação da Capital até o ano de 2000.

O emprego do termo "áreas rurais" nesta pesquisa abrange as áreas delimitadas como não urbanas pelos Planos Diretores. Os tipos de usos e caracterizações podem variar desde áreas de transição urbano-rurais ${ }^{9}$, áreas de uso agrícola, de controle ambiental, turismo rural e outros.

O que se observa hoje na conformação de Brasília é semelhante à realidade de outras regiões brasileiras: um avanço desordenado de ocupação urbana em direção às áreas rurais por meio da segregação da população de baixa renda, condomínios fechados e especulação imobiliária. Um indicador do processo de avanço do urbano sobre o rural, em nossa área de estudo, é o aumento das áreas urbanas e a diminuição das áreas rurais na sequência dos planos de ordenamento territorial. O surgimento de novas regiões administrativas em antigos núcleos rurais, os condomínios e ocupações irregulares e a dificuldade de controlar as invasões nas áreas de restrições ambientais fazem parte dessa conjuntura.

A par dessas questões, uma primeira hipótese formulada sugere que a existência de políticas públicas e o controle estatal do uso da terra não foram suficientes para alcançar um planejamento urbano-rural de forma a garantir a função social ${ }^{10}$ da terra e o uso adequado dos recursos naturais. Porém, com o avanço desenfreado do urbano sobre o rural, devido à necessidade de moradia e a especulação imobiliária fruto da valorização das terras no Distrito Federal, levanta-se as seguintes questões:

$\checkmark$ Qual o perfil das áreas rurais do DF? Há variações ao longo dos anos? Como e por quê?

\footnotetext{
${ }^{9}$ Geralmente representam áreas de avanço urbano sobre o rural, apresentando características urbanas e rurais.

${ }^{10} \mathrm{O}$ art.182, § $2^{\circ}$ da CF estabelece que, a propriedade urbana cumpre sua função social quando atende às exigências fundamentais de ordenação da cidade expressas no Plano Diretor. No caso do DF os Planos abrangem as áreas urbanas e rurais. Segundo o art. 186 da CF, a propriedade rural atende sua função social quando há: aproveitamento racional e adequado, utilização adequada dos recursos naturais, preservação do meio ambiente, atendimento a leis trabalhistas e exploração que favoreça o bem estar do proprietário e do trabalhador.
} 
$\checkmark$ Qual o papel do planejamento 'espacial' nas áreas rurais do DF? Indução/retenção do crescimento urbano? Controle ambiental? Desenvolvimento agrícola?

$\checkmark$ Com os processos de expansão urbana e especulação imobiliária, as áreas rurais no DF serão todas urbanas?

Numa região metropolitana a pressão urbana sobre as áreas rurais influencia os modos de ocupação dessas áreas. Questões urbanas se sobrepõem a questões rurais: quando o rural não se urbaniza, atua em função do urbano. Porém, nesse ínterim, há situações onde o rural se reedita e novas conformações são criadas.

Novo e velho se encontram ambos, permanentemente, em estado de mudança, que é dialética. Sendo contraditórios, funcionam, porém, em forma complementar e conjunta. As combinações do novo e do velho variam segundo os lugares. (Santos, 2008, p.106).

Buscando trabalhar as questões acima, a estruturação do texto da tese compreende: I) revisão da literatura, trazendo referenciais para embasar a análise; II) definição do método de estudo, delimitando categorias de análise para trabalhar informações das áreas rurais do DF ao longo do tempo; III) estudo das áreas rurais separado por décadas, empregando as categorias de análise; IV) discussão das configurações atuais e conjecturas futuras para as áreas rurais V) contribuições do trabalho para o debate das áreas metropolitanas.

Ao levantar as teorias sobre a expansão urbana em direção às áreas rurais foram enfatizadas correntes teóricas que abordam a urbanização da sociedade na linha de Henry Lefebvre. Mais do que uma dicotomia antagônica entre rural e urbano, seus usos são definidos pelas relações socioeconômicas que regem a sociedade contemporânea.

Para a revisão da literatura sobre o assunto foram abordados instrumentos de planejamento relacionados a áreas rurais, o debate rural e urbano, as áreas de interface urbano-rural, a expansão urbana sobre o rural, a expansão urbana em áreas metropolitanas e apontamentos sobre agentes e momento histórico. Outro ponto abordado é uma contextualização socioeconômica e política de elementos históricos da ocupação espacial brasileira. Finaliza o capítulo uma revisão da bibliografia de estudos relacionados à uso e ocupação do solo em áreas rurais do Distrito Federal. 
O capítulo de material e métodos compreende os instrumentos de coleta de dados e os métodos empregados. Descreve as perspectivas de análise no recorte temporal e como foram definidos os elementos de análise - econômico, ambiental, social e espacial. Para entender o que ocorre em determinado local, é importante entender seu contexto num período histórico. Essa premissa foi empregada na elaboração do método da tese abordando a periodização. Aplicando os critérios de análise definidos no método de pesquisa, os capítulos seguintes abordam as áreas rurais do Distrito Federal ao longo do tempo. Consistem numa periodização a partir de antecedentes à criação da Capital até a década de 2000.

$\mathrm{Na}$ pesquisa do processo histórico de conformação das áreas rurais houve acentuada dificuldade em relação às fontes de dados. Muitas informações não foram encontradas em todos os períodos, ou eram abordadas de forma diferenciada entre eles - como dados de produção agrícola e locais de produção. Em muitos casos os dados eram conflitantes - como ocorreu muitas vezes na definição se um local era rural ou urbano. Esta questão acabou impossibilitando comparações estatísticas, mas não inviabilizando a pesquisa. Serviu para direcionar tendências observadas nos períodos seguintes.

Na discussão dos resultados, a caracterização de áreas rurais no DF também apresenta problemas similares. As transformações ocorridas nos locais nem sempre são quantificadas nos órgãos oficiais. Outro ponto é o viés de abordagem: a SEDHAB enfatiza o que está nos Planos Diretores, a TERRACAP a titularidade da terra, a EMATER aspectos produtivos, a Caesb sua área de abrangência... A ênfase no tratamento das áreas rurais segue o campo de atuação de cada órgão.

$\mathrm{Na}$ discussão dos resultados busca-se trazer contribuições ao debate urbanorural por meio: do exame de situações do quadro atual das áreas rurais do DF, relacionando-as com a revisão da literatura; e das conjecturas futuras, sob o viés das variáveis de análise. 


\section{REVISÃO DA LITERTURA}

Para estudar questões sócio espaciais, ocorridas em áreas rurais do Distrito Federal, buscou-se abordagens sobre relações urbano-rural, envolvendo aspectos conceituais e históricos. Foram revisados os seguintes assuntos:

$\rightarrow$ O debate das definições entre o que é rural e o que é urbano.

$\rightarrow$ As legislações sobre o tema - envolvendo Instrumentos de planejamento relacionados a áreas rurais.

$\rightarrow$ Áreas de interface entre os espaços rurais e urbanos - a situação das áreas que não são propriamente urbanas nem rurais.

$\rightarrow$ Levantamento de estudos e abordagens referentes à expansão urbana sobre áreas rurais;

$\rightarrow$ Debates teóricos sobre a participação de agentes sociais e momentos históricos;

$\rightarrow$ Uma revisão de elementos históricos da ocupação espacial brasileira; entender as características históricas da urbanização brasileira e as alterações ocorridas no campo no país.

$\rightarrow$ Revisão bibliográfica sobre uso e ocupação do solo no DF e áreas rurais.

\subsection{Debate: rural e urbano}

Em 1938, no Estado Novo, por intermédio do Decreto-Lei 311, todas as sedes municipais existentes foram transformadas em Cidades. Atualmente, a delimitação do perímetro urbano de uma cidade, distinguindo área urbana de rural, ocorre a partir da aprovação de lei municipal na Câmara dos Vereadores. Mas, o que é considerado rural e urbano, no atual debate científico, vai além dessa linha imaginária definida por limites político-administrativos.

Sparovek, Leonelli e Barreto (2004) buscam fazer uma caracterização do que seria urbano e rural. O urbano pode ser reconhecido pela extensão e oferta dos serviços públicos e pela densidade populacional e viária, podendo ou não existir produção agrícola. No rural a extensão dos serviços e equipamentos públicos é restrita ou parcial, a dimensão das propriedades é maior, predominam atividades agrícolas e 
áreas de preservação; há enclaves de urbano sem haver continuidade espacial entre eles. (SPAROVEK et al, 2004).

Em relação ao rural, Neio Campos e Mara F. L. Krahl apontam quatro perspectivas do debate sobre sua conceituação no Brasil (sintetizadas no quadro 1) e definem o âmbito do rural como:

[...] o território construído a partir do uso e da apropriação dos recursos naturais, onde se originam processos produtivos, culturais, sociais e políticos. A dimensão do rural incorpora áreas dispersas e concentrações urbanas que se explicam por sua relação com os recursos naturais. Compreende uma ampla diversidade de setores econômicos, interdependentes, envolvendo dimensões não econômicas e estabelecendo relações funcionais com o urbano. (CAMPOS E KRAHL, 2006, p.87).

Quadro 1: Debate sobre o rural brasileiro segundo Campos e Krahl

\begin{tabular}{|c|c|c|}
\hline Enfoque & Caracterização & Principais Autores \\
\hline $\begin{array}{c}\text { Continuum (Novo rural } \\
\text { brasileiro) }\end{array}$ & $\begin{array}{c}\text { Percebe o rural mais sob a influência do urbano } \\
\text { que em relação às características do próprio } \\
\text { rural. }\end{array}$ & Graziano da Silva \\
\hline $\begin{array}{l}\text { Territorial (Valorização } \\
\text { das dimensões } \\
\text { espaciais) }\end{array}$ & $\begin{array}{c}\text { Reconhece o tratamento do rural como } \\
\text { paisagem a ser consumida. Criticada pelo seu } \\
\text { caráter instrumental. }\end{array}$ & José Eli da Veiga \\
\hline $\begin{array}{l}\text { Sociabilidade (critica o } \\
\text { continuum e o } \\
\text { territorial) }\end{array}$ & $\begin{array}{c}\text { Defende a ideia de fortalecimento da ruralidade, } \\
\text { onde as transformações no meio rural realçam } \\
\text { suas especificidades. Valoriza formas de } \\
\text { organização social locais. }\end{array}$ & $\begin{array}{c}\text { Carneiro, Wanderlei e } \\
\text { Marques }\end{array}$ \\
\hline Capital social & $\begin{array}{c}\text { Aponta proposições para a formação e o } \\
\text { fortalecimento do capital social no meio rural } \\
\text { trabalhando com redes territoriais. }\end{array}$ & Abramovay \\
\hline
\end{tabular}

Veiga (2003) critica a metodologia oficial usada pelo IBGE na separação das áreas urbana e rural ${ }^{11}$. Em seu livro “Cidades imaginárias" levanta outra proposta baseada em dados estatísticos. Mas, segundo Sobarzo (2010), trata-se de abandonar um critério formal e adotar outro. Para este autor, baseado da obra de Lefebvre, o urbano indica uma sociedade em formação na qual está incluído o rural (ou as atividades denominadas rurais).

11 A partir de 1991, o IBGE definiu três categorias de áreas urbanas (urbanizadas, nãourbanizadas e urbanas-isoladas) e quatro tipos de aglomerados rurais (extensão urbana, povoado, núcleo e outros) 
Medeiros assinala uma re-valorização de atividades rurais não agrícolas decorrentes das transformações no meio rural (moradia, turismo, lazer, prestação de serviços, preservação do meio ambiente). Aponta novas conformações do meio rural brasileiro, segundo atividades levantadas por José Graziano da Silva ('novo rural') a partir da década de 1980: (i) uma agropecuária moderna, ligada à agroindústria e baseada em commodities $^{12}$; (ii) um conjunto de atividades não agrícolas, ligadas à moradia, ao lazer, a atividades industriais e de prestação de serviços e; (iii) um conjunto de novas atividades agropecuárias, localizadas em nichos especiais de mercado. Mas, segundo a autora, são novas ruralidades num espaço que é marcado pela presença forte de seus velhos personagens: os ruralistas, os latifundiários, os produtores familiares, os camponeses com ou sem terra. Aponta ainda que dentro dessas contradições se encontra parte significativa de sua população rural excluída do processo produtivo. (MEDEIROS, 2011).

$\mathrm{Na}$ área da sociologia rural, Wanderlei aponta que as relações entre o meio rural e as cidades não podem ser entendidas como relações de oposição ou antagonismos, mas se inscrevem num espaço comum como relações de complementaridade e interdependência. A autora aponta ainda, na integração do mundo rural com a sociedade urbano-industrial, as populações rurais como sujeitos de direitos, transformando o acesso a bens e serviços como o exercício de sua cidadania. (Wanderlei, 2010)

Segundo Rua (2011), não há fronteiras precisas que delimitem rural e urbano e também não existem características essenciais para definir o rural. Aponta ainda que a ênfase na ruptura pode provocar uma supervalorização das distinções campo-cidade e rural-urbano não contemplando a totalidade do espaço. Já a ênfase na continuidade/contiguidade pode conduzir a uma subvalorização da diversidade do rural.

${ }^{12}$ Commodities - palavra em inglês, que significa mercadoria. Usada para descrever produtos de baixo valor agregado. Pode ser sinônimo de "matéria-prima", porque são produtos usados na criação de outros bens. Como seguem um determinado padrão, o preço das commodities é negociado na Bolsa de Valores Internacionais. Se dividem em quatro categorias: minerais (petróleo, ouro, minério de ferro, etc.), financeiras (real, euro, dólar, etc.), ambientais (água, madeira, energia, etc.) e agrícolas (soja, trigo, café, algodão, borracha, etc.). 
Bernardelli considera impossível uma definição universal para o meio rural considerando as diversidades existentes. Ao se falar de espaço, seja rural ou urbano, deve-se sempre considerar suas especificidades, decorrentes de sua construção histórica:

Longe de consensos, o entendimento do rural e do urbano não deve se valer de uma definição no sentido estrito, mas se apoiar num conjunto de elementos que possa permitir a leitura de um espaço num determinado tempo, pois sendo a realidade sujeita a constantes transformações é preciso sempre se redimensionar os conceitos que permitem sua compreensão. (BERNADELLI, 2010, p. 48)

Carlos (2004, p.130) aponta que "cidade e campo se diferenciam pelo conteúdo das relações sociais neles contidas e estas, hoje, ganham conteúdo em sua articulação com a construção da sociedade urbana". Para ela, a discussão, entre o que é urbano e o que é rural, não ficaria na questão formal e sim no conteúdo.

Limonad coloca que o campo e a cidade estão relacionados a paisagem, a forma, a representações do espaço, enquanto que rural e urbano se relacionam a qualidade, conteúdo e são efetivados por relações sociais. Considera que cidade e campo, enquanto formas podem ser entendidas, historicamente, como expressões ou manifestações concretas no espaço social do urbano e do rural. (LIMONAD, 2010). A autora ainda busca sintetizar num diagrama sua relação histórica:

Quadro 2: Diagrama da relação histórica cidade/campo, rural/urbano

\begin{tabular}{|c|c|c|c|}
\hline Tempo & Forma & Qualidade/conteúdo & Função \\
\hline \multirow[t]{2}{*}{ 1a Revolução Industrial } & Cidade & Urbano & $\begin{array}{l}\text { Políticas } \\
\text { Ofícios } \\
\text { Serviços }\end{array}$ \\
\hline & Campo & Rural & $\begin{array}{l}\text { Agricultura } \\
\text { Indústria }\end{array}$ \\
\hline \multirow[t]{2}{*}{ 2a Revolução Industrial } & Cidade & Urbano & $\begin{array}{l}\text { Política } \\
\text { Indústria } \\
\text { Serviços }\end{array}$ \\
\hline & Campo & Rural & Agricultura \\
\hline \multirow{2}{*}{ 3a Revolução Industrial } & Cidade & Urbano? & $\begin{array}{l}\text { Política } \\
\text { Indústria } \\
\text { Serviços }\end{array}$ \\
\hline & Campo & Rural? & $\begin{array}{c}\text { Agricultura } \\
\text { Indústria } \\
\text { Serviços }\end{array}$ \\
\hline
\end{tabular}

Fonte: Limonad - Regiões Reticulares: Breves considerações para compreender as novas formas urbanas. 2004. 
Entre a $1^{\underline{a}}$ e $2^{\mathrm{a}}$ revoluções industriais, a indústria vai para a cidade e acelera 0 processo de urbanização. Na 3 a revolução industrial, com o modelo de acumulação flexível e o desenvolvimento do meio técnico, científico informacional, apontado por Milton Santos, diminuem os antagonismos entre campo e cidade.

Observa-se uma refuncionalização das formas, um redimensionamento das funções e uma ressignificação dos conteúdos. Rural ou urbano? O que se tem é um espaço social com diferentes atividades produtivas que se interpenetram, e que tornam indistintos os limiares das paisagens urbanas e rurais, das funções que se desenvolvem na cidade e no campo sem, contudo, haver uma homogeneização. (LIMONAD, 2010, p.174)

\subsection{Instrumentos de planejamento relacionados a áreas rurais}

As políticas de planejamento territorial compreendem políticas e instrumentos de legislação espacial, sejam urbanos, rurais ou ambientais. Ao levantar as políticas nacionais que se relacionam com as áreas rurais busca-se entender suas limitações e conflitos.

No Brasil, as sedes de município são consideradas cidades (decreto-lei 311 de 1938) e a delimitação do perímetro urbano-rural é definida por lei aprovada na Câmara de Vereadores. A implantação regular de parcelamento de imóvel rural (localizado em zona rural) para fins urbanos só é possível se lei municipal redefinir o seu zoneamento, transformando a zona rural ou parte dela (onde se encontra o imóvel) em zona urbana ou de expansão urbana.

Segundo Stifelman (2011), os loteamentos para fins rurais ou agrários obedecem a normas especiais editadas pela legislação agrária: Estatuto da Terra (Lei n. 4.504/64), seu regulamento (Decreto n.o 59.428/64), pela Lei n.o 5.868/72, pelo Decreto-Lei n. 58/37 e pela Instrução do INCRA n.ำ 17-b/80. 
Os parcelamentos urbanos em área rural são tratados pelo Instituto Nacional de Colonização e Reforma Agrária (INCRA) por meio da Instrução no 17-b, de 22/12/80. Nakano (2004) considera seu conteúdo genérico e insuficiente e questiona a responsabilidade exclusiva do INCRA em instruir sobre essa matéria. Aponta como alternativa para regulamentar a expansão urbana a delimitação de um novo perímetro urbano com a demarcação de zona de expansão urbana, nos termos da Lei Federal 6.766/79, que dispõe sobre o parcelamento do solo (NAKANO, 2004). Mas essa solução nem sempre é viável segundo o próprio autor, devido à ocorrência de vazios urbanos e à indução do surgimento de outras ocupações.

De acordo com a Constituição Federal de 1988, segundo artigo 22, a questão agrária é competência da União (INCRA) e, por outro lado, no artigo 182 tem-se que o município é responsável pela política urbana. Mas, no artigo 40 do Estatuto da Cidade (Lei № 10.257 de 2001) considera-se que o Plano Diretor deva abranger a totalidade do município.

Em estudo envolvendo a participação popular na elaboração de Planos Diretores de pequenos municípios, Passos (2010) aponta dificuldades de se trabalhar com comunidades rurais devido a limites na legislação. Segundo a lei Federal n 8.171 que trata de política agrária, a competência do município para definir políticas é reduzida no ambiente rural. O Plano Diretor não estaria elencado como instrumento da política agrícola e muito menos para definir a política de habitação rural.

Em publicação do Ministério das Cidades sobre Plano Diretor, no tocante a zonas rurais, sugere-se que o Plano Diretor identifique as áreas regularizáveis, ou parte delas, localizadas na zona rural, incluindo também estratégias e instrumentos para efetivar sua regularização. Para tanto é importante que seja feito o Zoneamento Ecológico Econômico da área rural. Não sendo possível, pode-se ainda detalhar um plano de regularização urbanística e fundiária em Lei complementar. Uma dificuldade de caracterizar as áreas rurais é que no Brasil ainda não existe um cadastro completo, atualizado e acessível dos imóveis rurais.

Concretamente, a porção rural do município é incluída no Plano Diretor por meio do macro-zoneamento rural. O princípio da democratização do acesso à terra 
rural deve orientar a demarcação dessas macro-zonas; assim como o princípio da sustentabilidade ambiental deve orientar a classificação das áreas de preservação permanente e de reserva legal (BRASIL, 2005).

O planejamento dos espaços urbanos e rurais acontece de forma não integrada. Por outro lado, a política de gestão ambiental envolve uma série de instrumentos que têm a pretensão de estar articulados em todas as esferas governamentais.

No âmbito da gestão ambiental as leis federais que disciplinam a proteção e o uso do meio ambiente, tanto para o campo quanto para a cidade são: o Código florestal (Lei 4771/65), a Resolução CONAMA (302, 303 e 369), a Lei da Política Nacional do Meio Ambiente, a Lei da Política Nacional dos Recursos Hídricos e a Lei do Sistema Nacional de Unidades de Conservação. A questão ambiental exige estudos e planejamento de espaços que extrapolam os limites municipais, como é o caso da gestão das águas.

A Constituição estabelece as águas como bens públicos, de domínio da União ou dos estados federados, passíveis de utilização mediante outorga de direitos de uso. A governabilidade e a governança relativas à gestão dos recursos hídricos dependem do grau de cooperação entre os diferentes níveis de Governo (a bacia hidrográfica constitui território comum à União, aos Estados e aos Municípios). A questão de coordenação envolve também a inserção dos municípios nas estratégias de gestão, uma vez que eles são responsáveis por variáveis decisivas como a legislação de uso e ocupação do solo, os serviços de saneamento, intervenções em drenagens e disposição de resíduos sólidos, dentre outras. (BRASIL, 2007).

No tocante aos instrumentos urbanos, para melhorar a efetividade dos processos de Planejamento e Gestão do município, destacando o Plano Diretor, Miranda afirma a necessidade de se estenderem, criativamente, às áreas de transição rural-urbana, os instrumentos urbanísticos recém conquistados com o Estatuto das Cidades (MIRANDA, 2009). No entanto há que se considerar que são instrumentos urbanos. Neste caso teriam que ser readequados à realidade rural. 
Em relação à sugestão de Miranda (2009), na adequação de instrumentos do Estatuto das Cidades para a realidade rural, Santoro (2012) sugere a Outorga Onerosa e afirma:

De fato, a Outorga Onerosa de Alteração de Uso, associada à elaboração dos planos de expansão urbana, parece ser um instrumento muito adequado para capturar a valorização imobiliária gerada pela transformação de terra rural em terra urbana. No entanto, o debate sobre este instrumento e sua aplicação ainda são embrionários no Brasil. (Santoro, 2010, p.424)

Miranda enfatiza ainda que o ordenamento do território é competência do município e deve ter, portanto, como finalidade o pleno cumprimento das funções sociais da cidade e da propriedade (urbana e rural) de modo que sejam enfrentadas as desigualdades sócio-territoriais. A autora aponta para o território rural algumas situações que deverão ser priorizadas: a) regulação do uso e ocupação do solo nos distritos e aglomerados situados na área rural; b) definição de zonas especiais de preservação ambiental, de interesse histórico e cultural; c) regulação das atividades de turismo e lazer; e d) controle ou regularização fundiária dos assentamentos irregulares, áreas ocupadas por população de baixa renda e dos loteamentos clandestinos.

Sintetizando as áreas do arcabouço jurídico que envolvem o tema temos:

$\checkmark$ A Legislação agrária - Estatuto da Terra (4504/64) e outras leis e decretos, elaborados, em sua maioria, antes da Constituição;

$\checkmark$ A Constituição Federal de 1988 - especificamente nos seguintes artigos:

- Art. 22 - onde enfatiza que a questão agrária é competência da União (INCRA);

- Art. 182 - ao apontar o município como o responsável pela política urbana;

$\checkmark$ A legislação urbana, principalmente o Estatuto da Cidade - 10257/2001 definindo:

- Que o Plano Diretor abrange a totalidade do município (Art.40);

- Instrumentos urbanísticos elaborados para o município, porém, com ênfase na área urbana; 
$\checkmark$ A legislação ambiental, com destaque para a Política Nacional do Meio Ambiente, abrangendo áreas urbanas e rurais;

\section{3.Áreas de interface urbano-rural}

As áreas de interface urbano-rural, ou rural-urbano, são denominadas de distintas formas e estudadas sob vários aspectos. Zona de transição, área periurbana, franja rururbana, franja rural-urbana, franja periurbana, periferia rururbana, espaço periurbano..., estes são alguns entre os vários termos utilizados para delimitar o espaço rural sobre o qual a cidade se expande.

Furtado (2011) faz uma análise de conceitos sobre o que ela denomina de áreas de interface periurbanas - abreviadas em AIPs. Distingue-os em conceitos tradicionais e recentes e elabora sua própria definição operacional ${ }^{13}$. A definição das AIPs segundo a abordagem de conceitos dessa autora é apontada no quadro 3.

Quadro 3: Caracterização de AIPs segundo tipos de conceitos

\begin{tabular}{|c|c|}
\hline Conceitos & Características gerais \\
\hline tradicionais & $\begin{array}{l}\text { as AIPs se configuram a partir das interações entre pessoas e meio ambiente } \\
\text { advindas de intervenções estatais, ações e práticas oriundas da ausência ou } \\
\text { fragilidade das políticas públicas de regulação ou provisão de serviços, e estratégias } \\
\text { cotidianas dos habitantes em termos de sobrevivência econômica, apropriação e } \\
\text { construção de espaços para moradia e outros usos. }\end{array}$ \\
\hline recentes & $\begin{array}{l}\text { espaços configurados por relações entre diferentes ecossistemas (rurais e urbanos) } \\
\text { e cuja produção esta associada e articulada a fenômenos muito mais amplos e que } \\
\text { extrapolam a sua materialidade, como as novas experiências de espaço-tempo, } \\
\text { decorrentes das dinâmicas e processos característicos de um mundo globalizado e } \\
\text { da intensa mobilidade que caracteriza esse começo de século. }\end{array}$ \\
\hline $\begin{array}{l}\text { Operacional } \\
\text { (definido pela } \\
\text { autora para } \\
\text { facilitar a } \\
\text { análise) }\end{array}$ & $\begin{array}{l}\text { As áreas de interface periurbana são aquelas que estão em torno das cidades, } \\
\text { principalmente as metrópoles, a uma distancia do centro urbano que permita o } \\
\text { deslocamento diário de pessoas e que se caracterizam por serem o lugar de uma } \\
\text { série de trocas, interações e fluxos específicos entre populações e ambiente urbanos } \\
\text { e rurais. Decorre daí, que subordinadas às dinâmicas espaciais desses sistemas, as } \\
\text { AIPs, constituem territorialidades transitórias e móveis, com variadas configurações. }\end{array}$ \\
\hline
\end{tabular}

${ }^{13}$ A definição operacional, sem procurar abarcar a totalidade de um tema, busca defini-lo segundo um determinado tempo, local e situação em que se pretende estudá-lo, conforme aponta a autora. 
Fonte: FURTADO, M. F. Áreas de Interface periurbana

Sparovek, Leonelli e Barreto constroem o conceito de Região de Entorno Imediato (REI) como o entorno do que é verdadeiramente rural ou verdadeiramente urbano, excluindo a vinculação direta com o urbano. Para esses três autores, reconhecer essa identidade própria e suas especificidades, ordenar o espaço com regras, mecanismos e incentivos adequados - que não sejam aqueles que só funcionam no urbano, nem pela lógica que só rege o rural - pode ser a chave para resgatar a dignidade e a função, para a sociedade desse espaço de transição (SPAROVEK et al, 2004).

Ao pesquisar áreas de transição rural-urbanas, Miranda (2009) estudou autores estrangeiros como Pryor, Kayser e Asencio, entre outros, e nacionais, como Correa e Juillard, levantando as dificuldades de caracterização desse território. Segundo a autora, o fato deve-se principalmente à dispersão, diversidade de processos, continuidades e descontinuidades e à sua baixa densidade (MIRANDA, 2009). A autora considera que a classificação de interfaces urbano-rurais desenvolvida por Asencio (2005) pode facilitar a elaboração de políticas territoriais mais integradas:

a) Urbano-periurbano, caracterizado por encontros dinâmicos e bidirecionais, com intercambio de informação e energias, com maior pressão do urbano.

b) Periurbano-rural, para as áreas que apresentam menor dinamismo, portanto menores pressões e conflitos de uso e ocupação do solo.

c) Urbano-rural, quando não se distingue uma franja periurbana, identifica-se claramente a passagem do solo urbano para o rural. (MIRANDA, 2009, p.165)

Com a denominação de interface periurbana, Adriana Allen faz uma abordagem ambiental e social dessas áreas por meio de projetos de pesquisas em vários países ${ }^{14}$. Aborda uma definição operacional de interface periurbana como sendo um sistema ecológico e socioeconômico distinto, em condições institucionais incertas (ALLEN, 2006, p. 374). Este conceito não se baseia em aspectos físicos, mas a uma alteração gradual entre os pólos urbano e rural. Em seus estudos há a preocupação de lidar com: os

14 Desde 1998 desenvolve pesquisas relacionadas a questão ambiental periurbana na Argentina, Brasil, Colômbia, Egito, Índia, México, Gana, Tanzânia e Venezuela. Pesquisadora do Development Planning Unity DPU (Unidade de Planejamento do Desenvolvimento) do University College London. 
problemas ambientais nos ambientes de moradia e trabalho da população pobre das áreas periurbanas e, a sustentabilidade dos recursos naturais, renováveis e nãorenováveis.

Limonad aponta que em decorrência da dispersão urbana há uma tendência a separação entre espaços de residência, consumo e trabalho materializados por meio de: (i) Condomínios fechados para classe média e alta próximos a vias de tráfego e em áreas rurais com amenidades ou vocação turística, (ii) Loteamentos residenciais em áreas rurais para trabalhadores urbanos nas áreas da franja metropolitana, (iii) Dispersão espacial de trabalhadores com a multiplicação de núcleos-dormitórios e proliferação de favelas, próximo a grandes eixos viários, em áreas economicamente dinâmicas, (iv) Concentração espacial de migrantes rurais formando periferias empobrecidas em áreas com baixa diversidade econômica e predomínio do setor primário. (LIMONAD, 2008, p.251)

Em relação às características das áreas de interface urbano-rural no Brasil (Furtado 2011) observa-se que são ocupadas por diversos grupos sociais, predominando as populações de mais baixa renda incluindo os excluídos dos sistemas econômicos, urbano e rural. Essa população tem menor acesso à infraestrutura e são mais expostos a riscos (contaminação de água, deslizamentos, poluição...). Muitos dos problemas existentes estão associados ao acesso e ao uso do solo. Há conflito sobre propriedade da terra, invasões, condomínios clandestinos e especuladores informais. Há sistemas de mercado formal e informal de terras. Há uma diversidade de usos onde se destacam: o habitacional, industrial, grandes infraestruturas urbanas, agricultura, pecuária, mineração... Usos que ocorrem em áreas de relevância ambiental (como mananciais hídricos e remanescentes de florestas).

Sposito (2010) aponta que as lógicas de expansão urbana respondem aos interesses dos proprietários de terras, incorporadores e corretores sem considerar questões ambientais, patrimoniais e culturais. Nessa lógica aponta tendências que se articulam:

a) aumento do estoque de terras loteadas como urbanas, não ocupadas, já que a expansão territorial é maior que o crescimento demográfico; b) aumento dos preços dos imóveis, tanto porque a expansão territorial em 
descontínuo valoriza os imóveis, que estão relativamente mais próximos das áreas melhor equipadas das cidades, quanto pelo fato de que os novos imóveis agregam novos produtos e se tornam comparativamente "melhores"; c) imóveis de médio e alto padrão tendem a ser vendidos para pessoas que já eram proprietárias de imóveis, em função dessa diferença de "qualidade" oferecida e não mais, como ocorria anteriormente, quando eram adquiridos por quem não era proprietário ainda; d) ampliação do contingente de pessoas que estão fora das possibilidades de solucionar $o$ problema habitacional no âmbito do mercado. (SPOSITO, 2010, p.133)

Embora apresentem conflitos nos tipos de uso, altas taxas de crescimento demográfico e expansão horizontal, geralmente não há regulação sobre sua ocupação. A falta de regulação urbanística 'deixa' para o mercado a definição do acesso ao solo urbano. Como consequência, tem-se a ocupação pela população de baixa renda, de áreas ambientalmente frágeis (encostas, proximidade de rios, áreas de proteção ambiental...) e próximas a atividades poluidoras e insalubres (aterros sanitários, tratamento de esgoto, mineração...), onde os terrenos são mais baratos e sem resistências políticas.

Conforme aponta Furtado (2011), geralmente são consideradas como áreas de expansão urbana, com utilidade para o urbano, sem uma clara compreensão do seu significado. Um consenso observado nos estudos de áreas de transição é a dificuldade de uma abordagem prática, de políticas públicas adequadas a essas áreas pelo planejamento urbano no Brasil.

\subsection{A expansão urbana sobre o rural}

Nas pesquisas de assuntos relacionados à expansão urbana e transformação de áreas rurais em urbanas encontram-se abordagens envolvendo: dificuldade de controlar a expansão urbana, periferização da população de baixa renda, implantação de loteamentos e conjuntos habitacionais, atuações dos agentes envolvidos com a transformação do solo, valorização do solo, novos arranjos sócioespaciais, entre outros, além de debates conceituais sobre campo e cidade. 
Miranda (2008) realizou um levantamento de trabalhos relativos a expansão urbana e impactos da urbanização, contextualizados por períodos históricos. O Quadro 4 sintetiza o levantamento feito pela autora:

Quadro 4: histórico de pesquisas relacionadas à expansão do urbano sobre o rural

\begin{tabular}{|c|c|c|}
\hline Período & Contexto & Autores \\
\hline $\begin{array}{l}\text { Da década de } \\
1940 \text { à década } \\
\text { de } 1960\end{array}$ & $\begin{array}{l}\text { A urbanização brasileira expandia-se por meio de } \\
\text { loteamentos na periferia das capitais, impulsionados } \\
\text { pela implantação das Rodovias da integração } \\
\text { nacional. }\end{array}$ & $\begin{array}{l}\text { Deffontaines (1944); } \\
\text { Bernardes (1957); Sagadas } \\
\text { (1965); Ab'saber e } \\
\text { Bernades (1958); Maciel e } \\
\text { Albani (1965); Costa } \\
\text { (1960) }\end{array}$ \\
\hline $\begin{array}{l}\text { Da década de } \\
1970 \text { aos anos } \\
1990\end{array}$ & $\begin{array}{l}\text { Intenso êxodo rural e crescente metropolização das } \\
\text { principais capitais. No processo de transformações } \\
\text { de rural em urbano - a partir da expansão residencial } \\
\text { na periferia, conformando áreas populares e de } \\
\text { status - foram analisados condomínios fechados, } \\
\text { loteamentos populares e favelas. Também há } \\
\text { análises da segunda residência, registrando o } \\
\text { processo de dispersão e reprodução espacial. }\end{array}$ & $\begin{array}{l}\text { Cunha (1975); Corrêa } \\
\text { (1979); Azevedo (1982); } \\
\text { Davidovich (1983) (1987); } \\
\text { Zanchetti e Pontual } \\
\text { (1991); Silva (1992); Carlo } \\
\text { (1994). 2a residência: } \\
\text { Seabra (1979) e Coelho } \\
\text { (1986). }\end{array}$ \\
\hline \multirow{5}{*}{$\begin{array}{l}\text { Da década de } \\
1990 \text { ao período } \\
\text { recente } \\
\text { (Os impactos da } \\
\text { urbanização } \\
\text { sobre o meio } \\
\text { rural geram } \\
\text { mais tensões e } \\
\text { oportunidades e } \\
\text { conseqüentes } \\
\text { interpretações) }\end{array}$} & $\begin{array}{l}\text { As relações rural-urbanas brasileiras confirmavam a } \\
\text { ideia de um continuum. }\end{array}$ & Santos (1993) \\
\hline & $\begin{array}{l}\text { Sistematizaram o que seria o 'novo rural' relacionado } \\
\text { com a penetração da globalização no território rural, } \\
\text { o fortalecimento da idéia de conservação da } \\
\text { natureza, e a permanência da agricultura de } \\
\text { subsistência. }\end{array}$ & $\begin{array}{l}\text { Graziano da Silva (1997) e } \\
\text { Veiga (2006) }\end{array}$ \\
\hline & $\begin{array}{l}\text { Novas tipologias habitacionais nas periferias (ex. } \\
\text { Alphaville) caracterizadas pela exclusividade e a } \\
\text { mercantilização das amenidades ambientais. }\end{array}$ & $\begin{array}{l}\text { Souza (2000): } \\
\text { 'suburbanização } \\
\text { ampliada'. }\end{array}$ \\
\hline & $\begin{array}{l}\text { Especularam sobre o nascimento de um novo } \\
\text { paradigma da ação imobiliária sobre a cidade }\end{array}$ & Cardoso e Ribeiro (1994) \\
\hline & $\begin{array}{l}\text { Reforçaram a necessidade de fortalecer os estudos } \\
\text { intraurbanos metropolitanos. }\end{array}$ & $\begin{array}{l}\text { Vilaça (2001) e Lago } \\
(2000)\end{array}$ \\
\hline
\end{tabular}

Adaptado de: MIRANDA, L. I. B. Produção do espaço e planejamento em áreas de transição rural-urbana: o caso da Região Metropolitana do Recife - PE. 2008. Tese

Sem a pretensão de abarcar a atual produção literária ligada ao tema, listamos aqui alguns estudos recentes sobre a questão no Brasil e na América Latina.

Sposito e Whitacker sintetizaram em livro, o resultado de um Colóquio sobre 'Cidade e campo: relações e contradições entre urbano e rural' ${ }^{15}$. Embora o foco dos pesquisadores seja cidades médias e pequenas, o tema é de relevância num mundo em transformação rápida, "em que os limites e distinções entre a cidade e o campo se esvaecem, à medida que novas formas de assentamento humano são produzidas e que

${ }^{15}$ Colóquio realizado pelo grupo de pesquisa "Produção do espaço e redefinições regionais" (GASPERR) da Universidade Estadual Paulista (UNESP) 
as relações e as articulações entre o urbano e o rural se acentuam." (SPOSITO \& WHITACKER, 2010, p.9)

Ainda no campo da análise da relação rural-urbano, Saquet, Suzuki e Marafon, organizaram livro sobre temas debatidos em encontros de geografia agrária e no "I Simpósio Nacional o Rural e o Urbano no Brasil.." ${ }^{16}$ No âmbito da geografia agrária, os textos revelam a diversidade que marca o momento atual do pensamento acerca do campo e da cidade em situações brasileiras e latino-americanas. (SAQUET, SUZUKI, MARAFON. 2011, p.11)

Randolph e Southern organizaram livro sobre estudos que abordam a 'Expansão metropolitana e transformação das interfaces entre cidade, campo e região na América Latina'. Segundo os organizadores: "O que se busca são novos caminhos metodológicos para melhor esclarecer como se dão as relações entre metropolização e os processos de reestruturação sócio-territorial em áreas Peri-metropolitanas". (RANDHOLPH \& SOUTHERN, 2011, p.15)

Conforme o levantamento de Miranda, os enfoques dos estudos sobre os processos de expansão da urbanização variam segundo a realidade histórica de cada período. Nos estudos recentes, conforme a atualidade das publicações citadas, há uma busca por se entender as relações contemporâneas das interações urbano-rural sob vários olhares, seja por quem estuda o campo, as pequenas e médias cidades ou as grandes metrópoles.

\subsection{Apontamentos sobre agentes e momento histórico}

Ao tentar entender o que ocorre nessas áreas de expansão urbana, onde novas realidades/situações estão se configurando, busca-se verificar sua inserção no

\footnotetext{
${ }^{16}$ Realizado em 8 e 9 de dezembro de 2006. Local: Departamento de Geografia/FFLCH/USP, em copromoção com o Programa de Pós-Graduação em Geografia da UFRGS.
} 
contexto capitalista e na propalada globalização, além de formas teóricas de se discutir urbanização e as relações sociais locais.

Harvey (2006) aponta que o poder de organizar o espaço se origina em um conjunto complexo de forças mobilizado por diversos agentes sociais. Para ele a urbanização deveria ser considerada um:

[...] processo social, espacialmente fundamentado, no qual um amplo leque de atores, com objetivos e compromissos diversos, interagem por meio de uma configuração específica de práticas espaciais entrelaçadas. Em uma sociedade vinculada por classes, como a sociedade capitalista, essas praticas espaciais adquirem um conteúdo de classe definido, o que não quer dizer que todas as práticas espaciais possam ser assim interpretadas. (HARVEY, 2006, p. 170).

No tocante à atuação do Estado, Corrêa aponta que o Estado Capitalista desempenha múltiplos papéis em relação à produção do espaço. Essa multiplicidade decorre do fato de o Estado constituir uma arena na qual diferentes interesses $e$ conflitos se enfrentam. (CORRÊA, 2011, p. 45). Nas áreas de estudo, o Estado, assume o papel de agente imobiliário ao criar uma empresa como a Terracap para gerenciar a venda das terras. Ao ampliar as áreas urbanas nos Planos de Ordenamento Territorial e legalizar loteamentos irregulares o Estado local segue a lógica apontada por Lojkine:

Na medida em que a planificação estatal aparece subordinada não a uma lógica de controle racional, pela sociedade, de seu desenvolvimento coletivo mas sim à lógica de acumulação do capital privado, a planificação assim como o conjunto da política estatal agem menos como instrumento de regulação do que como revelador de uma sociedade retalhada pelo conflito de classes antagônicas. (LOJKINE, 1981, p.321)

Como se observa nas discussões conceituais da relação cidade-campo e dos espaços de transição, para entender o que ocorre em determinado local, é importante entender seu contexto num período histórico. Entender também que o que ocorre num local pode estar relacionado a fatores distantes. Neste sentido, segundo Santos (2002), no tocante à globalização, não existe um espaço global, mas, apenas, espaços da globalização. O autor aponta que a ordem global busca impor, a todos os lugares, uma única racionalidade. E os lugares respondem ao Mundo segundo os diversos modos de sua própria racionalidade. (SANTOS, 2002, p.338) 
Conforme aponta Sposito (2010), observa-se novas práticas socioespaciais, novas formas de habitat e de interação social, novos conteúdos culturais que diferentes sujeitos sociais atribuem aos espaços em que vivem, independentemente de suas qualificações, como urbanos ou rurais (SPOSITO, 2010, p.129). Além da atuação do Estado e dos incorporadores imobiliários interessa-nos aqui a atuação dos demais sujeitos sociais, busca-se tentar entender o que vem ocorrendo no sentido de resistência a esse processo de expansão urbana controlado por especuladores imobiliários:

\begin{abstract}
Por enquanto, o lugar - não importa sua dimensão - é, espontaneamente, a sede da resistência, às vezes involuntária, da sociedade civil, mas é possível pensar em elevar esse movimento a desígnios mais amplos e escalas mais altas. Para isso é indispensável insistir na necessidade de um conhecimento sistemático da realidade, mediante o tratamento analítico do território, interrogando-o a propósito de sua própria constituição no momento histórico atual. (SANTOS, 2002, p.259)
\end{abstract}

Outro ponto de análise ao verificar o processo de expansão urbana é a discussão sobre a urbanização da sociedade. Para tanto busca-se aqui as conceituações de Henry Lefebvre e as considerações de pesquisadores utilizando-o como referência.

Ao se falar do direito à cidade, Lefebvre fala de um direito à vida urbana, onde o urbano é o lugar do encontro, prioridade do valor de uso sobre o valor de troca (Lefebvre, 2008). Conforme aponta Monte-Mór, Lefebvre questiona a fragmentação funcional da cidade com:

[...] a concepção da habitação separada do espaço do poder, separada do espaço do lazer e da cultura, dos centros históricos e da centralidade urbana em si mesma e tratando a questão da habitação como uma função humana e social contida nela mesma e com lógica própria, justificando a expulsão dos pobres e proletários do centro do poder para jogá-los para as periferias. (MONTE-MÓR, 2011, p.206).

$\mathrm{Na}$ atualidade, é considerado que esse direito envolve também ter acesso à serviços, equipamentos e infraestrutura geralmente relacionados às cidades (embora o histórico das cidades brasileiras seja de carência desses itens).

Lefebvre fala ainda de um processo de urbanização da sociedade onde se conquistaria a sociedade urbana por meio de uma revolução urbana. A sociedade urbana é uma potencialidade que pode vir a se realizar. Segundo Monte-Mór (2011), a 
revolução urbana se daria a partir da luta centrada na vida cotidiana, na qualidade de vida, na cultura. Esta luta centrada na reprodução coletiva tem como parceira central a preocupação e a ação política voltada para a questão ecológica e ambiental, referencial das questões ligadas à reprodução. (MONTE-MÓR, 2011, p. 215)

Também referenciando Lefebvre, Endlich (2009) assinala que a sociedade urbana deveria representar a apropriação do tempo e do espaço para o ser humano, como sendo uma modalidade superior de liberdade. A apropriação, assim compreendida, significa tornar próprio e adequado pelo uso, sem que isso represente posse e sem que se paute pela ideia de propriedade. Apropriação significaria mais do que simplesmente habitar, ela faz parte da recuperação da autonomia.

O desafio para a sociedade é conquistar urbanidade em meio a esse intenso e contraditório processo de urbanização, urbanidade compreendida como resultado de conquistas políticas advindas da vida urbana, bem como o acesso e intercâmbio de manifestações culturais diversas. (ENDLICH, 2009, p.36).

Entendemos que a busca de uma sociedade urbana compreende busca de qualidade de vida, de serviços, de cultura, etc., independente de ser área urbana ou rural.

\subsection{Elementos históricos da ocupação espacial brasileira}

A análise histórica aborda, no contexto nacional, o processo de ocupação do território brasileiro e as questões sociais e econômicas presentes. No intuito de tratar da pressão metropolitana sobre áreas rurais, busca-se entender as características históricas da urbanização brasileira e as alterações ocorridas no campo no país.

Durante o período colonial a economia do país era essencialmente agrícola. A base da economia desenvolvia-se por meio da exploração dos recursos naturais mais rentáveis para Portugal no período, sendo guiado pelas demandas dos mercados europeus. 
Da exploração inicial de pau-brasil no litoral, seguiram-se ciclos produtivos em outras regiões brasileiras. Compreendem a cana de açúcar no nordeste (entre séc. XVI e XIX), a mineração em Minas Gerais, Goiás e Mato Grosso, (séc. XVII e fins do XVIII), a pecuária no sul (segunda metade do séc. XVIII e início do séc. XX), a borracha e o algodão no norte (século XIX e início XX) e o café em São Paulo (séculos XIX e XX) ${ }^{17}$. A constituição e a ocupação do território brasileiro foram se configurando pelas atividades econômicas predominantes.

Da mesma forma, a urbanização no período colonial se deu conforme uma agenda política e econômica da metrópole. As cidades foram criadas para facilitar o escoamento da produção agrícola para os mercados europeus. Eram cidades com funções administrativas e burocráticas. Neste sentido as primeiras cidades eram localizadas no litoral ou em localidades próximas:

Nos dois primeiros séculos da colonização, a razão econômica principal de ocupação da colônia era a produção para exportação do açúcar de cana, atividade que se exercia toda no campo. Às cidades, geralmente situadas às margens de rios, baías e no litoral, cabia armazenar o produto e exportá-lo para a Europa. A população da colônia era, então, predominantemente rural, mas os senhores de engenho e seus familiares residiam, alternadamente, na cidade e no campo. (GOMES, 2008, p.86)

Nestes primeiros séculos iniciou-se uma estruturação da formação social brasileira como uma sociedade dividida em classes e escravocrata; o que pode ser verificado nas fazendas de cana do nordeste nesse período:

[...] a casa-grande, a capela, a fábrica e a senzala, materializam e retratam, pela sua arquitetura, uma verdadeira síntese da sociedade brasileira de então, mas que pode ser considerada, ainda hoje, como o insuperável arquétipo das contradições sociais do Brasil. (BICCA, 2008, p.13)

O papel do Brasil no mercado externo ${ }^{18}$ era como fornecedor de produtos primários, a partir da produção em larga escala via monocultura e com mão de obra escrava. Latifúndios e monocultura marcam, desde o princípio, o processo de

17 A classificação apresentada segue a época que as atividades foram largamente predominantes, conforme texto de Briane e Paulo Bicca no livro Arquitetura na Formação do Brasil, 2008.

${ }^{18} \mathrm{O}$ mercado externo de que se trata aqui corresponde ao mercado externo de Portugal, uma vez que o Brasil era apenas uma colônia. Papel desempenhado ainda nos dias atuais: dependência econômica brasileira que determina a pauta de produtos para exportação, ou seja, dependência brasileira em relação à economia internacional. 
ocupação das áreas rurais brasileiras. A concentração fundiária - que ainda hoje é uma marca do campo brasileiro - iniciou-se com o instrumento colonial das sesmarias ${ }^{19}$ e intensificou-se pela lei de terras de $1850^{20}$ (Alentejano 2012).

A expansão territorial adentrando no continente só foi ocorrer em função da pecuária e da mineração. A mineração ativou a circulação de mercadorias e pessoas entre as diferentes regiões. Localizados ao longo de vias fluviais e terrestres, muitos dos núcleos urbanos serviam de entreposto comercial e local de pouso aos viajantes. Em Minas Gerais cidades se formaram a partir dos pontos de mineração:

As características peculiares da exploração do ouro aluvional - minerado nos rios e riachos - favoreceram o assentamento das populações mineradoras em multiplicados núcleos urbanos, desenvolvidos a partir dos acampamentos primitivos que se formavam nas margens dos riachos auríferos e dos pontos de venda onde ia se instalando um comércio incipiente. O traçado pitoresco desses pequenos povoados, com seus arruamentos espontâneos, acompanhando o leito dos rios e subindo pelas encostas, seria uma das contribuições mais características do Ciclo da Mineração à história da arquitetura e do urbanismo no Brasil. (OLIVEIRA, 2008, p.131).

Milton Santos considera que o período colonial tratava mais da geração de cidades do que mesmo um processo de urbanização. Num país tão extenso, subordinado a uma economia natural, as relações entre lugares eram fracas e inconstantes. Mas, mesmo assim, a expansão da agricultura comercial e a exploração mineral foram a base de um povoamento e a criação de riquezas, redundando na ampliação da vida de relações e no surgimento de cidades no litoral e no interior. (SANTOS, 2009, p.22) E ainda, segundo o autor:

O Brasil foi, durante muitos séculos, um grande arquipélago, formado por subespaços que evoluíam segundo lógicas próprias, ditadas em grande parte por suas relações com o mundo exterior. Havia, sem dúvida, para cada um desses subespaços, pólos dinâmicos internos. Estes, porém, tinham entre si escassa relação, não sendo interdependentes. (SANTOS, 2009, p.29)

Essa situação começa a mudar no século XIX com a produção do café em São Paulo que passa a se tornar o pólo dinâmico do sul e sudeste, potencializando

\footnotetext{
${ }^{19}$ Dava aos senhores de terras o direito de exploração econômica das mesmas e poder político de controle sobre o território. (Alentejano, 2012)

${ }^{20}$ A Lei de Terras de 1850 transformou a terra em mercadoria e assegurou a continuidade do monopólio privado, ainda que sob outras bases jurídicas. (Alentejano, 2012)
} 
mudanças de ordem material e social. Segundo Milton Santos (2009), a implantação de estradas de ferro, melhoria dos portos e criação de meios de comunicação atribuem maior fluidez a essas regiões. Fluidez efetivada, sob a pressão do comércio internacional, por novas relações de produção e trabalho. É com base nessa nova dinâmica que o processo de industrialização se desenvolve, porém de forma desigual no território, com predomínio da região sudeste.

A partir de 1930 têm-se a implantação de indústrias de base, sobretudo estatais. O Estado passa a investir em infraestrutura para o desenvolvimento industrial visando à substituição de importações. Observa-se uma crescente articulação comercial entre as regiões e fortalecimento do mercado interno. Com a industrialização, há um grande desenvolvimento das forças produtivas, diversificação, assalariamento crescente e modernização da sociedade (Maricato, 2001, p.18). Neste período inicia-se a ampliação da conformação da rede urbana brasileira.

Embora em 1940, o crescimento da população urbana chegue a superar o crescimento da população rural, a maior parte da população ainda vivia em zonas rurais. A principal contribuição ao Produto Interno Bruto vinha do setor primário que empregava a maior parcela da população ativa.

Mas, conforme aponta Milton Santos, à partir dos anos 1940 e 1950 a lógica da industrialização prevalece. A industrialização é apontada pelo autor com uma significação mais ampla:

[..] como processo social complexo, que tanto inclui a formação de um mercado nacional, quanto os esforços de equipamento do território para torná-lo integrado, como a expansão do consumo em formas diversas, o que impulsiona a vida de relações (leia-se terceirização) e ativa o próprio processo de urbanização. (SANTOS, 2009, p. 30)

Após o fim da II Guerra Mundial, a internacionalização da economia brasileira e a penetração de capitais multinacionais consolidam o Brasil como país urbanoindustrial inserido no processo de divisão internacional do trabalho. Na década de 1950 o país passa a produzir bens duráveis e até mesmo bens de produção. A introdução das indústrias de bens de consumo dinamiza o papel das cidades, a demanda crescente de mão de obra, e os fluxos expressivos no território. Se verifica, 
segundo Maricato (2001), um crescente controle do capital internacional, cujo centro das decisões é cada vez mais externo ao país e distanciado das necessidades internas.

Em meados da década de 1960, com a implantação do regime militar, ocorre um alargamento da fronteira agrícola e uma preocupação geopolítica de controle do Território Nacional. Brasília, a nova Capital, exerce importante papel neste projeto de integração nacional; principalmente no Centro Oeste, cumprindo o papel de pólo de desenvolvimento regional.

A migração rural urbana se intensifica em virtude da mecanização ${ }^{21}$ do campo e o aumento da concentração da propriedade. Segundo Milton Santos, semelhante estrutura da propriedade favorece ao mesmo tempo a persistência da pobreza e o abandono do campo. (Santos, 2001, p.41) O êxodo rural não ocorre devido a existência de empregos na cidade, mas, devido a esta estrutura agrária característica da maior parte do território brasileiro.

\begin{abstract}
Iniciada com o instrumento colonial das sesmarias - que dava aos senhores de terras o direito de exploração econômica das mesmas e poder político de controle sobre o território - e intensificada pela Lei de Terras de 1850 - que transformou a terra em mercadoria e assegurou a continuidade do monopólio privado, ainda que sob outras bases jurídicas -, a concentração fundiária segue sendo uma marca do campo brasileiro. (ALENTEJANO, 2012, p.353)
\end{abstract}

Milton Santos também aponta para o desenvolvimento do capitalismo agrário com a modernização da agricultura, expansão das fronteiras agrícolas e intensificação da mão de obra de trabalhadores volantes, os bóias-frias (Santos, 2001, p.49). Estes trabalham nos campos, mas residem nas periferias das cidades. Nessa conjuntura, nos anos 1970, a população urbana ultrapassa a rural. Devido ao êxodo rural, seu ritmo de crescimento torna-se mais acelerado que o da população total do país.

A população urbana cresce de forma acelerada e se concentra nas áreas metropolitanas. A implantação de infraestrutura não consegue acompanhar a demanda, embora as atividades ligadas à construção civil ajudassem a manter o crescimento do PIB na segunda metade da década de 1970. De 1940 a 1980, o PIB

\footnotetext{
${ }^{21}$ Também conhecida como modernização da agricultura, onde o Estado viabiliza a produção de máquinas, insumos e pesquisa direcionados à produção em larga escala mantendo a conformação monocultura/latifúndio.
} 
brasileiro cresceu a índices superiores a 7\% ao ano, um dos maiores do mundo no período. Por outro lado, a riqueza gerada nesse processo permaneceu concentrada. (Maricato, 2001)

A partir dos anos 1980 as cidades de porte médio, com população entre 100 mil e 500 mil habitantes crescem a taxas maiores do que as das metrópoles. Milton Santos as qualifica como lócus do trabalho intelectual, mais qualificado; sendo lugar dos fluxos crescentes das classes médias enquanto os fluxos de pobres se dão para as grandes cidades. (Santos, 1994, p.123). Aumenta também o número de cidades locais e centros regionais. As metrópoles regionais intensificam suas relações com o restante do país e suas áreas metropolitanas intensificam atividades e processos econômicos e sociais em sua região de influência. Ao mesmo tempo observa-se que o crescimento das periferias das regiões metropolitanas é maior que o do núcleo central.

Nas décadas de 1980 e 1990 o Brasil sofre o impacto da reestruturação produtiva internacional por meio de ajustes neoliberais: estado mínimo e prioridade do mercado em detrimento das necessidades da população. Segundo Maricato (2011), na década de 1980, o investimento em habitação social foi quase nulo. A taxa de crescimento da população que morava nas favelas triplicou em relação à população urbana em seu conjunto e, na década seguinte duplicou.

Neste período a concentração de renda se aprofunda. Em 1995, 50\% dos mais pobres detinham $13,3 \%$ da renda (era $14,5 \%$ em 1981) enquanto que o $1 \%$ mais rico detinha $14,4 \%$ da renda (era 13,4\% em 1981). Aumentam também o desemprego, as relações de trabalho informal e a pobreza nas áreas urbanas. Maricato (2001) aponta o aumento da violência como um dos indicadores mais expressivos da piora das condições de vida urbana.

Os dados do índice de Gini apontados no gráfico da fig.1 ilustram bem as fortes desigualdades ocorridas nas décadas de 1970, 1980 e 1990, num período de intensa urbanização e acentuada concentração de renda. 


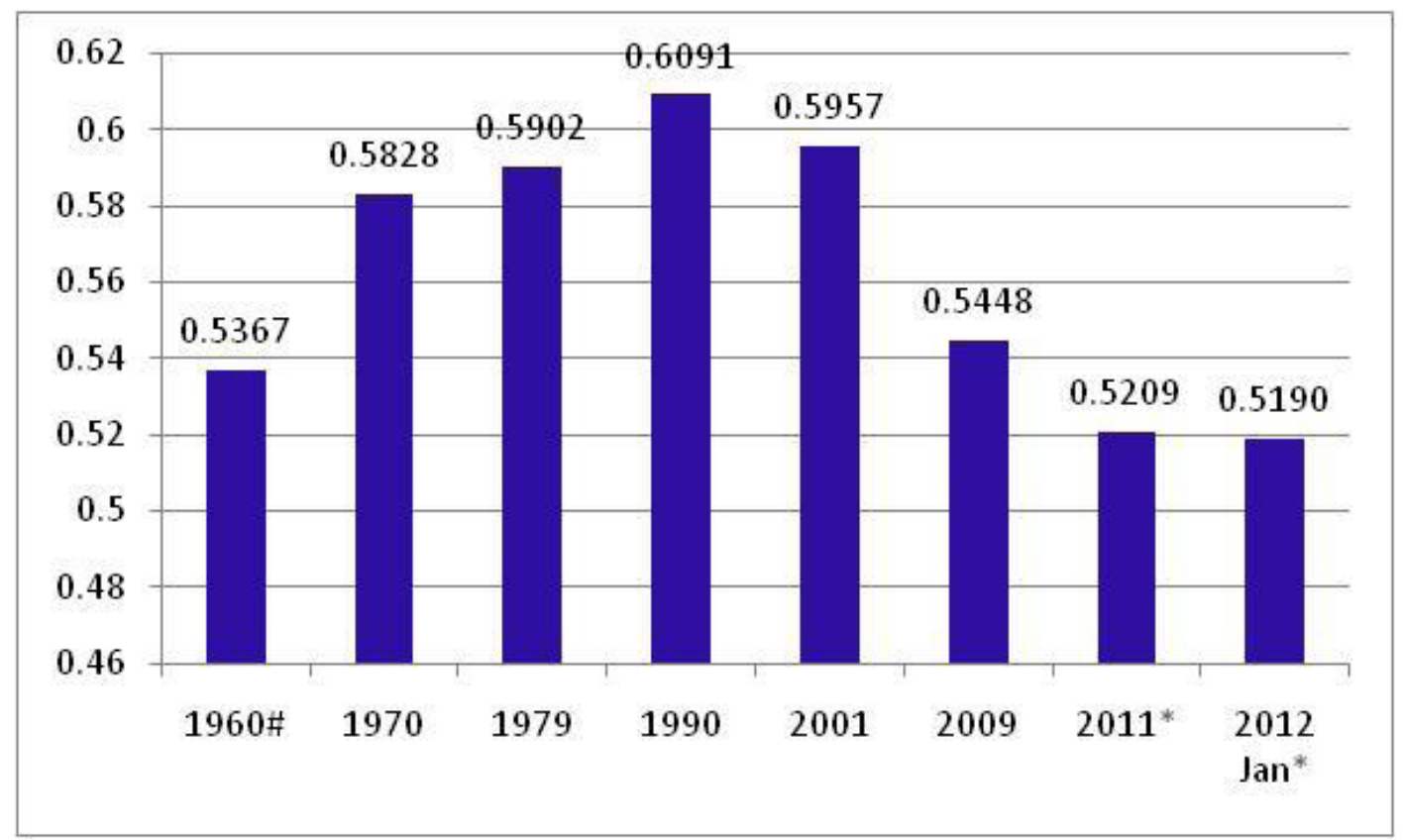

Figura 1: ìndice de Gini. Fonte: CPS/FGV a partir dos microdados da PNAD, PME e Censo / IBGE e Langoni 1973

Observa-se um inchaço das cidades que não desenvolveram sua capacidade produtiva para atender as demandas de emprego da população imigrante. Esta, por sua vez, busca mecanismos de trabalho no terciário informal. A população que migra para os grandes centros tem como solução de moradia, favelas e loteamentos irregulares nas periferias, sem infraestrutura e geralmente em áreas de frágil equilíbrio ambiental.

Mas, conforme debate Maricato, a situação urbana brasileira tem suas raízes em cinco séculos de formação da sociedade brasileira, em especial a partir da privatização da terra (1850) e da emergência do trabalho livre (1888). (MARICATO, 2001, p.23). No processo histórico de urbanização brasileira, as condições de trabalho e moradia da maioria da população estão relacionadas com o fim da escravidão e a propriedade privada, onde o trabalhador livre, sem terra para cultivar, começa a ocupar cortiços e arredores das cidades.

[...] o crescimento urbano sempre se deu com exclusão social, desde a emergência do trabalhador livre na sociedade brasileira, que é quando as cidades tendem a ganhar nova dimensão e tem início o problema da habitação. Quando o trabalho se torna mercadoria, a reprodução do trabalhador deveria, supostamente, se dar pelo mercado. Mas isso não aconteceu no começo do século XX como não acontece até o seu final. (MARICATO, 2001, p.22) 
Retornando a Figura 1, a melhora nos índices de desigualdade nesse início de século se relaciona a atuações governamentais:

As políticas sociais promovidas pelo governo Lula (bolsa família, aumento real do salário mínimo e crédito consignado) somadas ao aumento do crescimento econômico, no período de 2003/2010, lograram melhorias na base da pirâmide social. No entanto, os problemas urbanos não mostraram alívio. (MARICATO, 2011, p.150)

A questão da terra continua a se situar no centro do conflito social: ela alimenta a profunda desigualdade - ainda que haja a recente pequena distribuição de renda - e a tradicional relação entre propriedade, poder político e poder econômico. (MARICATO, 2011, p.186). No campo ela tem forte ligação com o avanço do agronegócio. Nas cidades, a dificuldade de acesso à terra regular para habitação é uma das maiores responsáveis pelo crescimento de favelas e loteamentos ilegais nas periferias. Outra questão é a confusão no sistema de registro de terras, tanto no campo quanto na cidade, dificultando sua legalização. O mercado residencial legal no Brasil atende perto de $30 \%$ da população.

Sem alternativa legal, grande parte da população urbana invade terra para morar. As terras que não interessam ao mercado imobiliário, ocupadas pela população de baixa renda são áreas de ecossistema frágil onde incide a legislação de proteção ambiental. (MARICATO, 2011, p.187)

Fazendo um parêntesis em relação aos conflitos e processos de luta: embora não descritos aqui, ocorreram ao longo de todo o processo de ocupação do território brasileiro. Tanto no campo quanto na cidade, a questão fundiária sempre esteve presente. Miranda aponta diferenças estruturantes nestes dois processos: a luta pela reforma agrária, mais ligada a mudanças estruturais, apontou para a desconcentração de terra necessária à desconcentração dos meios de produção e perspectivas econômicas mais solidárias; já a reforma urbana, também apontou para a questão fundiária, mas acabou dando ênfase à reprodução social dos segmentos marginalizados e excluídos das cidades. Segundo a autora, esses projetos acabaram não construindo pontes para diálogos:

Se houve equívocos em relação a essas estratégias, ou pelo menos à falta de esforços para aproximações desejáveis - como faces de uma mesma moeda, isso fica evidente quando em alguns territórios as questões se misturam mais claramente: como é o caso das áreas de transição rural-urbana. Vale ressaltar que, o distanciamento dessas lutas interessou e interessa a todos 
que concentraram poder político, terra, renda, riquezas, meios de produção entre outros, e eles souberam influenciar marcos regulatórios, políticas públicas e a opinião pública. (MIRANDA, 2009, p.19)

Em relação à economia, o processo de globalização avança nas atuais relações internacionais. Os conglomerados transnacionais associados ao capital financeiro concentram poder e decisão e há uma desconcentração da produção. Seu impacto no território brasileiro compreende a anexação de novas regiões à dinâmica do agronegócio, reajustando os movimentos migratórios, reorientando a direção do crescimento urbano, determinando o desmatamento do cerrado e da Amazônia e a expansão da monocultura. (Maricato, 2011).

No processo de urbanização contemporânea neste início do século XXI, observamos que a urbanização se estende pelo território nacional e se impõe no espaço brasileiro para além dos limites das cidades. Os espaços rurais e regionais se integram ao contexto urbano-industrial apresentando uma gama variada de interações. Neste novo processo de urbanização cada vez mais diversificado os problemas também se diversificam e intensificam se somando aos já existentes.

Na busca de uma síntese do processo de urbanização brasileiro, podemos considerar que, de uma fraca urbanização no período colonial (próxima ao litoral e ligada aos interesses da metrópole), com o advento da industrialização e o êxodo rural, o país passa a ter uma população eminentemente urbana no início do século XXI. Porém algumas questões permanecem como desafios a superar. De uma economia agroexportadora para uma economia industrial, o sistema produtivo nacional sempre esteve subordinado a interesses externos. A atuação governamental prioriza interesses econômicos em detrimento da maioria da população. A concentração da propriedade permanece tanto no campo como na cidade. Apesar de melhorias oriundas de programas sociais da última década, as desigualdades sociais persistem. 


\subsection{Trabalhos de referência sobre uso e ocupação do solo e áreas rurais no DF}

Na gama de estudos sobre o Distrito Federal, busca-se fazer um apanhado de pesquisas e informações que se relacionam com uso e ocupação do solo e áreas rurais por meio de diferentes abordagens. Longe de abarcar toda a literatura produzida, são destacados pesquisadores cujos estudos dialogam com aspectos da tese ou serviram de referência para sua elaboração.

Nos seus estudos sobre a região do Planalto Central, o historiador Paulo Bertran aborda uso e ocupação do solo antes da implantação do DF. Em seu livro: 'História da terra e do homem no Planalto Central: eco-história do Distrito Federal' (2011), o autor traz elementos arqueológicos da ocupação na região e sua relação com o ambiente natural na formação do território. Em seus escritos, ao analisar a ocupação sócio-espacial, o autor cria uma classificação para o homem local:

A história do Planalto Central é interminável: pelas dimensões geológicas
remonta, no mínimo, a 1 bilhão de anos. Pela escala arqueológica, da
povoação indígena, pode retroceder a 12 mil anos ou muito mais. E pela sua
colonização gregária, por colonizadores de extração luso-brasileiro-africana,
teria no mínimo dois séculos e meio, fazendo aqui proliferar a civilização,
ecologicamente diferenciada, do Homo cerratensis. (BERTRAN, 2011, p.252)

Além das análises de Bertran, Barbo (2010) estuda mapas e antigos caminhos coloniais e faz um apanhado da arquitetura rural histórica anterior à Capital. Os Relatórios Cruls e Belcher, publicados pela CODEPLAN (1995), apresentam informações relevantes sobre a região para definição do sítio. Apontamentos de Kubitschek (2000) trazem elementos importantes do período de implantação da Capital.

Numa tentativa de ordenamento, estudos e materiais envolvendo ocupação espacial no DF podem ser classificados por:

$\rightarrow$ Área de atuação - destacando-se, historiadores, arquitetos, geógrafos, geólogos e cartógrafos. 
$\rightarrow$ Tipo de produção do conhecimento - artigos, teses, dissertações e livros. Destacam-se as teses produzidas na UNB e os livros da Coleção Brasília.

$\rightarrow$ Tipos de fontes de informação - podendo ser Jornalística, por meio de periódicos como Correio Brasiliense ou, através de órgãos governamentais (SEDHAB, EMATER, CODEPLAN).

$\rightarrow$ Áreas de conhecimento envolvendo temas relacionados. Os dois principais focos para fazer a ligação com esta pesquisa são uso e ocupação do solo e questões ambientais.

Levantamento de dados sobre produção agrícola e aspectos econômicos das áreas rurais são encontrados em materiais produzidos pela EMATER, CODEPLAN e IBGE. Estudos específicos sobre as áreas rurais do DF foram realizados por Pébayle (1971), Tavares (1995) e Botelho Filho(2001). Pébayle mapeou o uso do solo nas primeiras décadas. Tavares traz informações históricas por meio de suas vivencias em órgãos governamentais. Filho aborda relações rural-urbanas sob o aspecto econômico.

Ferreira e Paviani fazem importantes análises geográficas do DF ao acompanharem seu desenvolvimento ao longo dos anos. Nos livros da coleção Brasília, junto com outros pesquisadores, Paviani organiza temas sobre o DF que envolvem planejamento e organização espacial. Sânzio (2012), enfatiza as vertentes de crescimento urbano. Gouvêa (1996) aborda a questão da Habitação de interesse Social. Guia e Cidade (2010) abordam reprodução das desigualdades sócio-espaciais. Gonzáles (2010) aborda a gestão urbanística.

Artigos, dissertações e Teses sobre Brasília, envolvendo aspectos de uso e ocupação, auxiliam no entendimento de situações existentes nas áreas rurais. COSTA (2011) estuda o processo administrativo e histórico, de criação das Regiões Administrativas do Distrito Federal e faz um apanhado da Cartografia dos planos diretores do Distrito Federal. Brito (2009) estuda o processo de ocupação por meio do sistema viário. Oliveira (2008) observa o trajeto da implementação do Planejamento Urbano no DF. Silveira (1999) aborda alterações no planejamento espacial do DF. Mancini (2008) avalia os custos da urbanização dispersa no DF. Malagutti (1996) faz um apanhado sobre o processo de criação dos Condomínios. Giuliana de Freitas (2013) estuda os condomínios irregulares e as políticas de regularização. Fortes et al (2007), 
abordam mapeamentos de imóveis da união e regularização fundiária. Silva (2011) aborda assentamentos irregulares e habitação de interesse social. Ainda, específicos de RA's, envolvendo uso e ocupação do solo, tem-se: Araújo (2009) sobre São Sebastião; Alves (2009) sobre Vicente Pires e, Tania Freitas (2013) sobre o Gama.

Envolvendo o planejamento espacial, tem-se o estudo de 2007 para o PDOT de 2009, o material elaborado pelo IPEA (2001) sobre Gestão do uso do solo e disfunções do crescimento urbano e, informações da página eletrônica da SEDHAB. Entre as informações disponibilizadas pela SEDHAB destacam-se as imagens aéreas, os materiais sobre Planos Diretores e o dossiê rural.

Nas questões ambientais destacam-se: Fonseca (2001) em estudos sobre o lago Paranoá; Clarissa de Freitas (2013) sobre relações de expansão urbana e proteção ambiental; Gonçalves (2012) sobre recursos hídricos na bacia do Pipiripau e, Sano et al (2005), sobre demanda de água para irrigação de pivôs centrais. Os estudos para elaboração do Zoneamento Ecológico Econômico (embora ainda não finalizado), são ricos em informações envolvendo uso e ocupação do solo e questões ambientais no Distrito Federal.

Entre os o materiais que abordam uso e ocupação do solo rural e questões ambientais, dois destacam-se nas análises: a pesquisa elaborada pela UNESCO, sobre uso do solo e vegetação e o estudo realizado por Tesa e Baptista (2015) estimando a tendência de supressão de vegetação para a Área Metropolitana de Brasília. Os estudos da UNESCO apresentam tendências de alterações no uso do solo ao longo dos anos, como pode ser observado nas figuras 02 e 03.

Assim como os dados da UNESCO, Tesa e Baptista (2015) realizaram estudo estimando a tendência de supressão de vegetação para a Área Metropolitana de Brasília no período de 1973 a 2013. 'Entre 1973 e 2013, cerca de 15\% da área foi desmatada, mais de $70 \%$ se manteve inalterada e menos de $13 \%$ apresentam regeneração' (TESA \& BAPTISTA, 2015, p300). O estudo verificou dois períodos distintos: pouca alteração de 1973 a 1990 e redução acentuada de 1990 a 2013. Apontou ainda cenários futuros caso a tendência de redução da vegetação permaneça, porém ressalta elementos de contenção: 
...caso a tendência verificada no período se mantenha, em 2023 haverá a total supressão de vegetação fotossinteticamente ativa na AMB. É provável que essa tendência não se confirme, pois instruções normativas de uso e ocupação, bem como ambientais; condicionantes naturais, tais como vegetação em APP e APM; além da ação do poder público, atuam como alteradores de tendências. Mas isso somente poderá ser verificado com novos dados referentes a novos anos (TESA \& BAPTISTA, 2015, p.301).

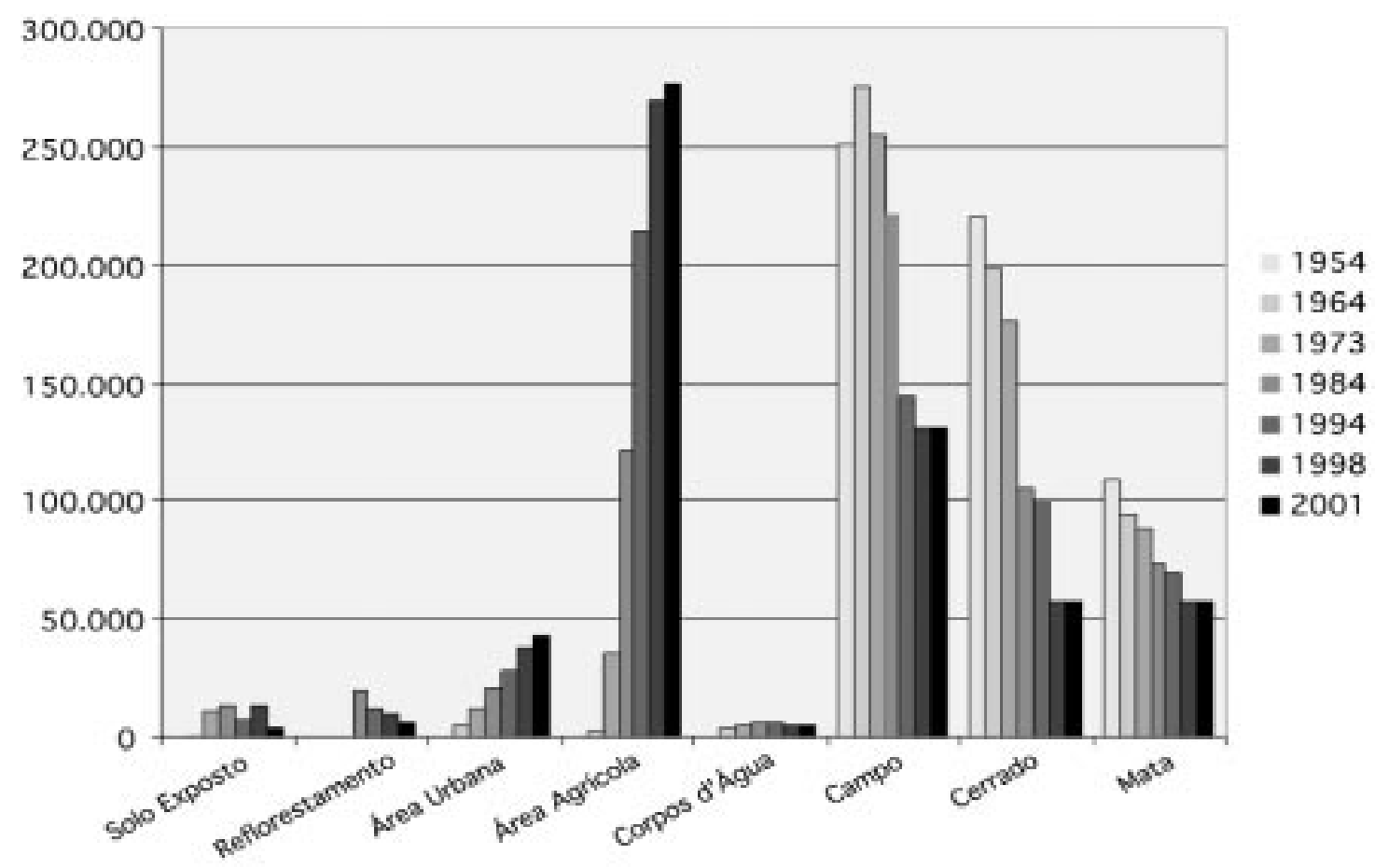

Figura 2: Quantificação multitemporal das áreas de cobertura vegetal e uso do solo (ha). Fonte: UNESCO, 2002.

Os dois estudos são importantes indicadores da tendência à supressão da vegetação natural. Os impactos do crescimento de áreas agrícolas e urbanas são observados na diminuição das paisagens naturais. 
MAPA 2 -USO DO SOLO E VEGETAÇÄO DO DF EM 2001

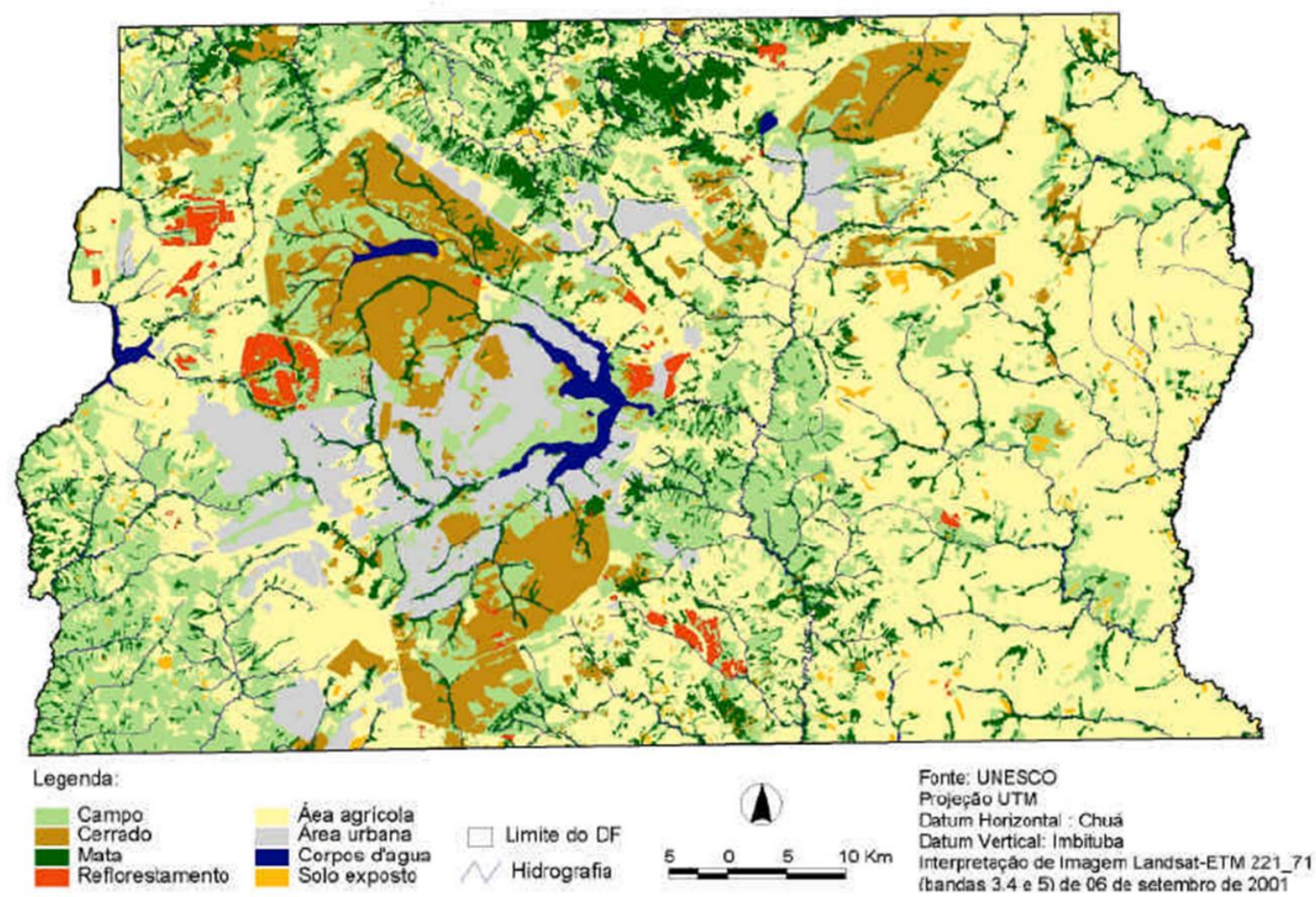

Figura 3: Uso do solo e vegetação do DF em 2001. Fonte: UNESCO, 2002. 


\section{MATERIAL E MÉTODOS}

\subsection{Material}

Foram empregadas duas principais vertentes de informação na pesquisa bibliográfica:

$\Rightarrow$ Livros e trabalhos de pesquisadores sobre o Distrito Federal e;

$\Rightarrow$ Documentos e dados produzidos por órgãos públicos.

Para a realização da pesquisa trabalhou-se com a coleta de dados secundários devido à abordagem histórica empregada.

Foram levantados trabalhos que abordam elementos de ocupação espacial no DF e trazem informações relevantes ao entendimento do processo de ocupação sócio espacial das áreas rurais. Além das Teses, Dissertações, livros e artigos, o material da pesquisa bibliográfica foi buscado basicamente nos seguintes órgãos:

$\rightarrow$ Arquivo público - mapas históricos e bibliografias;

$\rightarrow$ SEDHAB - mapas, fotografias aéreas, documentos, legislação e produções técnicas;

$\rightarrow$ Secretaria de agricultura (Agricultura Familiar e Assuntos Fundiários) documentos e legislação;

$\rightarrow$ TERRACAP (área rural) - situação fundiária de áreas rurais (mapeamento inconcluso);

$\rightarrow$ EMATER - Dados de produção agrícola;

$\rightarrow$ CODEPLAN - Publicações e dados estatísticos;

$\rightarrow$ CAESB - Dados de abastecimento nas áreas rurais;

Outras fontes de informações importantes foram:

$\rightarrow$ Artigos de jornais e periódicos (Correio Braziliense);

$\rightarrow$ Dados estatísticos (IBGE, Censo agropecuário DF, PNAD). 
As informações dos órgãos públicos foram obtidas por pesquisas in loco, publicações do órgão e materiais disponibilizados em sítios da internet. Cartogramas elaborados por órgãos públicos foram utilizados ao longo do texto para auxiliar as análises.

Ainda em relação aos órgãos públicos, a facilidade de acesso a dados atuais não é a mesma em relação a períodos passados, dificultando comparações numéricas. Muitas informações foram recolhidas devido a iniciativas de sistematização de técnicos dos órgãos (como é o caso de dados de produção agrícola elaborados por técnicos da EMATER). Observa-se uma dificuldade de planejamento para elaboração e sistematização dos dados produzidos nos órgãos.

Outras dificuldades enfrentadas são as variações de informações sobre um mesmo tema entre os diversos órgãos públicos e as diferentes abordagens. Cada órgão aborda as áreas rurais segundo suas prioridades. Por exemplo, a CAESB realiza uma setorização de áreas rurais distinta da SEDHAB e da EMATER.

Fotografias aéreas do acervo do GDF, disponibilizadas no site da SEDHAB, proporcionaram o acompanhamento das alterações ao longo dos anos. Porém devido às diferenças de escalas, ângulos de retiradas das fotos e, alterações na localização, não foi possível fazer uma sobreposição das fotos para análise comparativa. As mesmas auxiliam apenas na visualização de alterações no uso e ocupação do solo.

Algumas comparações de mapas e análise de dados não foram possíveis de serem realizados. A inviabilização envolveu questões temporais (o cadastro das áreas rurais ainda encontrava-se em elaboração pelo GDF no período da pesquisa) e técnicas (mapas inadequados para comparações temporais sobre um mesmo assunto).

Procurou-se portanto, fazer uma análise qualitativa das tendências por período analisado por meio de elementos de análise.

\subsection{Métodos}

A perspectiva de análise neste trabalho compreende o rural olhando para 0 urbano no contexto de uma metrópole como Brasília. Um olhar diferenciado dos 
diagnósticos tradicionais, como é o caso dos Planos Diretores, nos quais o foco do planejamento recai sobre as áreas urbanas, e o rural encontra-se sempre em função do crescimento urbano. Neste caso o foco são as áreas rurais que vêm paulatinamente se transformando em urbanas ou sendo caracterizadas em função destas.

Para a construção do método levantou-se a necessidade de estudar variações ao longo do tempo e empregar critérios ou categorias que pudessem ser analisadas nestes recortes temporais.

A pesquisa realiza-se, portanto, pela análise do processo histórico, desde os antecedentes ao período de implantação da nova capital até a caracterização da situação atual. Envolve a atuação do Estado e de agentes socioeconômicos. É elaborada por meio de uma periodização que compreende:

Antecedentes e a primeira década - Envolve desde os estudos em torno da definição do local até o período de implantação com a proposta de áreas agrícolas abastecendo a capital. A figura 4 ilustra a chegada dos Candangos para trabalhar na construção de Brasília. As demandas por abastecimento já eram uma realidade neste período devido ao incremento populacional.

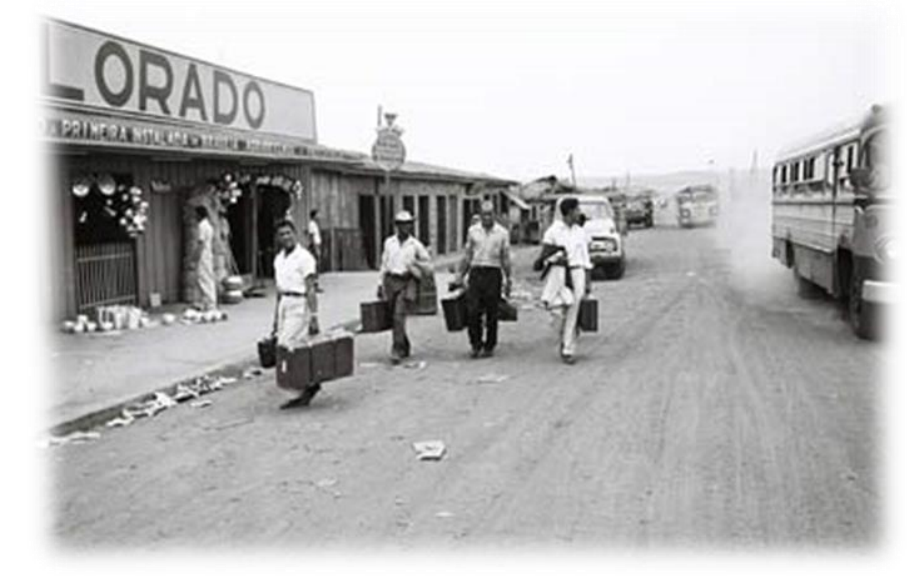

Figura 4: Chegada dos Candangos para trabalhar na construção da Capital. (Fonte: Arquivo Público do DF)

Décadas de 1970 e 1980 - Abordando processos de consolidação da Capital, onde sobressaem a agricultura mecanizada, com ênfase na grande produção e projetos habitacionais para baixa renda. A figura 5 ilustra as situações precárias iniciais das 
áreas habitacionais implementadas pelas políticas públicas do período. Visavam à remoção da população de ocupações irregulares de outras áreas urbanas, mas criavam novos nucleamentos urbanos em áreas que eram rurais.

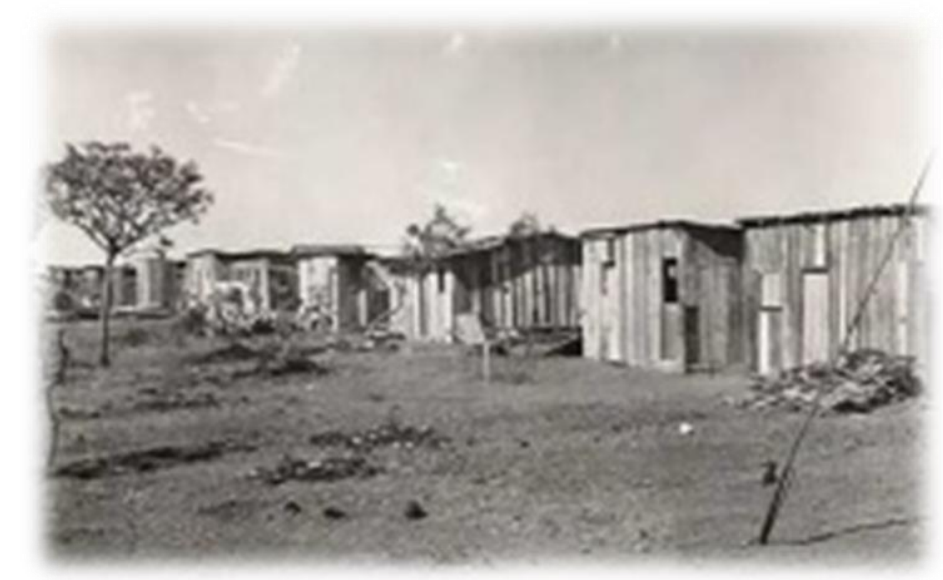

Figura 5: Ceilândia no começo, barracos recém-construídos - junho de 1971. (Fonte: http://www.vitruvius.com.br/revistas/read/minhacidade/07.074/1940 Aldo Paviani. Acesso em 02/02/2015)

Décadas de 1990 e 2000 - Expansão urbana sobre áreas rurais e tentativas de ordenamento territorial. A figura 6, de São Sebastião, representa este processo de expansão urbana em áreas rurais. A região representa uma mudança no ordenamento territorial com o aumento dos condomínios e a inviabilidade da represa.

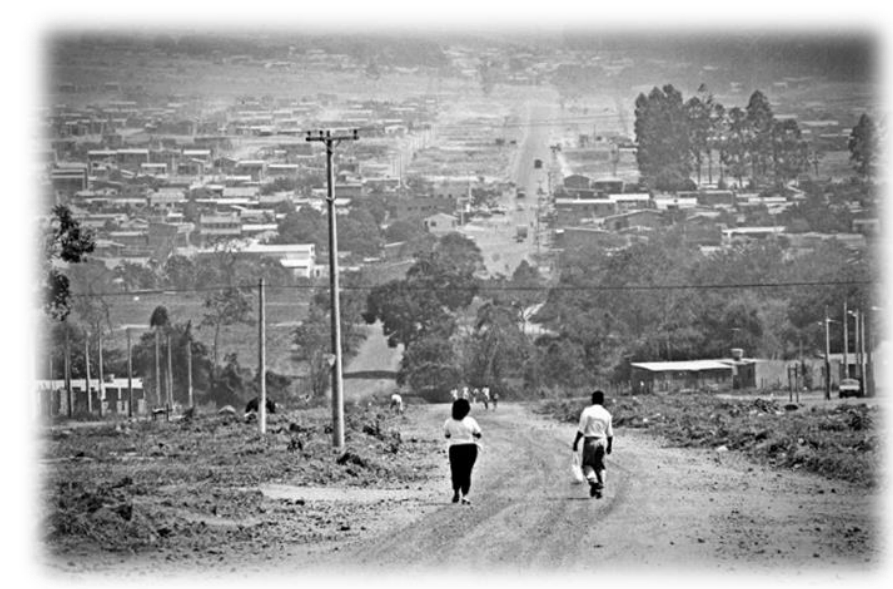

Figura 6: Agrovila São Sebastião em meados de 1992.

(Fonte: Arquivo Público do Distrito Federal)

O ordenamento em décadas, abrangendo os períodos acima, agrupados em torno de duas décadas cada, foi a forma abordada neste trabalho no intuito de facilitar a análise. Há que se considerar que existem situações de transição e fatos históricos 
ocorridos num período que se encontram melhor relacionados com o período seguinte. Conforme aponta Milton Santos:

A história é uma totalidade em movimento, um processo dinâmico cujas partes colidem continuamente para produzir cada novo momento [...] A acumulação do tempo histórico permite-nos compreender a atual organização espacial. (SANTOS, 1985. p. 72).

Considerando a perspectiva de análise apresentada acima, procurou-se aspectos que pudessem enriquecer a análise nos períodos de estudo, trazendo diferentes formas de abordagem. Os períodos são analisados com o emprego dos seguintes elementos de análise: econômico, ambiental, social e espacial.

O trabalho envolve políticas de planejamento e desenvolvimento, bem como legislações, que interferem nas áreas rurais nos períodos estudados. São abordados políticas e instrumentos que tiveram importância na conformação das áreas rurais no DF.

A análise das políticas públicas e a atuação governamental poderia representar outro aspecto de análise. Porém, uma vez que as políticas abrangem questões sociais, econômicas, ambientais e espaciais, são abordadas nos elementos de análise empregados, podendo estar presentes em mais de um deles. Embora um mesmo instrumento de política pública possa repercutir em mais de uma aspecto, sua abordagem ocorre segundo a relevância do item a ser analisado.

É preciso esclarecer também que os instrumentos abordados não correspondem à totalidade da legislação relativa às áreas rurais do Distrito Federal. Buscou-se apenas discutir instrumentos que foram decisivos no processo histórico de constituição das formas de uso e ocupação dessas áreas e relevantes para a análise.

Os elementos de análise empregados compreendem:

\section{A. Aspectos Econômicos}

Tipos de uso e ocupação da terra, trabalho e renda, aptidão agrícola das terras, infraestrutura local. Abrange aspectos de uso e ocupação (agricultura/pecuária/lazer...) com suas alterações ao longo dos períodos e a 
relação/interação com a área urbana, além de aspectos produtivos (produção, comercialização, transporte...).

Os instrumentos de planejamento caracterizados por reforçar a estruturação econômica das áreas rurais envolvem a produção agropecuária, o uso das terras rurais e o sistema viário (para facilitar o escoamento da produção) dentre outros.

\section{B. Aspectos Ambientais}

Envolve as alterações e diminuições de reservas, características do sitio físico, agravos ambientais e legislações ambientais. Admitindo-se o impacto no processo de ocupação do solo, tanto urbano quanto rural, procurou-se levantar agravos do uso agrícola, avanços da ocupação urbana sob as áreas rurais e da ocupação rural sobre áreas naturais. Procurou-se também abordar instrumentos de planejamento referentes à questão ambiental que influenciaram no processo de ocupação espacial do DF.

\section{Aspectos sociais}

Envolve questões de ocupação do território. A escolha da palavra social para esse elemento de análise está relacionada à questões demográficas e migratórias, oriundas de movimentos populacionais. Aborda as pressões do crescimento urbano sobre o espaço rural.

O incremento populacional, oriundo dos processos migratórios, pressionou a implantação, ao longo dos anos, de políticas habitacionais para atender as demandas por moradia dessa população. Os espaços rurais do DF são importantes cenários dessas políticas na implementação de novos assentamentos urbanos.

\section{Conforme aponta Carlos:}

[...] a prática sócio-espacial real (objetiva e subjetivamente), ganha sentido como produtora de lugares encerrando em sua natureza um conteúdo social dado pelas relações sociais que se realizam num espaço-tempo determinado, enquanto processo de produção, apropriação, reprodução da vida, da realidade, do espaço em seus descompassos, e, portanto, fundamentalmente, em suas contradições. (CARLOS, 2011, p. 71).

\section{Aspectos Espaciais}


Envolve questões de planejamento do território. Considerando que as questões econômicas, sociais e ambientais levantadas acima ocorrem no espaço, este não deveria ser um critério de análise. Contudo, o emprego da palavra espacial como um elemento de análise está relacionado ao seu planejamento. Busca-se aqui levantar as políticas e tentativas de planejamento e controle espacial bem como os diversos Planos de Ordenamento do território. Corresponde também às alterações espaciais das áreas rurais ao longo do tempo. Nesta categoria, ainda será abordada a situação fundiária - posse/titularidade (de quem é a terra/ o que representa).

As imagens das figuras 7 e 8 , visam referendar os elementos de análise empregados. O cultivo de milho no PADF indica áreas de produtividade agrícola relativas à aspectos 'econômicos'. O candango chegando à capital, com uma mala nas costas, ilustra a migração e o incremento populacional indicativos do aspecto 'social'. A estação ecológica de Águas Emendadas enfatiza a importância da preservação dos mananciais na região e a necessidade de um elemento de análise 'ambiental'. Por fim, a imagem da figura seguinte, do Plano de Lucio Costa para a implantação da capital, ilustra a ênfase dada ao planejamento do espaço no histórico do DF, remetendo à aspectos do planejamento 'espacial'.

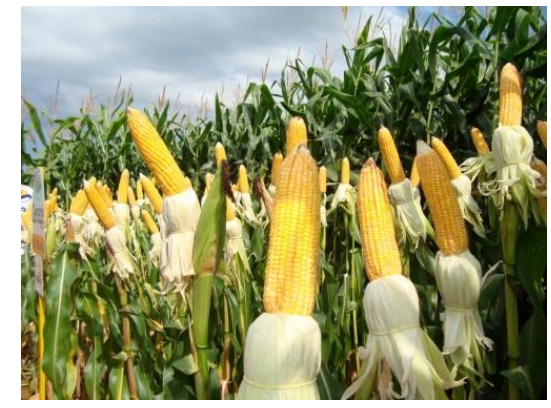

a)

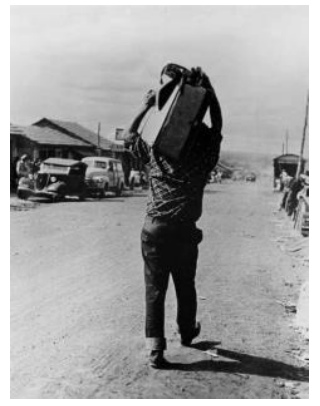

b)

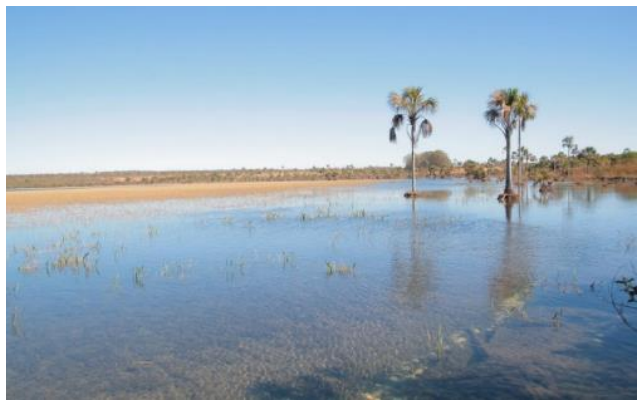

c)

Figura 7: Cultivo de milho no PADF (Fonte: http://www.coopadf.com.br/fotos/69-dia-de-campo-milho-e-soia2012); Candango chegando à capital (Fonte: Arquivo Público DF); e Estação ecológica de Águas Emendadas (fonte: http://verdecapital.org) 


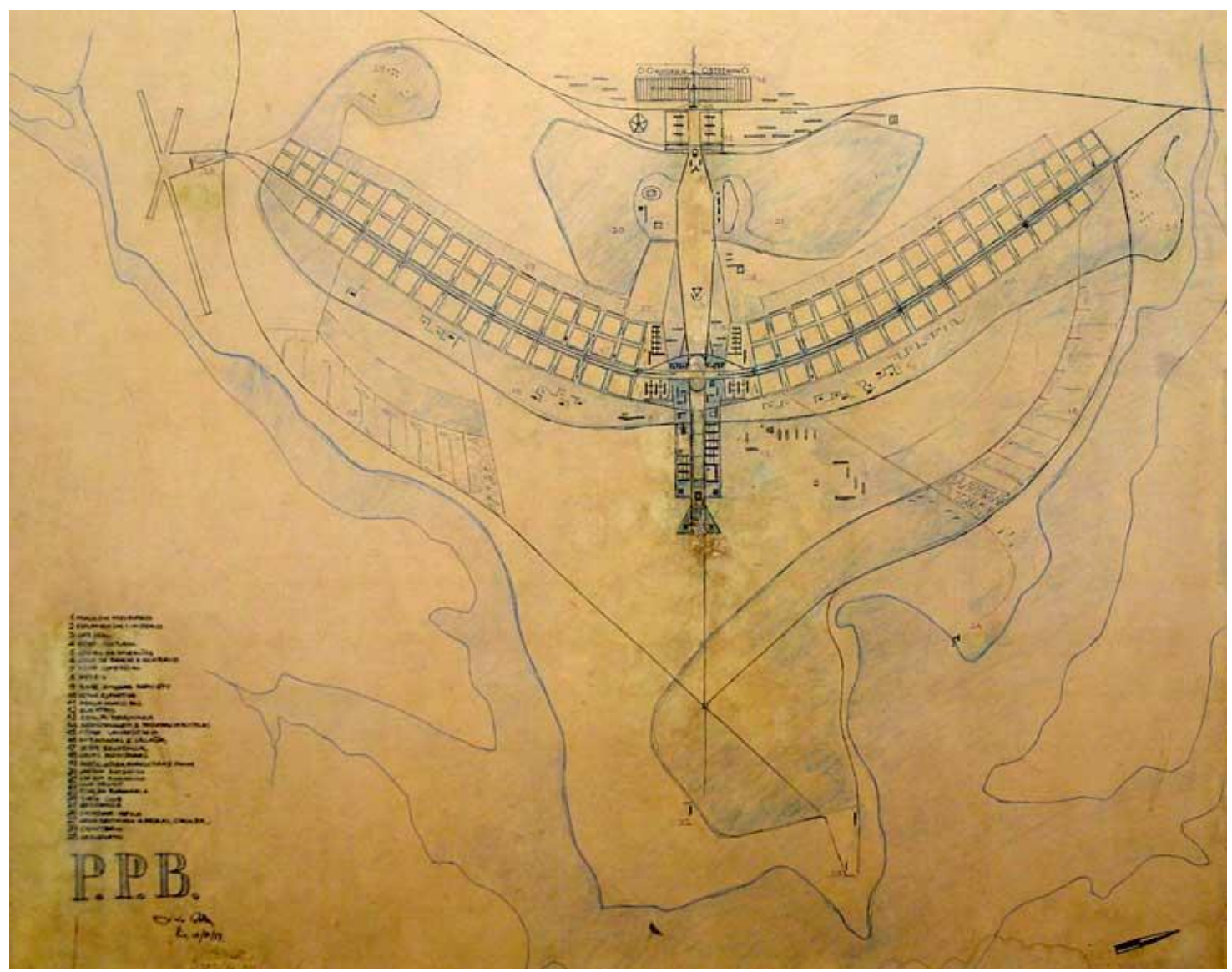

Figura 8: Plano Piloto de Brasília.

(Fonte: COSTA, Lucio. Relatório do Plano Piloto. Brasília, 1957).

Na síntese, ao final de cada período, buscou-se elaborar figuras esquemáticas ilustrativas de informações relevantes das décadas. Envolvem elementos dos critérios de análise empregados. São indicados núcleos urbanos, áreas ambientais e áreas rurais importantes no período, dentre outros. Gráficos de uso do solo, elaborados a partir de material da UNESCO, ilustram tendências nas alterações ocorridas. Além das figuras esquemáticas, ao final dos períodos há um quadro síntese dos pontos relevantes de cada aspecto.

Na discussão dos resultados, o processo histórico subsidiará a análise de transformações espaciais das áreas rurais; bem como o referencial teórico abordado no capítulo de Revisão da Literatura. Os elementos de análise, empregados nos recortes temporais, servirão de base para a elaboração de conjecturas futuras. 


\section{3. ÁREAS RURAIS DO DF AO LONGO DO TEMPO - IMPLANTAÇÃO}

A etapa denominada de implantação abrange dos primeiros indícios da mudança da capital até a década de 1960. Envolve caracterizações do sitio local até o período de implantação, com a proposta de áreas agrícolas abastecendo a capital.

\subsection{Antecedentes e período de implantação do DF}

\section{A. Aspectos economicos}

A ocupação do Centro Oeste caracterizou-se pela dispersão de sua rede urbana. Os períodos de expansão da ocupação territorial e ampliação da rede de cidades ocorreram, num primeiro momento, em função da mineração e, posteriormente, pela relação com a economia cafeeira da região sudeste.

\footnotetext{
"Iniciada a penetração do território, a mineração de ouro e pedras preciosas atraiu população de forma pontual em torno dos núcleos mineradores. A fixação se deu pelo criatório de gado extensivo nas áreas de campos naturais que se desenvolveu para abastecer as zonas mineradoras. Com o declinar da atividade mineira houve a emigração de população e a região passa a uma economia de subsistência de base agrícola descontínua" (FERREIRA, 2010, P.33).
}

Conforme aponta Ferreira, com a decadência das minas de ouro na região, as atividades produtivas estavam relacionadas ao setor primário: pecuária extensiva (empregando pastagens naturais) e lavoura de subsistência. A construção de Goiânia, pelo programa "Marcha para o oeste" impulsionou o processo de interiorização da economia brasileira, gerando um surto de desenvolvimento local e fluxo migratório de outras regiões do país.

Em relação às áreas rurais da região, a produção agrícola era pouco expressiva e de subsistência. Apresentava uma maior relevância apenas a pecuária bovina. Nas falas oficiais se preconiza a lógica de ocupação do 'espaço vazio' do planalto central, desconsiderando a conformação espacial preexistente, um espaço rural sob o qual giravam as relações sociais locais e uma economia agrícola incipiente: 
Ao contrário do que se costuma afirmar, o local em que foi implantada a cidade não era um vazio demográfico. Embora pouco habitado, tinha uma ocupação efetiva, nos moldes do Centro-Oeste brasileiro: grandes latifúndios de pecuária extensiva, lavouras de subsistência (arroz, feijão e milho), indústrias de couros, peles, alimentos, calçados e pequenos núcleos urbanos: a cidade de Planaltina e a vila de Brazlândia. (FERREIRA, 2010, p.45)

Mas foi com a transferência da capital federal - ligada ao projeto de integração Nacional do Governo de Juscelino Kubitschek - que ocorre maior impacto social e econômico na região. Brasília surge como um Pólo de desenvolvimento regional, de atração de fluxos populacionais, atuando como um 'centro de gravidade' ao redor do qual orbitam realidades tipicamente agrárias. (GUIA \& CIDADE, 2010, p.149)

Conforme apontam estudos do IPEA, a criação de Brasília fez parte da concretização de um projeto nacional de promover a interiorização do desenvolvimento econômico e a integração do território: "O Objetivo era desconcentrar o desenvolvimento em curso, fortemente concentrado na faixa litorânea e na região Sul." (IPEA, p.38) O que fica claro também nas palavras de Juscelino Kubitscheck:

O grande desafio da nossa História estava ali: seria forçar-se o deslocamento do eixo do desenvolvimento nacional. Ao invés do litoral - que já havia alcançado certo nível de progresso -, povoar-se o Planalto Central. O núcleo populacional, criado naquela longínqua região, espraiar-se-ia como uma mancha de óleo, fazendo com que todo o interior abrisse os olhos para o futuro grandioso do País. Assim, o brasileiro poderia tomar posse do seu imenso território. $\mathrm{E}$ a mudança da Capital seria o veículo. O instrumento. $\mathrm{O}$ fator que iria desencadear novo ciclo bandeirante. (KUBITSCHECK, 2000, p.21)

Por uma coincidência ao tema desta pesquisa, o primeiro ato presidencial no local, ainda antes da implantação de Brasília, foi a nomeação do ministro da Agricultura:

Em tosca mesa de madeira, colocada num galpão, assinei o primeiro ato oficial no local da futura capital: a nomeação de Mário Meneghetti para o cargo de ministro da Agricultura. (KUBITSCHECK, 2000, p.52)

Apesar da necessidade da construção física da cidade num tempo exíguo (durante o mandato presidencial de JK), desde o início houve a preocupação por garantir sua estrutura. Mesmo antes do Plano Piloto ser aprovado, diversas 
providências haviam sido tomadas. Entre elas, a criação, por meio de lei, em 19 de setembro de 1956, da Companhia Urbanizadora da Nova Capital do Brasil (NOVACAP) com a finalidade de gerenciar e coordenar a construção da nova Capital do Brasil. Como a NOVACAP ainda não dispunha de verbas, fez-se empréstimos no Banco Nacional de Desenvolvimento Econômico para a construção da usina de Cachoeira Dourada ${ }^{22}$.

Foram enviados técnicos a Goiás, com incumbência de realizar observações na área, para a elaboração imediata de uma carta geográfica do local da futura capital, com vistas à prospecção dos materiais de construção, ao reflorestamento da zona e à fixação das variações meteorológicas.

As atividades do Departamento de Terras e Agricultura tiveram como base os estudos técnicos realizados pela firma Donald Belcher Associates - empresa que elaborou o primeiro mapa de solos do DF. Em relação às características das áreas rurais na região, apontam a necessidade de correção do solo para adequação ao plantio. Os técnicos da firma Donald J. Belcher, já levantavam dificuldades para o uso agrícola no local escolhido para a nova capital do Brasil:

O potencial agrícola dessa área é repartido com os Sítios Verde e Vermelho. Os solos dessas áreas requereriam fertilização adequada e supervisão do solo, as quais não poderiam ser empreendidas nos primeiros anos de existência da cidade. Entretanto, a opinião dos técnicos agrícolas é de que, sob a orientação adequada e fertilização, culturas adaptadas podem se desenvolver nessas áreas e a produtividade de toda a área bem diversificada e aumentada. A desvantagem desse Sítio nesse ponto é que o suprimento inicial de víveres deve ser importado do sul e do oeste. Isto, porém, é contrabalançado pelo fato de que a estrada principal de Anápolis-Planaltina passa por esse Sítio e os suprimentos poderiam ser imediatamente transportados para o Sítio. (CODEPLAN,1995, p.)

A nova capital, estava localizada numa região não muito própria para a agricultura, de terra semiárida, calcária, difícil de ser cultivada. Com a melhora das rodovias, o abastecimento do comércio da Cidade Livre ocorria via Anápolis. O presidente define a organização de uma subcomissão para fixar, dentro do polígono

${ }^{22}$ A Usina Hidrelétrica de Cachoeira Dourada é uma usina hidrelétrica localizada no curso médio do Rio Paranaíba, na divisa entre os estados de Minas Gerais e Goiás. Foi construída na década de 1950, para gerar a energia necessária à construção de Brasília. 
que estava sendo desapropriado, as áreas destinadas à horticultura, à avicultura e à produção leiteira.

Uma capital moderna e revolucionária, como Brasília, não poderia ficar sujeita a tais oscilações. Seu abastecimento teria de ser racionalmente programado, de forma a evitar-se a ocorrência de desníveis no fluxo dos gêneros alimentícios. Daí minha decisão de ordenar à Novacap que solucionasse, antes da inauguração da cidade, esse importante problema. (KUBITSCHECK, 2000, p.92)

Para a instalação dos agricultores que chegavam a Brasília, em grande número, o Departamento de Terras e Agricultura (DTA), vinculado à NOVACAP, destinou, inicialmente, no programa do seu primeiro ano de trabalho, uma área de 30.000 hectares. Essa área, dividida em regiões agrícolas, foi retalhada em lotes destinados a arrendamento. A primeira região loteada foi denominada Vargem da Bênção, onde, em 1959, já se encontravam 42 granjas particulares. Coube, ainda, ao DTA administrar quatro grandes fazendas, designadas Granjas Modelo: Tamanduá, Ipê, Torto e Riacho Fundo e que, durante a fase inicial de vida da capital, deveriam ter participação ativa no abastecimento alimentar da população.

Criada a pedido do presidente Juscelino Kubitschek, antes da inauguração de Brasília, a Vargem Bonita recebeu imigrantes japoneses com incentivos do governo para abastecer a cidade que viria a nascer.

O ano de 1957 foi de intensa atividade no Planalto... Em agosto, instalava-se nos arredores da capital o primeiro núcleo de japoneses, dando-se início assim à formação do cinturão verde - zona agrícola destinada a abastecer a população pioneira. (KUBITSCHECK, 2000, p. 92)

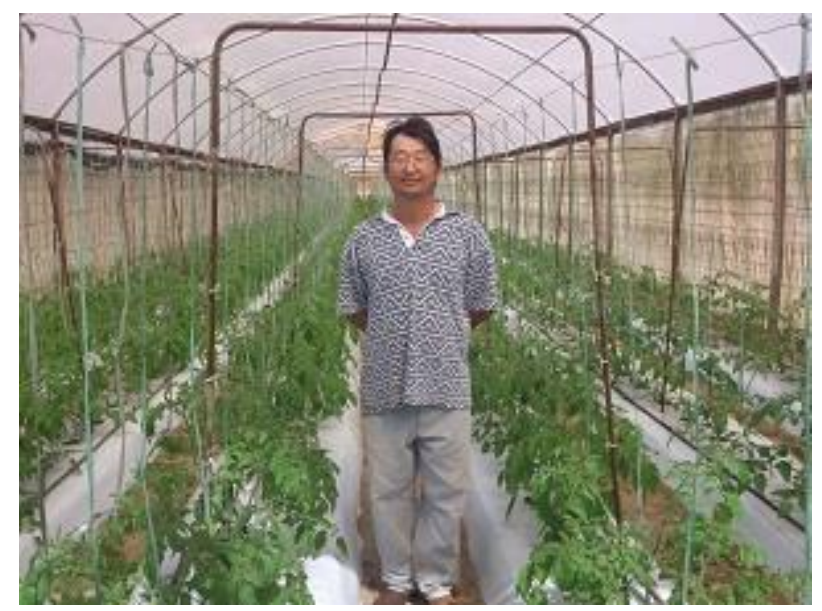

Figura 9: Agricultor descendente de japonês, da colônia agrícola Vargem Bonita planta hortaliças em chácara com a idade de Brasilia (fonte:http://esportes.estadao.com.br/blogs/selecao-universitaria/ pedaco-rural-do-df-mistura-culturas-de-brasil-e-japao/) Reportagem de 15 Junho 2013 
A assistência aos agricultores era promovida pela Divisão de Crédito, Assistência Rural e Abastecimento do DTA, por meio dos convênios denominados ETA34, ETA-44, Florestal, firmados com o Escritório Técnico da Agricultura (brasileironorte-americano) e o Ministério da Agricultura, incumbidos de fomentar, respectivamente, a produção animal e florestamento e reflorestamento do novo Distrito Federal.

Cada região agrícola disporia de um mercado, denominado Mercado do Produtor. A localização desses mercados decorreu de um estudo detalhado de cada região, para situá-los em ótimas condições de acesso aos produtores que deles se serviriam.

\section{B. Aspectos ambientais}

Para atender a constituição de 1891 na escolha do local, a Missão Cruls realizou importantes estudos da região. Resumindo suas observações, Luís Cruls apresentou dois relatórios ao governo, em 1893 e 1894. Abordava informações pouco conhecidas do Planalto Central: topografia, geologia, fauna e flora, fontes de energia, fertilidade do solo, a abundância de suas águas, a salubridade da região, o clima, e beleza panorâmica. Este estudo pode ser comparado ao que seria hoje um EIA/RIMA de grande empreendimento de impacto local.

Em 1955, ainda no intuito de definir prováveis sítios para a implantação do DF, o relatório Belcher apresentava estudos de topografia, solo, disponibilidade hídrica e drenagem.

Os Relatórios Cruls e Belcher apresentaram importantes estudos de dados físicos sobre o território do Distrito Federal. Destaca-se a questão da pouca umidade, a suscetibilidade do solo a processos erosivos e o cuidado com os recursos hídricos. 


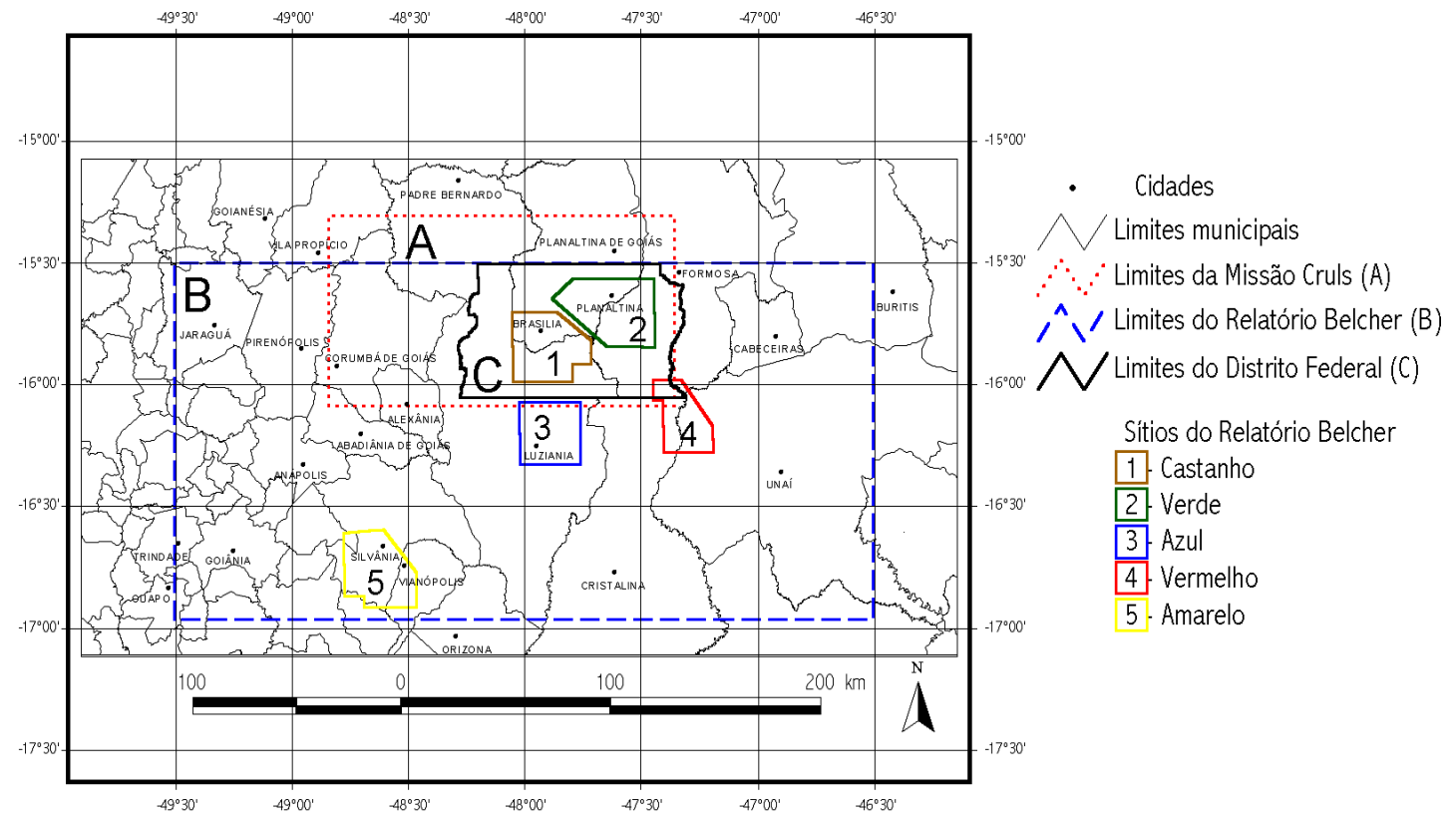

Figura 10: Localização dos limites das áreas indicadas pela Missão Cruls e pelo Relatório Belcher, inclusive dos sítios recomendados, e da área atual do Distrito Federal. (FORTES et.al.2007, adaptado de SEMARH, 2001)

\section{Aspectos Sociais}

As terras do Distrito Federal foram habitadas por índios ceramistas, agricultores e caçadores. Pertenciam a tribo dos Tapuias, conhecida por Jê: Quirixá, Cinta-Larga, Tocantinitins, Arraés, Guayazes ou Goyá, Xavante e Pedra Branca. Sua presença na região está registrada em livros, na denominação de locais, no nome de frutos, animais e plantas.

De 1960 a 1970, inverteu-se a relação entre população rural e urbana no país, o que se acentuou nas décadas seguintes, inclusive com o esvaziamento do campo. Nos anos 1960, eram os sem-terra do campo que vinham em busca do canteiro de obras de Brasília. (IPEA, 2000, p. 44)

Antes da implantação da capital, a região era pouco habitada. Dados do censo de 1960 indicavam pouco mais de três milhões de habitantes na região do Planalto Central. Ferreira levanta dados do IBGE de 1963 onde:

A cidade de Formosa, sede do município, tinha 3.631 habitantes; a população do município de Luziânia era de 19.657 habitantes, sendo 1.811 na sede; o povoado de Brazlândia tinha 113 habitantes; Planaltina contava 
com 7.335 no município e 1.385 na cidade (FERREIRA, 2010, apud IBGE,1963)

Com a implantação da Capital vieram levas de migrantes para a construção, principalmente do nordeste:

Desde 1957, o imenso canteiro de obras que representa a construção desta cidade necessita de uma abundante mão de obra. É do nordeste, dos estados da Paraíba e de Pernambuco, que chega grande parte dos operários. Em sua maioria, trabalhadores rurais fugidos da miséria e atraídos pelas promessas e que, com um entusiasmo incrível, se improvisam de pedreiros ou carpinteiros. Brasília se torna a terra prometida. A construção de uma cidade, em que são os pioneiros, Ihes dá esperança e confiança. "Em nome de Brasília" eles suportam tudo. (ROIG IN CARVALHO, 1997, p.127)

Em Conterrâneos Velhos de Guerra, Vladmir Carvalho levanta bem esta realidade nas falas dos candangos:

Eu vim da Paraíba porque lá não dava mais pra mim vier porque trabalhava na roça como agricultor e os fazendeiros não deixava nós trabalhar. Então tavam tirando os moradores pra criar gado. O motivo de eu sair pra recorrer às cidades foi esse. Não tinha mais terra pra trabalhar e saímos de lá pra fazer... caçar uma melhora pra nossa vida. (Carvalho, 1997, p.230). [...] Não, eu não vou morrer de fome lá. Porque no Ceará o pessoal tá morrendo de fome. No Ceará, o pessoal que tão lá, se almoça não janta, se janta não almoça. Que é que adianta?! Eu vou leva meus filho pra morre de fome lá? Não vou. (CARVALHO, 1997, p.344).

Com a migração acelerada para a construção da cidade diversos acampamentos, loteamentos provisórios e clandestinos foram surgindo. A criação de cidades 'satélites' antes mesmo da implantação da Capital foi uma estratégia de 'preservar Brasília', segregando espacial e socialmente a população de menor renda. (GOUVÊA in PAVIANI, 1991, p.95). Taguatinga foi criada em 1958, era ponto de parada da população que vinha para as obras da capital. Sobradinho em 1960 para acolher população transferida dos acampamentos Bananal e Vila Amauri. A Cidade Livre, hoje Núcleo Bandeirante também surgiu nesta época como núcleo comercial e a Candangolândia era um acampamento em torno dos escritórios da NOVACAP.

Paviani destaca ainda que: "Fato notável é que a atração de importantes correntes migratórias, com a construção do Plano Piloto de Brasília, criou condições para a formação de um conjunto urbano no Centro-Oeste". (PAVIANI, 2010, p. 87) 


\section{Aspectos Espaciais}

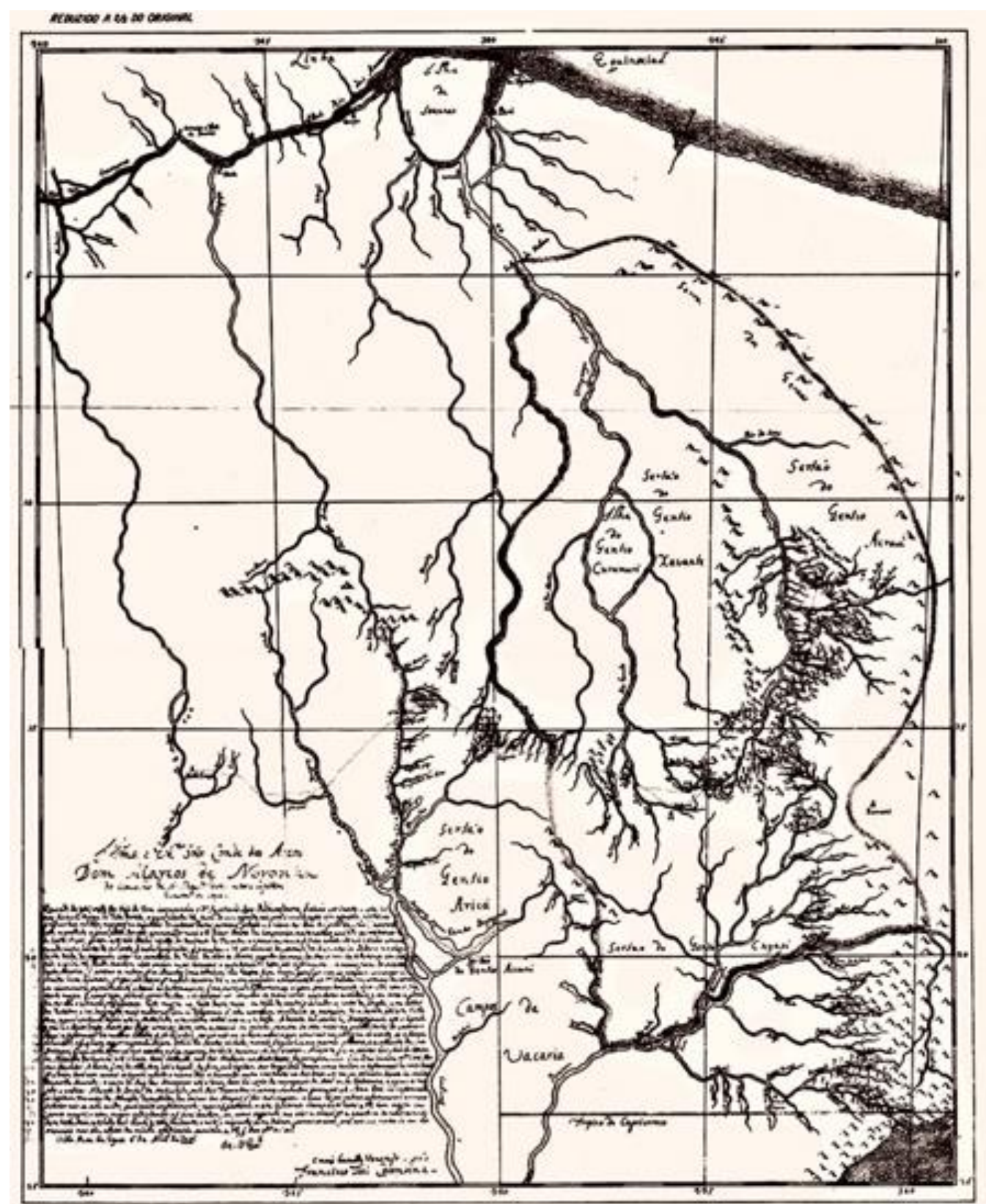

Figura 11: Carta geográfica 1891 de Goiás elaborada por Francesco Tosi Colombina (http://www.brasil.gov.br/assuntos/geral/2010/04/carta-geografica/03 mapa-

FrancescoTosiColombina.jpg/view)

A intenção de transferir a capital para o interior teve suas primeiras manifestações ainda no período colonial. Na época (1751) fora elaborada uma carta geográfica de Goiás realçando o valor estratégico do Planalto Central. 
A Constituição de 1891 estabelece em seu artigo 3: "Fica pertencente à União, no Planalto Central da República, uma zona de 14.400 km, que será oportunamente demarcada para nela estabelecer-se a futura Capital Federal”. As Constituições de 1934 e 1946 reforçam a transferência da capital para o planalto central.

A missão Cruls (1894), os Relatórios Polli Coelho (1948) e Belcher (1955) trazem importantes estudos sobre o planalto central para a escolha da melhor área. Porém Ferreira ressalva que o mito do sítio ótimo esconde a luta dos lugares por sediar a capital, camufla interesses locais com argumentos técnicos, quando a instalação da nova capital já se tornara um empreendimento proveitoso. (FERREIRA, 2010, p.37).

As terras que passaram a formar o Distrito Federal pertenciam aos municípios goianos de Formosa, Luziânia e Planaltina. Da área original do município de Planaltina, uma parte foi incorporada ao Distrito Federal, inclusive ao Plano Piloto.

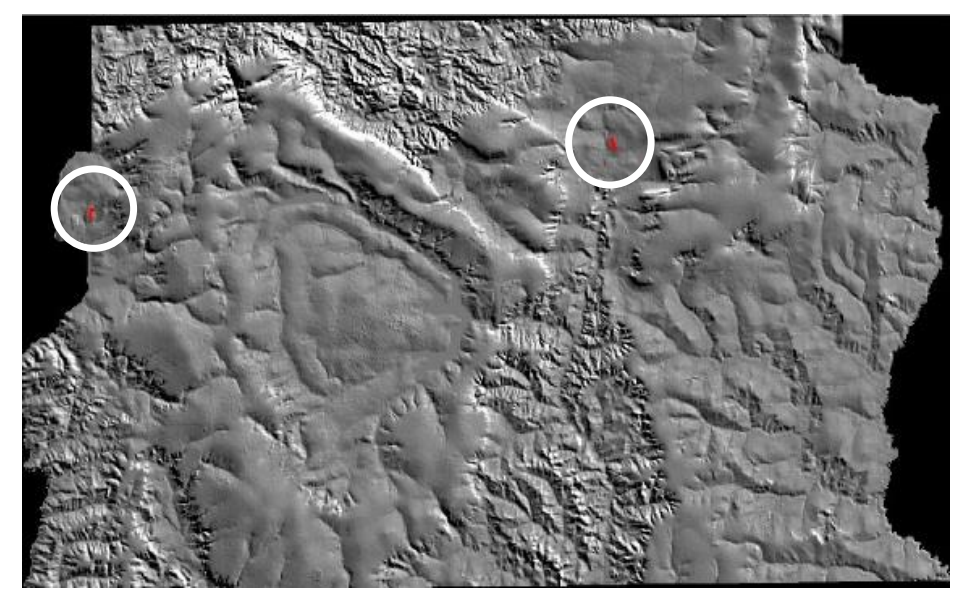

Figura 12: Indicação da ocupação urbana em 1953 sendo Brazlândia à esquerda e Planaltina à direita. Observa-se que eram pequenos nucleamentos urbanos. (Fonte: SEDUH)

Definido o local da futura capital (1955), foi solicitado ao então Presidente, Café Filho, declarar de utilidade pública, para fins de desapropriação, toda a área escolhida. Buscava-se evitar desenfreada exploração imobiliária em face da implantação da capital.

Com a negativa federal, o governo de Goiás, um dos principais interessados, se antecipa e inicia as desapropriações participando ativamente da transferência da sede do Governo para o Planalto Central. Em maio de 1955, por decreto, suspende toda e 
qualquer alienação de terras devolutas e outras de domínio estadual compreendidas na área do Distrito Federal e de suas adjacências. Em outubro de 1955, nomeia uma Comissão de Cooperação para a Mudança da Capital Federal. Esta Comissão foi a responsável pelas primeiras desapropriações feitas no território do Novo Distrito Federal criado, realizando um levantamento das propriedades existentes e de seus respectivos donos, cuidando das negociações necessárias.

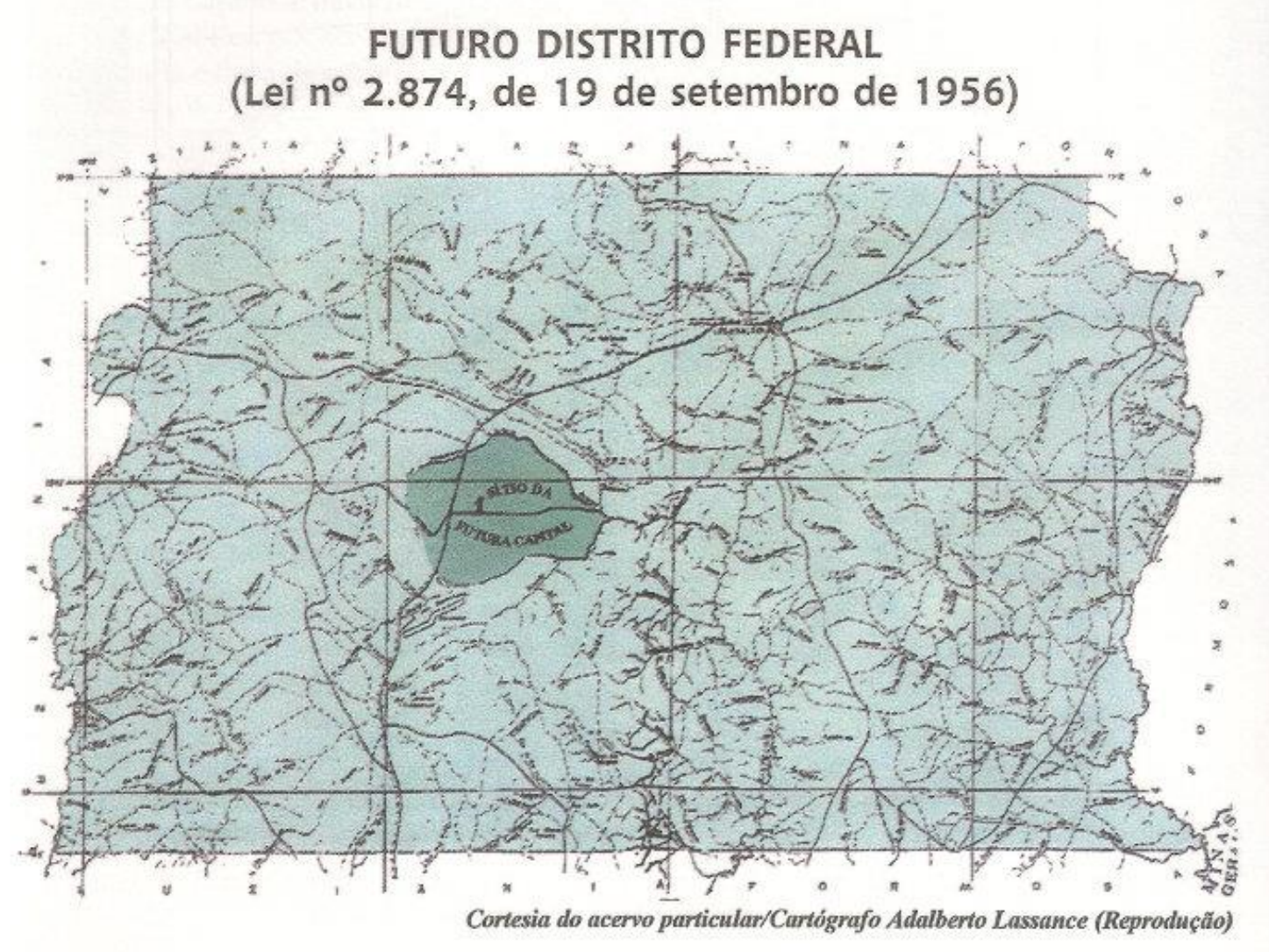

Figura 13: Fazenda desapropriada onde hoje se localiza o Plano Piloto (fonte: Correio Brasiliense)

Em novembro de 1955 foi sancionado o Orçamento da República para o ano de 1956, sendo consignada a verba de Cr\$120.000.000,00 (Cento e vinte milhões de cruzeiros) destinada à desapropriação de toda a área do Distrito Federal.

Em 30 de dezembro de 1955 a Comissão de Cooperação realiza amigavelmente a primeira desapropriação (figura 13), considerada a mais importante, onde hoje está Brasília $^{23}$. A grande área desapropriada, adquirida de Jorge Peles se denominava

${ }^{23}$ Conforme matéria de 11/12/2012, do jornal Correio Brasiliense, o sogro do ex governador Joaquim Roriz e o sócio, venderam para o estado de Goiás uma parte significativa da Fazenda Bananal: "Só que eles nunca passaram para seus nomes as terras que compraram do fazendeiro Hélio Rodrigues Queiroz, 
Fazenda Bananal e custou ao Governo da União, 800 cruzeiros cada alqueire. Os quase 4 mil alqueires ${ }^{24}$ adquiridos compreendiam a área entre os rios Bananal e Torto, onde iriam ser edificados os principais prédios da futura Capital.

Em 1956, a lei 2.874 (de 19/09/56) estabelece o Monopólio Estatal da terra, ou seja, a lei proíbe a alienação das terras a particulares. Mas, apesar da intenção de desapropriar todas as terras, atualmente a área desapropriada corresponde a 51\% do total.

Conforme reportagem do Correio Brasiliense (2012), eram 108 propriedades rurais pertencentes a 154 fazendeiros. Na hora da compra da terra, a Comissão de Desapropriação não teve condições (devido ao tempo recorde estipulado por JK) de localizar todos os que tinham direito de propriedade. Entre as dificuldades das desapropriações estão:

$\checkmark$ Documentos precários: termos genéricos sem informações precisas, apenas com nomes, sem endereços ou números de identificação, com erros grosseiros de grafia.

$\checkmark$ As inscrições das propriedades também eram imprecisas, com coordenadas marcadas a partir da casa de vizinhos, de cupinzeiros, nascentes de córregos, morros, solos acidentados, referências que se perdiam com o tempo.

$\checkmark$ A existência de 3.829 alqueires geométricos de terras devolutas, áreas em que os donos não foram localizados.

$\checkmark$ As terras no meio do Planalto Central valiam pouco na época, muitos não registravam seus bens em cartórios.

$\checkmark$ Havia contratos de gaveta e os espólios eram divididos entre famílias numerosas, com muitos herdeiros.

que nos documentos aparece como o verdadeiro proprietário. Essa cultura persiste ainda hoje, quando alguns negociantes como Peles e o sócio dele não registram a titularidade no cartório de imóveis e, com isso, deixam de pagar o imposto de transferência. A compra das terras por parte de Peles, uma gleba de 4,3 mil alqueires geométricos, ocorreu em 16 de abril de 1955, oito meses antes da desapropriação, em 30 de dezembro do mesmo ano. Esse foi o primeiro movimento de valorização de terras até então esquecidas no interior do país, mas que hoje se comparam ao valor do metro quadrado das mais badaladas cidades do mundo... Assinaram a documentação onde consta que receberam CR\$ 3.870.000,00 (cerca de R\$600 mil). O valor corresponde a três vezes o que Peles e o sócio pagaram pelas terras. O primeiro grande negócio imobiliário na capital."

${ }^{24}$ Valor aproximado devido às divergências entre informações sobre os valores dos alqueires e do valor pago. 
$\checkmark$ As desapropriações ocorreram e muitas transações não foram averbadas nos cartórios de origem. A duplicidade de informações foi o gancho para a atuação de muitos grileiros.

$\checkmark$ A valorização das terras atraiu criminosos, que se aproveitaram das brechas para falsificar documentos de propriedade, inventar herdeiros e deslocar títulos de propriedade.

Feito à mão (figura 14), em setembro de 1958, pelo engenheiro Joffre Mozart Parada, o mapa usado pela Comissão de Desapropriação, detalha as fazendas de Goiás que originaram o DF:

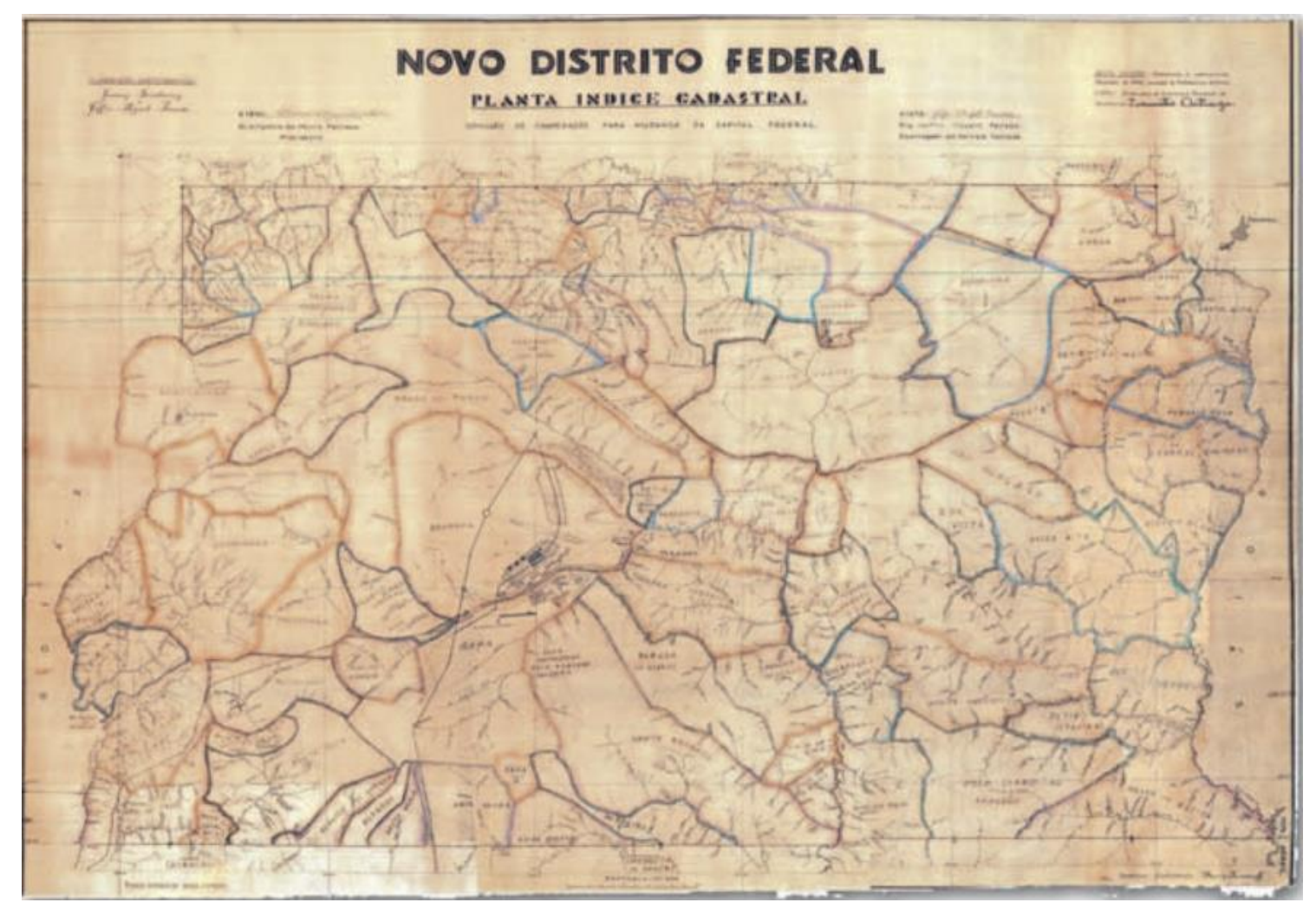

Figura 14 Delimitação das fazendas à época da implantação (Correio Brasiliense)

JK, numa jogada política envolve a oposição no processo e consegue amplos poderes para implantação da nova capital. A companhia urbanizadora seria administrada e fiscalizada por um Conselho Administrativo, um Conselho Diretor e um Conselho Fiscal, integrados, respectivamente, por 6, 4 e 3 membros. Um terço dos membros de cada um desses órgãos seria escolhido de uma lista tríplice de nomes indicados pelo maior partido da Oposição: “A Lei $n^{\circ}$ 2.874, que autorizara a 
transferência da capital, dava-me liberdade para agir como entendesse" (JK, 2000, p.49)

Em 1957, por meio de concurso nacional, o Plano Piloto de Lucio Costa define o projeto urbanístico da capital tendo como requisitos: sede administrativa do país e pólo de desenvolvimento regional.

O ano de 1958 marca o período da implementação física do Distrito Federal, quando se inicia efetivamente o processo de transformação territorial desta área nuclear do Bioma do Cerrado. Podemos caracterizar como o momento do Canteiro de Obras. (SANZIO, 2012, p10)

Quanto à comercialização de terras nas áreas adjacentes ao quadrilátero do DF, a ocorrência data de "antes mesmo de 1960", sendo que "Glebas rurais dos municípios de Luziânia e Formosa foram parceladas e vendidas como se localizadas no Distrito Federal". (FERREIRA, 2010, p. 34).

\subsection{Década de 1960}

\section{A. Aspectos Econômicos}

Após a inauguração de Brasília, em 1960, iniciou-se um rápido processo de ocupação do Território baseado na expansão da fronteira agrícola e impulsionado pela abertura de rodovias, ligando Brasília a outras regiões do país. (IPEA, 2001, p.38)

O Sistema Rodoviário do Distrito Federal, interligado ao plano rodoviário nacional, visava promover a integração, circulação e aproveitamento de riquezas. No âmbito local pretendia assegurar o crescimento do DF e promover a fixação do homem no campo. Foi definido e alterado ao longo dos decretos: 09 de 09/06/60, 2.297 de 24/03/64, 2.073 de 4/09/74, 6.632 de 3/03/82. Estruturou o território do DF orientando sua ocupação e reforçou a faixa sanitária da Bacia do Paranoá.

Com a implantação do Distrito Federal buscava-se garantir uma agricultura capaz de suprir o mercado consumidor da capital. A grande inovação seria através da alteração do sistema de posse das propriedades rurais e a organização de instituições capazes de desenvolver o setor agropecuário da região. Além do projeto urbano houve 
também um planejamento para as áreas rurais dentro do quadrilátero do Distrito Federal, alterando as antigas formas de uso e ocupação do solo. Buscava-se garantir o abastecimento da capital e, ao mesmo tempo, um cinturão verde de proteção do Plano Piloto. Predominavam concepções socializantes do uso do solo com parte das terras rurais desapropriadas e arrendadas. As demais áreas ficariam sujeitas à possibilidade de desapropriação.

Na distribuição das áreas desapropriadas, os lotes próximos ao Plano Piloto (4 ha cada) seriam para a produção de hortaliças; na área intermédia (lotes de 20 a 50 ha), para produção de alimentos e; nas áreas mais afastadas (lotes de 50 a 120 ha), para agricultura e pecuária. As primeiras diretrizes foram estabelecidas pelo Decreto 163/62 que dividiu o território em área metropolitana (compreendida pela área da Bacia do Paranoá circunscrita pela Estrada Parque Contorno - EPCT), áreas urbanas das cidades satélites e a área rural abrangendo o restante.

Conforme aponta estudo de Pébayle (1971), foram previstos vários núcleos compostos de lotes de superfícies variáveis e especializados em produções definidas. Os núcleos rurais foram previstos exclusivamente para os vales amplos. A administração quis utilizar as terras que mais se prestavam ao aproveitamento, ainda que não fossem as mais férteis. Excetuando-se as parcelas do núcleo hortícola de Vargem Bonita, que são inteiramente constituídas dos solos negros, a maioria dos lotes tinham de ser localizados de modo perpendicular ao leito dos rios.

Quatorze núcleos rurais, foram criados nos vales dos afluentes dos rios Descoberto, São Bartolomeu e Preto. As colônias agrícolas possuíam escolas e postos agronômicos. Entretanto, sua implantação enfrentou sérias dificuldades na desapropriação.

Por outro lado, numerosas instalações ilícitas vieram complicar a distribuição dos títulos oficiais de concessão. A rede de estradas asfaltadas e o grande interesse pelas terras próximas de Brasília e das cidades satélites acrescentaram novos elementos de diferenciação entre os vários núcleos.

Pébayle identifica quatro grandes grupos de núcleos rurais: 
- Núcleos rurais dos roceiros - núcleos rurais de Taquara e Ponte Alta. Agrupavam 21,6\% dos lotes do Distrito Federal; ocupados de modo ilegal, antes mesmo de terem sido criados oficialmente.

- Núcleos rurais de agricultores e de criadores de gado - Os núcleos rurais de Pipiripau, Tabatinga, Estanislau-Rajadinha e Rio Preto agrupavam 45,38\% dos lotes oficiais do Distrito Federal. Somente 7,83\% dos lotes possuíam um rebanho de mais de cinco bovinos, o essencial das atividades agrícolas concentra-se no fundo dos vales.

- Horticultores de vargem bonita e Taguatinga - agricultores de origem nacional e japonesa em Vargem Bonita e Taguatinga.

- Núcleos rurais dos "citadinos-chacareiros" - Em Taguatinga eram chácaras de fim de semana. Sobradinho I e II - Doutores granjeiros - advogados, médicos, homens políticos, altos funcionários com áreas produtivas.

Outras variações encontradas pelo pesquisador na área rural do DF:

- Mutações das fazendas tradicionais de criação de gado - a NOVACAP concedeu, aos 103 antigos proprietários, a oportunidade de continuar suas atividades com condições jurídicas definidas e técnicas novas.

- Os pequenos invasores rurais - haviam diversos tipos de pequenos invasores rurais: operários lavradores e verdadeiros agricultores. Os pequenos invasores hortelãos do Vicente Pires eram um grupo expressivo destes.

A figura 15, do material elaborado por Pébayle exemplifica os principais núcleos rurais e a ocupação agrícola da época. 


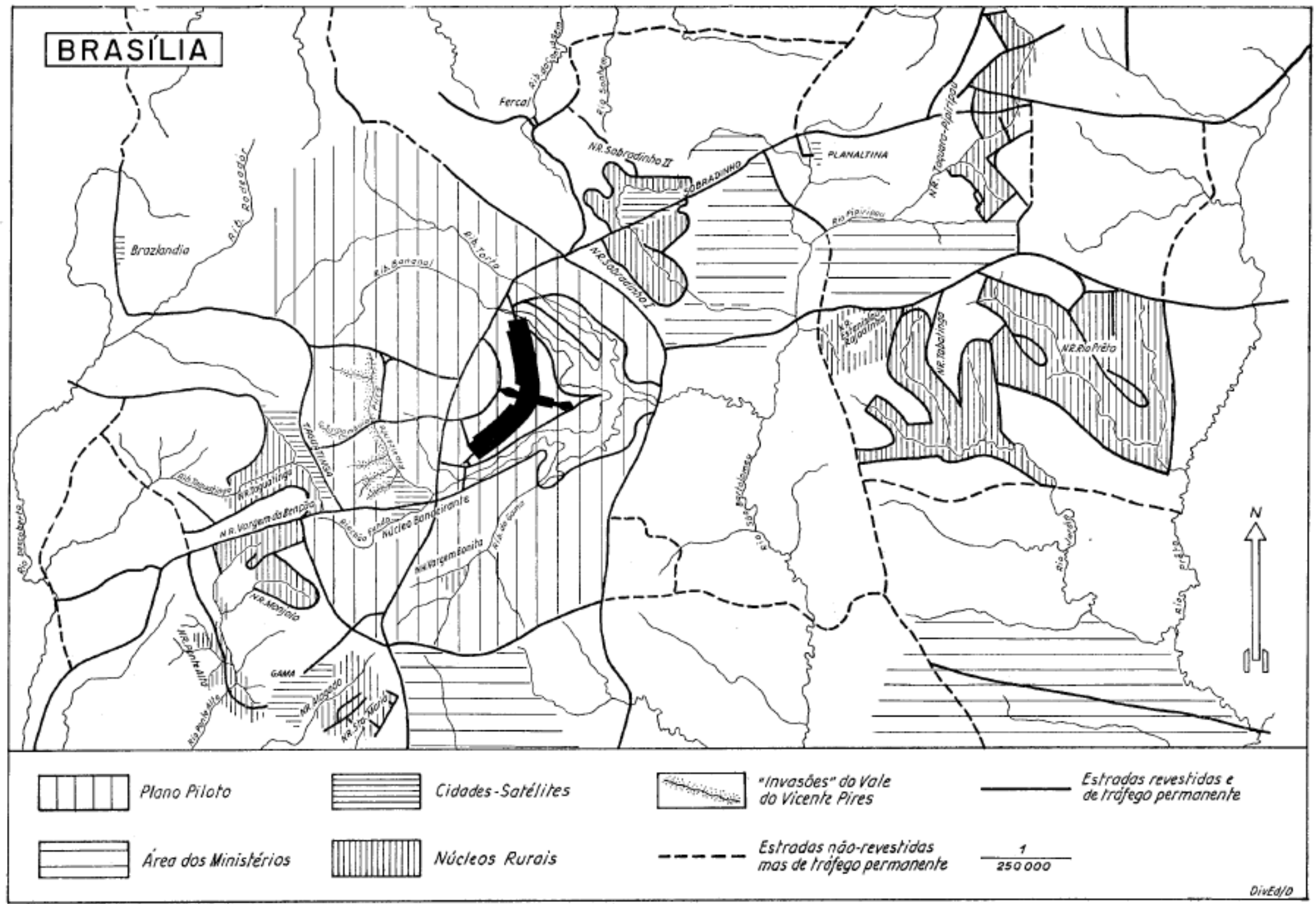

Figura 15: Ilustração elaborada por Pébayle com a configuração das áreas rurais do período. (Revista IBGE, 1971) 
As imagens da figura 16, são fotografias aéreas de 1964 e 1965 de algumas áreas rurais e locais de referência. Ilustram a situação agrícola no período.

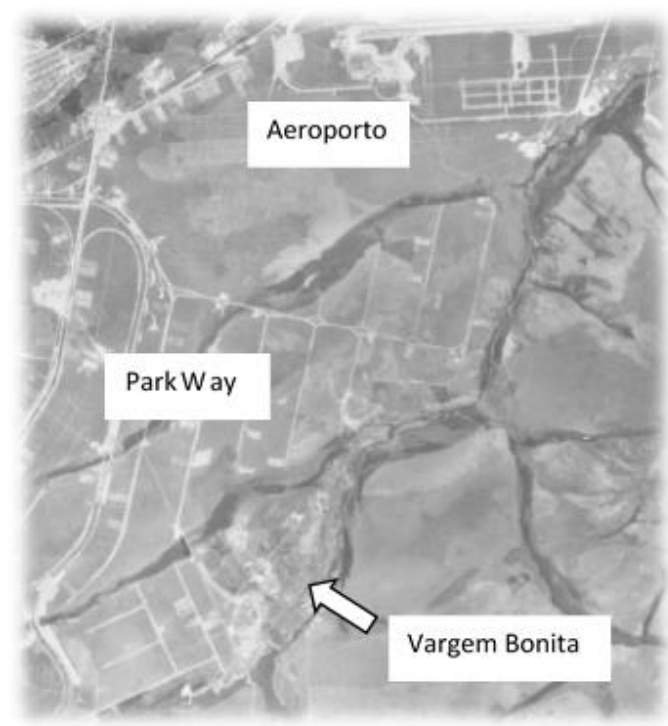

a)

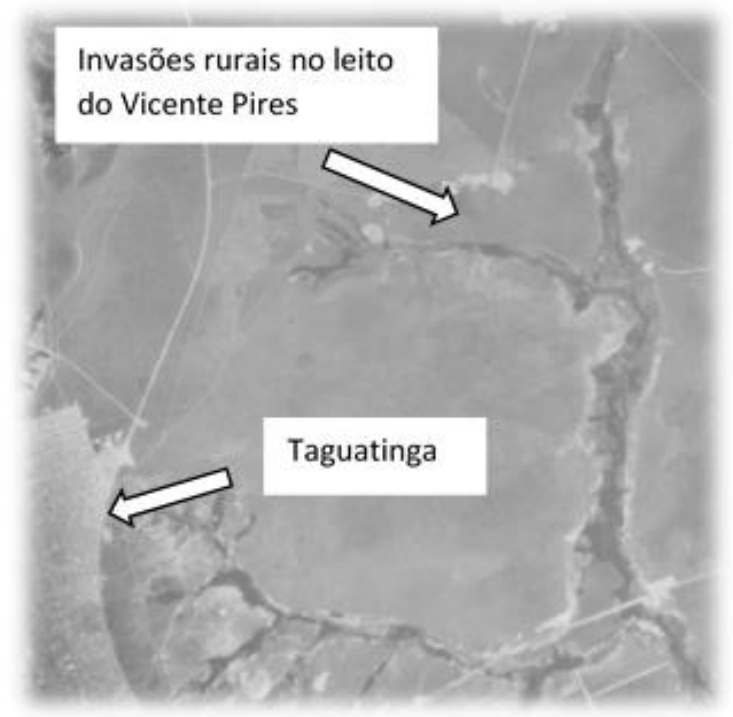

b)

Figura 16: a) Vargem Bonita b) Taguatinga. Fonte: http://www.sedhab.df.gov.br/preservacao-e-planejamento-urbano/gestao-da-informacaourbanas/mapas.html

A figura 16a (1965) mostra o núcleo rural Vargem Bonita, já com os traçados das vias do Park Way e do Aeroporto. A figura 114b apresenta Taguatinga e as invasões de posseiros ao longo do leito do córrego Vicente Pires.

A figura 17 (1965) mostra a implantação do núcleo urbano de Sobradinho, já com as áreas rurais (I e II) ao redor apresentando produção agrícola. Eram as áreas dos 'doutores granjeiros' ou 'citadinos chacareiros' denominadas por Pébayle. 


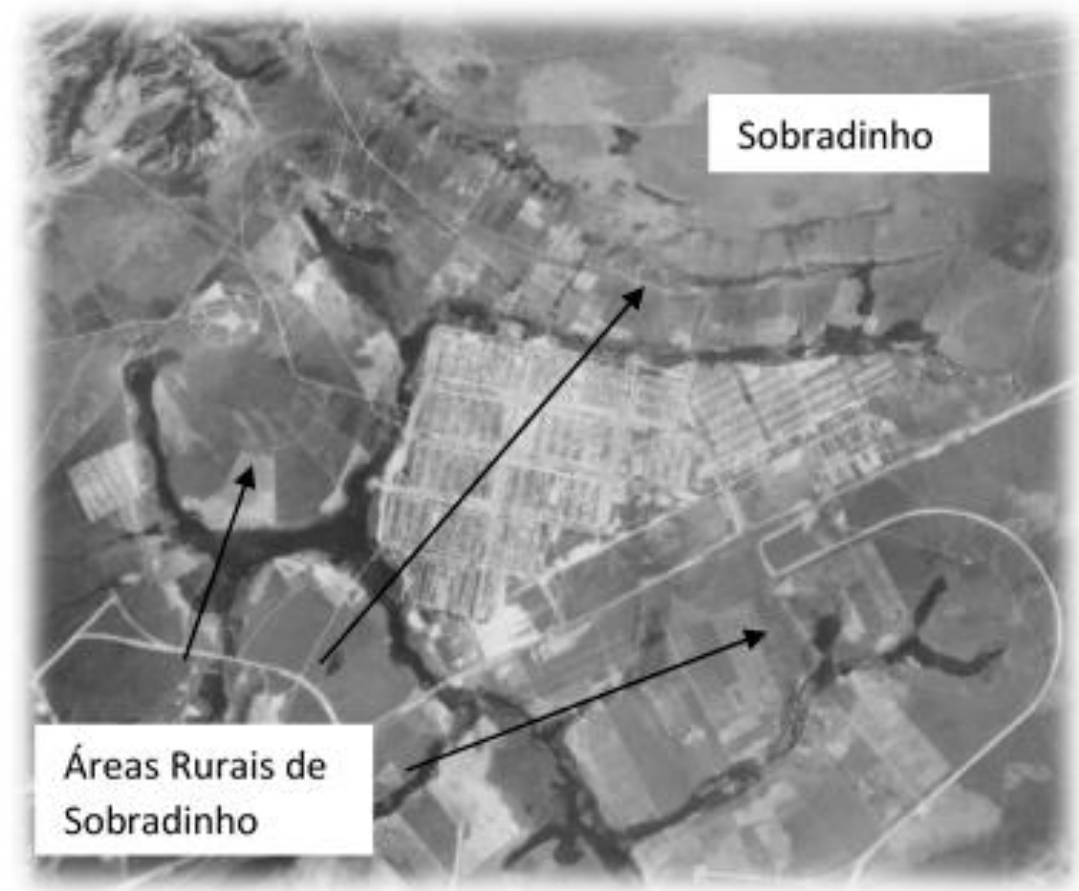

Figura 17: Sobradinho e áreas rurais.

Fonte: http://www.sedhab.df.gov.br/preservacao-e-planejamento-urbano/gestao-da-informacaourbanas/mapas.html

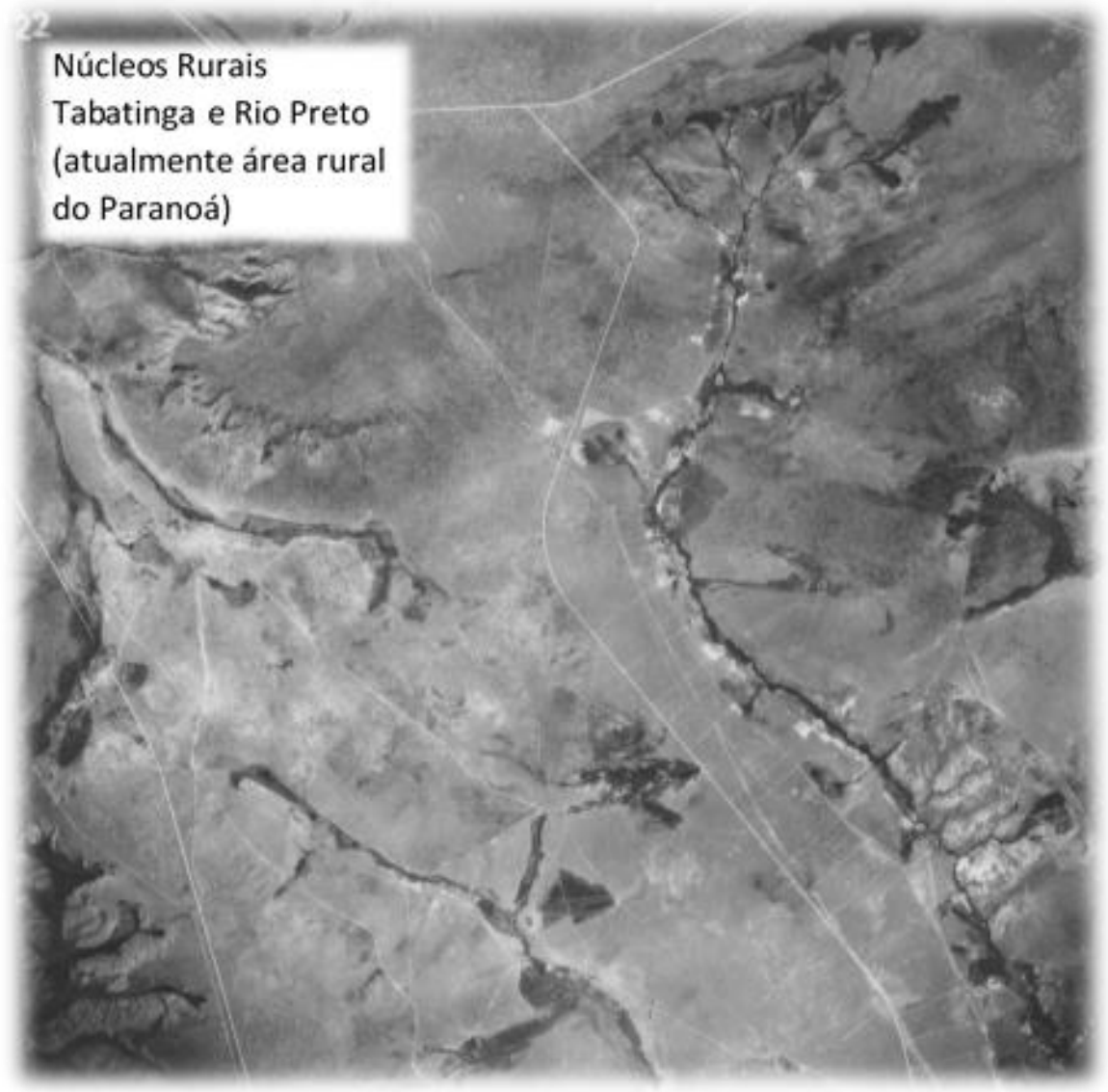

Figura 18: Região de Tabatinga e Rio Preto.

Fonte: http://www.sedhab.df.gov.br/preservacao-e-planejamento-urbano/gestao-da-informacaourbanas/mapas.html 
A figura 18 (1965), mostra as primeiras divisões de glebas e estradas na região dos núcleos rurais de Tabatinga e Rio Preto, ainda em implantação. Pébayle os denominava de 'Núcleos rurais de agricultores e de criadores de gado'.

Outra questão importante definida para as áreas rurais foi a preocupação com a pesquisa. No início da construção de Brasília, nas terras da Fazenda Sucupira, na atual área do Riacho Fundo, o Ministério da Agricultura criou o Centro de Laboratório e Pesquisa de Zootecnia. Atualmente esta área está sob responsabilidade da EMBRAPA.

A Fundação Zoobotânica do Distrito Federal criou "Granjas-Modelo" especialmente, para dar suporte alimentar aos habitantes da nova capital. Duas dessas granjas ficavam localizadas na região que, hoje, pertence ao Riacho Fundo: as GranjasModelo: Ipê e Riacho Fundo. As fábricas da Granja Ipê produziam banha e doces diversos, enquanto na Granja Riacho Fundo, criavam-se suínos, bovinos e coelhos. Em todas as granjas, havia uma vila residencial para os funcionários.

\section{B. Aspectos Ambientais}

Em 1961 é criado o Parque Nacional de Brasília, (decreto 241 de 29/11/61). Visa a preservação ambiental e o Manancial de Santa Maria responsável pelo abastecimento de grande parte do Plano Piloto. A indefinição de seus limites corroborou com ocupações irregulares.

Em 1966, com a implantação do Código sanitário do DF, foram estabelecidas diretrizes para o meio ambiente e saneamento. Ele delimita a contenção da ocupação urbana na bacia do Paranoá. As áreas rurais nesta área foram importantes elementos para este fim.

Outra delimitação ambiental importantíssima definida neste período é a Reserva Biológica de Águas Emendadas (Dec.771 de 12/08/68). No local de criação da reserva se localizam as nascentes de importantes bacias hidrográficas brasileiras além de ecossistemas relevantes para o cerrado.

Embora o Relatório Belcher tenha considerado a área abundante de recursos hídricos, o Distrito Federal está localizado em um platô, no qual situam-se os divisores 
das bacias do Paraná, São Francisco e Amazônica, com drenagens de pequeno porte e rios pouco caudalosos (SILVEIRA, 1999, p.111) Portanto, a Reserva Biológica de Águas Emendadas é uma importante e estratégica área de preservação de interesse nacional. Infelizmente vem sofrendo impactos das ocupações urbanas e rurais nas imediações.

\section{Aspectos Sociais}

Com a contínua migração para trabalhar nos canteiros de obras e o consequente aumento populacional, novas satélites foram criadas. $\mathrm{O}$ povoamento do Gama prossegue em conformidade com o projeto do governo, que visou à erradicação dos assentamentos formados pelos trabalhadores operários da construção de Brasília. Foram transferidas para o Gama, famílias das Vilas Amauri, Vila Planalto e o Setor de Indústrias de Taguatinga.

Para Freitas (2009) o controle do processo de migração estava implícito no projeto do Plano Piloto de Lúcio Costa da década de 50. O projeto previa que somente após a consolidação do núcleo original (cujos limites foram estabelecidos em torno de 500 mil habitantes), é que surgiriam outras cidades. Esta recomendação baseava-se na possibilidade de contenção do incremento populacional resultante de processos migratórios. Apostava no retorno da enorme massa de trabalhadores da construção civil para seus locais de origens. Isto porque não se admitiu a ocupação do Plano Piloto com os trabalhadores.

À revelia da estratégia de planejamento segregador, outros nucleamentos urbanos foram surgindo neste período: o Núcleo Bandeirante (Cidade Livre), a Candangolândia e o Paranoá. A figura 19 ilustra as diferenças entre uma área comercial planejada no Gama e residências precárias em lotes exíguos no Núcleo Bandeirante. 


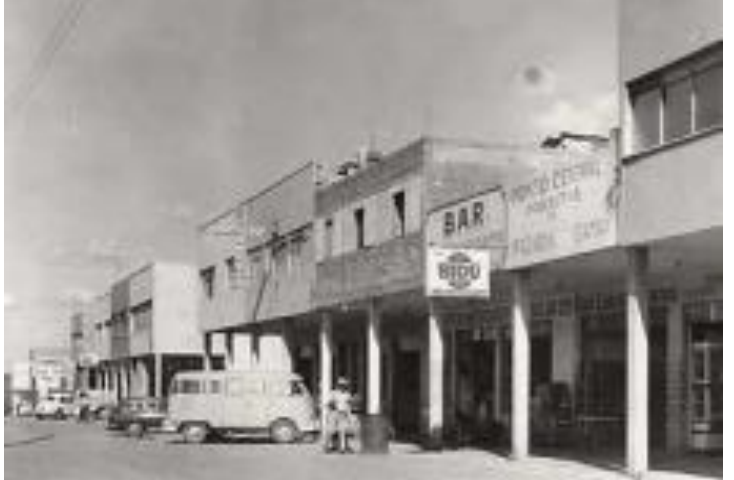

a)

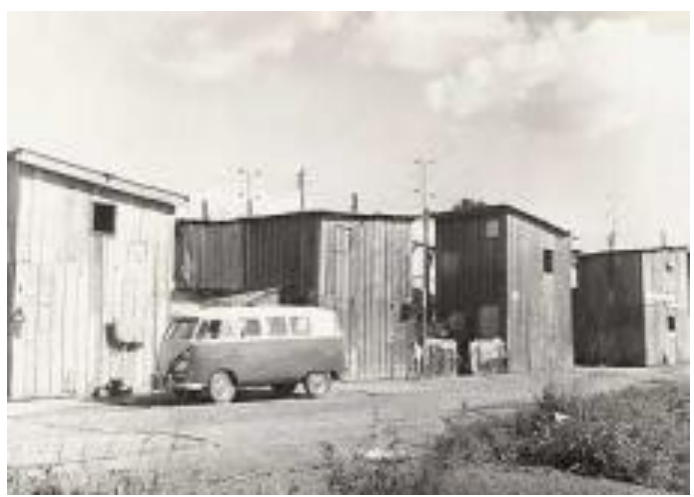

b)

Figura 19: (a): comércio central da cidade satélite do Gama e, (b) Núcleo Bandeirante (NB) com residências de barracos de dois pisos em lotes exíguos (junho de 1971)

(Fonte: http://www.vitruvius.com.br/revistas/read/minhacidade/07.074/1940 - Aldo Pavani

Próximo ao Plano Piloto, o Park Way fora uma estratégia de lotear áreas rurais em grandes lotes residenciais $\left(2500 \mathrm{~m}^{2}\right)$ para venda. Foi uma das últimas alterações incluídas no Plano urbanístico de Brasília.

Conforme pode ser verificado na figura 20 , os nucleamentos urbanos que tiveram projetos elaborados para assentar a população migrante - Taguatinga, Sobradinho e Gama - foram definidos afastados do plano piloto. O polinucleamento definido no período correspondia a uma segregação planejada da população de baixa renda.

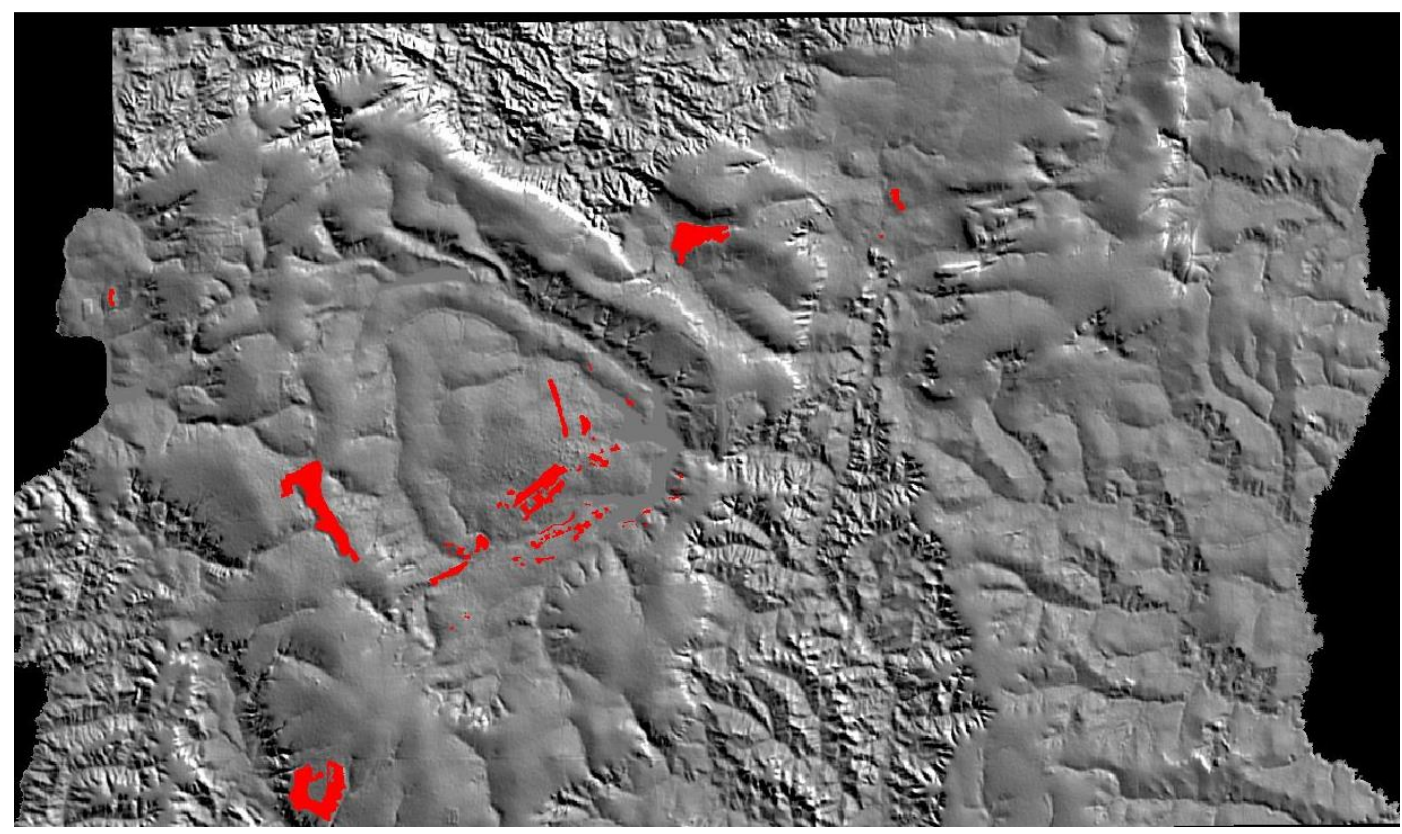

Figura 20 Ocupação urbana em 1964. (Fonte: SEDUH) 
A ocupação urbana, planejada de forma dispersa no território, transformava as áreas rurais entre os núcleos urbanos em potenciais áreas de expansão urbana.

\section{Aspectos Espaciais}

Nesta primeira década foram criados instrumentos jurídicos visando seguir com o processo de controle do território. 0 dec. 04 de 10/05/60 dispõe sobre a divisão do Território do DF para efeito de fiscalização e rendas públicas. A lei 5.364 de 1967, autoriza a NOVACAP a alienar lotes rurais de sua propriedade no DF. Em 1967, o decreto 203 regulamentado pelo Dec. Local 636/67, visa dar prosseguimento ao processo de desapropriação de terras no DF.

Em relação à estrutura urbana, a lei 5.545 de 1964 cria a organização administrativa do DF com a primeira divisão física do território em Regiões Administrativas (RA I a RA VIII). E em 1965, a Lei 4766 reforça esta ocupação territorial polinucleada.

Mas é o decreto 1052 de 1969 que definia as áreas rurais do DF:

a) Área Metropolitana - compreendida pela bacia formadora do Rio Paranoá circunscrita pela Estrada Parque Contorno (EPCT). Fica dentro dos limites da chamada faixa sanitária e constitui as áreas urbanas que integram o Plano Urbanístico de Brasília;

b) Áreas das Cidades-satélites e,

c) Área Rural que abrange toda a superfície restante.

$\mathrm{O}$ decreto especificava o tratamento dado às áreas rurais. Na periferia dos centros urbanos de Brasília, dentro da Área Metropolitana, poderiam ser criados loteamentos de Chácaras para exploração hortigranjeira. As glebas da área rural seriam distribuídas em lotes rurais indivisíveis de acordo com planos elaborados pela Secretaria de Agricultura e Produção do Distrito Federal. Os lotes rurais deveriam ser explorados pelo sistema de arrendamento, com prazo de 30 anos. As áreas mínimas e máximas de cada lote rural seriam determinadas pelas condições geofísicas e hídricas de cada loteamento combinadas com as atividades a serem nelas desenvolvidas. 0 arrendamento estaria condicionado a apresentação do Plano de Exploração do lote. 
Os lotes rurais agrícolas, destinados ao desenvolvimento de atividades agropecuárias, eram classificados nos seguintes grupos:

a) Lotes hortigranjeiros - atividades hortícolas ou criação de aves ou animais de pequeno porte;

b) Lotes para agropecuária - áreas de terra destinadas a exploração intensiva de produtos agrícolas básicos, fruticultura, produção leiteira e aproveitamento industrial com utilização dos recursos da própria gleba.

c) Lotes industriais - destinados exclusivamente a transformação dos recursos animais, vegetais, produzidos por terceiros, bem como à extração de produtos do subsolo;

d) Áreas para reflorestamento - destinadas ao cumprimento da Lei no. 4771, de 15 de setembro de 1965.

e) Áreas especiais - destinadas "a pesquisa experimental, estudos ou exploração de culturas que exijam tratamento especial.

Os Núcleos Rurais eram formados pelos conjuntos compostos de todos os lotes rurais acima. Na periferia dos Núcleos Rurais podiam ser criados loteamentos compostos de pequenos lotes, para fins residenciais, em número não superior ao total de lotes rurais existentes no respectivo Núcleo, com área máxima de dois mil metros quadrados. Estes pequenos lotes seriam destinados a agricultores que não tivessem condições econômicas para arrendar ou explorar a área.

\subsection{Síntese do período}

Nestas primeiras décadas de implantação e existência de Brasília, seu território não é mais polarizado por uma economia agrícola incipiente. A força exercida pela implantação da capital da república faz com que se altere a lógica de uso e ocupação do solo. As áreas rurais e os antigos núcleos urbanos são agora regidos pelo funcionamento da nova capital.

Muitos advindos do campo, vieram para a construção da cidade. A migração ruralurbana, explícita neste período da história brasileira, é reforçada com a implantação da nova capital da República. 
Outro elemento que é reforçado neste período é a ocupação polinucleada com a criação das cidades satélites. Ironicamente essa nova população urbana, oriunda do êxodo rural, é novamente segregada.

As áreas rurais, externas à área delimitada pela Estrada Parque Contorno (EPTC), exercem importante papel neste período de contenção da expansão urbana e preservação da área tombada. Porém, a ocupação urbana, dispersa no território, transformava as áreas rurais entre os núcleos urbanos em potenciais áreas de expansão urbana.

Braslândia e Planaltina ficaram isoladas do processo de construção da Capital, uma vez que sua localização era afastada das principais vias de acesso. Não houve crescimento urbano e a dinâmica de ocupação de suas áreas rurais permaneceram inalterada neste primeiro momento, exceto as fazendas que foram alagadas para a implantação da represa do Rio Descoberto.

Apesar da consolidação da produção agrícola de alguns núcleos rurais - como é o caso de Vargem Bonita - os objetivos de abastecimento agrícola não foram alcançados em sua totalidade. A proximidade do Plano Piloto e, a existência de infraestrutura como estradas e rede elétrica, atraiu o interesse de funcionários públicos e outros moradores da área urbana, transformando algumas áreas em chácaras de lazer e outros fins, desvirtuando o uso inicial de exploração agrícola. Corroboraram também a ausência de critérios de seleção de arrendatários, a falta de fiscalização no uso das parcelas, excessiva liberalidade nas transferências de arrendamento e a valorização imobiliária dessas áreas com a consolidação de Brasília e de sua área urbana. (SILVEIRA, 1999, p. 201)

Ainda neste período, a desapropriação inconclusa já causava conflitos no processo fundiário. Projetos de ocupação agrícola, como o núcleo rural Alexandre Gusmão (Braslândia), são exemplos destes conflitos, na indefinição da titularidade da terra. Interessante notar também que já havia um processo de ocupação irregular de chacareiros em Vicente Pires.

Os gráficos da figura 21 apresentam uma quantificação das primeiras alterações na paisagem original do cerrado (1954) com a implantação da nova capital. No gráfico de 1964 as alterações no meio natural são observadas com a diminuição de áreas de 
matas, cerrado e campos, a presença de solo exposto e, o consequente aumento de áreas urbana e agrícola. Porém esta última ainda é incipiente neste período. Nota-se variação significativa nos corpos d'água, provavelmente devido à implantação das barragens do Descoberto e Paranoá.

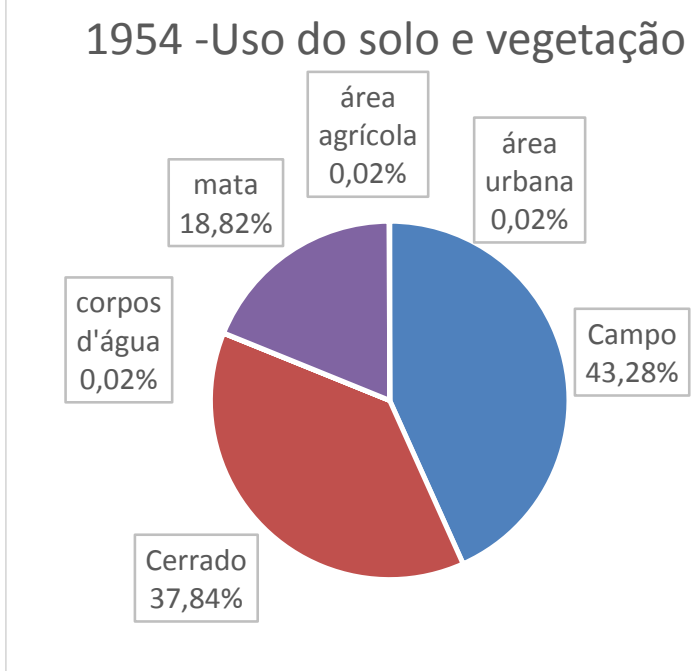

a)
1964 -Uso do solo e vegetação

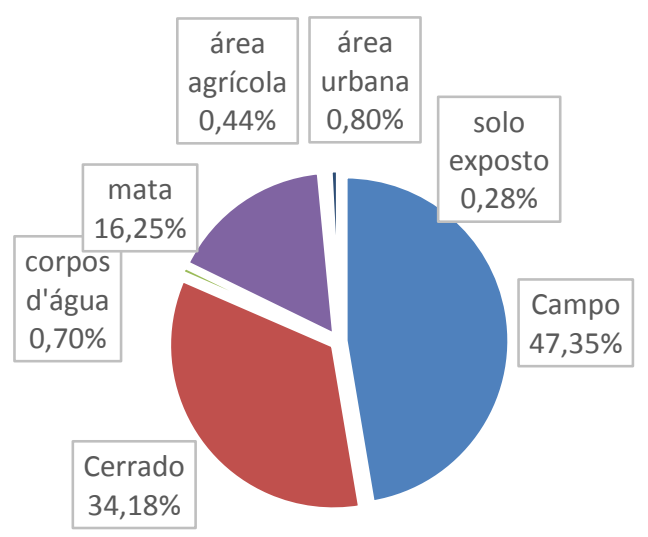

Figura 21: Gráficos de uso do Solo elaborados à partir de material da UNESCO (2002) sobre uso do solo e vegetação no DF

O desenho esquemático da figura 22 , busca trazer elementos relevantes do período por áreas de análise.

Em relação à questão social aponta as cidades pré-existentes (Brasilândia e Planaltina) e os núcleos urbanos que surgiram no período (Sobradinho, Gama, Taguatinga, Plano Piloto, Núcleo bandeirante/Cidade Livre, Candangolândia e Paranoá. Na questão ambiental, delimita as áreas ambientais que surgiram no período - Águas Emendadas e Parque Nacional. Em relação ao critério espacial, importante delimitador das áreas rurais do período é a Estrada Parque Contorno (EPCT).

Dentre as áreas rurais estão delimitadas no mapa aquelas mais relevantes e características do período. Antecedentes: Vargem Bonita e Vargem da Benção. Na década de 60 destacam-se: Alexandre Gusmão, Vicente Pires, Taguatinga, Sobradinho, Vargem Bonita, Tabatinga e Rio Preto. Ainda merecem destaque as granjas modelos e fazenda Sucupira no Riacho Fundo. 


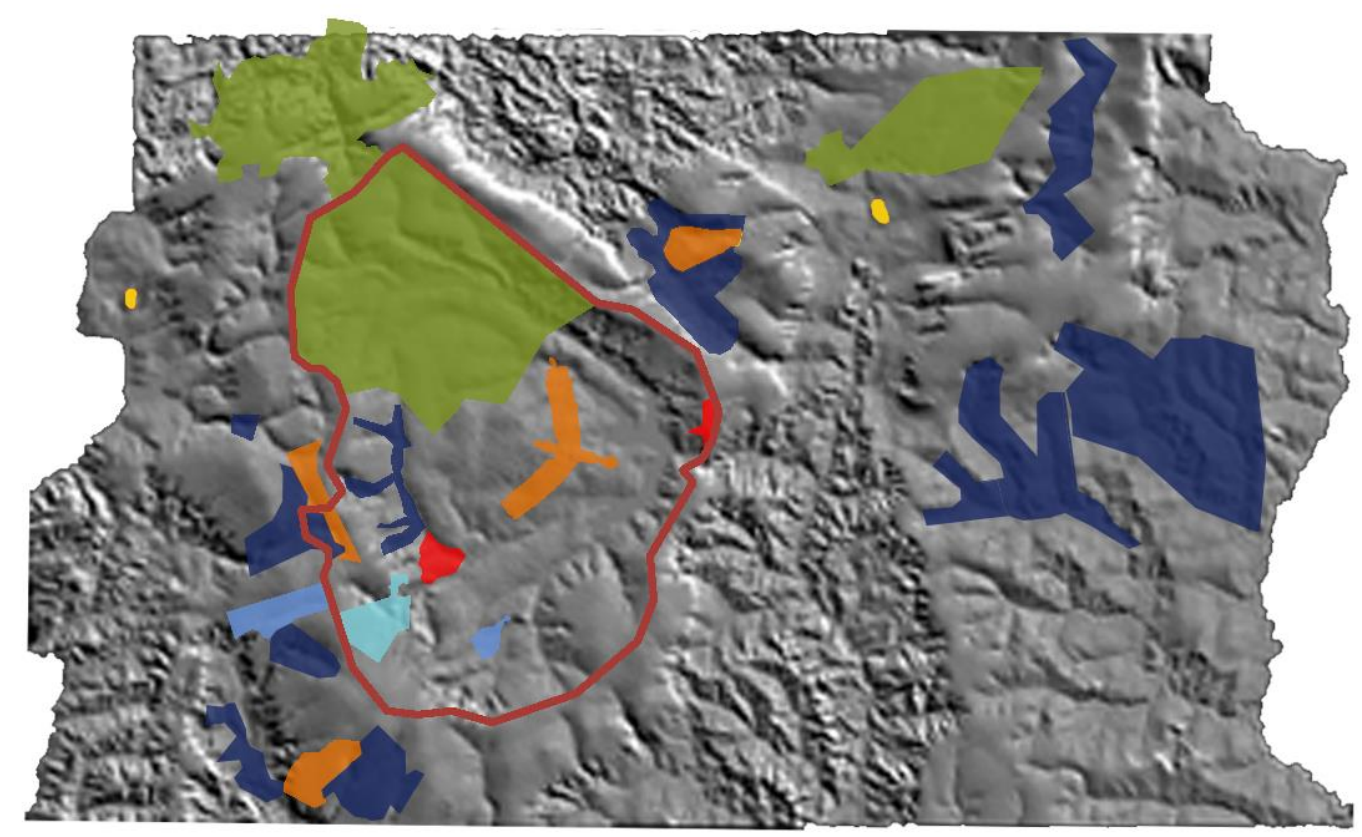

Década de 60

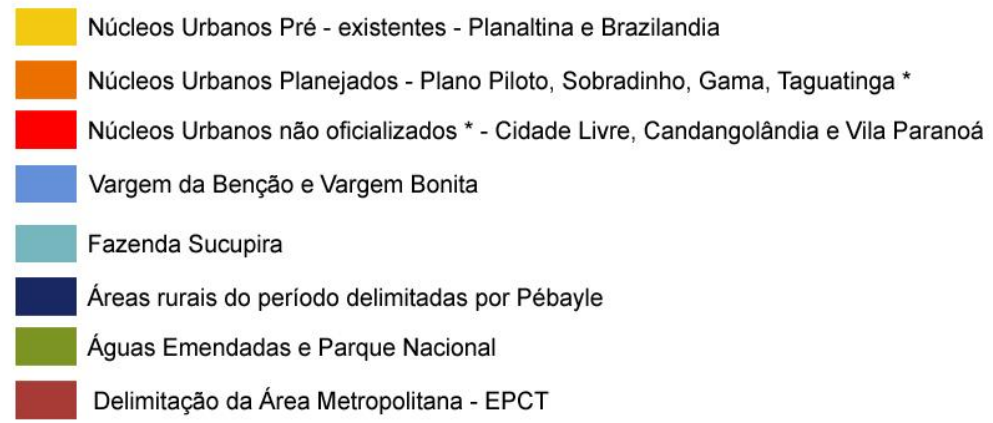

*As delimitações dos Núcleos Urbanos correspondem aos perímetros atuais e não ao do período.

Figura 22: Desenho esquemático da localização de alguns dos principais elementos do período levantados nas categorias de análise. (Mapa base: SEDHU). 
Quadro 5: Síntese - Antecedentes e década de 1960,

\begin{tabular}{|c|c|c|c|}
\hline Aspectos Econômicos & Aspectos Ambientais & Aspectos Sociais & Aspectos Espaciais \\
\hline $\begin{array}{l}\text { - Loteamentos rurais de } \\
\text { produção agrícola para } \\
\text { abastecimento da Capital; } \\
\text { - Sistema de posse sem } \\
\text { propriedade - concessão de } \\
\text { uso; } \\
\text { "Granjas-Modelo"; } \\
\text { - Áreas rurais do período } \\
\text { (Pébayle): } \\
\text { 1.Núcleos rurais dos } \\
\text { roceiros, } \\
\text { 2.Núcleos rurais de } \\
\text { agricultores e de criadores } \\
\text { de gado, } \\
\text { 3.Horticultores de vargem } \\
\text { bonita e Taguatinga, } \\
\text { 4.Núcleos rurais dos } \\
\text { "citadinos-chacareiros", } \\
\text { 5.Mutações das fazendas } \\
\text { tradicionais de criação de } \\
\text { gado, } \\
\text { 6.Os pequenos invasores } \\
\text { rurais. }\end{array}$ & $\begin{array}{l}\text { Relatórios Cruls e Belcher: } \\
\text { - Importantes estudos } \\
\text { ambientais } \\
\text { - pouca umidade, } \\
\text { - suscetibilidade do solo a } \\
\text { processos erosivos } \\
\text { - cuidado com os recursos } \\
\text { hídricos - rios pouco } \\
\text { caudalosos. } \\
\text { 1961 - Parque Nacional de } \\
\text { Brasília - proteção manancial } \\
\text { Santa Maria; } \\
\text { 1968 - Reserva Biológica de } \\
\text { Águas Emendadas; }\end{array}$ & $\begin{array}{l}\text { - Migração para construção } \\
\text { da Capital; } \\
\text { - Braslândia e Paranoá - pré- } \\
\text { existentes; } \\
\text { - Cidades Satélites projetadas } \\
\text { - Gama, Sobradinho e } \\
\text { Taguatinga; } \\
\text { - Nucleamentos - Cidade } \\
\text { Livre, Candangolandia e Vila } \\
\text { Paranoá; }\end{array}$ & $\begin{array}{l}\text { - Especulação na área da } \\
\text { futura capital; } \\
\text { - Desapropriação } \\
\text { inconclusa - dificuldade de } \\
\text { mapear fazendas; } \\
\text { - Áreas rurais definidas fora } \\
\text { da área metropolitana } \\
\text { delimitada pela EPCT. }\end{array}$ \\
\hline
\end{tabular}




\title{
4. ÁREAS RURAIS DO DF AO LONGO DO TEMPO - CONSOLIDAÇÃO
}

\begin{abstract}
Esta etapa foi denominada de 'consolidação' por compreender as duas décadas, de 1970 e 1980, posteriores à implantação. Aborda processos de consolidação da Capital, na qual sobressaem a agricultura mecanizada com ênfase na grande produção e projetos habitacionais para baixa renda avançando sobre áreas rurais.
\end{abstract}

\subsection{Década de 1970}

\section{A. Aspectos Econômicos}

Em 1971 foi implementado o Plano Agropecuário do Distrito Federal. Objetivava elevar a produtividade das áreas rurais do DF mediante políticas de recuperação, conservação e aumento da fertilidade do solo além de indicar caminhos e objetivos para melhorar a atividade rural no DF.

Ponto interessante do plano era sua articulação regional com órgãos de planejamento e institutos de pesquisa. Para melhorar a produtividade das áreas rurais, - Plano agropecuário passou a contar com a implantação de assessoria técnica de órgãos como Emater e Embrapa.

Em 1972, foi criada a Empresa Brasileira de Pesquisa Agropecuária (EMBRAPA). Em convênio firmado com a Fundação Zoobotânica obteve a Granja Tamanduá para desenvolvimento de pesquisas. No local atualmente se encontra o Centro Nacional de Recursos Genéticos (CENARGEN). Na figura 23, as imagens da Fazenda Sucupira, ilustram áreas de lavoura no período (1986). 


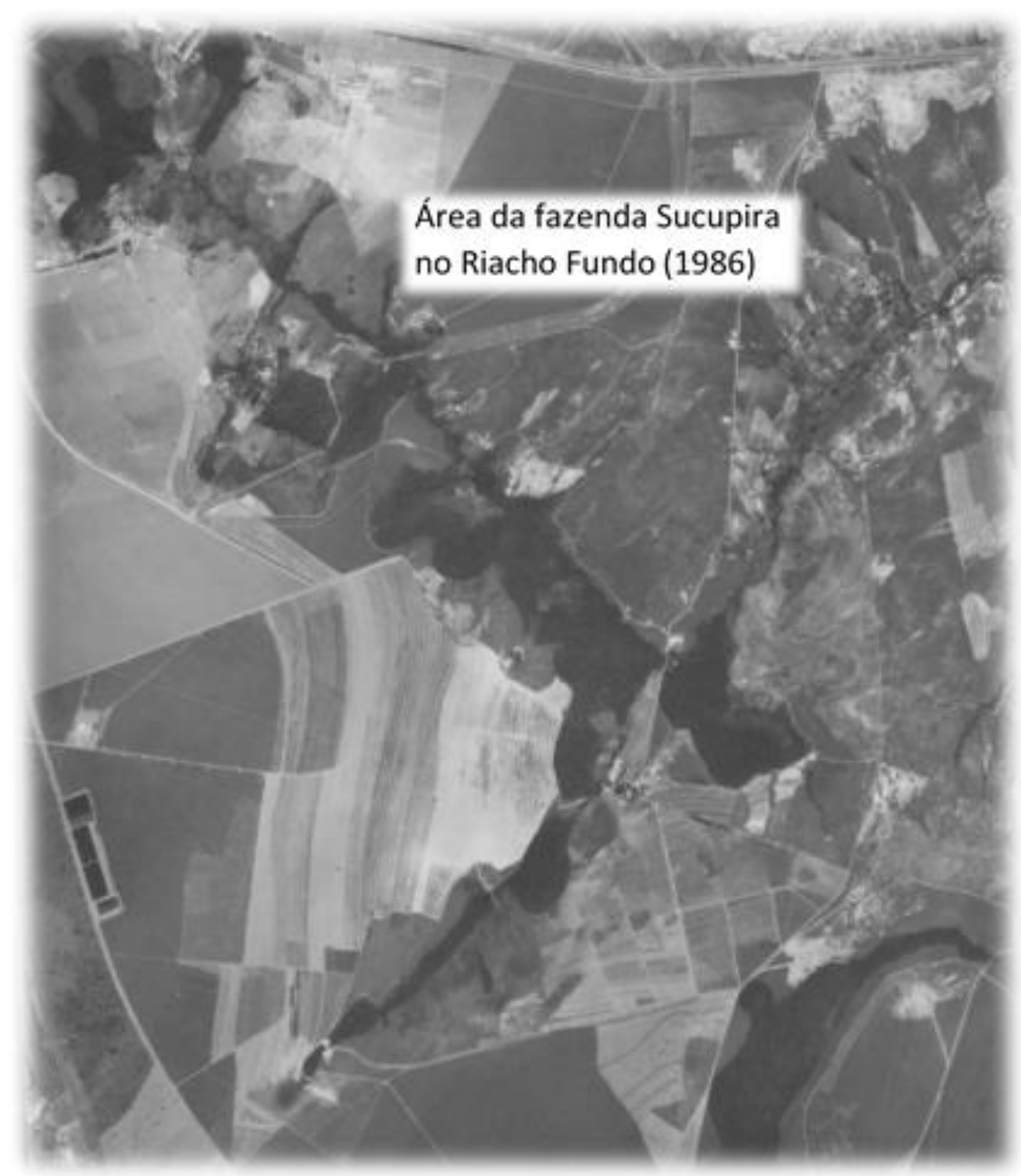

Figura 23: Foto de 1986 com a área da Fazenda Sucupira (atualmente área da EMBRAPA), Granjas Ipê e Riacho Fundo. (Fonte: http://www.sedhab.df.gov.br/preservacao-e-planejamento-urbano/gestao-da-informacaourbanas/mapas.html)

Nesse mesmo ano, foi criada a CEASA do DF - empresas de sociedade anônima, denominada Central de Abastecimento S/A - para auxiliar na comercialização de produtos in natura.

Ainda em 1972, foi criada a Florestamento e Reflorestamento S/A (PROFLORA), empresa vinculada à Secretaria de Agricultura e Produção, que recebeu uma área de 16.500 hectares destinada à implantação de 19 projetos de florestamento com eucaliptos (58\%), pinheiros (35\%) e mangueirais (7\%), tendo sido utilizados recursos provenientes de incentivos fiscais existentes à época. Em função de uma má 
administração, a PROFLORA chegou à situação de insolvência e entrou em processo de liquidação, no ano de 1990 (TAVARES, 1995).

Nesta década, é transferido para Brasília, o Instituto Nacional de Imigração e Colonização - atual Instituto Nacional de Colonização e Reforma Agrária (INCRA). Ficou sob sua responsabilidade a área de 22.000 hectares da Antiga Colônia Agrícola Alexandre Gusmão. Junto com a Vargem Bonita, foram os primeiros produtores de hortifrutigranjeiros no DF (TAVARES, 1995).

A fim de corrigir as distorções ocorridas no início do processo de ocupação das áreas rurais, iniciou-se, em 1974, um processo de seleção dos arrendatários. O Decreto 2.739 de 1974 estabelecia o sistema de arrendamento de terras nas áreas rurais e sua normatização. A área rural definida no Plano Diretor teria seu Plano de Ocupação, coordenado pelos técnicos da Fundação Zoobotânica (FZDF), ouvidos o Conselho de Arquitetura e a CAESB:

Nas periferias das cidades satélites poderão ser criados Núcleos Rurais, com loteamentos para exploração hortigranjeira, passíveis de arrendamento. Esses loteamentos deverão ser aprovados pela secretaria de Viação e Obras. Estabelece que os Núcleos Rurais serão distribuídos em lotes rurais, destinados preferencialmente ao desenvolvimento de atividades agropecuárias e Clubes campestres. Os lotes rurais serão classificados em: hortigranjeiros, agrícolas, pecuários, industriais, áreas para reflorestamento e áreas especiais. (SILVEIRA, 1999, p. 200)

À partir de 1977 a distribuição da terra em estabelecimentos maiores passou a ocorrer por meio da legalização das Áreas Isoladas. Os Núcleos Rurais perderam espaço para as Colônias Agrícolas, com lotes cada vez menores visando criar reserva de mão de obra para as grandes explorações. O incremento da produtividade da terra e o apoio à produção levou ao aumento da demanda por terras rurais e à aceleração da especulação imobiliária. (CODEPLAN, 2015)

Em 1977 foi implementado o Programa de Assentamento Dirigido do Distrito Federal - PAD-DF voltado para a produção de grãos e com características distintas das propostas anteriores para as áreas rurais. Buscava-se atrair empresários rurais, com o viés de produção em larga escala e o emprego de modernização agrícola. Localizado na Bacia do Rio Preto, o PAD-DF objetivava incorporar ao processo produtivo áreas rurais do Distrito Federal, até então inteiramente inexploradas. 
O Programa abrangeu uma área de 61.000 hectares, contemplando diversos projetos de atividade econômica, de acordo com suas características de relevo e aptidão agrícola, sendo as áreas distribuídas para o plantio de cereais, cultivo de hortifrutigranjeiros, bovinocultura, avicultura, etc. Dividia-se em Colônias Agrícolas com o objetivo de reassentar as famílias de agricultores locais e assentar famílias de produtores rurais oriundas do sul do país, além de áreas destinadas a produção intensiva. Também foram criados nessas colônias nucleamentos 'urbanos' providos de escola, área comunitária, posto de saúde, campo de futebol, quadras de esportes e lotes para moradia, no intuito de prover as áreas rurais de mão de obra.

A implementação do PAD-DF traz outros rumos para a produção agrícola com a implantação de uma agricultura empresarial, mecanizada e com uma produção de grãos voltada para um mercado externo. Esse modelo de produção contrasta com o preconizado na implantação do DF onde a produção agrícola deveria abastecer o mercado interno.

Até 1976, apenas $15 \%$ dos lotes praticavam uma agricultura de nível empresarial. O governo proveu as grandes unidades rurais de infraestrutura, crédito e tecnologia, visando desenvolvimento de uma agropecuária inserida no mercado. Além da infraestrutura viária, da eletrificação rural, os empresários rurais arrendatários contaram também com serviços de mecanização da Fundação Zoobotânica do DF. Foi também construída infraestrutura de armazenagem e o sistema viário secundário. Tanto nas terras arrendadas, quanto nas particulares, a ocupação se baseou na capacidade financeira, reproduzindo-se no DF a penetração capitalista presente na agropecuária nacional. (CODEPLAN, 2015).

\section{B. Aspectos Ambientais}

No intuito de controlar a ocupação da área planejada e buscando a preservação dos recursos hídricos da Bacia do Paranoá, definiu-se uma faixa sanitária delimitada pela Estrada Parque Contorno (EPCT) restringindo a ocupação urbana próximo ao Plano Piloto. A restrição ao crescimento urbano devido a fatores ambientais é 
enfatizada no PLANIDRO, de 1970 (Pano Diretor de Água, Esgoto e Controle da Poluição do Distrito Federal) e nas legislações ambientais subsequentes.

Dentre os fatores ambientais, talvez os recursos hídricos tenham sido os principais elementos definidores da ocupação espacial. O PLANIDRO foi um dos principais segregadores espaciais com a delimitação do não adensamento na bacia do Paranoá:

O critério aparentemente ordenador foi o de empurrar, ao máximo, as cidades satélites a serem criadas para fora da Bacia do Paranoá, num esforço pragmático e consciente de que assim poderiam ser preservadas certas características do meio ambiente natural da bacia, sob iminente risco de serem transformadas, e sobretudo as instancias institucionais (preservadas das pressões produzidas por populações carentes e operários, pela presença muito próxima do poder). (IPEA, 2002, p.111)

Os Planos de Ordenamento Territorial que se sucederam não conseguiram orientar e disciplinar a ocupação do território nas áreas rurais e de preservação ambiental pela expansão urbana.

As características físicas do sitio 'Castanho' do Relatório Belcher foram decisivas para a definição do local de implantação do Plano Piloto. Porém as definições de localização das demais regiões administrativas pela NOVACAP não seguiram os mesmos critérios técnicos de ordem ambiental. A desconsideração de fatores naturais em projetos urbanísticos nas antigas áreas rurais acarretou processos erosivos, como os que ocorreram em Samambaia e Vila Buritis em Planaltina.

\section{Aspectos Sociais}

Neste período há uma consolidação da capital federal com a estrutura urbana poli nucleada, refletindo uma forte segregação sócio espacial. 'Vivia-se a fase de erradicação de áreas de invasões e de crescimento das cidades satélites.' (IPEA, 2001, p.50). A cidade de Ceilândia surge à partir da Campanha de Erradicação de Invasões (CEI), realizada em 1971 pelo Governo do DF.

Porém, na década de 1970, surge o primeiro parcelamento urbano irregular do Distrito Federal: "Condomínio Quintas da Alvorada". Segundo a TERRACAP, o 
parcelamento não despertou grande interesse da população, devido à falta de infraestrutura e pelo fato da população possuir à época inúmeras alternativas de moradia regular no mercado imobiliário de Brasília e nas demais cidades do DF'

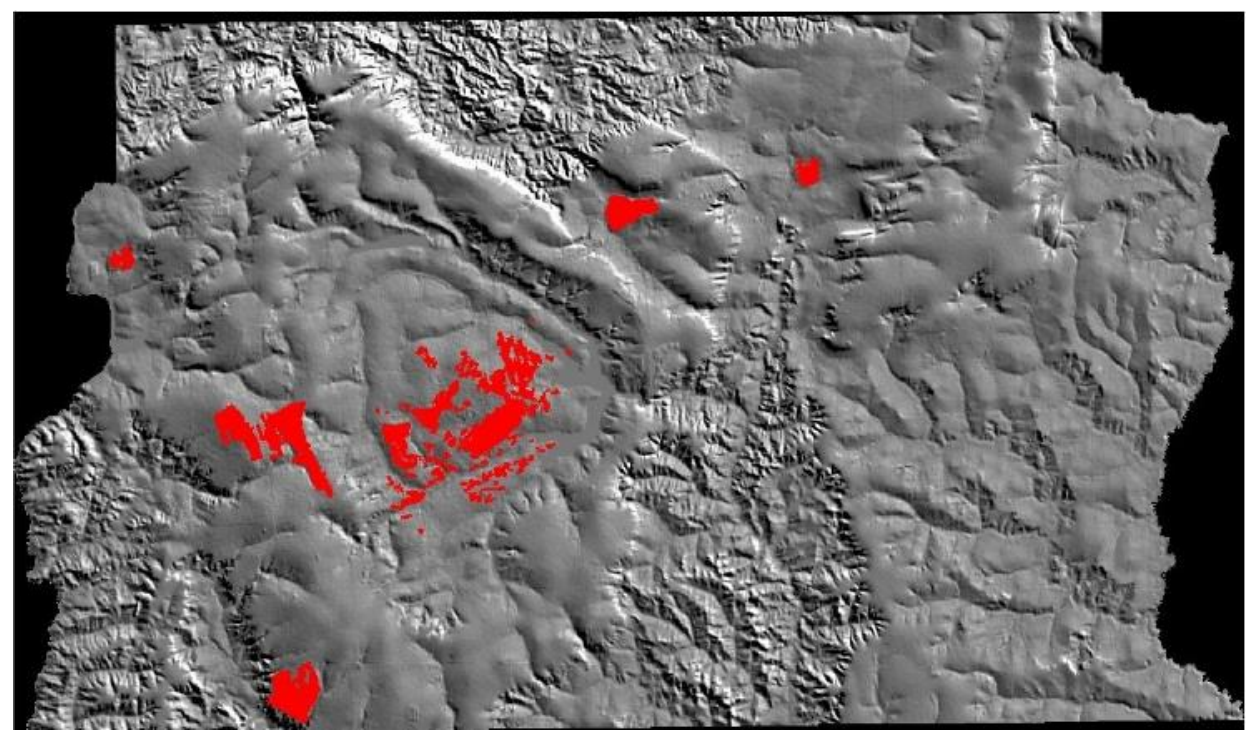

Figura 24: Ocupação urbana em 1973. (Fonte: SEDUH)

As políticas adotadas neste período não foram suficientes para atender as demandas por moradia no Distrito Federal, oriundas dos processos migratórios. Como consequência, as cidades do entorno imediato tiveram redução de suas áreas rurais devido à expansão urbana para fins de moradia. Merece destaque Luziânia que posteriormente vai originar Valparaíso, Novo Gama e Cidade Ocidental.

\section{Aspectos Espaciais}

A Lei 5.861/1972 revogou a proibição da alienação de terras rurais a pessoas físicas ou jurídicas de direito privado e criou a TERRACAP que absorveu parte das funções da NOVACAP. Permitiu ainda o arrendamento de vários lotes rurais por um único arrendatário, a criação das Áreas Isoladas para implantação de grandes projetos agropecuários e a entrega de pequenos lotes para fixação de mão-de-obra rural. 
Em 1974 instituiu-se o PERGEB - Programa Especial para a Região Geoeconômica de Brasília. Visava o desenvolvimento social e econômico da região, preservar Brasília, fortalecer subcentros e evitar a migração intensiva. Estabelecia três áreas de ação: de dinamização (visando fomentar pólos de desenvolvimento nos municípios mais distantes); área intermediária (para controlar/ordenar o crescimento urbano); e a área de contenção (visando conter a proliferação de novos assentamentos no DF).

O decreto 2.739 de 16/10/74 estabelece o primeiro zoneamento para o território. Define competências quanto ao uso do solo rural e urbano e apresenta normas para o uso, concessão, distribuição e arrendamento das terras rurais do Distrito Federal. Já o Dec.3906 de 24/10/1977, dispõe sobre o licenciamento e a fiscalização de edificações na área rural do DF. Em seu artigo 1을 estipula que as edificações de qualquer natureza nas áreas rurais dependerão de prévia e obrigatória licença expedida pela Administração Regional onde se localizar o imóvel.

O PEOT - Plano Estrutural de Organização Territorial do DF (fig.25), homologado pelo Decreto n. 9 4.049, de 10 de janeiro de 1977, tinha como finalidade elaborar o ordenamento territorial do Distrito Federal. Buscava direcionar as áreas de expansão urbana no intuito de minimizar a estrutura urbana poli nucleada e desarticulada existente, diminuindo os custos sociais de transporte e infraestrutura. 


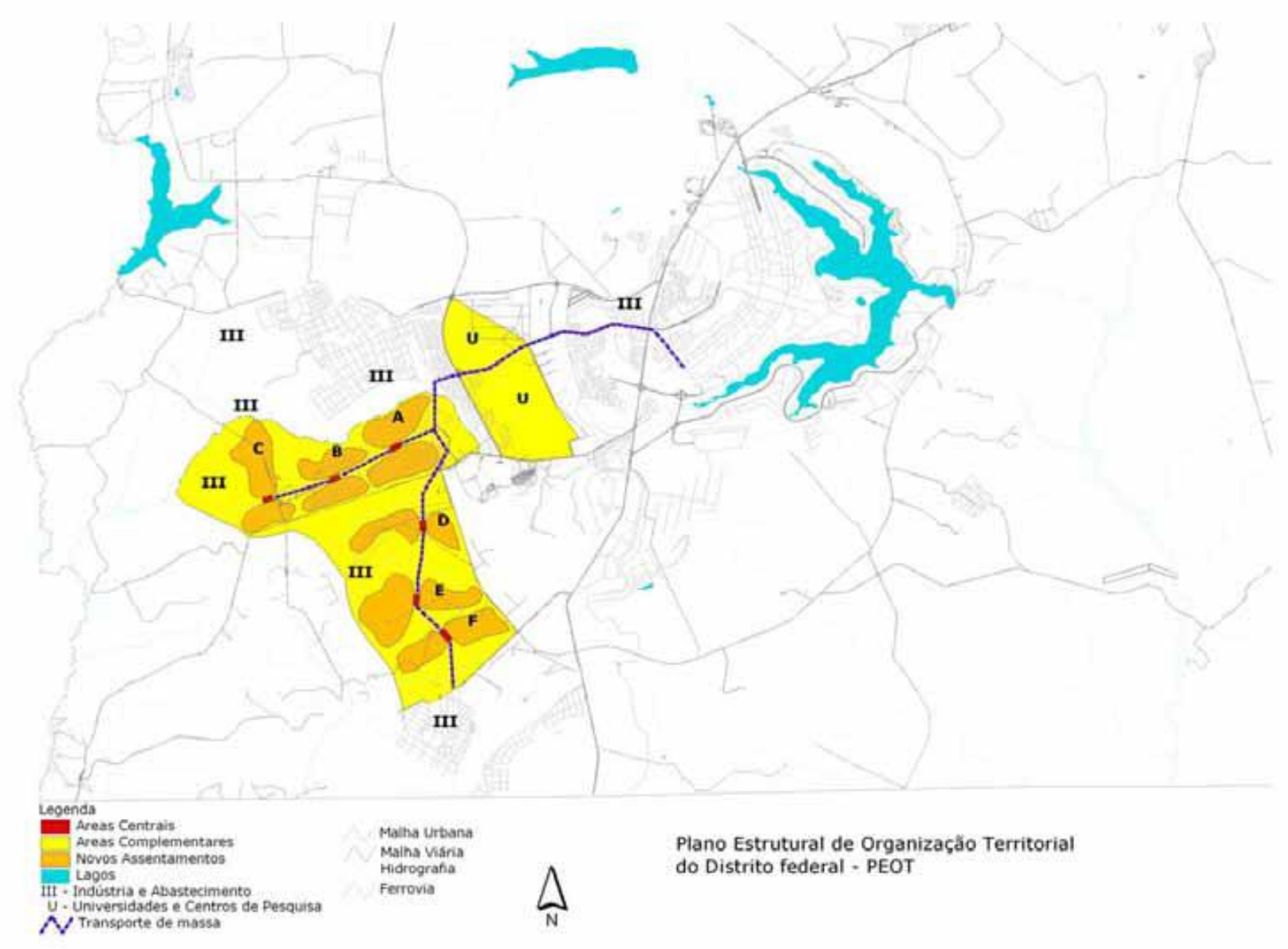

Figura 25: Plano Estrutural de Ordenamento Territorial - PEOT (Fonte:Mancini apud SEDUMA) 


\subsection{Década de 1980}

\section{A. Aspectos Econômicos}

O programa de estradas vicinais $(1980 / 83)$ no contexto de desenvolvimento socioeconômico, visava melhorar a estrutura viária por meio de estradas vicinais em Planaltina e Jardim, localidades mais isoladas e ocupadas por atividades rurais.

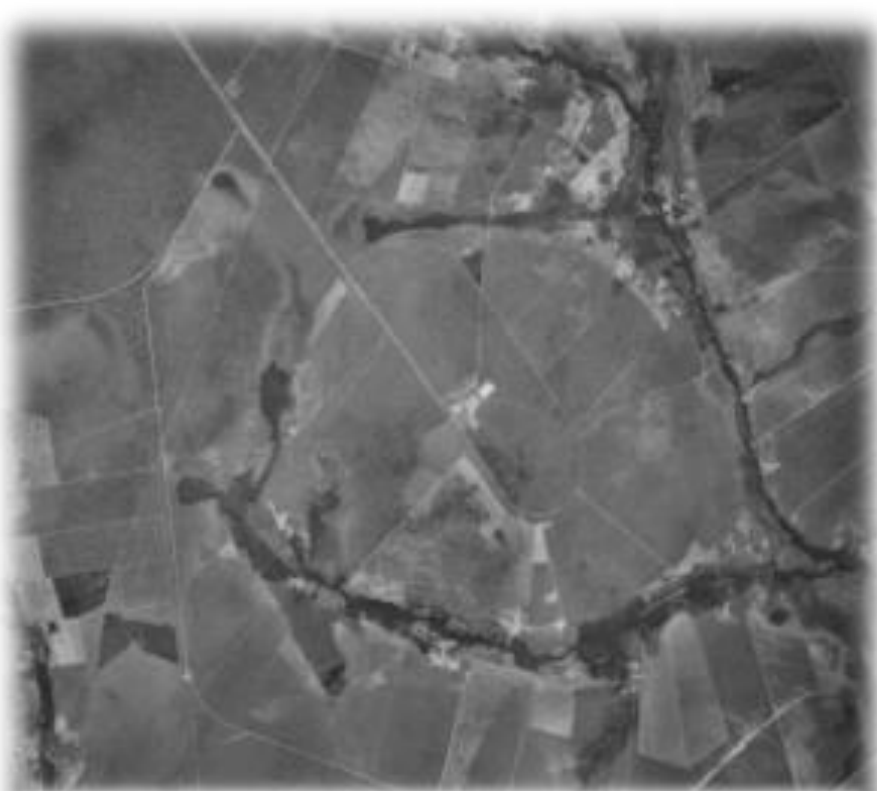

Núcleos Rurais Tabatinga e Rio Preto (1975)

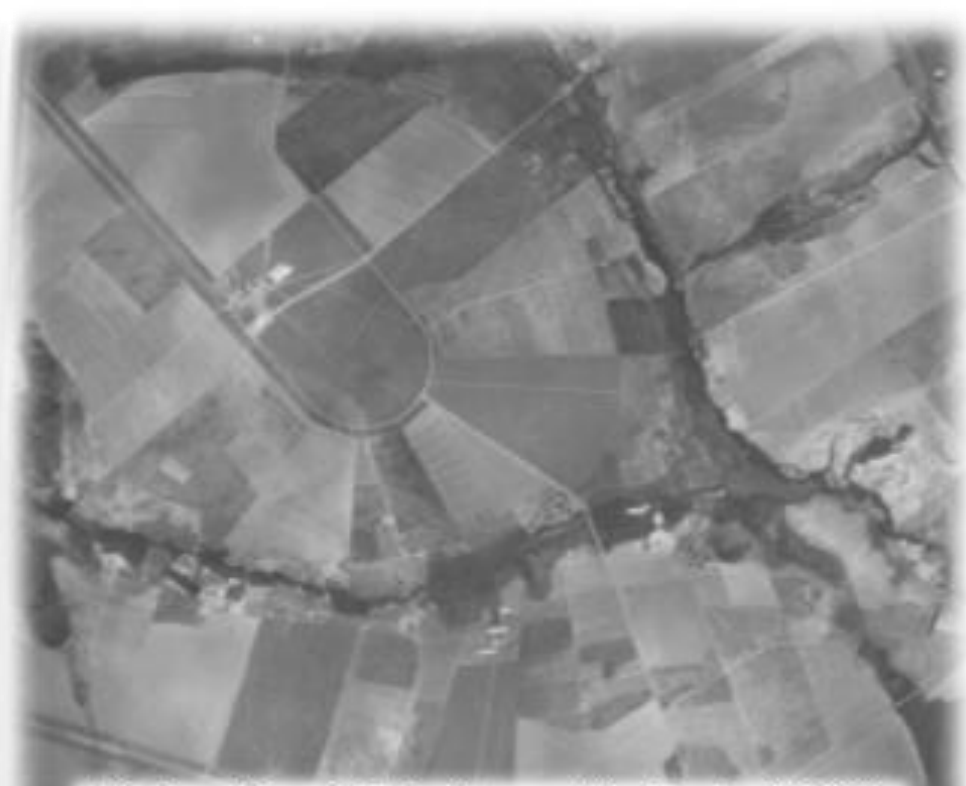

Núcleos Rurais Tabatinga e Rio Preto (1980)

Figura 26: Fotos de 1975 e 1980 mostrando a intensificação da ocupação rural nos núcleos Rurais de Tabatinga e Rio Preto. Fonte: http://www.sedhab.df.gov.br/preservacao-e-planejamento-urbano/gestao-da-informacaourbanas/mapas.html

Na figura 26 observa-se a melhoria nas estradas e um aumento da área de plantio nos núcleos rurais de Tabatinga e Rio Preto em Planaltina. A produtividade das figuras esboçam as políticas implementadas na década anterior e a melhoria das estradas vicinais.

Em relação às vias nas áreas rurais - como se pode observar por meio do programa de estradas vicinais - há uma preocupação com facilitar o escoamento da 
produção agrícola. Porém a disponibilidade de acesso às áreas rurais também atua como facilitador a outros tipos de ocupação como moradia e atividades de lazer/recreativas.

O dec.10024 de 22/12/86 Estabelece normas sobre distribuição, administração e utilização de terras nas áreas rurais do DF. Fala sobre a divisão da área rural e institui o sistema de Concessão de uso pelo prazo de 15 anos, admitindo-se renovação.

\section{B. Aspectos Ambientais}

Neste período merece destaque a implantação das Áreas de Proteção Ambiental (APAs) no Distrito Federal com intuito de proteção ambiental e regulamentação do uso do solo urbano e rural. O quadro 6 apresenta as APAs criadas neste período e a figura 27 sua localização.

Uma APA, de acordo com a legislação ambiental, é uma unidade de conservação de uso sustentável, cujo principal objetivo é compatibilizar a conservação da natureza com o uso de parcela de seus recursos naturais. As APAs são áreas geralmente extensas, com certo grau de ocupação humana, onde há interesse em preservar determinadas condições importantes para a qualidade de vida e o bem estar das populações humanas. Nessas áreas é necessário proteger a diversidade biológica, disciplinar a ocupação e assegurar a sustentabilidade dos recursos naturais. A ocupação e o uso do solo, nestas áreas, são determinados por um plano de gestão.

Sem fiscalização suficiente, as cinco APAS do DF não impediram a ocupação do solo por loteamentos irregulares. Um exemplo é a APA do São Bartolomeu que, embora exista no papel, não teve seu plano de manejo implementado. Sua criação não impediu a ocupação irregular do solo por loteamentos em áreas onde isso é totalmente proibido.

Outro elemento ambiental importante nesse período foi, em 1989 a regulamentação do EIA/RIMA (Lei 041 de 03/09/89, regulamentada pelo dec.1.2960 de 29/12/90, alterada pela lei 1.399 de 10/03/97). Define necessidade de EIA/Rima para 
ÁREAS RURAIS DO DF AO LONGO DO TEMPO - CONSOLIDAÇÃO

obras ou atividades potencialmente poluidoras. Porém carece de instrumentos governamentais de avaliação e monitoramento. 
Quadro 6: Detalhamento das APA's do DF.

\begin{tabular}{|c|c|c|c|c|}
\hline APA & CRIAÇÃO & ÁREA & ABRANGÊNCIA & OBJETIVOS \\
\hline $\begin{array}{l}\text { APA da bacia } \\
\text { do rio São } \\
\text { Bartolomeu }\end{array}$ & \begin{tabular}{|c} 
Decreto \\
Federal \\
88.940, de 7 \\
de novembro \\
de 1983 \\
(Administraçã \\
o transferida \\
ao DF em \\
1996) \\
\end{tabular} & $\begin{array}{c}84 \text { mil } \\
\text { hectares }\end{array}$ & $\begin{array}{l}\text { Bacia do rio São Bartolomeu (reúne todos os tipos de vegetação do } \\
\text { cerrado e representantes de diversas espécies da fauna local) }\end{array}$ & $\begin{array}{l}\text { Um de seus principais objetivos é ser um corredor de ligação entre } \\
\text { a Estação Ecológica de Águas Emendadas e as APAs de Cafuringa, } \\
\text { do Lago Paranoá e das bacias do Gama e Cabeça-de-Veado. }\end{array}$ \\
\hline $\begin{array}{l}\text { APA da bacia } \\
\text { do Rio } \\
\text { Descoberto }\end{array}$ & $\begin{array}{l}\text { Decreto } \\
\text { Federal } \\
88.940, \text { de } 7 \\
\text { de novembro } \\
\text { de } 1983\end{array}$ & $\begin{array}{l}39 \text { mil } \\
\text { hectares } \\
\text { envolvendo } \\
\text { DF e Goiás }\end{array}$ & $\begin{array}{l}\text { Bacia do Rio Descoberto. A maior parte de sua superfície é ocupada } \\
\text { por chácaras - originalmente voltadas à produção de } \\
\text { hortifrutigranjeiros -e por reflorestamento de pinus e eucaliptos. A } \\
\text { cidade de Brazlândia também está dentro dos seus limites. }\end{array}$ & $\begin{array}{l}\text { Visa à proteção da bacia do rio Descoberto e de sua represa, } \\
\text { responsável pela maior parte do abastecimento hídrico do DF. }\end{array}$ \\
\hline $\begin{array}{l}\text { APA das } \\
\text { bacias do } \\
\text { Gama e } \\
\text { Cabeça-de- } \\
\text { Veado }\end{array}$ & $\begin{array}{l}\text { Criada por } \\
\text { decreto } \\
\text { distrital em } \\
\text { abril de } 1986\end{array}$ & $\begin{array}{l}25 \text { mil } \\
\text { hectares (sul } \\
\text { do DF) }\end{array}$ & $\begin{array}{l}\text { Engloba grande parte do Lago Sul, Setor de Mansões Park Way, } \\
\text { Catetinho, Núcleo Rural Vargem Bonita e Aeroporto Internacional } \\
\text { de Brasília, e Candangolândia. Nela se encontram instituições de } \\
\text { pesquisa como a Estação Ecológica do Jardim Botânico, a Estação } \\
\text { Ecológica da Universidade de Brasília, a Reserva Ecológica do IBGE, } \\
\text { a Fazenda Experimental Água Limpa e o Jardim Zoológico. E } \\
\text { também o Santuário de Vida Silvestre do Riacho Fundo. }\end{array}$ & $\begin{array}{l}\text { Seu principal objetivo é proteger as cabeceiras e preservar as } \\
\text { drenagens do ribeirão do Gama e do córrego Cabeça-de-Veado, } \\
\text { responsáveis por um terço das águas do Lago Paranoá. }\end{array}$ \\
\hline $\begin{array}{l}\text { APA de } \\
\text { Cafuringa }\end{array}$ & $\begin{array}{l}\text { Criada por } \\
\text { decreto } \\
\text { distrital em } \\
\text { junho de } 1988\end{array}$ & $\begin{array}{l}46 \text { mil } \\
\text { hectares } \\
\text { (extremo } \\
\text { Noroeste do } \\
\text { DF) }\end{array}$ & $\begin{array}{l}\text { Engloba parte da Chapada de Contagem e da bacia do rio } \\
\text { Maranhão. Tem relevo acidentado e muitas cachoeiras, entre elas } \\
\text { alguns dos monumentos naturais mais bonitos do DF (Poço Azul, } \\
\text { Mumunhas, Morro da Pedreira e as cachoeiras do córrego Monjolo } \\
\text { e a Ponte de Pedra nas nascentes do ribeirão Cafuringa. Contém } \\
\text { ainda a maior parte das ocorrências de calcário do DF, abrigando } \\
\text { inúmeras cavernas, como a Gruta do Rio do Sal. }\end{array}$ & $\begin{array}{l}\text { Entre seus objetivos estão a proteção dos monumentos naturais e } \\
\text { do meio ambiente. A área é suscetível a processos erosivos devido } \\
\text { ao declive acentuado e tipo de solo. Apresenta processos de } \\
\text { ocupações semi-urbanas como o Lago Oeste. }\end{array}$ \\
\hline $\begin{array}{l}\text { APA do lago } \\
\text { Paranoá }\end{array}$ & $\begin{array}{l}\text { Criada por } \\
\text { decreto } \\
\text { distrital em } \\
\text { dezembro de } \\
1989 \\
\end{array}$ & $\begin{array}{c}16 \text { mil } \\
\text { hectares }\end{array}$ & $\begin{array}{c}\text { Abriga áreas urbanas do DF, caracterizadas como áreas de } \\
\text { adensamento populacional - Plano Piloto, Paranoá, Lago Sul e Lago } \\
\text { Norte. Atua como divisor de águas entre as Bacias do Paranoá e São } \\
\text { Bartolomeu. }\end{array}$ & $\begin{array}{c}\text { Proteger parte da Bacia Hidrográfica do Lago Paranoá, os ninhais de } \\
\text { aves aquáticas, a vegetação remanescente do Cerrado, a encosta } \\
\text { íngreme na parte Norte e as matas ciliares que protegem os } \\
\text { córregos e ribeirões, garantindo a qualidade das águas que } \\
\text { abastecem o Lago Paranoá. }\end{array}$ \\
\hline
\end{tabular}




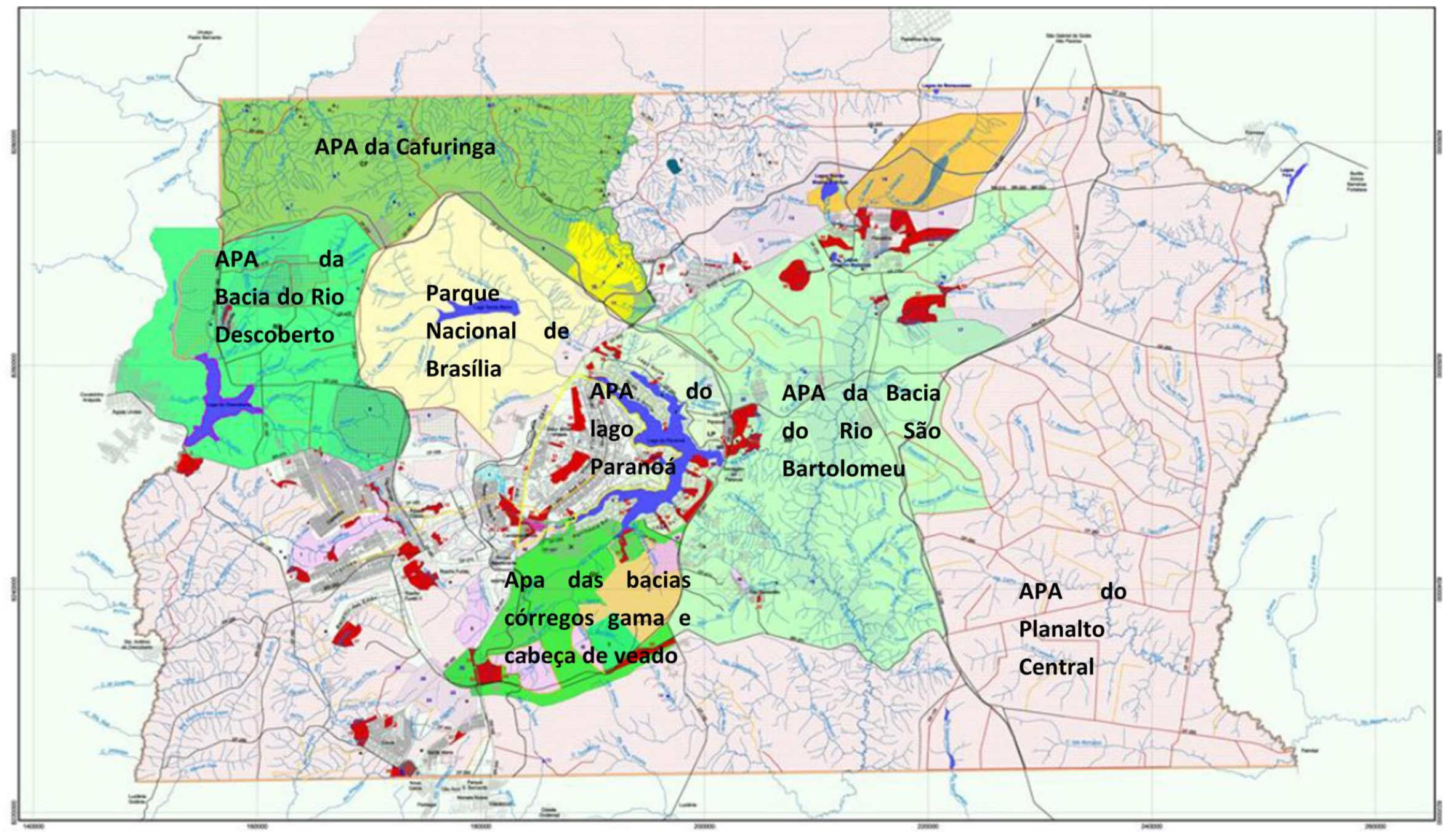

Figura 27: Localização das APAS do DF. (Fonte: termo de referência Paranoá, 2012) 


\section{Aspectos Sociais}

A falta de oferta governamental de habitação nesse período, culminou na urbanização de áreas rurais do entorno e a proliferação de assentamentos irregulares no Distrito Federal. No processo de expansão urbana, a ocupação das áreas rurais é acentuada ao longo dos principais eixos viários.

Em 1983 foi criado o GEPAFI - Grupo Executivo Para Assentamento de Favelas e Invasões. Propunha a urbanização de invasões, transferência de invasões para áreas vizinhas e para áreas residenciais previstas pelo PEOT. Atuou entre 1983 e 1985 fazendo levantamento e cadastramento das invasões existentes. Na época, 70 mil pessoas moravam em favelas e/ou invasões, conforme estudo do próprio GEPAFI. A política adotada propunha o assentamento das famílias no local (quando fosse possível), em áreas vizinhas ou em áreas residenciais previstas no PEOT. O principal foco era assentar populações de baixa renda em áreas urbanas.

A partir de 1986 buscou-se implementar o projeto combinado agrourbano (1986/88) em áreas públicas das granjas do Ipê e Riacho Fundo (figura 28). Visava, por meio da implantação de agrovilas, proporcionar moradia, trabalho e renda ao excedente da população de baixa renda. Propunha aliar loteamentos de exploração rural com serviços urbanos. O CAUB I, localizado na área rural do Riacho Fundo II-DF, era um modelo de reforma agrária implantado em 1986, com o intuito de tornar Brasília um pólo de produção de laranja. No projeto inicial, o CAUB I ocuparia as terras públicas da Granja do Ipê e do Riacho Fundo, através de glebas que se distribuiriam ao longo da Estrada Parque Ceilândia-Taguatinga. Em meados da década de 90, o projeto original foi abandonado pelo governo. Ocorreu um processo de descaracterização das atividades de agricultura, abandono das terras pelos produtores rurais devido à falta de incentivo e recursos e, vários episódios de parcelamento irregular, venda e invasões de terras públicas. (RIOS, 2014)

O resultado foi a criação de novos núcleos urbanos e a venda dos direitos de cessão de uso a especuladores. Serviu também para indicar um vetor de políticas habitacionais para o futuro governo: o assentamento da população excedente em áreas rurais para fins urbanos. 


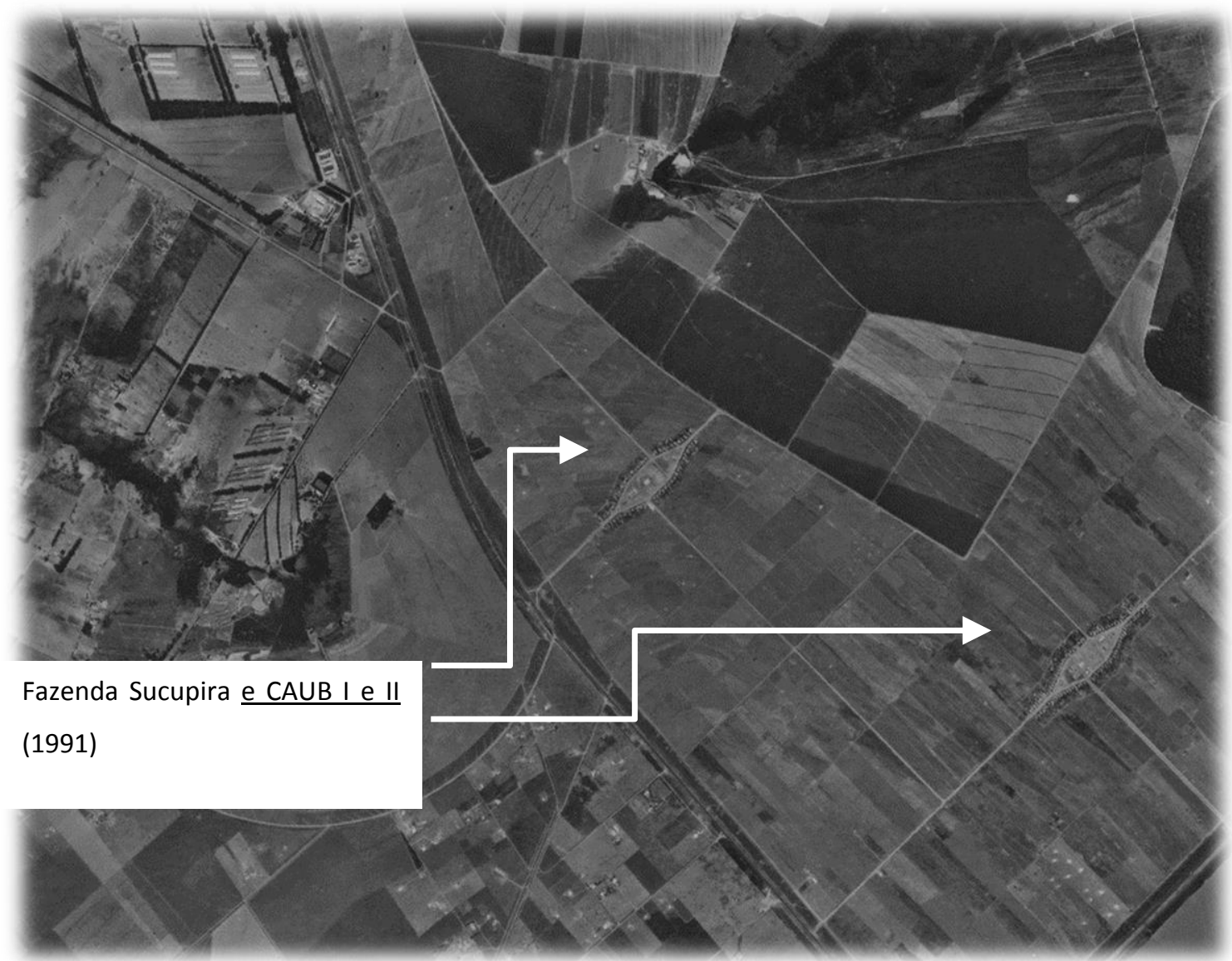

Figura 28: Foto de 1991 com a área da Fazenda Sucupira (atualmente área da EMBRAPA), e CAUB I e II. (Fonte: http://www.sedhab.df.gov.br/preservacao-e-planejamento-urbano/gestao-da-informacao-urbanas/mapas.html)
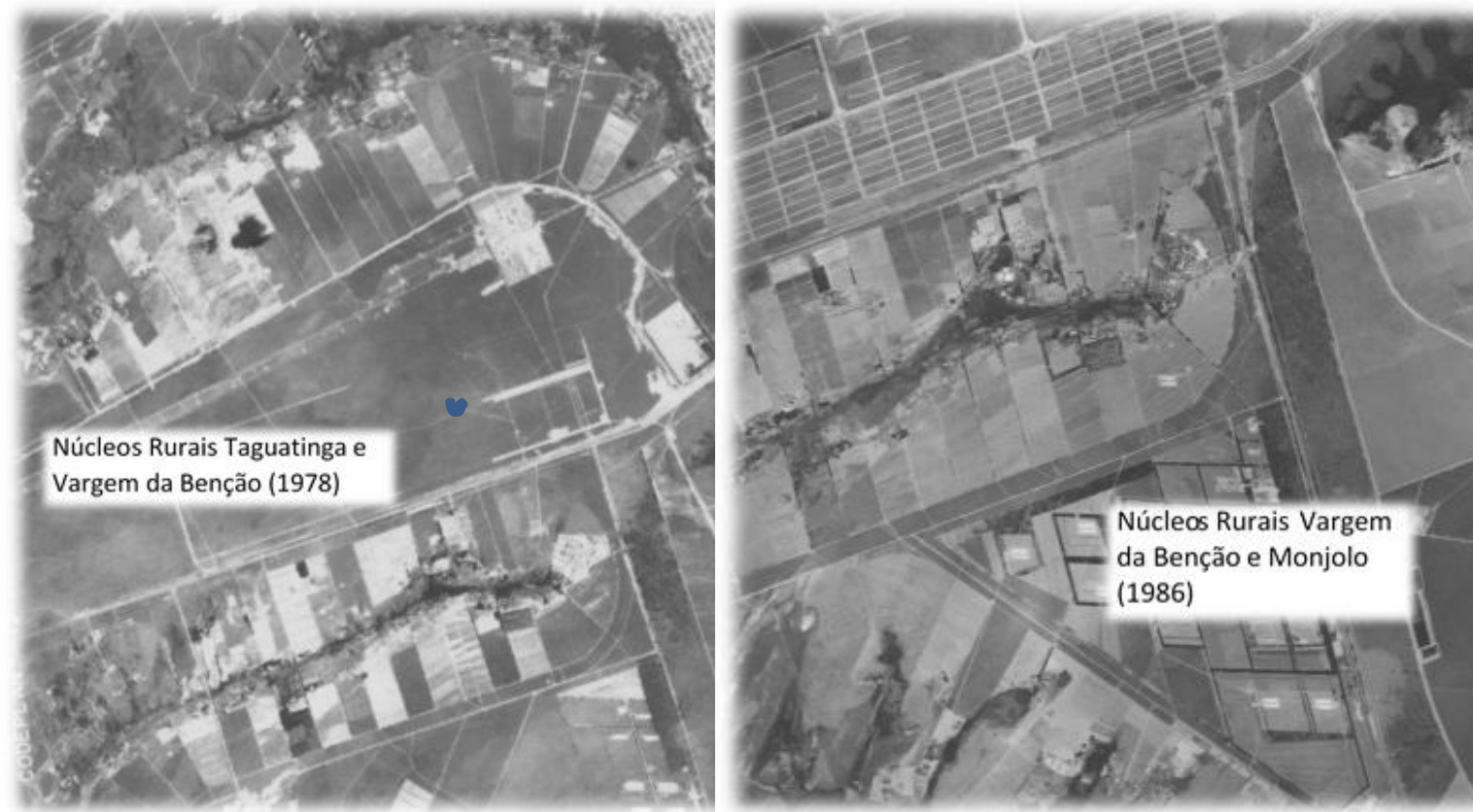

Figura 29: Fotos de 1978 e 1986 com os núcleos Rurais Taguatinga, Vargem da Bênção e Monjolo. ( 
Na figura 29, observa-se o avanço da ocupação urbana entre os núcleos rurais de Taguatinga, Vargem da Benção e Monjolo. Indica forte pressão de expansão urbana na região onde, neste mesmo período inicia-se a ocupação urbana do Recanto das Emas e Riacho Fundo.

São regularizados nesse período, no ano de 1989, as Regiões Administrativas do: Paranoá, Núcleo Bandeirante, Ceilândia, Guará e Samambaia.

A oferta regular de imóveis para moradia caiu sensivelmente na década de 1980, fazendo disparar os preços dos aluguéis e explodir as invasões em terras públicas. A solução habitacional para famílias de baixa renda eram as invasões. A classe média comprava lotes baratos em parcelamentos irregulares denominados "condomínios", a maior parte em zona rural.

Estudos para o ZEE apontam para o período quatro vetores de expansão na proliferação de assentamentos irregulares no DF: o nordeste (indo de Sobradinho e Sobradinho II a Planaltina ao longo do eixo viário da BR-020), o oeste (indo do Guará a Ceilândia ao longo das BR-060 e 070), o sudoeste (indo de Samambaia ao Gama e Santa Maria ao longo dos eixos viários da DF 001 e BR 040) e, o centro-sul (do Paranoá e Itapoã ao Setor Habitacional Tororó, ao longo dos eixos viários da DF 001 e DF 140).

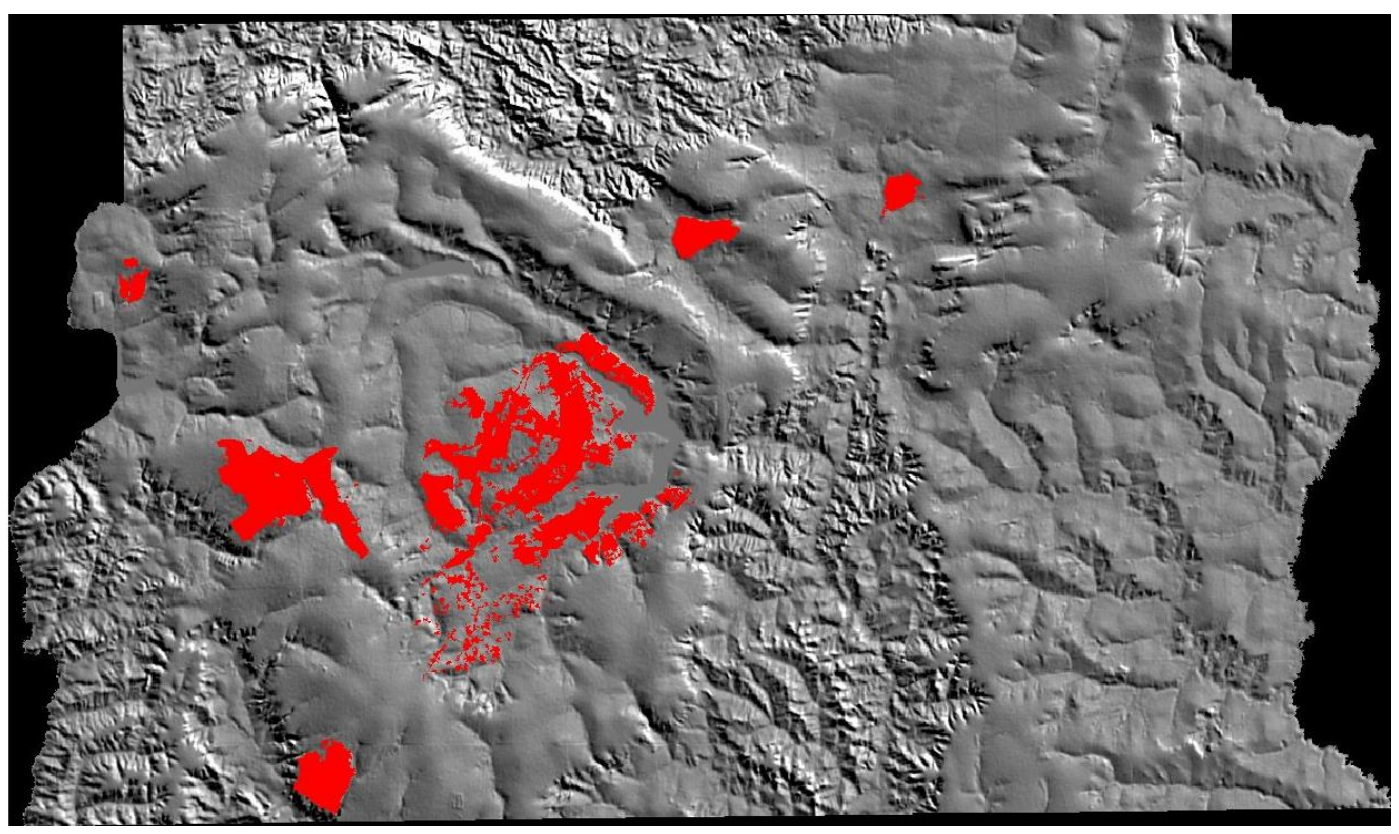

Figura 30: Ocupação urbana em 1984. (Fonte: SEDUH) 
Dando continuidade ao processo da década anterior, na década de 1980 houve um processo acelerado de urbanização das áreas rurais de municípios Goianos do entorno; principalmente nas cidades de Luziânia, Santo Antônio do Descoberto e Planaltina de Goiás. A resolução do problema de demanda habitacional pela população de baixa renda passa a ser transferida para outro Estado e para áreas rurais sem infraestrutura urbana. Há uma consequente valorização dessas terras e um processo de urbanização sem planejamento.

\section{Aspectos Espaciais}

Dados da extinta Fundação Zoobotânica do Distrito Federal (FZDF), apontam que no ano de $1981,52,4 \%$ da área rural do DF estava desapropriada em posse do GDF. Desse total, $26 \%$ estava em propriedade de posseiros, $3 \%$ foi privatizado pelo INCRA (Programa Integrado de Colonização Alexandre Gusmão) e 71\% sob a posse da FZDF. As áreas rurais na época estavam divididas em seis categorias: 57 áreas isoladas, 20 Colônias agrícolas, 15 núcleos rurais, 2 Combinados agrourbanos, 1 Projeto de Assentamento Dirigido - PAD/DF e, 1 Projeto Integrado de Colonização Alexandre Gusmão.

No tocante aos instrumentos de planejamento, o Plano de Ocupação Territorial do DF - POT (figura 31), de 1985, introduziu a proposta de macrozoneamento do território, definindo os diversos usos e o tipo de ocupação das zonas a serem criadas. O POT ratificou a tendência de expansão urbana levantada no PEOT e serviu de subsídio para os planos seguintes. Oficialmente não foi aprovado, o que dificultou sua aplicação.

O Plano de Ocupação e Uso do Solo - POUSO (figura 32), aprovado em 1986 e homologado em 1990, veio ratificar o POT. Redefiniu alguns pontos do macrozoneamento devido à transformações ambientais. 


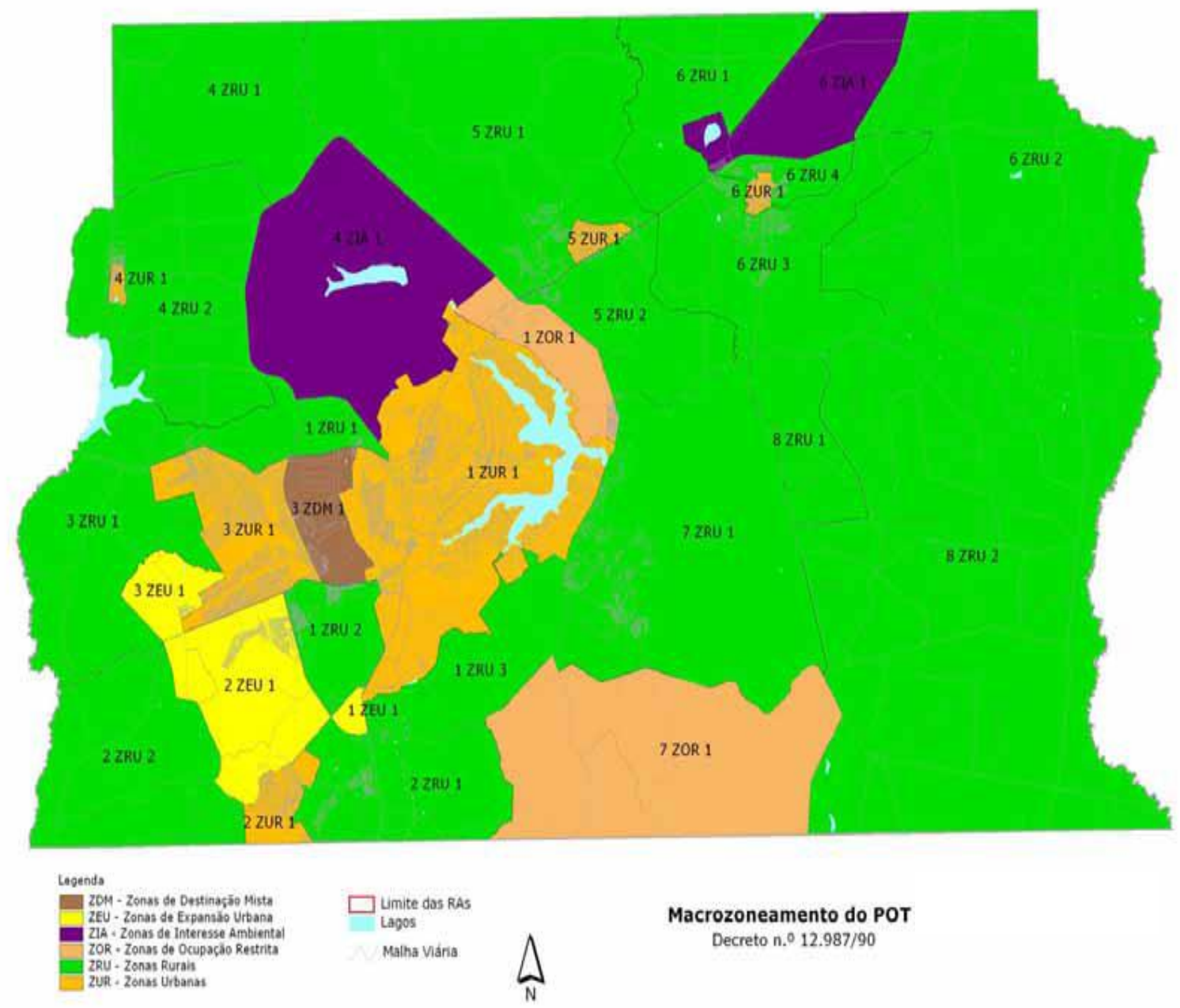

Figura 31: Plano de Ocupação Territorial do Distrito Federal - POT. (Fonte:Mancini apud SEDUMA) 


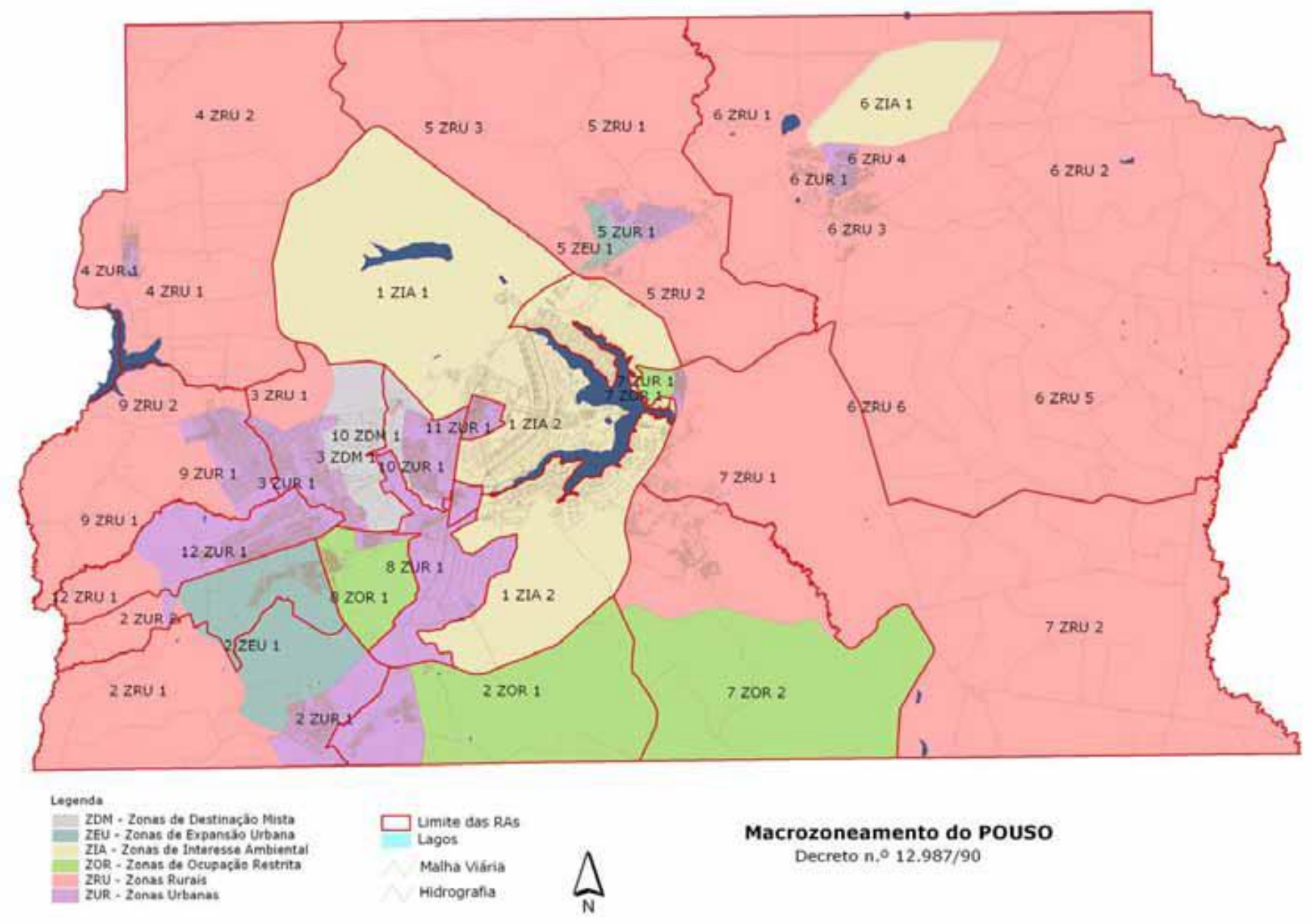

Figura -32: Plano de Ocupação e Uso do Solo - POUSO.

(Fonte:Mancini apud SEDUMA) 
Outro instrumento de planejamento do período foi o Brasília Revisitada (1985/87). Elaborada por Lucio Costa, define novas áreas residenciais na Bacia do Paranoá. Propõe adensamento urbano próximo ao Plano Piloto e expansão urbana ao longo dos principais eixos de ligação viária.

Os Planos elaborados neste período, ao introduzir o macrozoneamento, abordam o planejamento também no âmbito rural e ambiental. Isto pode ser observado nas categorias de uso: Zona Rural, Zona de Ocupação Restrita e Zona de Interesse Ambiental.

\subsection{Síntese do Período}

Na década de 1970, a implantação do Plano Agropecuário - articulado com órgãos de pesquisa (EMBRAPA e EMATER) para aumentar a produtividade das áreas rurais - e a criação do PAD-DF dão novos rumos para a produção agrícola do Distrito Federal.

A implantação do PAD-DF (1977), na zona rural do Paranoá, apresenta mudanças no cenário agrícola local. Surge um modelo de produção de grãos voltado para um mercado externo, com uma agricultura empresarial e mecanizada. Contrasta com o modelo de produção voltado para o abastecimento interno preconizado na implantação da Capital.

Outro ponto importante para as áreas agrícolas é a implantação do sistema viário secundário implementado nas áreas rurais facilitando o escoamento da produção. Inicia-se na década de 1970 e segue na década seguinte com o programa de estradas vicinais.

A criação da PROFLORA (1972) proporciona áreas de florestamento sem caráter de preservação ambiental. Não são árvores nativas do cerrado.

Os gráficos da figura 33 ilustram as principais políticas agrícolas do período. De uma década a outra, observa-se aumento considerável nas áreas agrícolas, o surgimento da área de reflorestamento e a diminuição das áreas de cerrado. 

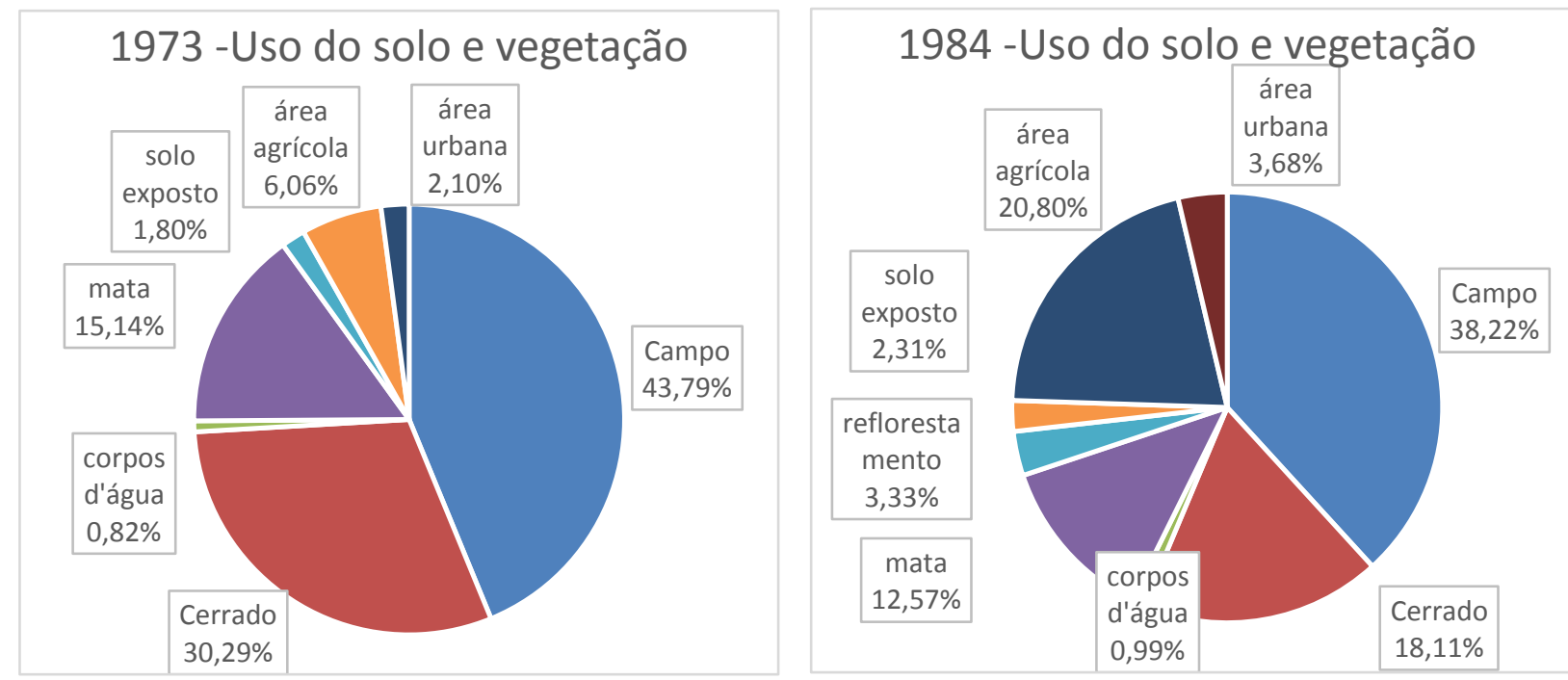

Figura 33: Gráficos de uso do Solo elaborados à partir de material da UNESCO sobre uso do solo e vegetação no DF (2002)

Em relação à questões ambientais as principais políticas do período são o PLANIDRO na década de 1970 e a criação das APAs na década de 1980.

A elaboração do PLANIDRO veio reforçar o controle da ocupação da Bacia do Paranoá (delimitada pela EPCT) e preservar os recursos hídricos da mesma. Se observa uma preocupação excessiva dessa área em detrimento do restante do Distrito Federal. A desconsideração de fatores naturais levou a processos erosivos como ocorreu em Samambaia.

Na década de 1980 foram criadas Áreas de Proteção Ambiental e a regulamentação do EIA RIMA. Trouxeram mais regulamentação para as áreas ambientais, porém apresentavam muitas dificuldades na sua implementação.

$\mathrm{Na}$ década de 70 surge o primeiro assentamento irregular em área rural: Quintas do Alvorada em Planaltina. Na década seguinte eles se proliferam e o governo cria o GEPAFI para controlar as invasões.

Na década de 1980 cai a oferta de imóveis para moradia. Consequentemente dispara o preço dos alugueis e proliferaram invasões culminando no processo de expansão de assentamentos irregulares. A tentativa de implementação do Combinado Agro Urbano envolvendo produção e moradia, na década de 1980, culminou com o desmembramento dos lotes. 
Outra consequência de a demanda por moradia não ser suprida pelas políticas públicas, é o aumento de loteamentos urbanos nas áreas rurais do entorno. São ocupadas áreas rurais em Luziânia, Santo Antônio do Descoberto e Planaltina de Goiás.

Neste período se consolida o polinucleamento das cidades enfatizando uma segregação sócio-espacial.

Em relação às políticas públicas no controle espacial, na década de 1970 temse: a criação da TERRACAP, o PERGEB como política para a região do entorno e o PEOT direcionando vetores de expansão urbana. Na década de 1980, o POT e posteriormente o POUSO, vem estabelecer macrozonas numa abordagem de planejamento envolvendo as áreas rurais e ambientais.

A figura 34 indica os nucleamentos urbanos do período, delimitações na ocupação urbana e inovações na política agrícola.

Em relação à política agrícola do período, são indicados o PAD-DF no Paranoá, a Granja Tamanduá, onde atualmente funciona a EMBRAPA Hortaliças, e áreas de reflorestamento da PROFLORA próximo à Braslândia.

Em relação à ocupação urbana, a EPCT, conforme estipulado no PLANIDRO, delimita/contém a ocupação urbana na Bacia do Paranoá. Porém nos vetores de expansão urbana indicados pelo PEOT, delineia-se um aumento da ocupação urbana e pressionando as áreas rurais locais (Taguatinga, Vargem da Bênção, Santa Maria...) 


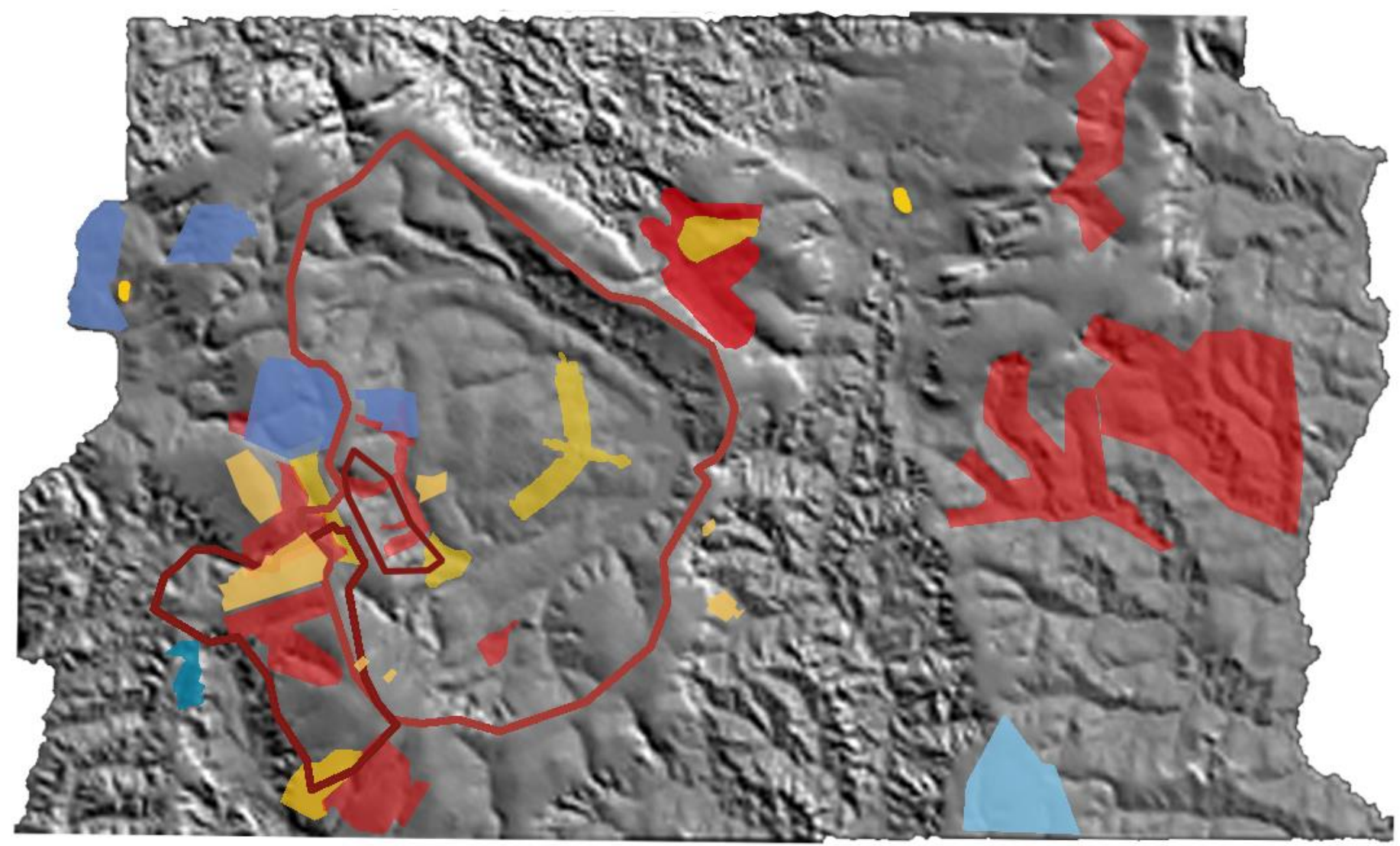

Década de 70

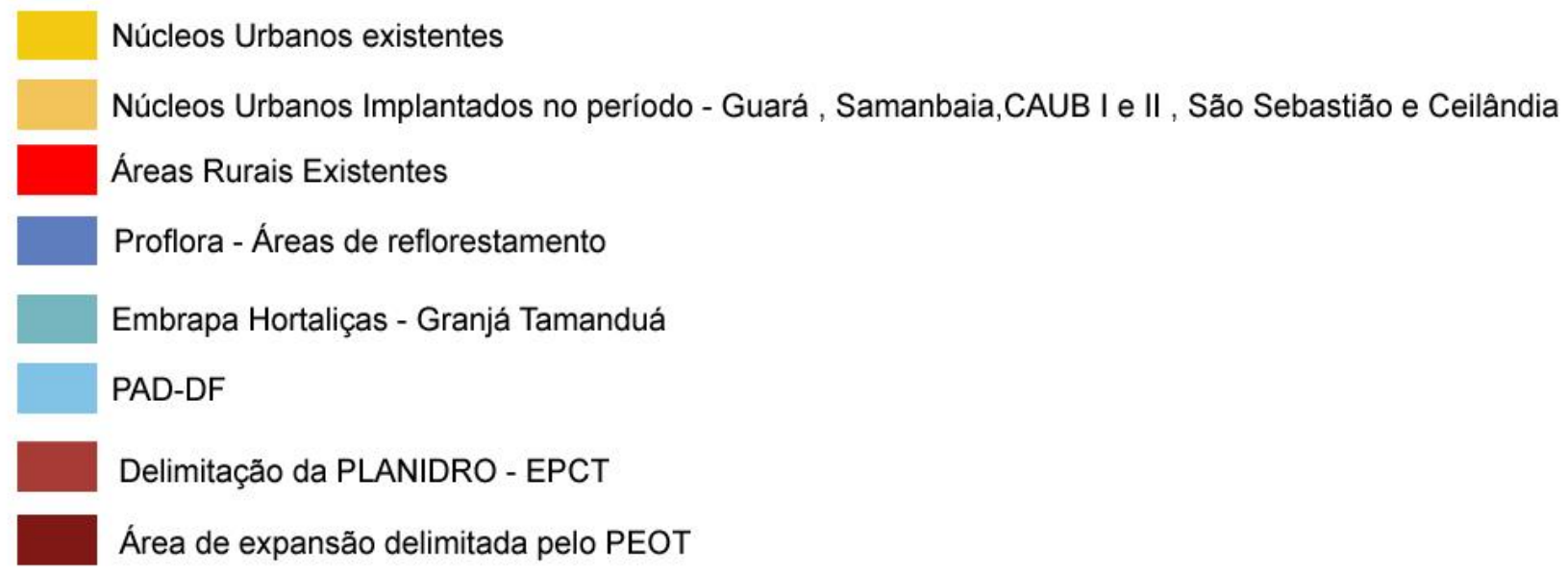

Figura 34: Desenho esquemático com a localização de alguns dos principais elementos do período - décadas de 1970 e 1980 - levantados nas categorias de análise. (Mapa base: SEDHU) 
Quadro 7: Síntese - Décadas de 1970 e 1980

\section{Aspectos Econômicos}

- 1971 - Plano Agropecuário do Distrito Federal;

- 1972 - Empresa Brasileira de Pesquisa Agropecuária (EMBRAPA);

- 1972 - Florestamento e Reflorestamento S/A (PROFLORA);

- Instituto Nacional de Colonização e Reforma Agrária

> (INCRA) - Colônia Agrícola Alexandre Gusmão;

- 1977 - Programa de Assentamento Dirigido do Distrito Federal (PAD-DF) agricultura empresarial, mecanizada, mercado externo;

- 1980/83 - Programa de estradas vicinais;

\section{Aspectos Ambientais}

Déc 1970:

- Desconsideração de fatores ambientais em projetos urbanísticos;

- PLANIDRO - segregador espacial;

Déc 1980:

- APAs - objetivo é compatibilizar a conservação da natureza com o uso de parcela de seus recursos naturais.

- Regulamentação do EIA/RIMA

\section{Aspectos Sociais}

- Erradicação de invasões e crescimento das cidades satélites;

- Expansão urbana sobre o rural no entorno;

- 1983 GEPAFI - Grupo Executivo para assentamento de favelas e invasões;

- 1986 combinado agrourbano;

- 1989 regularizadas: Paranoá, Núcleo Bandeirante, Ceilândia, Guará e Samambaia;

- Classe média condomínios;

\section{Aspectos Espaciais}

- 1974 PERGEB - Programa Especial para a Região Geoeconômica de Brasília.

- 1977 PEOT - Plano Estrutural de Organização Territorial do DF - direcionar as áreas de expansão urbana;

- 1985 POT - Plano de Ocupação Territorial do DF macrozoneamento do território;

- 1986/1990 - POUSO - Plano de Ocupação e Uso do Solo 


\title{
5. ÁREAS RURAIS DO DF AO LONGO DO TEMPO - TENTATIVAS DE ORDENAMENTO
}

Esta etapa abrange as décadas de 1990 e 2000. Ficou assim denominada por abranger enorme expansão urbana sobre áreas rurais e tentativas de ordenamento territorial.

\subsection{Década de 1990}

\section{A. Aspectos Econômicos}

Em 1995 a política de distribuição de lotes na área rural foi suspensa. A principal política para a área rural neste período foi o fortalecimento de microempresas por meio do programa Prove visando atender aos pequenos produtores rurais.

\begin{abstract}
O PROVE -"Programa de Verticalização da Pequena Produção Agrícola" - foi desenhado para promover a pequena produção agrícola, seu processamento e sua comercialização. Inclui diversos tipos de sistemas agrícolas urbanos e periurbanos, como hortas, pomares e a criação de animais. A intervenção é no nível individual e/ou coletivo, focalizando especialmente os grupos de menor renda. O PROVE foi iniciado em 1995. No período 1995-1998, cerca de 500 instalações industriais foram instaladas pelo Brasil. Durante esse período, a renda familiar per capita mensal das pessoas envolvidas no programa aumentou de 25 para 100 dólares. Em média, cada projeto gerou trabalho para seis pessoas, geralmente membros da mesma família. Os recursos desembolsados pelo setor público (US\$200) por cada posto de trabalho gerado pelo PROVE foram destinados estritamente a cobrir os gastos operacionais de recursos já existentes dedicados à capacitação, como, por exemplo, salários, combustível etc., os demais custos de produção correm por conta dos próprios produtores. (Carvalho, J.L.H in: http://www.agriculturaurbana.org.br/RAU/AU05/AU5prove.html
\end{abstract}

Uma das principais críticas a essa política foi seu caráter paternalista. Porém, como era um programa de governo e não uma política de Estado, não houve continuidade após a mudança de governo. 
Também fazia parte desse período, um espaço para comercialização dos produtos dos pequenos produtores criado junto à Sociedade de Abastecimento de Brasília -SAB. Localizava-se na entrequadra 406/407 Sul, no Plano Piloto.

\section{B. Aspectos Ambientais}

A escassez de recursos hídricos, junto com a necessidade de preservação ambiental levou a implantação das APAS e demais unidades de conservação. Porém, houve uma "proliferação de unidades de conservação sem recursos orçamentários e técnicos para efetivá-los como tal" (SILVEIRA, 1999, p.124). A ausência de fiscalização e implantação de planos de manejo corroborou com a degradação ambiental e ocupações irregulares nestas áreas que deveriam estar protegidas.

Em 1996 definiu-se o rezoneamento da APA do São Bartolomeu por intermédio da Lei 9.262 de 12/01/96 - Lei federal que repassa a administração e fiscalização da APA do São Bartolomeu para o DF. Ela veio facilitar o processo de parcelamento urbano dos condomínios.

Devido ao grande número de condomínios irregulares em áreas rurais e de interesse ambiental, fez-se o rezoneamento abrindo a possibilidade de ocupação para fins urbanos. Definiu-se também a realização de monitoramento da área para conter o avanço urbano; o que não ocorreu.

Outro exemplo de desconsideração do sitio local deu-se na implantação da RA de São Sebastião dentro da APA do rio São Bartolomeu. Acarretou a inviabilização da construção da barragem prevista no zoneamento da APA além de agravos ambientais.

Reforçando a necessidade de preservação do bioma cerrado, a lei 742 de 28/07/1994 vem definir os limites, funções e sistema de gestão da Reserva da Biosfera do Cerrado do Distrito Federal (fig.35). “As Reservas da Biosfera fazem parte do Programa "O Homem e a Biosfera" da UNESCO, e têm por objetivo desencadear o planejamento multisetorial, voltado à conservação da diversidade biológica e cultural, ao conhecimento científico e ao desenvolvimento sustentável das regiões nelas 
inscritas." (cap.1, art.1ํ). A delimitação da reserva no Distrito Federa foi a primeira parte na delimitação da reserva da biosfera do cerrado ${ }^{25}$.

A Reserva da Biosfera do Cerrado no Distrito Federal abrange os seguintes espaços geográficos:

I - unidade de conservação do Distrito Federal, onde encontra-se preservado importante acervo biológico representativo do Bioma Cerrado;

II - áreas de relevante interesse para a recuperação da cobertura vegetal;

III - áreas de relevante interesse hídrico, estratégicas para a população do Distrito Federal;

IV - áreas urbanas e rurais, fundamentais para a implantação de programas específicos que gerem conhecimentos e auxiliem na compreensão da dinâmica de ocupação do território e sua relação direta com a sustentabilidade dos recursos naturais disponíveis e necessários.

\section{$\square$ Zonas Núcleo}

ZZonas Tampăo

Zonas de Transiçăo

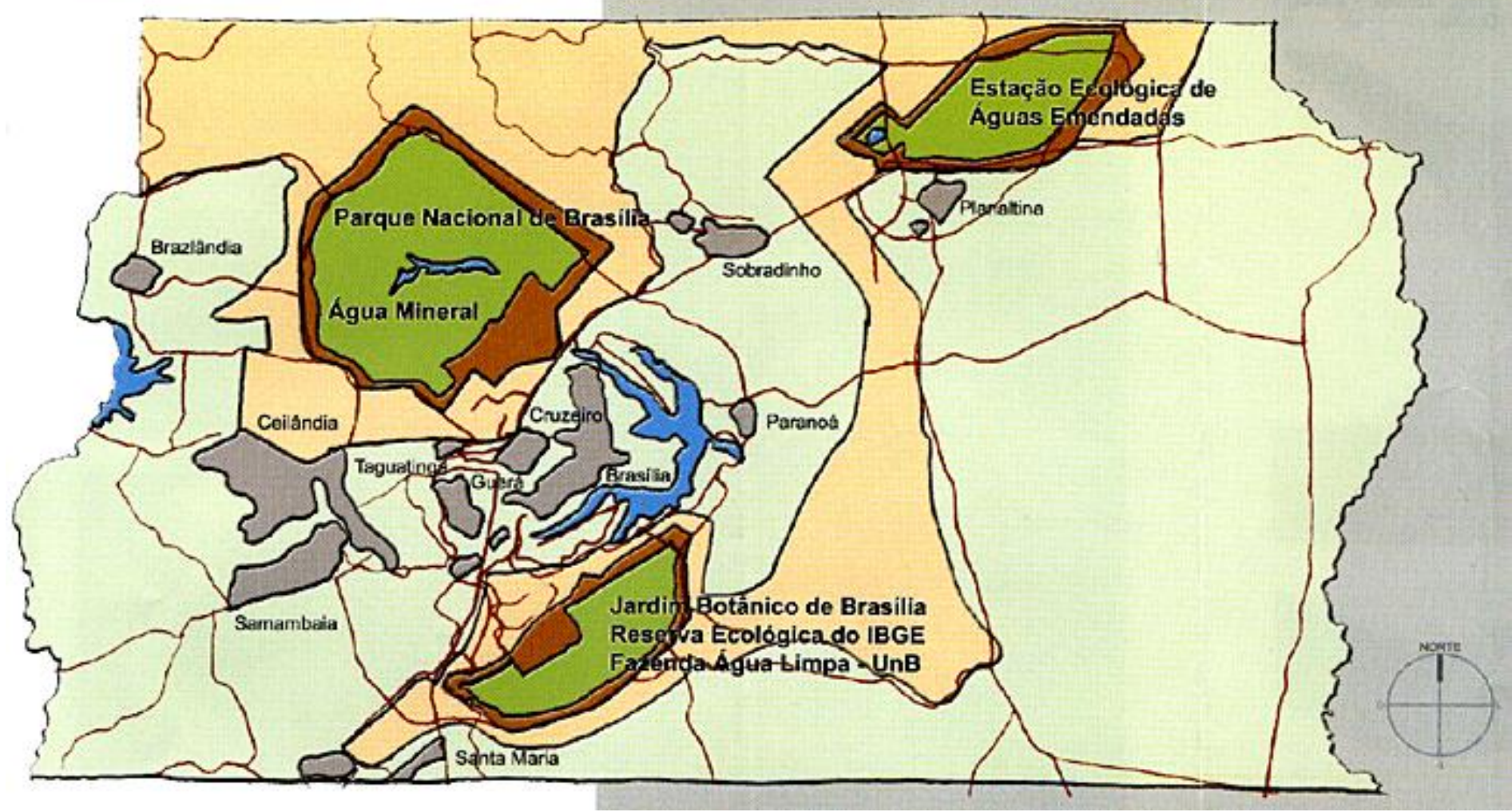

Figura 35: Reserva da Biosfera do Cerrado no DF. fonte:

http://www.rbma.org.br/mab/unesco_03_rb_cerrado.asp

${ }^{25}$ A Fase II foi Goiás em 2000, a Fase III: TO, MA e, PI, em 2001. 
Em seus primeiros anos de existência, a RBCDF permaneceu praticamente inativa. Não foi inserida nas atividades relacionadas às APAs e as áreas núcleos funcionaram de forma isolada, sem qualquer integração entre si. Embora as Reservas da Biosfera se baseiem em uma visão regional de planejamento, o Poder Público, não incluiu ou considerou a RBCDF em suas ações de planejamento.

Ainda nesta década, é importante destacar a criação da Unidade de Conservação Federal Floresta Nacional de Brasília - FLONA. Criada por decreto presidencial, possui uma área de 9.336,14 hectares. Dividida em quatro glebas descontínuas; localizadas nas RAs de Taguatinga e de Brasilândia. A FLONA tem como objetivo o reflorestamento, lazer e sustentabilidade, educação ambiental e proteção do entorno do Parque Nacional de Brasília.

A figura 36 ilustra as glebas destinadas à FLONA. Eram antigas áreas da PROFLORA onde haviam projetos de Reflorestamento. As áreas 1 e 4 estão bem preservadas. Porém as áreas 2 e 3 sofrem processo de invasões e expansão urbana. A área 2 é a mais emblemática. Neste período, o governo do GDF iniciou a implantação de um assentamento rural. Paralelamente, o governo federal definia o local como uma das áreas da Floresta Nacional. A confusão criada acarretou novo processo de invasão da área para expansão urbana. 


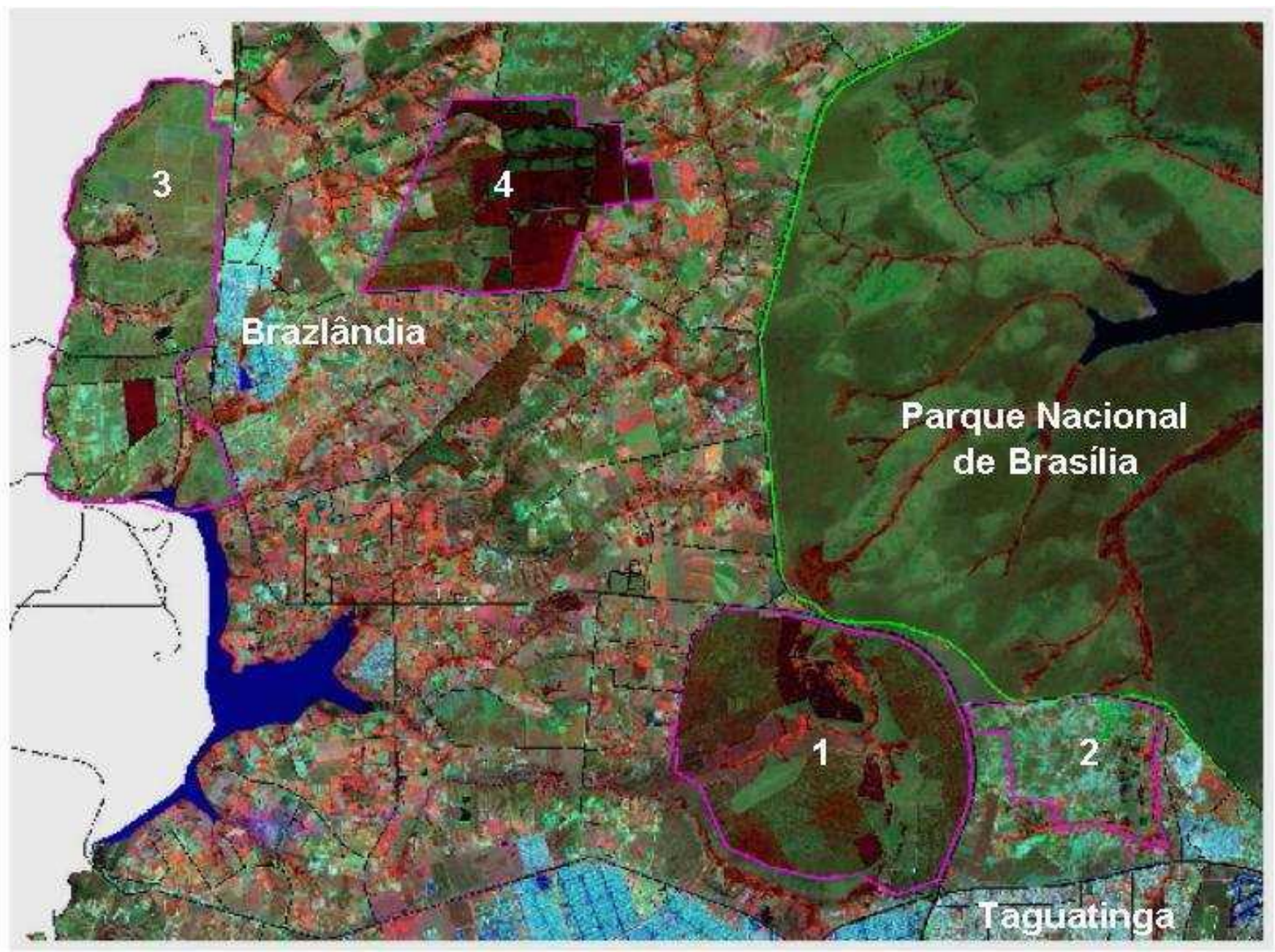

Figura 36: Glebas da Floresta Nacional

\section{Aspectos Sociais}

No final da década de 1980 e meados da década de 1990, implementou-se um programa populista de cunho eleitoral com a apropriação, por parte do gestor público, do controle estatal das terras rurais. Visava atender 100.000 (cem mil) famílias. Era o programa de assentamento de população de baixa renda do DF estabelecido pelo Dec. 11597 de 24/05/89 e decisão 105/89 do CAUMA. Na sequência, a Lei. 216 de 23/11/91 estabelecia critérios para distribuição de casas ou lotes.

Por intermédio da atuação governamental e a pretexto de reduzir a demanda habitacional de baixa renda foram distribuídos lotes semi urbanizados nas áreas rurais. A doação de quase 120 mil lotes não supriu a demanda e serviu para incentivar o avanço de novas invasões.

Conforme aponta Sanzio: 
...a década de 1990 é a fase do esgotamento dos espaços para expansão no Plano Piloto e na maioria das chamadas cidades satélites implementadas. Verifica-se o surgimento de um maior número de invasões habitacionais e uma intensificação nas ações incrementais do Estado, criando assentamentos sem tratar o problema habitacional na dimensão requerida. Com um conjunto urbano de 30.962 ha de extensão, Brasília revela-se com indicadores de uma metrópole jovem, seja pela sua complexidade funcional, seja pelo crescimento demográfico expressivo; (Sanzio, 2012, p.)

Santa Maria, Recanto das Emas e Riacho Fundo são novas cidades que se constituem nesta política. São oficializados nesse período as Regiões Administrativas de: Santa Maria (04/11/1992), São Sebastião (10/05/1994), Recanto das Emas (28/07/1993), Riacho Fundo (15/12/1993) e Candangolândia (27/01/1994). A lei 348 de 04/11/92 e o decreto 14.604 de 10/02/93 tratam da criação da Região Administrativa de Santa Maria, desvinculando-a do Gama.

Sobradinho II, era um exemplo dessa política com a desapropriação de áreas particulares. O Decreto №. 13.362 de 07/08/1991, declarou de utilidade pública, para fins de desapropriação, as glebas de terras de particulares e direitos de arrendamentos de chacareiros das fazendas "Sobradinho" e "Paranoazinho", com a finalidade de dar continuidade ao programa de assentamento da camada da população de baixa renda.

Paranoá e São Sebastião estão entre os novos nucleamentos que se constituem através da fixação de invasões. Em 1991 houve a fixação da Agrovila de São Sebastião. As glebas que eram de utilização rural foram reparceladas. Em 1993 institucionalizouse com a criação da Região Administrativa de São Sebastião (RAXIV) desvinculando-a do Paranoá.

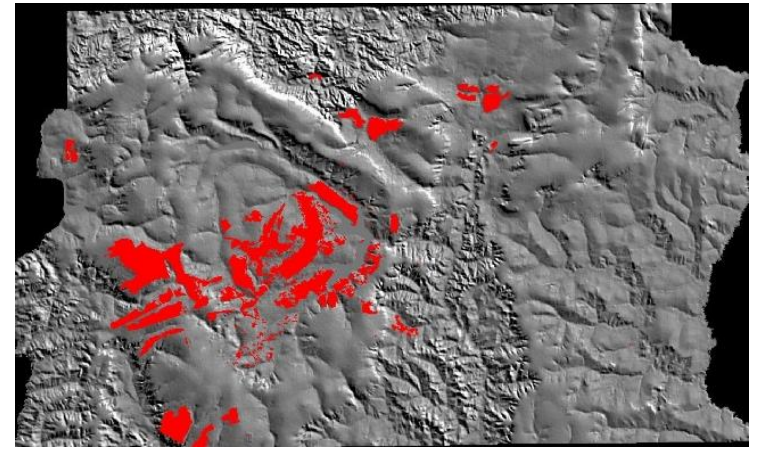

a)

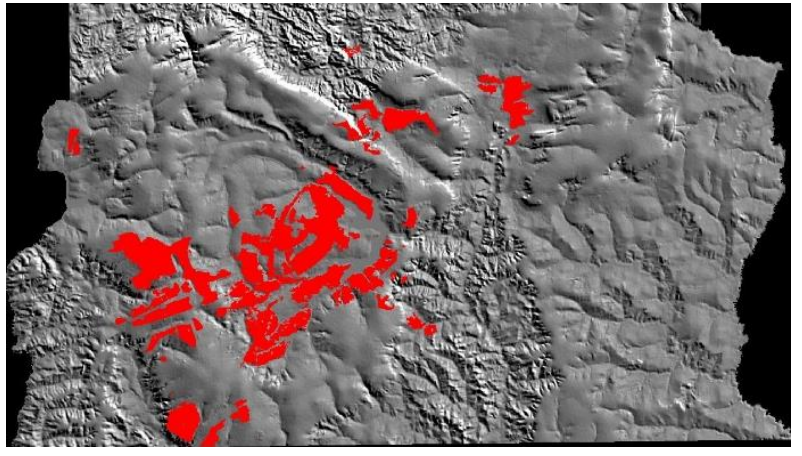

b)

Figura 37: Ocupação urbana em 1994 e 1998. (Fonte: SEDUH) 
No âmbito da moradia rural, apenas a Lei 1572 de 22/07/97 cria o programa de assentamento de trabalhadores rurais PRAT, de interesse social, para atender os trabalhadores rurais na questão da moradia.

\section{Aspectos Espaciais}

Com a implantação da Câmara Legislativa do Distrito Federal, a mesma também passa a atuar em questões relativas a uso e ocupação do solo; o que pode ser observado através das leis de implantação de agrovilas e regularização de áreas. Esta sobreposição acarretou em alguns casos Ação Direta de Inconstitucionalidade.

Conforme estudo do IPEA, a atuação da Câmara alterou significativamente as ações referentes ao uso do solo no Distrito Federal, uma vez que ela passou a legislar sobre a questão territorial concomitantemente ao Executivo e, na maior parte das vezes, de forma totalmente desarticulada. (IPEA, 2002, p.53)

Algumas Leis de Iniciativa da Câmara Legislativa do DF relativas às áreas rurais:

- Lei 1273 de $29 / 11 / 96$ autoriza o poder executivo a implementar agrovilas (7) nas áreas rurais do DF.

- 1997: Lei 1480 de 17/06/97 Dispõe sobre a instituição da Colônia Agrícola do Catetinho em áreas dos CAUB I, II e III.

- 1997: Lei 1659 de 15/09/97 Criar e implantar a Agrovila da Chapada da Contagem em Sobradinho.

- 1997: Lei 1698 de 24/09/97 Cria o núcleo Rural São Sebastião nesta RA.

- 1997: Lei 1781 de 25/11/97 Regularização e titulação dos lotes e agrovilas I e II do Combinado Agrourbano de Brasília (CAUB I e II).

Em 1995, o Governo do Distrito Federal constituiu o Grupo Executivo de Trabalho para Parcelamentos Irregulares - GET/PI. Levantamento feito pelo GET/PI revelou a existência de 529 condomínios irregulares. Dos 232 que apresentavam condições para regularização, 212 estavam em áreas públicas da TERRACAP. 
Além do grupo de trabalho, diversas leis foram elaboradas para trabalhar a questão dos parcelamentos irregulares. Lei 759/94: alienação de terras públicas, urbanas e rurais nas áreas de expansão urbana. Complementada e revogada pela Lei 954/95. Lei 801 de 29/11/94: Novo prazo para apresentação de projeto urbanístico de loteamento. Dec.16290 de 23/01/95: Estabelece medidas emergenciais para coibir a ocupação de terras públicas no DF. Dec. 7261 de 01/04/96: Possibilita a regularização de grupos de parcelamentos por bairros.

No conjunto destes parcelamentos: $54,36 \%$ eram fazendas totalmente desapropriadas; 33,28\% pertencentes a particulares; 8,53\% fazendas desapropriadas em comum (imóveis desapropriados sem definição dos limites da propriedade pública e da particular); e 6,83\% estavam com o processo judicial de desapropriação ainda em tramitação (CODEPLAN/GDF, 1997). A figura 36 ilustra a situação fundiária do DF em 1995.

Em 1998, com a publicação da Lei $n .0$ 1.823/98, foram aprovadas as poligonais de estudo dos Setores Habitacionais: Jardim Botânico, São Bartolomeu, Dom Bosco, Taquari e Boa Vista. E, por emenda da Câmara Legislativa, foi acrescentado o Vicente Pires. 

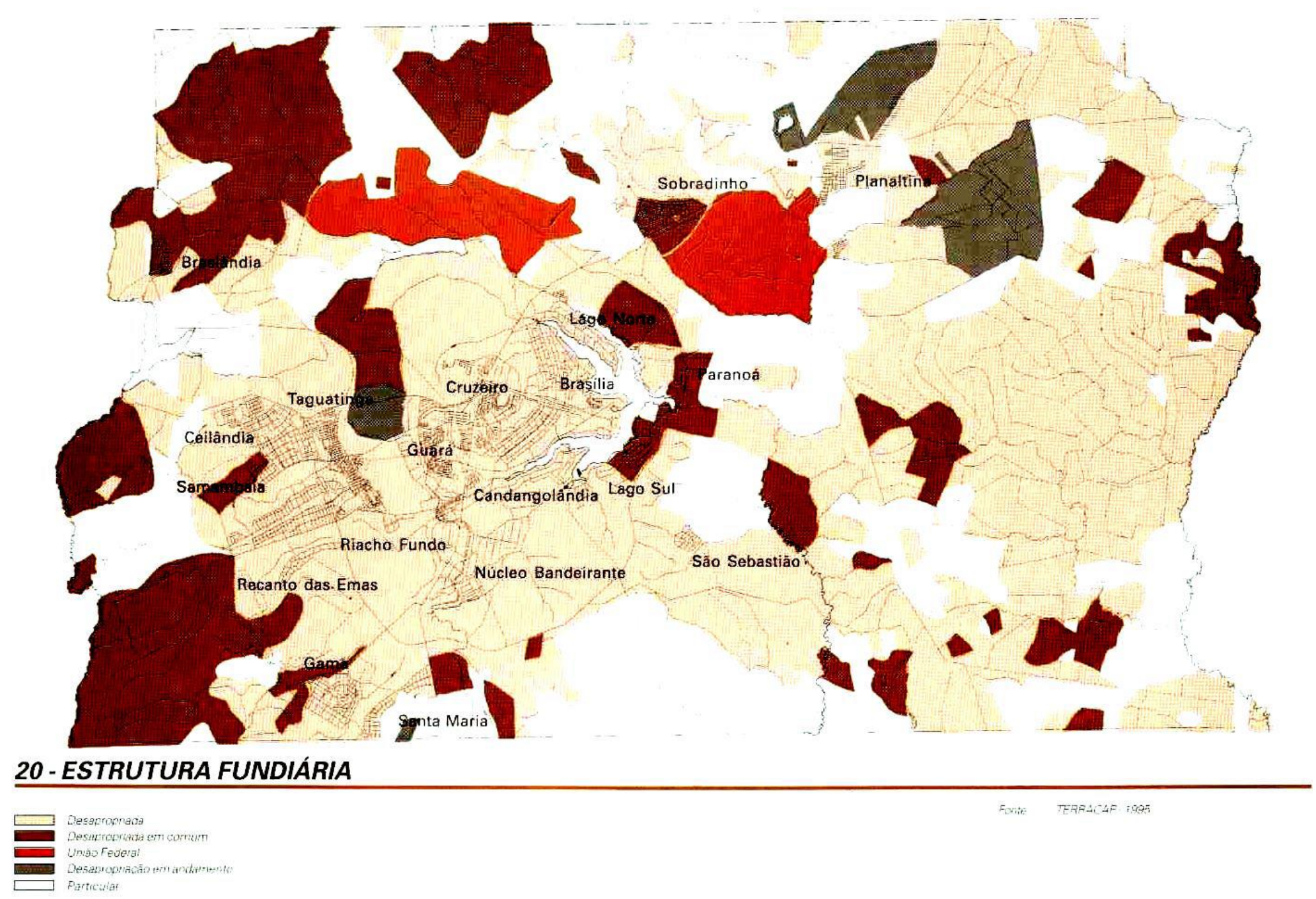

Figura 38: Situação fundiária do DF de 1995. (Fonte: Silva, 2011, p.31 apud Arquivos fundiários da SPU-DF, 2004). 


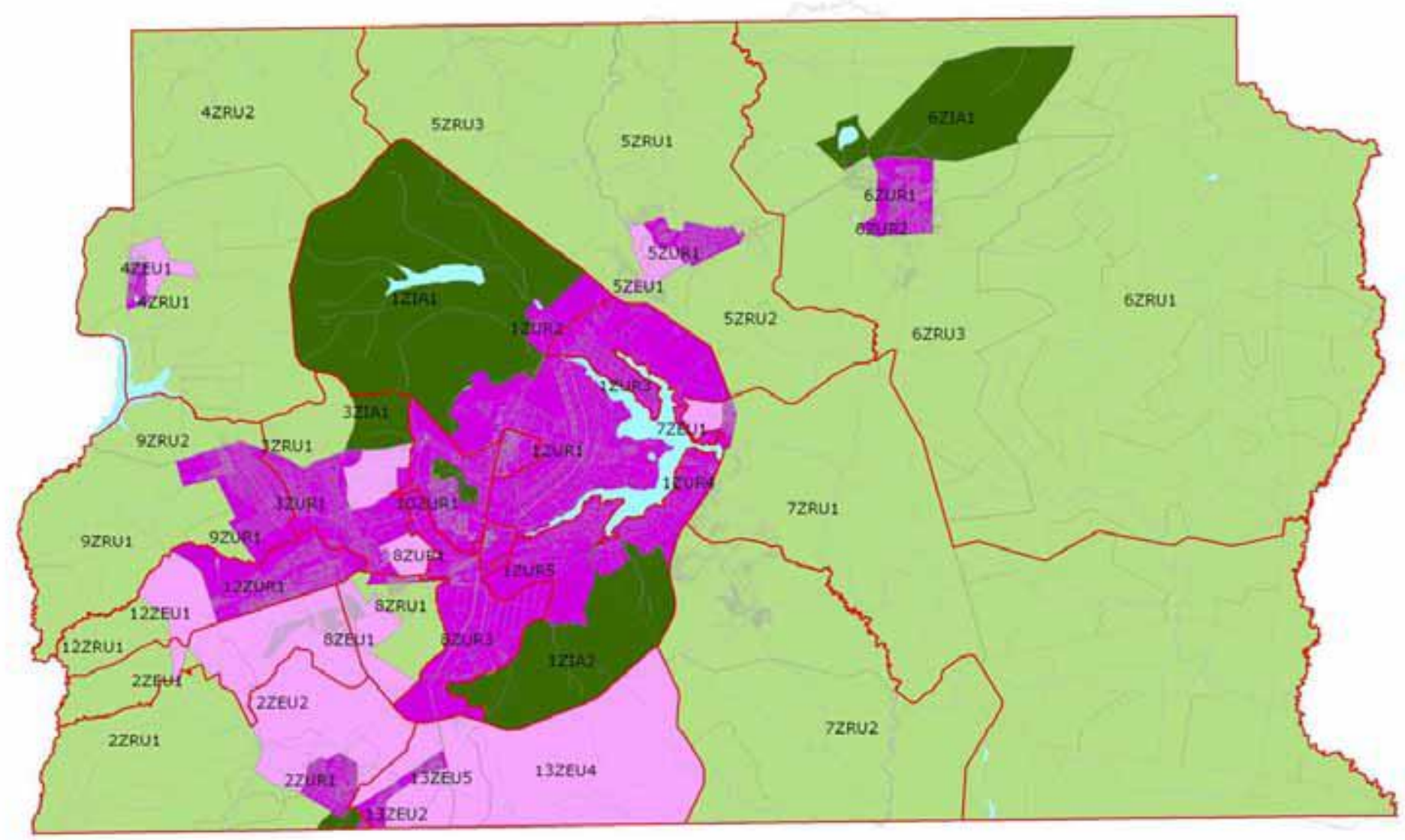

(ands

ZEU - ZONA DE EXPANSÁO URBANA

ZUR - ZONA RURAL

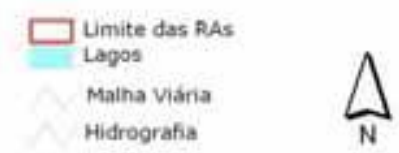

$\Lambda_{N}$

Macrozoneamento do PDOT/92

Lei $n .0^{\circ} 353 / 92$

Figura 39: Plano Diretor de Ordenamento Territorial - PDOT/92. (Fonte:Mancini apud SEDUMA) 
Em 1992 o Distrito Federal realiza seu primeiro Plano Diretor de Ordenamento Territorial (Lei 353 de 18/11/1992), fig.39. Visava consolidar os diversos planos existentes. Definiu o macrozoneamento do território criando as seguintes categorias de uso do solo: urbana, expansão urbana, interesse ambiental e rural. Inovação apresentada no PDOT/92 é a possibilidade de o particular parcelar o solo.

As Zonas Rurais (ZRU) eram aquelas destinadas, predominantemente, às atividades agrícolas, pecuária, agroindustrial ou de usos complementares e compatíveis com estas.

No intervalo de cinco anos, elaborou-se novo PDOT (Lei Complementar n.은 17/1997) com flexibilização de usos, diversidade e zoneamento menos rígido. Estipulava três categorias de zonas: urbana, rural e de conservação ambiental. As zonas rurais subdividiam-se em:

- Zona Rural de Dinamização (áreas de atividades agropecuárias consolidadas),

- Zonas Rurais de Uso Controlado (I, II, III, com restrição do uso do solo em razão da preservação de mananciais e de seu grau de sensibilidade ambiental.) e,

- Zona Rural de Uso Diversificado (permitido, além do uso agropecuário, a instalação de atividades agroindustriais e de lazer).

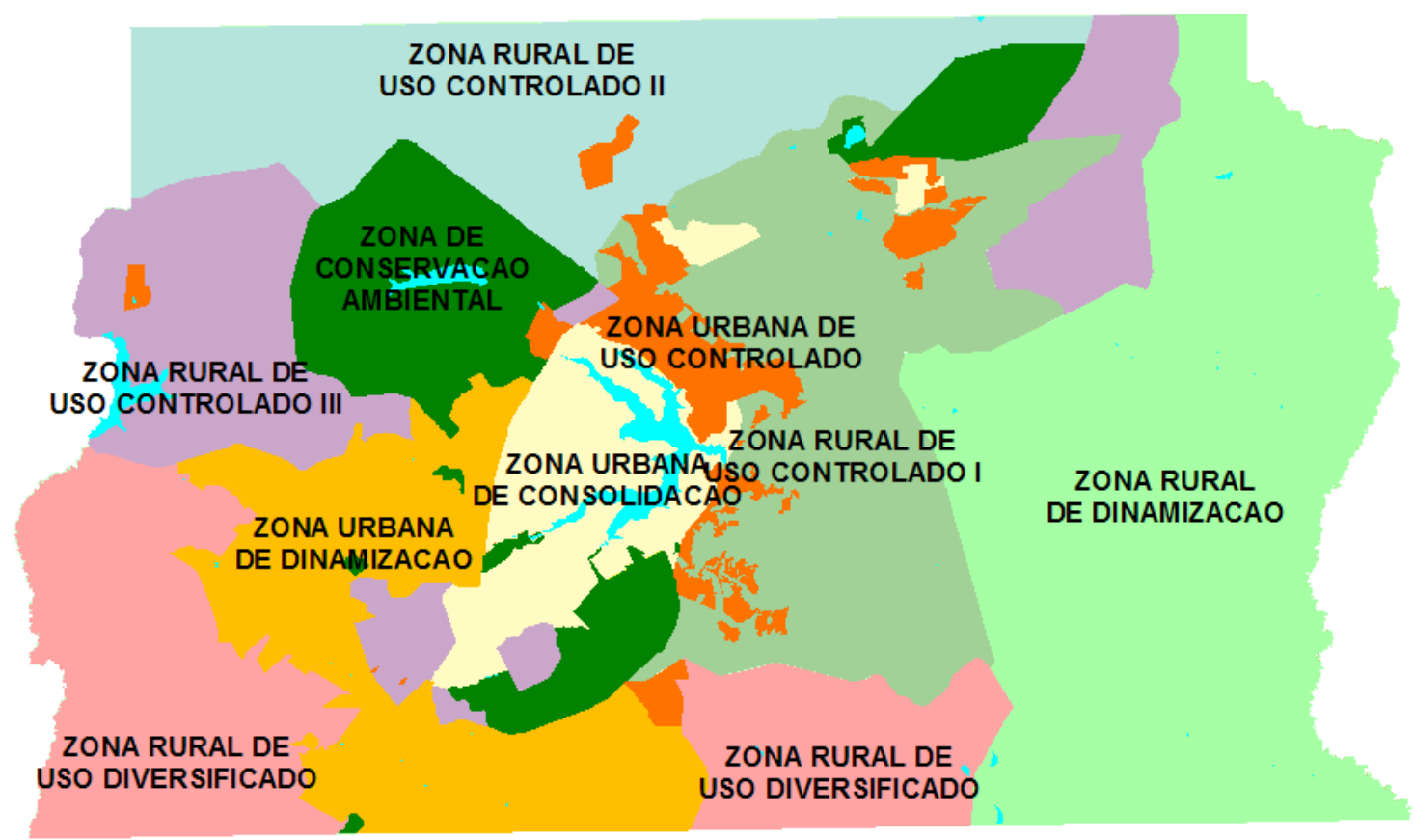

Figura 40: PDOT/1997: Macrozoneamento. Fonte:ZEE,2009 
Além do macrozoneamento, também estabeleceu-se um conjunto de cinco subzonas territoriais, definindo parâmetros de diretrizes de uso e de ocupação diferenciadas. Relativo às áreas rurais estão: Áreas Especial de Proteção (Áreas de Proteção de Manancial e Áreas Rurais Remanescentes); Áreas com Restrições FísicoAmbientais; Áreas de Lazer Ecológico; Áreas de Monitoramento Prioritário (devido à incidência de parcelamentos irregulares).

Ao fazer uma atualização do macrozoneamento, o PDOT de 1997, reconhece as áreas produtivas rurais em enclaves urbanos denominando-as de áreas rurais remanescentes e, as áreas dos parcelamentos urbanos irregulares que passaram a ser chamados de zona urbana de uso controlado. Na APA do São Bartolomeu definiu nova zona urbana na área de incidência dos parcelamentos irregulares propiciando sua regularização.

\subsection{Década de 2000}

\section{A. Aspectos Econômicos}

A lei 2.499, de dezembro de 1999, institui o Plano de Desenvolvimento Rural do Distrito Federal - PRÓ-RURAL/DF-RIDE:

[...] tem por objetivo criar uma nova base de sustentação da agropecuária da região para, através da diversificação e da agregação de valor à matériaprima, utilizar o potencial do mercado de Brasília promovendo a geração de empregos e renda no meio rural. (art 30 da lei 2499/1999)

Com um programa amplo envolvia os seguintes segmentos: pecuária de leite e de corte; ovinocultura; fruticultura irrigada; piscicultura; floricultura; agroindústria rural; agricultura orgânica; sanidade animal total; irrigação localizada; recuperação e manejo de microbacias hidrográficas; turismo rural; horticultura; apicultura; avicultura de postura; suinocultura e bubalinocultura. 
No ramo de hortaliças, a produção bateu recordes neste período. Conforme dados da EMATER-DF, foram produzidos mais de 207 mil toneladas em 2009, estando o DF com a maior produtividade média de hortaliças no Brasil. Um dos fatores para o sucesso do setor é a adoção de tecnologia pelos produtores - parceria entre EMATERDF e Embrapa Hortaliças (Brasília-DF). A adaptação e o desenvolvimento de tecnologias nas áreas de manejo da fertilidade do solo e de nutrição de plantas estão entre as principais contribuições da pesquisa agropecuária para os produtores do DF.

A figura 41, (EMATER, 2009), apresentam a distribuição espacial no território do DF das hortaliças e grandes culturas. Observa-se a predominância de Braslândia na produção de hortaliças e a vocação agrícola no leste do território. 

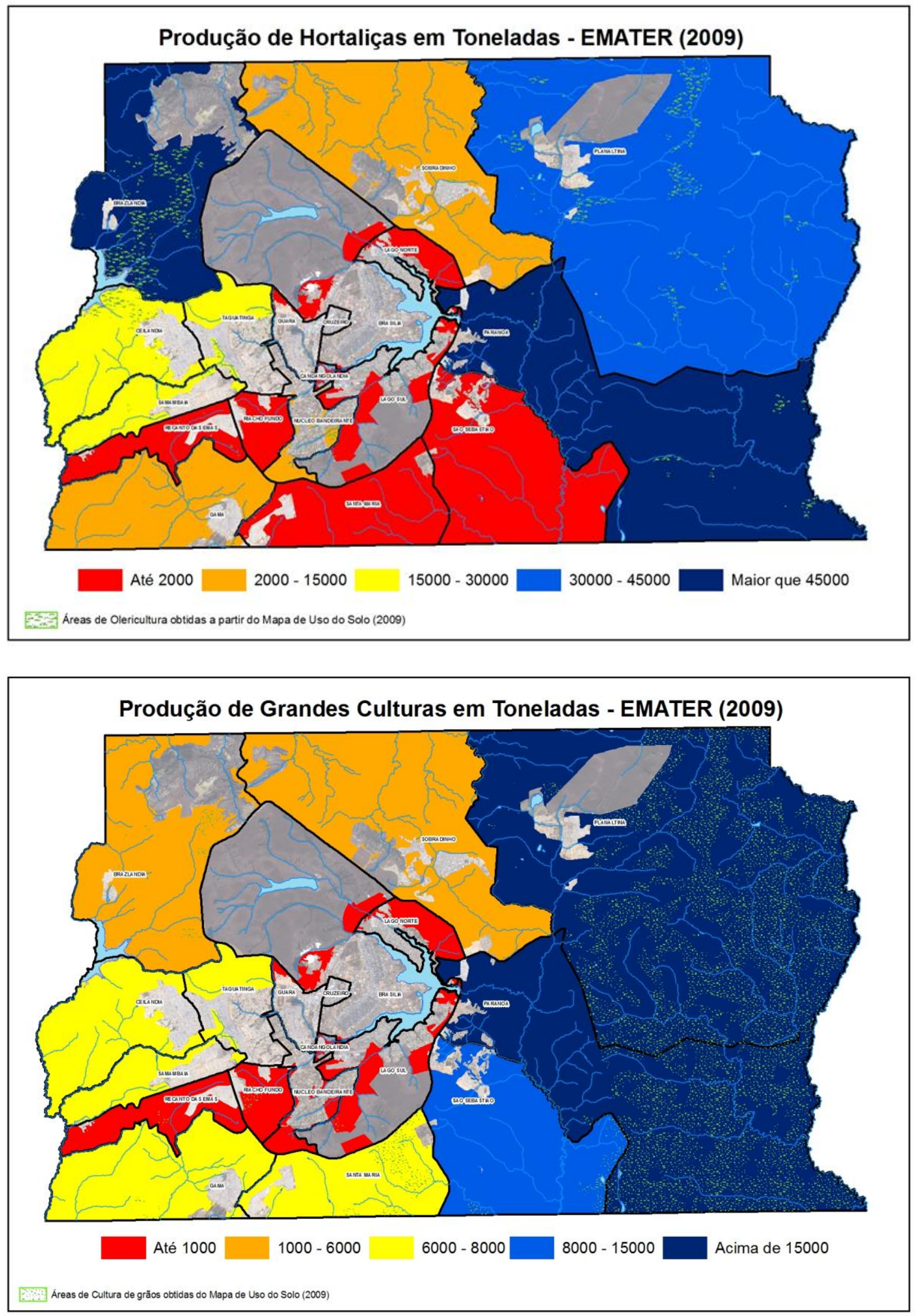

Figura 41: Produção de hortaliças e grandes culturas - EMATER 2009

(fonte:ttp://www.cnph.embrapa.br/paginas/imprensa/releases/recorde_producao_hortalica_df.html) 
Outro indício do avanço da produtividade no meio rural são os Pivôs de irrigação, fig. 42, observados principalmente nas áreas rurais do Paranoá e Planaltina onde se encontram grandes culturas. Há uma forte concentração na Bacia do Rio Preto.

O aumento da demanda de água para a irrigação tem sido objeto de constante preocupação dos órgãos de gestão dos recursos hídricos e da população do Distrito Federal, uma vez que essa unidade federativa apresenta baixo índice de disponibilidade hídrica por habitante por ano. (Sano, 2005, p.514)

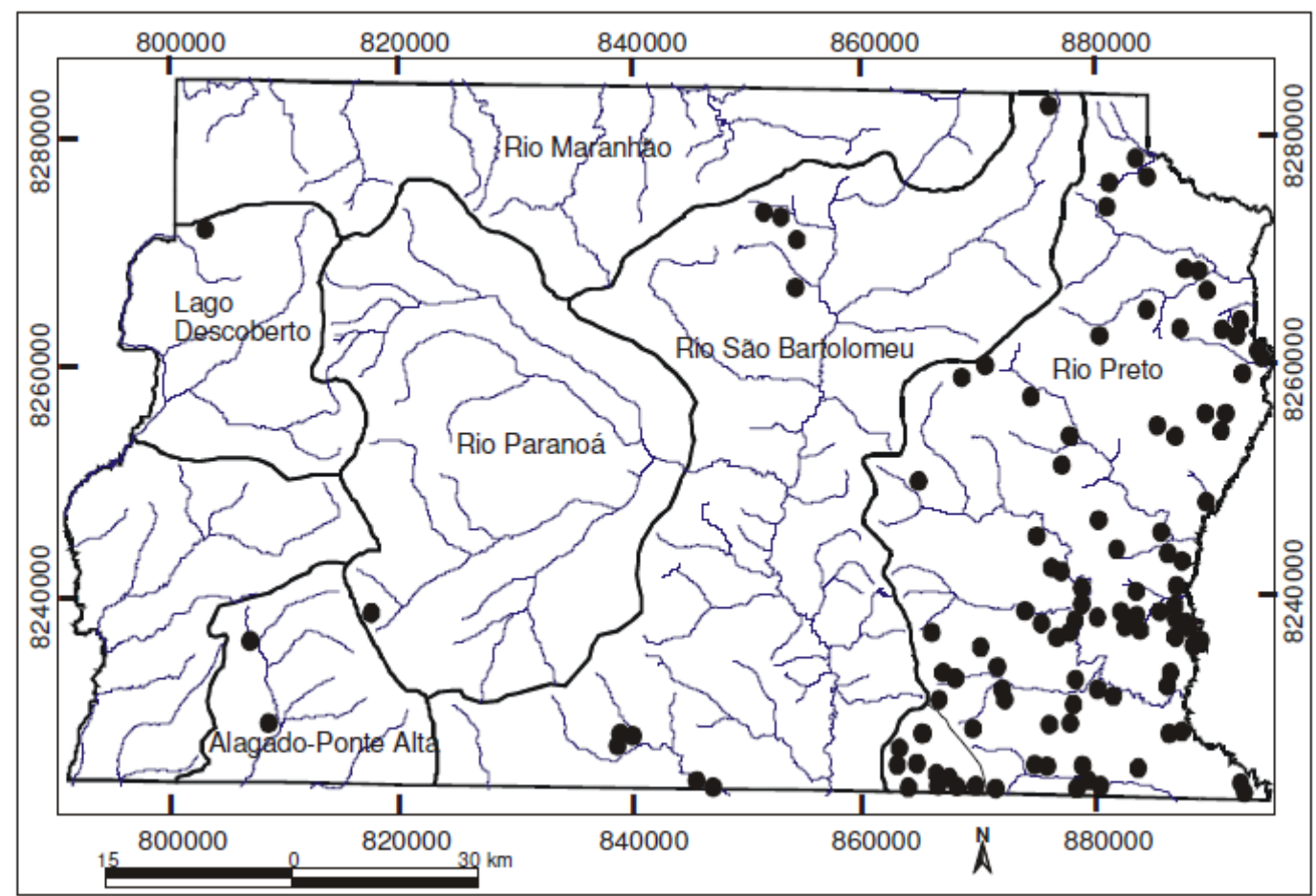

(h)

Figura 42: Pivôs-centrais instalados no Distrito Federal em 2002. Fonte: SANO, et all, 2005.

Os maiores diferenciais que se observam nesse período é um aprimoramento nos programas produtivos. Independente do segmento agrícola, a agricultura praticada no Distrito Federal passa a se caracterizar por alta produtividade e incremento tecnológico. 


\section{B. Aspectos Ambientais}

O gráfico denominado: 'indicadores da paisagem' do Distrito Federal, fig.43, ilustra as variações nas paisagens, da implantação da capital até o início da década. Indica o aumento de atividades agrícolas e a diminuição de biomas e pastagens naturais.

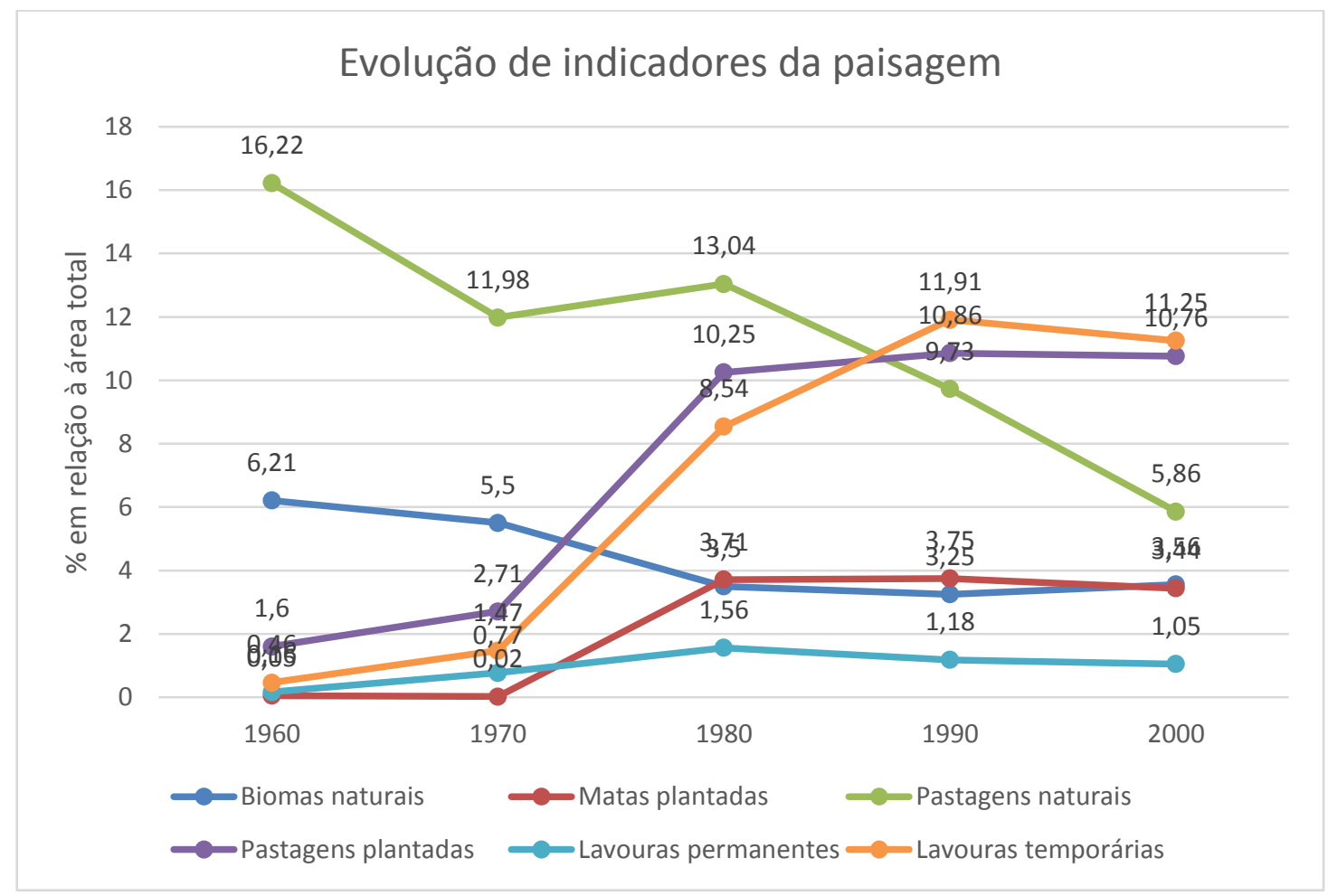

Figura 43: Evolução das proporções (\%), em relação à área total, das áreas matas plantadas, pastagens naturais, pastagens plantadas, lavouras permanentes e lavouras temporárias no DF entre os anos 1960 e 2000 . Fonte: $O$ CENTRO-OESTE BRASILEIRO COMO FRONTEIRA AGRÍCOLA, baseado em dados do IPEA 2005.

É importante fazer um paralelo entre as variações e as políticas implementadas ao longo das décadas:

As políticas de incentivo à produção implementadas na década de 1970 impulsionaram o aumento das lavouras e pastagens plantadas.

$\checkmark$ As matas plantadas no gráfico indicam a criação e o término da PROFORA (quando mantem certa estabilidade).

$\checkmark$ As áreas de Biomas naturais vinham diminuindo até a década de 1980, quando da implantação das APAS. Sua relativa estabilidade nos períodos seguintes pode estar relacionada à repercussão do 
gerenciamento das APAS (embora ainda de modo incipiente) no tocante à preservação desses biomas.

Além da diminuição das paisagens naturais, outra questão importante é a quantidade de terras adequadas à agricultura. O PDOT/2009 contabilizou as áreas rurais em 397 mil hectares (68\% de toda a área) distribuídas em Zonas Rurais de Uso Diversificado e de Uso Controlado. Nas análises do ZEE sobre a aptidão agrícola das terras rurais do DF (a partir de características dos solos, fertilidade natural, susceptibilidade à erosão e impedimento à mecanização), têm-se 229 mil hectares com condições adequadas para práticas agrícolas. Os demais 162 mil hectares estão situados em áreas com menor aptidão para práticas agrícolas. (ZEE,2009)

INTENSIDADE DE OCUPAÇÃO RURAL X SENSIBILIDADE AMBIENTAL

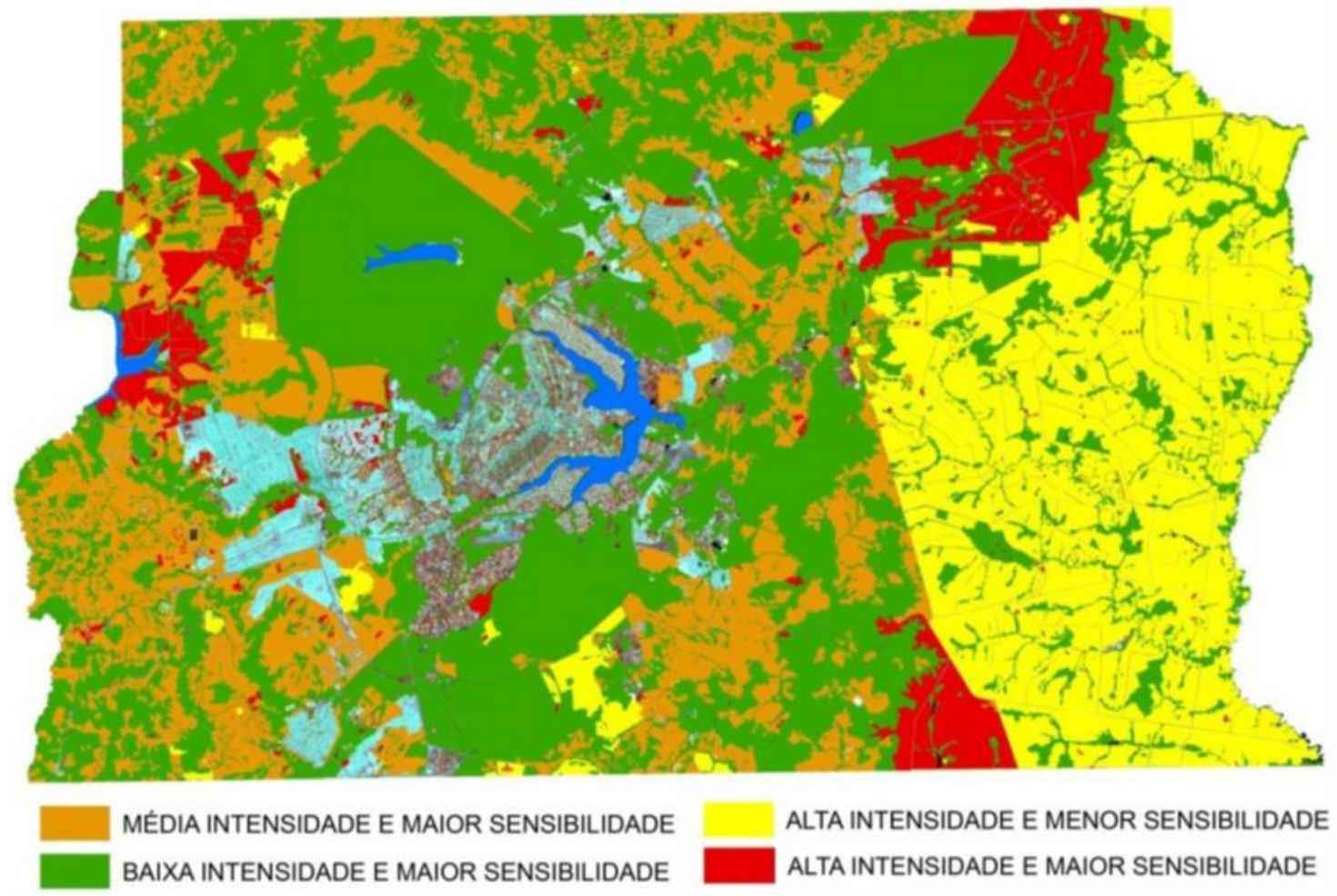

Figura 44: Resultado da interação entre a sensibilidade ambiental do território, com relação aos riscos de perda de solos, de recarga de aquíferos e de biodiversidade, e a intensidade de ocupação das áreas rurais dada pelo tipo de uso do solo. (Fonte: ZEE DF a partir de mapa de uso do solo de 2009)

\section{Aspectos Sociais}

Ao longo das décadas, o Distrito Federal foi gradativamente deixando de ter um padrão polinucleado de ocupação urbana e reforçando a ocupação ao longo dos 
grandes eixos viários/corredores de transporte, intensificando um processo de conurbação urbana.

Hoje, a expansão urbana do DF, vem ocorrendo, principalmente, ao longo de dois vetores: Vetor Sul: SIA, SCIA, área do ParkShopping, Candangolândia, Núcleo Bandeirante, Park Way, Catetinho, Sta. Maria até o Entorno Sul, em Goiás. Vetor Oeste: SIA, Guará, Aguas Claras, Vicente Pires, Taguatinga, Samambaia, Ceilândia até o Entorno Oeste, em Goiás. Um terceiro vetor: o Vetor Nordeste - tende a se fortalecer: Grande Colorado, futura Cidade Digital, Sobradinho, Sobradinho II. (ZEE,2009)

Legitimando essa tendência, são oficializados nesse período as Regiões Administrativas de: Águas Claras, Riacho Fundo II, Varjão, ParkWay (2003); SCIA (Estrutural), Sobradinho II, Jardim Botânico (2004), Itapoã e SIA (2005) e, Vicente Pires (2009). A figura 45 ilustra esse processo.

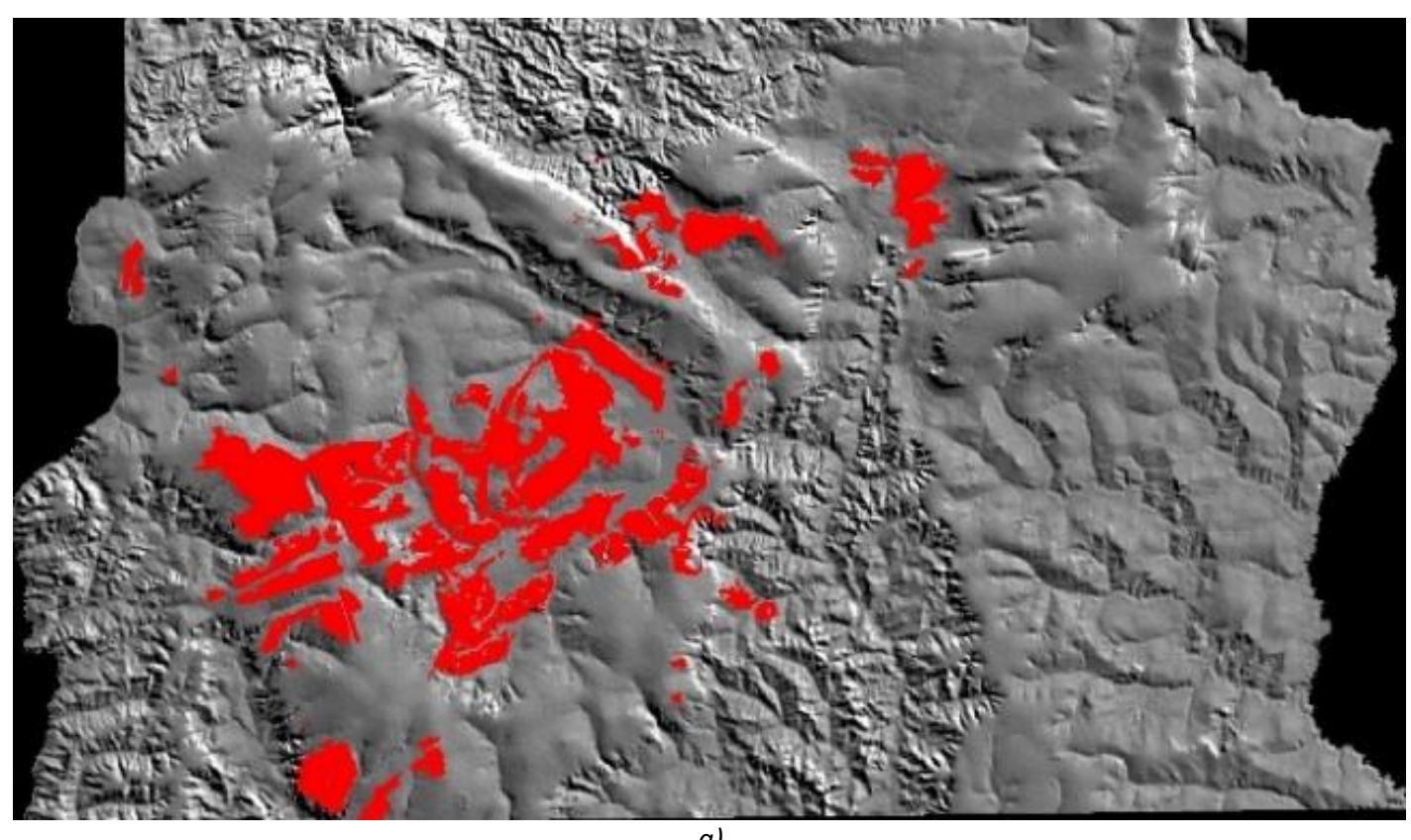




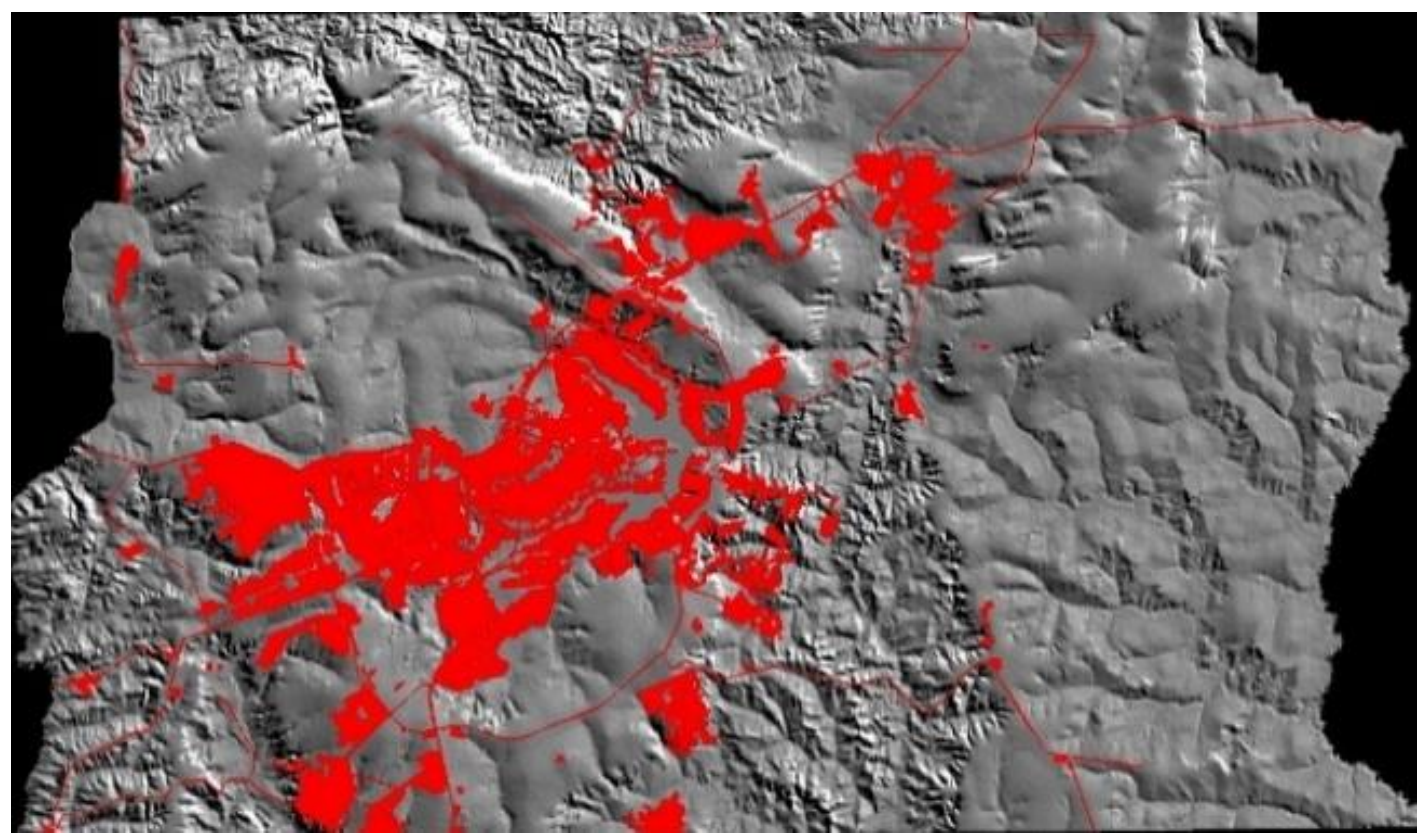

b)

Figura 45: Ocupação urbana em 2001 e 2006. (Fonte: SEDUH)

O avanço das áreas urbanas sobre as áreas rurais até a década de 2000

extrapolou os limites do quadrilátero do Distrito Federal em direção às cidades do entorno de Brasília. Parcelamentos privados de áreas rurais, sem infraestrutura foram empregados para atender as demandas por moradia das populações de baixa renda. Atualmente Brasília conforma uma rede urbana metropolitana com municípios próximos, dos estados de Goiás e Minas Gerais:

“[..] a complexidade de suas funções torna Brasília uma metrópole, que se espraia pelo território de forma não contígua, polinucleada e socialmente desigual, formando assim sua região metropolitana: um todo complexo, heterogêneo e interligado." (FERREIRA, 2010, p.50).

\section{Aspectos Espaciais}

A revisão do PDOT 2007-2009 (LC 803/2009) - figura46, foi uma versão polêmica do PDOT com vários itens declarados inconstitucionais. 


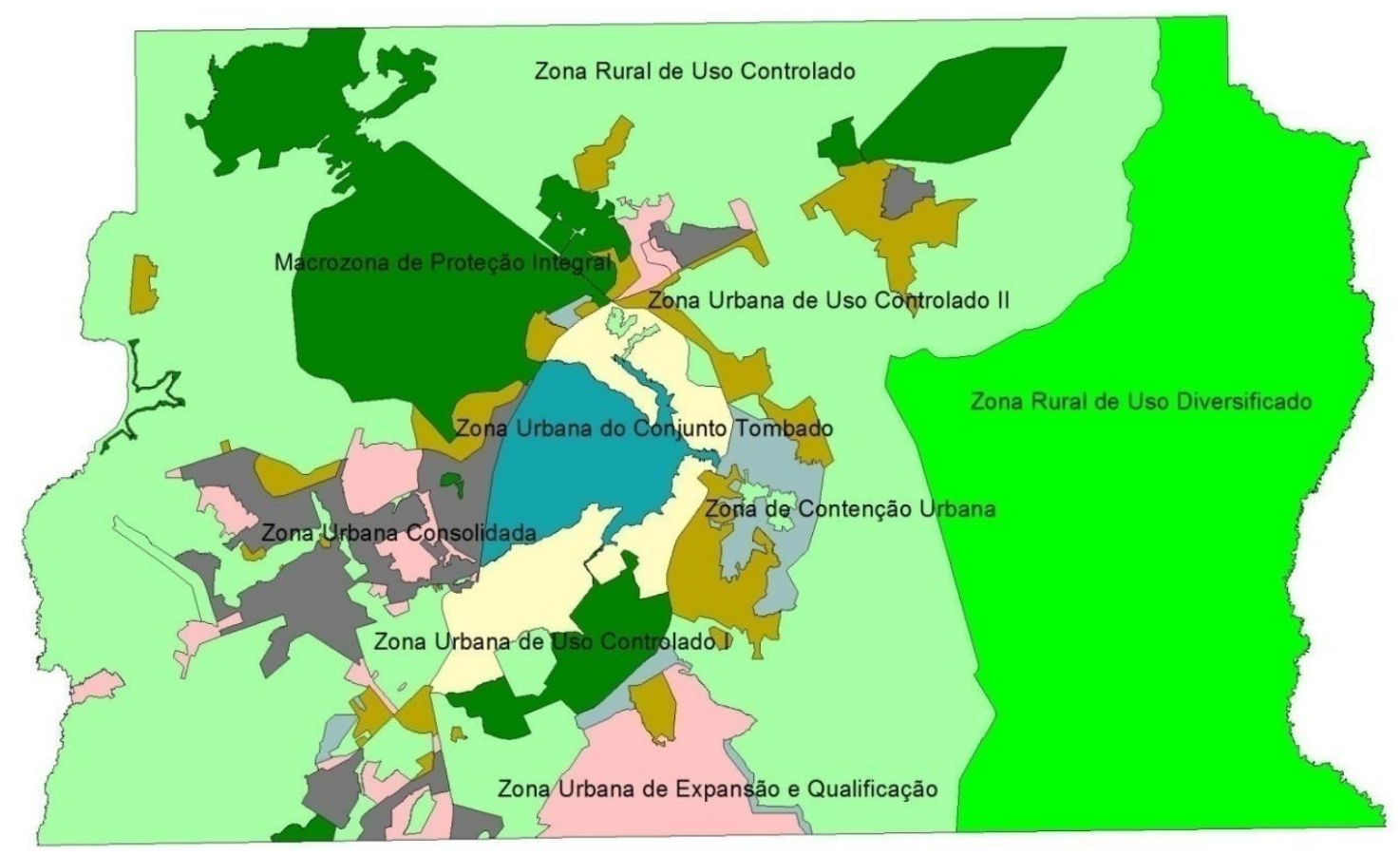

Figura 46: PDOT/2009: Macrozoneamento. (Fonte: SEDUMA - 2009)

Em relação ao zoneamento das áreas rurais, ele extingue a Zona Rural de Dinamização e a transforma em Zona Rural de Uso Diversificado, as demais áreas rurais passam a ser Zona Rural de Uso Controlado. A alteração que aparece destacada é a transformação da área de Zona rural de uso diversificado em Zona urbana de expansão e qualificação.

No documento técnico do PDOT-2009 há uma caracterização da situação fundiária do DF, compreendendo terras de naturezas jurídicas diversas:

- Terras Devolutas - Terras cuja propriedade é desconhecida, não abrangidas por domínio particular por qualquer título legítimo e que não foram objeto de ação discriminatória;

- Terras Públicas - agregadas ao patrimônio público por desapropriação ou doação; entre as terras públicas, há terras de propriedade da Agência de Desenvolvimento do Distrito Federal (TERRACAP), de propriedade da União Federal e de propriedade do Distrito Federal. Terras Particulares - registradas em Cartório de Registro de Imóveis do DF em nome de particulares;

- Terras Públicas e Particulares em Regime de Propriedade Comum adquiridas pela TERRACAP - consideradas terras nas quais o Poder Público desapropriou determinado percentual da gleba, sem definir claramente os limites da propriedade pública ou privada. 


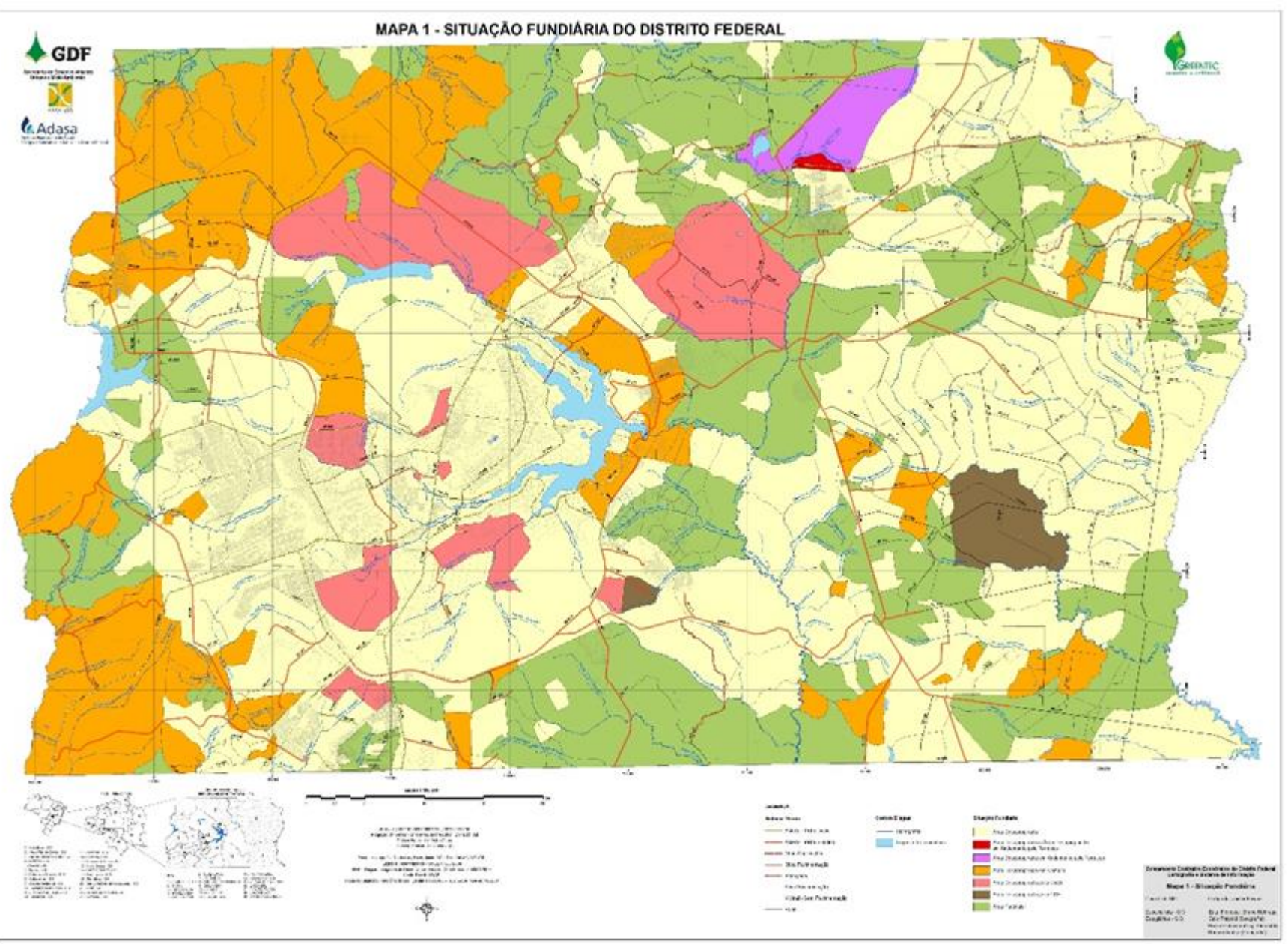

Figura 47: Situação fundiária 2009. (Fonte ZEE, 2010) 
A complexidade dos processos judiciais e a insuficiência de recursos geraram um quadro de indefinição da propriedade da terra - figura 47. Apenas 51\% das terras foram integralmente desapropriadas. Cerca de 31\% ainda são de particulares e aproximadamente $16 \%$ foram desapropriadas parcialmente ou estão em processo de desapropriação. (IPEA, 2002, p.72).

Em 2006, a Subsecretaria de Análise de Parcelamentos Urbanos - SUPAR, elaborou estudo denominado "Diagnóstico Preliminar dos Parcelamentos Urbanos Informais no Distrito Federal", que subsidiou a construção da "Estratégia de Regularização Fundiária", constante da revisão do PDOT/2009. O levantamento revelou a existência de 513 parcelamentos irregulares, dos quais 379 constituídos em zona urbana e 134 na zona rural.

Segundo dados do ZEE, no período 2001-2006 há um salto, de 48,7\% na ocupação urbana devido à criação de cidades satélites; proliferação de loteamentos irregulares; e à conversão, regular e irregular, de áreas rurais em áreas urbanas, sendo Vicente Pires o exemplo mais marcante.

\subsection{Síntese do período}

Os Gráficos da figura 48, com a porcentagem de uso do solo e vegetação característicos do período, expressam os aumentos das áreas urbanas e agrícolas em detrimento das áreas de vegetação natural. O cerrado é o principal prejudicado no uso antrópico do solo.

O aumento das áreas urbanas deve-se à criação de Regiões Administrativas, proliferação de assentamentos irregulares e a conversão de áreas rurais em urbanas nos Planos Diretores. 


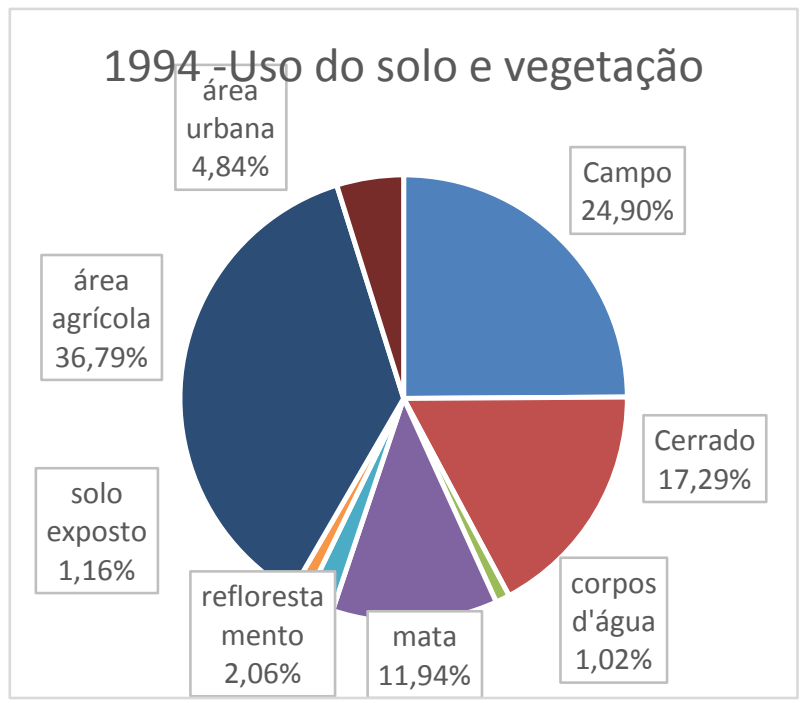

a)

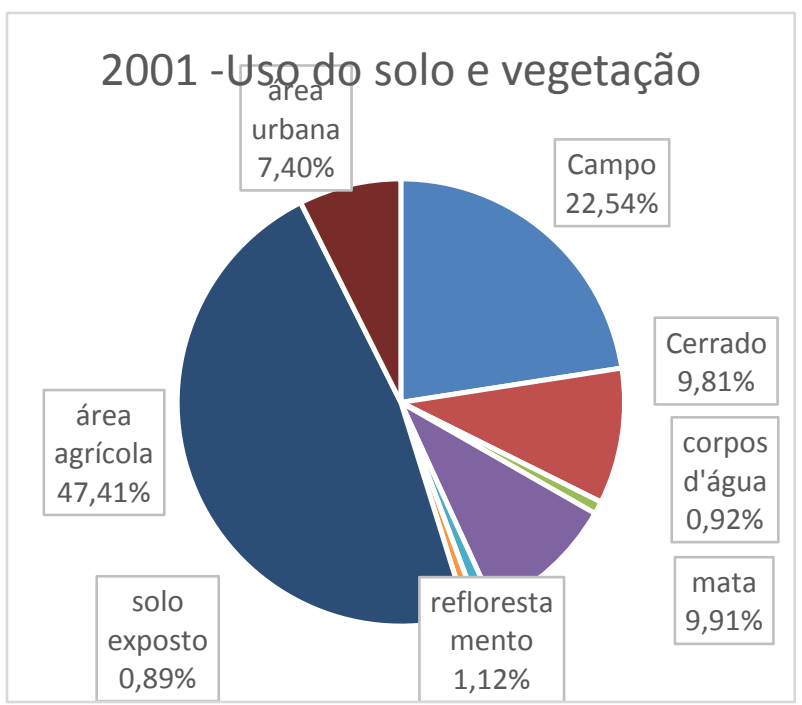

b)

Figura 48: Gráficos de uso do Solo elaborados à partir de material da UNESCO sobre uso do solo e vegetação no DF (2002)

Em relação à produção agrícola, na década de 1990 a inovação foi o fortalecimento de micro empresas para atender pequenos produtores. Mas, sendo programa de governo e não uma política pública, não houve continuidade. Na década de 2000, o Pró rural DF trouxe ênfase na produtividade com o incremento de tecnologia. Houve um aumento na produção de hortaliças e grandes culturas. A agricultura praticada no Distrito Federal passa a se caracterizar por alta produtividade e incremento tecnológico.

Porém, estudo das áreas rurais (ZEE,2009), figura 44, aponta proporção elevada de áreas com fragilidades ambientais.

Importante destaque ambiental na década de 1990 foi a definição da Reserva da Biosfera do Cerrado no DF. Porém ficou de fora do gerenciamento das APAS. Outra medida foi a criação da FLONA pelo governo federal. Visando proteger o Parque Nacional, enfrenta pressão por expansão urbana em suas áreas.

Ainda na questão ambiental, o rezoneamento da APA do São Bartolomeu, junto com a consolidação da área urbana de São Sebastião, inviabilizou a construção da barragem do São Bartolomeu. Por outro lado, viabilizou a legalidade dos processos de parcelamentos dos condomínios na área. 
Na década de 1990 é criada a Câmara Legislativa. Inicialmente, essa legisla concomitantemente e de forma desarticulada com o governo distrital.

O programa de assentamento de população de baixa renda do DF não supriu a demanda e serviu para incentivar o avanço de novas invasões. Visando tratar dos parcelamentos irregulares, são criadas leis e um grupo de trabalho (GET/PI)

Os PDOTs de 1992 e 1997 estabelecem macrozoneamentos estipulando delimitações para as áreas rurais e ambientais. Já o PDOT de 2009 altera áreas que eram destinadas a zona rural de uso diversificado para Zona Urbana de Expansão e Qualificação.

Em relação à ocupação espacial, o Distrito Federal foi gradativamente deixando de ter um padrão polinucleado de ocupação urbana e reforçando a ocupação ao longo dos grandes eixos viários/corredores de transporte, intensificando um processo de conurbação urbana.

A figura 49 indica três situações características do período: a conubação urbana, o avanço na produtividade agrícola e, a fragilidade e os agravos ambientais. 


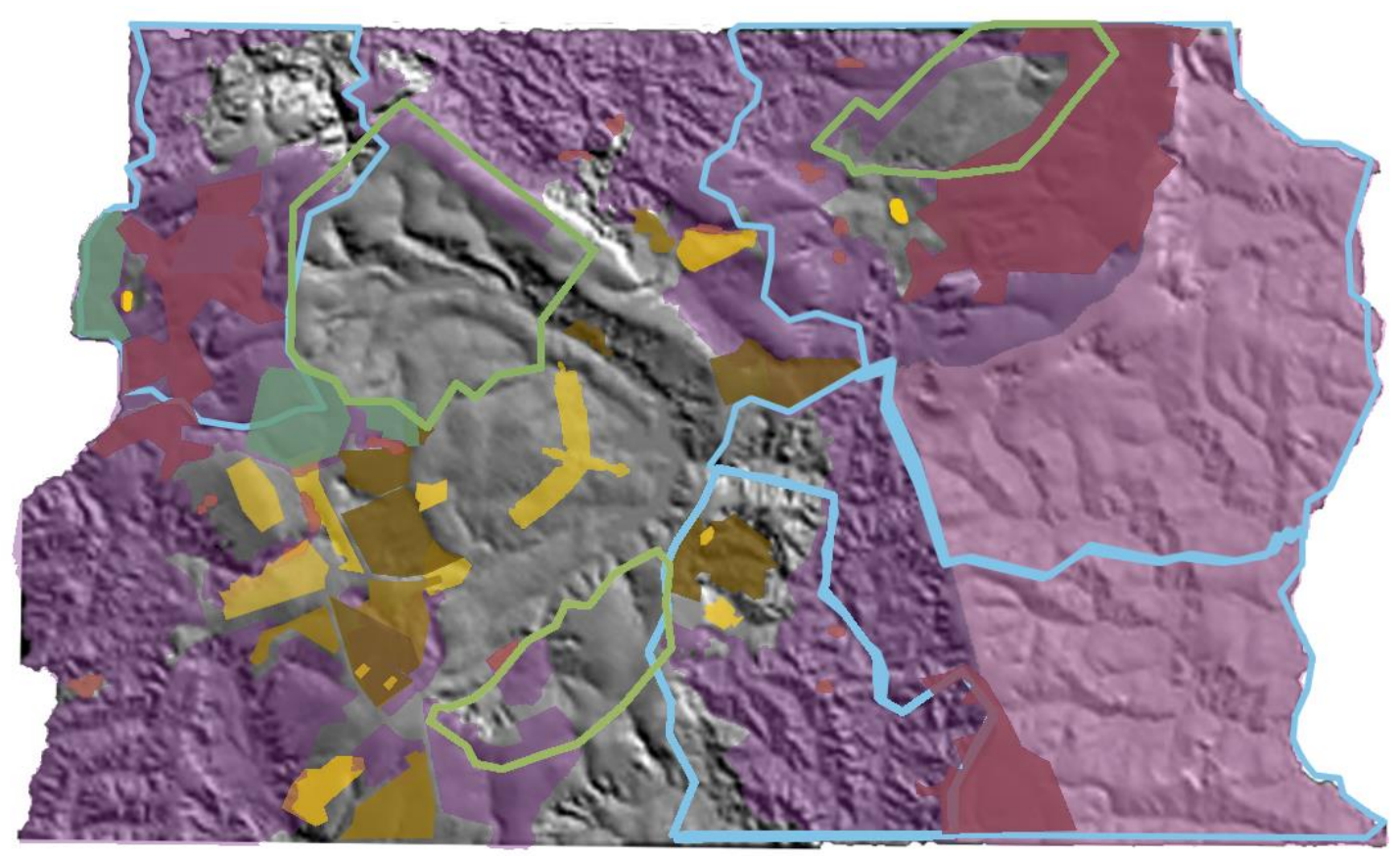

Década de 90

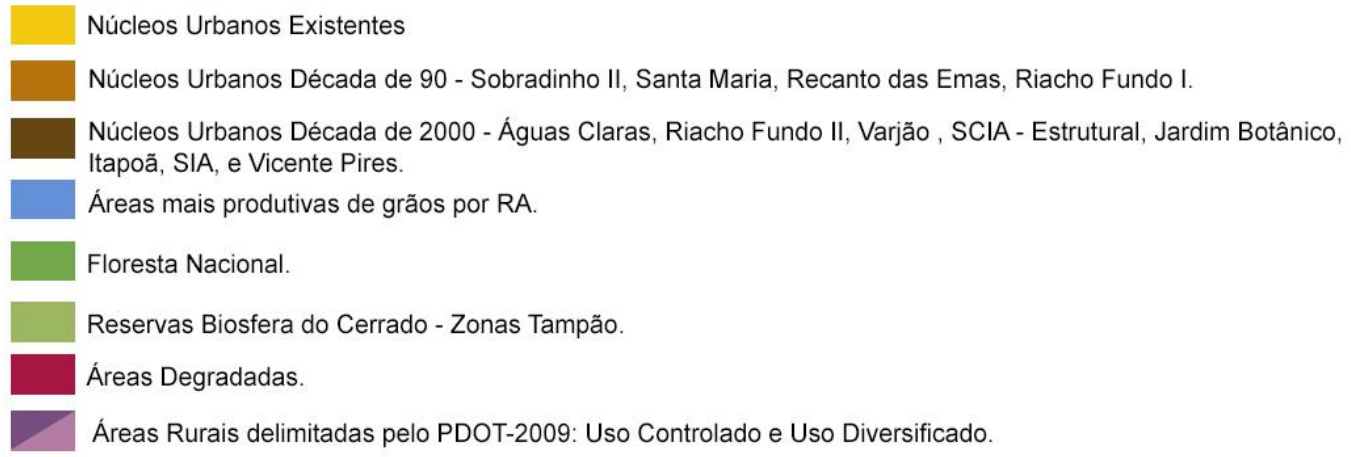

Figura 49: Desenho esquemático com a localização de alguns dos principais elementos do período - décadas de 1990 e 2000 - levantados nas categorias de análise. (Mapa base: SEDHU) 


\begin{tabular}{|c|c|c|c|}
\hline Aspectos Econômicos & Aspectos Ambientais & Aspectos Sociais & Aspectos Espaciais \\
\hline $\begin{array}{l}1995 \text { - Prove - } \\
\text { fortalecimento de } \\
\text { microempresas; } \\
\text { - } 1999 \text { - Plano de }\end{array}$ & $\begin{array}{l}1996 \text { rezoneamento da APA } \\
\text { do São Bartolomeu- } \\
\text { viabilizando condomínios, } \\
\text { inviabilizando a barragem; }\end{array}$ & $\begin{array}{l}\text { - Oficializados década de } 1990 \text { - Santa } \\
\text { Maria, São Sebastião, Recanto das Emas, } \\
\text { Riacho Fundo e Candangolândia } \\
\text { - maior número de invasões habitacionais - }\end{array}$ & $\begin{array}{l}\text { - Atuação da Câmara } \\
\text { legislativa; } \\
\text { - Variações na natureza } \\
\text { jurídica das terras; }\end{array}$ \\
\hline
\end{tabular}

Quadro 8: Síntese Décadas de 1990 e 2000 
Desenvolvimento Rural do Distrito Federal PRÓ-RURAL;

- predominância de Braslândia na produção de hortaliças e a vocação agrícola no leste do território;

- Pivôs de irrigação - Bacia do Rio Preto;

- alta produtividade e incremento tecnológico;
- 1994 - Reserva da Biosfera do Cerrado do Distrito Federal;

- Floresta Nacional de Brasília - FLONA;

- Intensidade de ocupação rural $x$ áreas degradadas.
Paranoá e São Sebastião (fixação de invasões):

- Estado criando assentamentos sem tratar o problema habitacional na dimensão requerida - Sobradinho II (política desapropriação de áreas rurais)

- processo de conurbação urbana com ocupação ao longo dos eixos viários:

- Oficializados década de 2000 - Águas Claras, Riacho Fundo II, Varjão, ParkWay, SCIA, Sobradinho II, Jardim Botânico, Itapoã e SIA e, Vicente Pires.

- Brasília metrópole
- PDOT 1992 acrozoneamento

- PDOT 1997 -delimitações para as áreas rurais e ambientais;

- $\quad$ PDOT 2009 - Duas definições para áreas rurais; 


\section{ANÁLISE DOS RESULTADOS}

A intenção desse capítulo é trazer contribuições ao debate rural-urbano a partir da análise de situações das áreas rurais do Distrito Federal. Aborda questões históricas, conceituais, o quadro atual e tendências futuras.

Para a discussão dos resultados faz-se uma análise empregando dados levantados ao longo da pesquisa. Aborda as configurações sócio-espaciais formadas ao longo das décadas analisadas, revisando o referencial teórico. Há também, um exercício de conjecturas futuras para o DF, utilizando os elementos de análise elaborados na metodologia.

\subsection{Configurações espaciais atuais das áreas rurais do DF}

Atualmente, o Distrito Federal se encontra dividido em 31 regiões administrativas. Sua área total corresponde a $5.779,999 \mathrm{~km}^{2}$, sendo $4.213,520 \mathrm{~km}^{2}$ ou 421.352,00 hectares (74\% do total) de área rural. Os dados do censo do IBGE de 2010 apontam para $96,6 \%$ da população no meio urbano e, $3,4 \%$ no meio rural.

Conforme definido pelo site da CAESB: A população rural do Distrito Federal está distribuída em grandes fazendas, sítios, chácaras, vilas e agrovilas, sendo terras particulares ou públicas, e colônias agrícolas organizadas pelo Governo Federal. (CAESB, 2015). A figura 50 apresenta a atual distribuição das glebas rurais no Distrito Federal. 


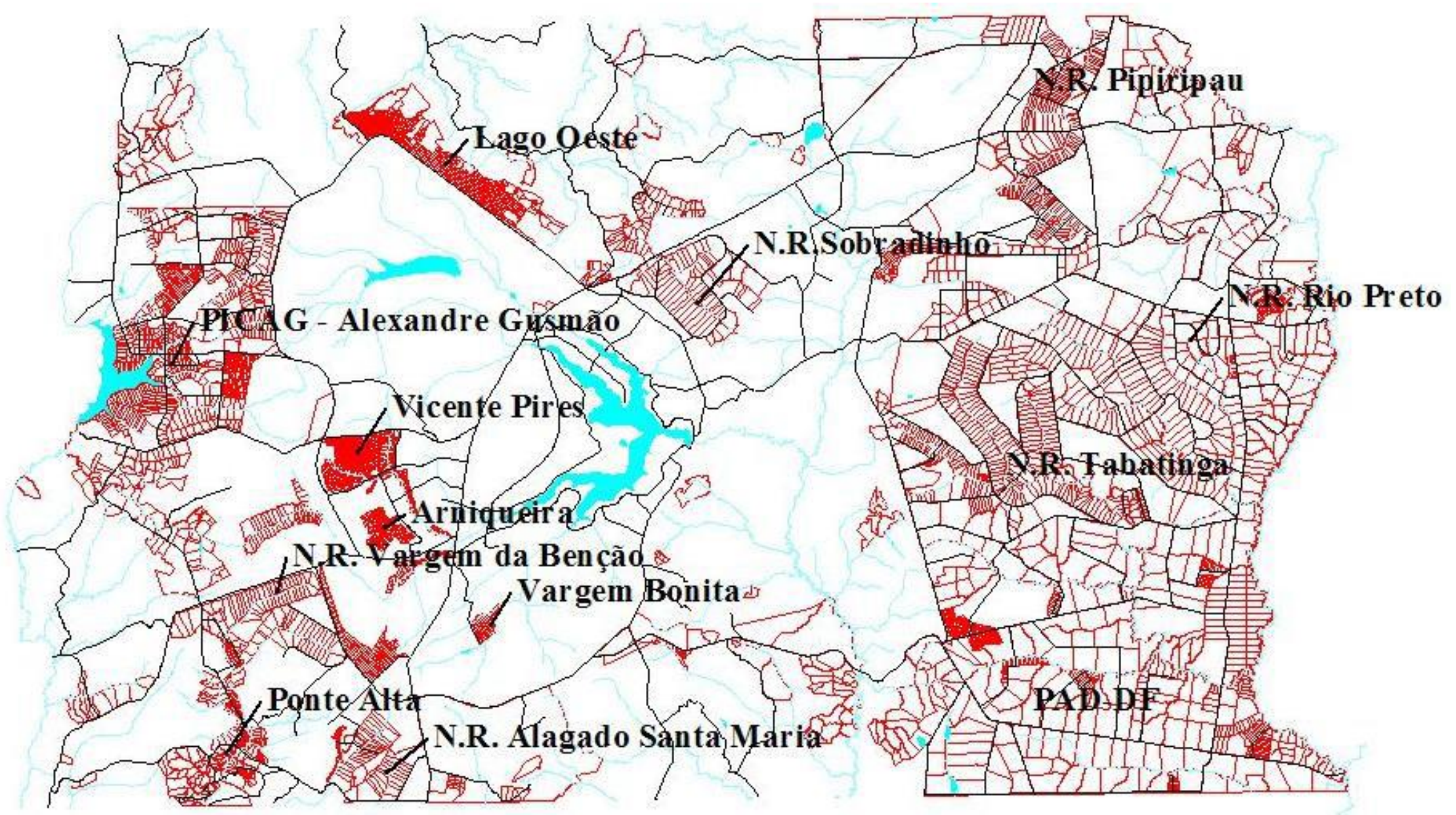

Figura 50: Indicação das glebas rurais existentes no Distrito Federal (em vermelho) fonte: ZEE, 2009 
Em linhas gerais, os padrões de ocupação e usos das áreas rurais no Distrito Federal compreendem:

- Pastagem. Exemplo: Região de Cava de Baixo, fronteira sul do DF, ladeando o Rio São Bartolomeu;

- Agricultura intensiva (Utilização de práticas mecanizadas, insumos e implementos agrícolas). Ex.: PAD-DF - área a leste de Planaltina;

- Hortifrutigranjeiros. Ex.: Área da Vargem Bonita no Park Way e Braslândia;

- Áreas Irrigadas. Ex.:Região de Barreiro, fronteira centro sul do DF;

- Chácaras de Uso Diversificado láreas ocupadas por diferentes atividades envolvendo agricultura familiar, chácaras de lazer). Ex.:parte do Núcleo Rural Bonsucesso, a noroeste da ESEC de Águas Emendadas;

- Aglomerado Agrourbano (área urbana isolada em zonas rurais). Ex.:Bacia do rio Preto no DF.

Ao longo dessa pesquisa, nos recortes temporais e no emprego das variáveis de análise, foram observadas distintas configurações dos espaços rurais no DF. São elencadas a seguir, algumas áreas rurais que ilustram variações nas transformações ocorridas nestes espaços. Longe de abordar todas as transformações ocorridas, buscase destacar processos característicos. Para ilustrar a análise são empregadas fotografias aéreas, selecionadas no período dos anos pesquisados, obtidas em páginas oficiais do $\mathrm{GDF}^{26}$. Compreendem:

- A Vargem Bonita como enclave de área agrícola;

- As áreas rurais de Sobradinho enfatizando os processos de expansão urbana oriundos de políticas públicas e a pressão do mercado habitacional;

- A região de Vicente Pires ilustrando questões ambientais e habitacionais;

- Núcleos Rurais Taguatinga, Vargem da Benção e Monjolo - enfatizando as influências das áreas urbanas próximas.

As imagens foram adaptadas de fotografias aéreas obtidas ao longo dos anos. Devido à variações nos ângulos e tomadas das fotos elas serão apenas ilustrativas, ficando impossibilitada sua sobreposição para análise. Fonte: http://www.sedhab.df.gov.br/preservacao-e-planejamento-urbano/gestao-dainformacao-urbanas/mapas.html 


\section{Núcleo Rural Vargem Bonita}

Também conhecido como Núcleo hortícola Vargem Bonita, foi criado em 1957, antes da inauguração de Brasília, com o intuito de abastecer a população com hortaliças. Os pioneiros, de origem japonesa, vieram predominantemente de São Paulo, o que se mantém até hoje. Situada, no Park Way, próximo ao aeroporto, a comunidade faz divisa a leste com o córrego Ribeirão do Gama, a oeste com córrego Mato Seco, ao norte com o SMPW e ao sul com a FAL (Fazenda Água Limpa).

Sob a ótica econômica, segundo dados da EMATER, as propriedades, na sua maioria, são exploradas com hortaliças folhosas, em sistema convencional. Há também o cultivo de plantas medicinais, floricultura, produção de cogumelo, broto de feijão, produção orgânica, processamento de frutas e hortaliças e agroindústrias. Na horticultura, o uso da mão de obra é intenso, empregando os trabalhadores e suas famílias por propriedade. A forma individual de comercialização encontra entraves no elevado custo do transporte e baixo valor da mercadoria. Outros fatores limitantes são o envelhecimento da população e o tamanho reduzido das propriedades. Pontos positivos da comunidade são a proximidade com o mercado consumidor e a diversificação da produção (verticalização, floricultura).

A comunidade de Vargem Bonita talvez seja o caso mais emblemático das áreas rurais do DF; estando próxima ao Plano Piloto se mantém agrícola e produtiva, numa região onde o preço da terra é elevado. Algumas hipóteses foram levantadas na busca de entender esse processo:

- Traços histórico-culturais - é formada em sua maioria por uma comunidade de japoneses o que propicia vínculos históricos e culturais no pertencimento a uma comunidade.

- Apoio à produção - Desde sua criação sempre houve apoio governamental à produção. Há um escritório da Emater nas imediações.

- Limitações geográficas - Para se chegar ao local é preciso passar pelo Park Way e é uma área triangular delimitada por rios o que a transformou numa espécie de 'gueto'. 
- Área agrícola diferenciada - O tipo de solo e o nível elevado do lençol freático tornaram a área propícia à agricultura, especificamente de hortifrúti. Em pequenas parcelas agrícolas se obtém variedade produtiva, com emprego de elevado número de mão de obra envolvendo mão de obra familiar.

Comunidades que se fixam por um bom tempo como enclaves rurais em áreas urbanas, como é o caso da Vargem Bonita, necessitam de acompanhamento por parte dos órgãos gestores e são importantes elementos de análise por parte dos estudiosos do planejamento urbano/municipal.

As imagens da figura 51 ilustram a ocupação espacial de Vargem Bonita ao longo das décadas. Observa-se sua delimitação pelos elementos naturais (áreas de proteção ao longo dos rios) e a intensificação da produção agrícola. 


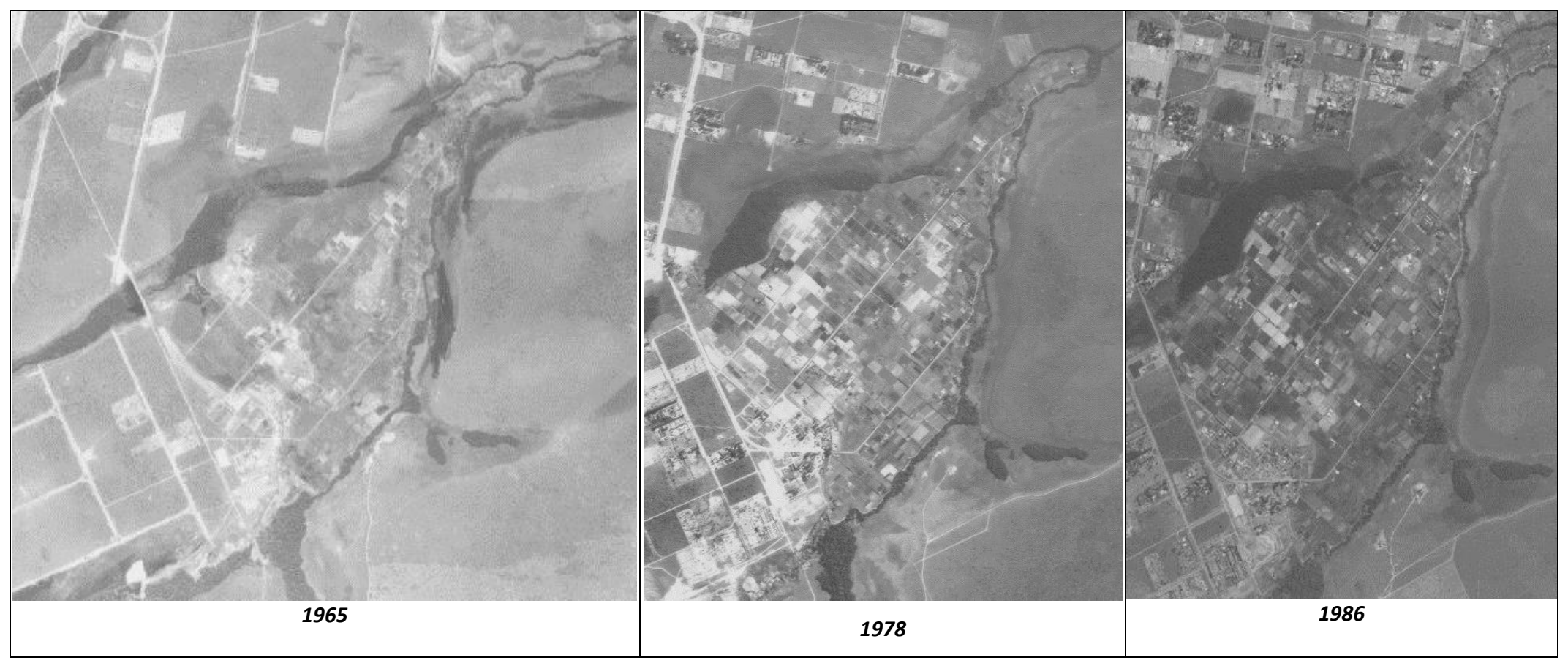




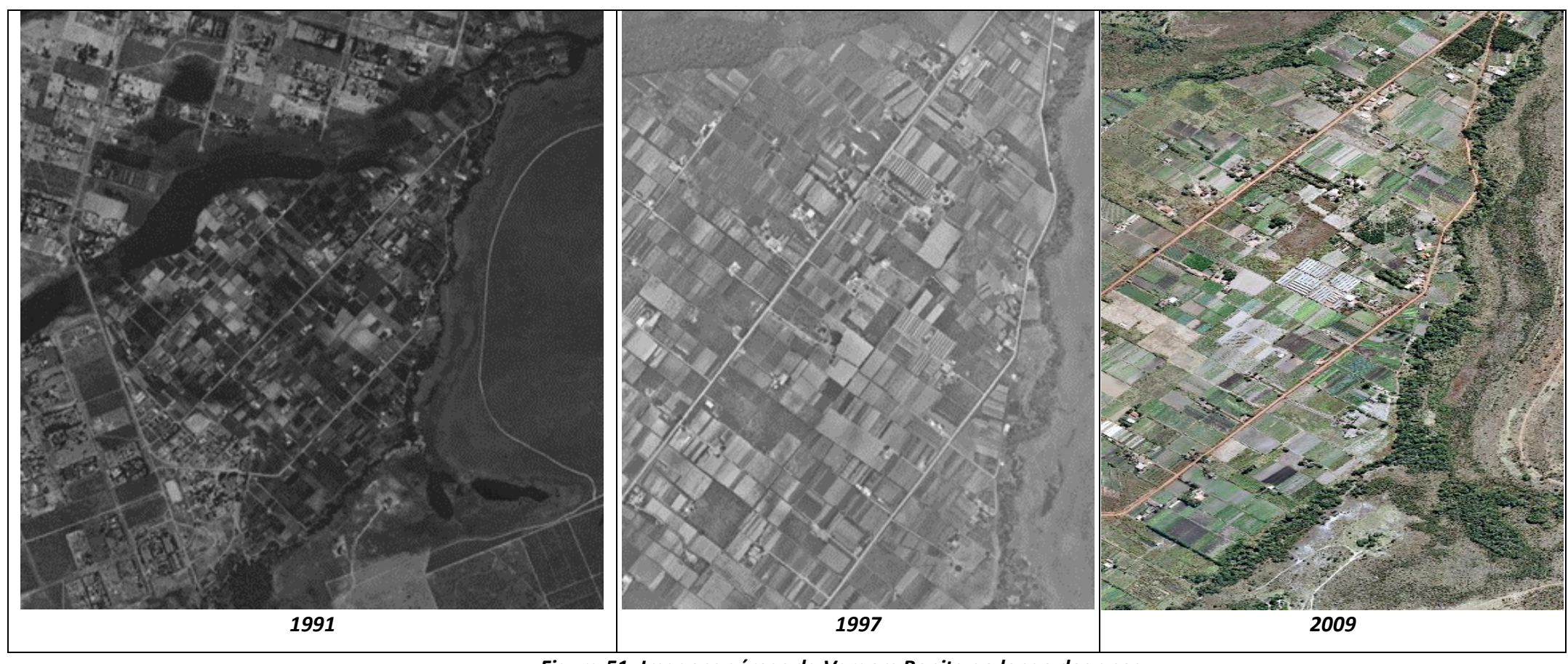

Figura 51: Imagens aéreas da Vargem Bonita ao longo dos anos 


\section{Áreas rurais de Sobradinho}

A verificação das áreas rurais de Sobradinho enfatiza os processos de expansão urbana oriundos de políticas públicas e a pressão do mercado habitacional. Sobradinho nesta abordagem corresponde às atuais Regiões Administrativas de Sobradinho I e II e a Fercal. As situações levantadas correspondem a generalizações e tendências do processo de transformações de áreas rurais. Não faz parte da abordagem o detalhamento minucioso de cada situação.

Sobradinho II - A transformação em área urbana envolveu, neste caso, decisão governamental, desapropriando área rural e criando loteamento urbano para atender à demanda habitacional de baixa renda.

Nova Colina - 'O Setor Habitacional Nova Colina é formado por um grupamento de glebas da Fazenda Sálvia, imóvel rural de propriedade pública federal, cuja maior parte está localizada em Sobradinho' (Silva, 2011). Envolve: transformação de áreas rurais em urbanas por meio de loteamentos e ocupações irregulares; população com perfil característico inicial de baixa renda tendendo para média renda; caracteriza processos de ocupações próximo a grandes eixos viários.

Condomínio Alto da Boa Vista - Característico de especulação imobiliária envolvendo parcelamento de área rural particular para fins urbanos. Há indefinição na titularidade da terra e problemas ambientais devido à proximidade de nascentes.

Lago Oeste - Delimitado como área rural. A maioria dos terrenos do Lago Oeste ficam em terrenos da União e possuem em média 2 hectares. Há produtores rurais, porém, caracteriza-se por chácaras de moradia e lazer. Representa um processo de ocupação de áreas rurais para habitação de classes de renda média, sem necessariamente representar adensamento num processo de urbanização.

Condomínios de Sobradinho - Os condomínios de Sobradinho em sua maioria, encontram-se nas proximidades de Sobradinho II e da BR 010 até o Balão do Colorado. Representam adensamentos urbanos para fins de moradia em áreas rurais.

Com exceção do Lago Oeste, as demais áreas citadas correspondem a áreas urbanas atualmente. Apresentam pendencias ou estão em processo de regularização. 
Nos Planos de ordenamento observa-se uma mudança paulatina dessas áreas de rural para urbano. Isto ocorre não como proposta de planejamento, mas como tentativa de ordenar tendências de expansão urbana.

As áreas rurais próximas à cidade de Sobradinho, apresentadas na fig. 52, encontram-se cercadas por essa mancha urbana.

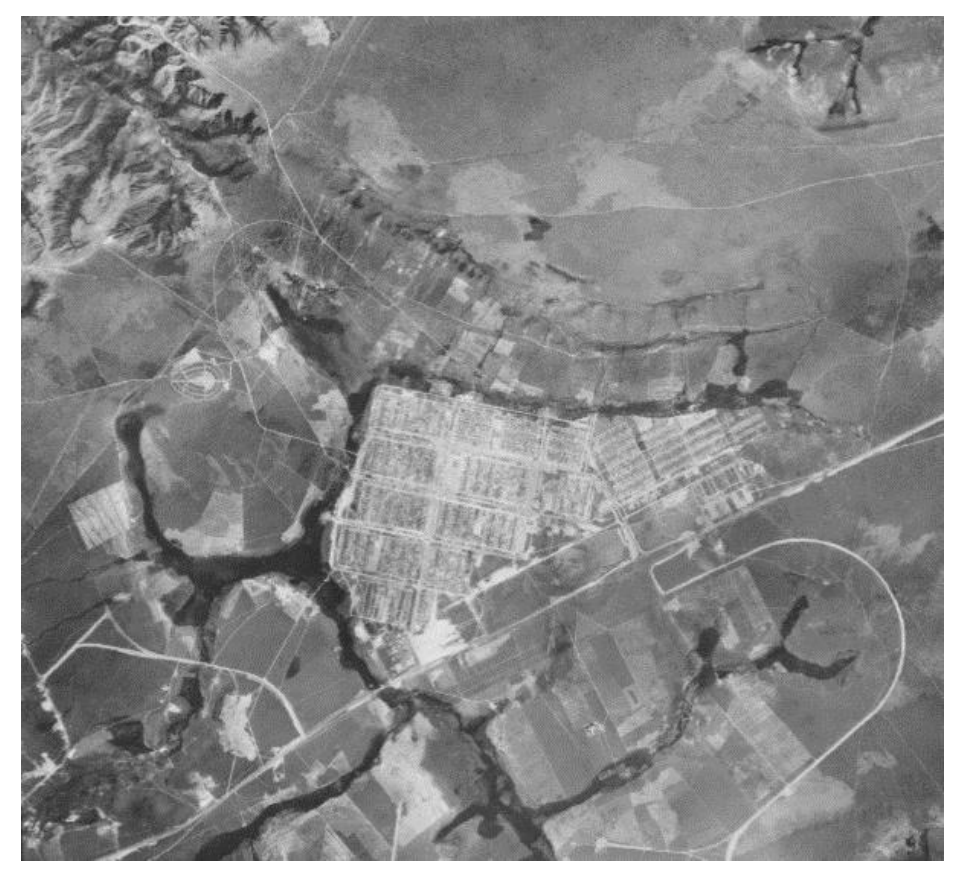

a) 1965 


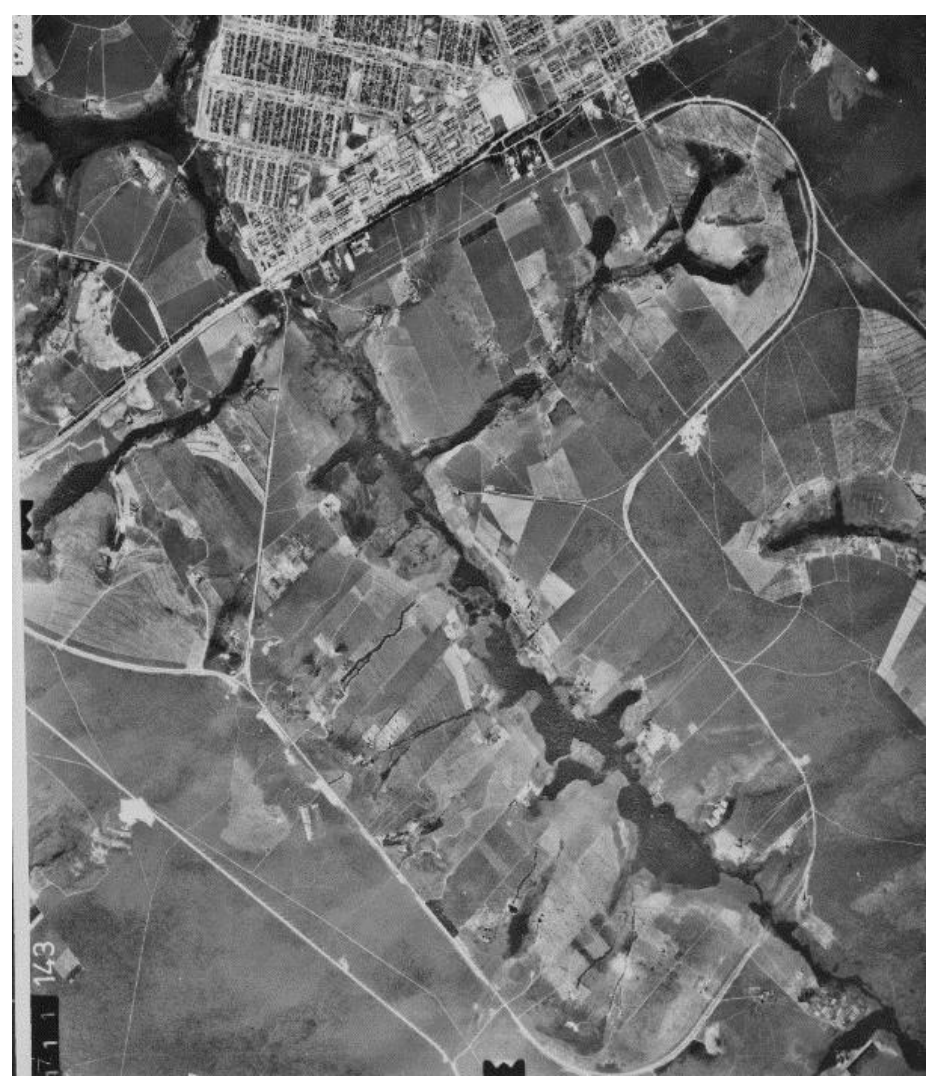

b) 1975

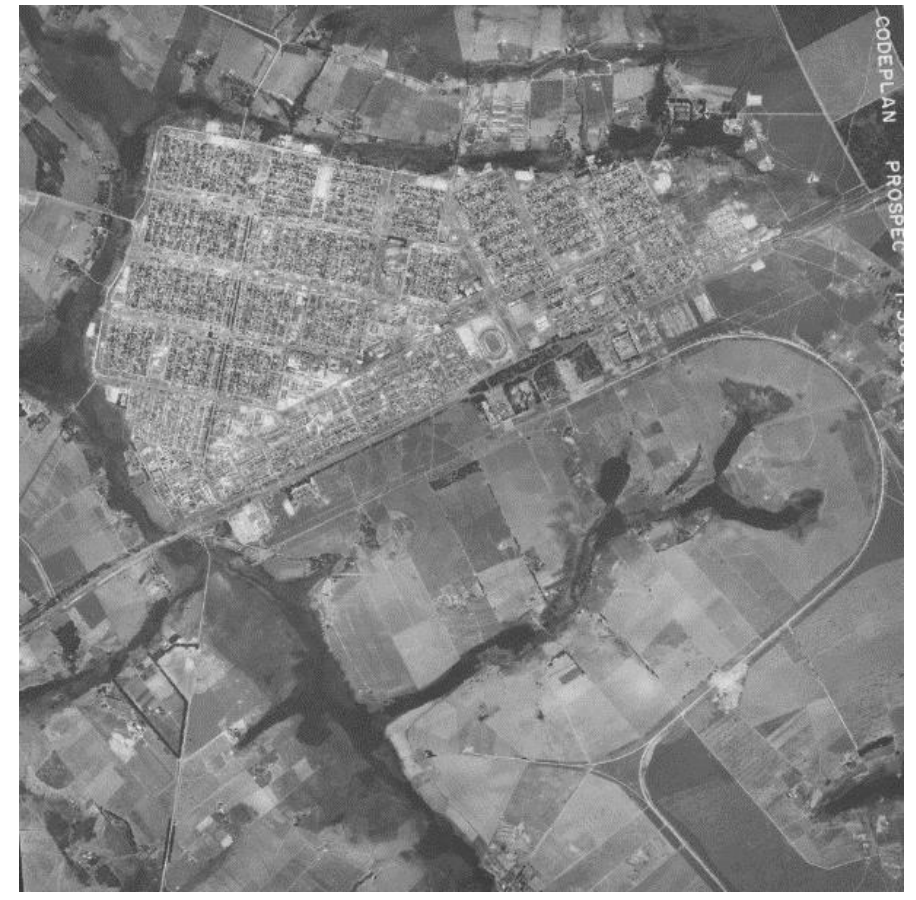

c) 1986

Figura 52: Imagens aéreas de Sobradinho ao longo dos anos

\section{Vicente Pires}

A região de Vicente Pires ilustra alterações rurais envolvendo loteamentos urbanos e questões ambientais. 
Conforme verificado na análise da primeira década, a região do Vicente Pires já era uma área de invasão de chacareiros ao longo do leito do rio. Na década de 1990 há um adensamento da ocupação irregular, ainda de caráter rural.

Como pode ser observado nas imagens das figuras 53 e 54, com o passar dos anos, estas chácaras foram sendo parceladas em condomínios fechados. O desenho urbano que acabou se conformando nesse processo é inadequado às características físicas e geológicas do terreno.

Esse processo de urbanização desconsiderando as limitações locais provocaram agravos ambientais e sociais difíceis de serem sanados.

Os problemas decorrentes desse processo de subparcelamento de glebas rurais, que poderia ser considerado normal (e até inevitável) na perspectiva do desenvolvimento urbano do DF (dada as altas taxas de seu crescimento urbano), podem ser resumidos em três aspectos: ocupação indevida de áreas legalmente protegidas (áreas de preservação permanente), a redução da atividade e da produção agrícola; e a expansão da malha urbana sem o acompanhamento dos devidos sistemas de infraestrutura. (ZEE,2009)

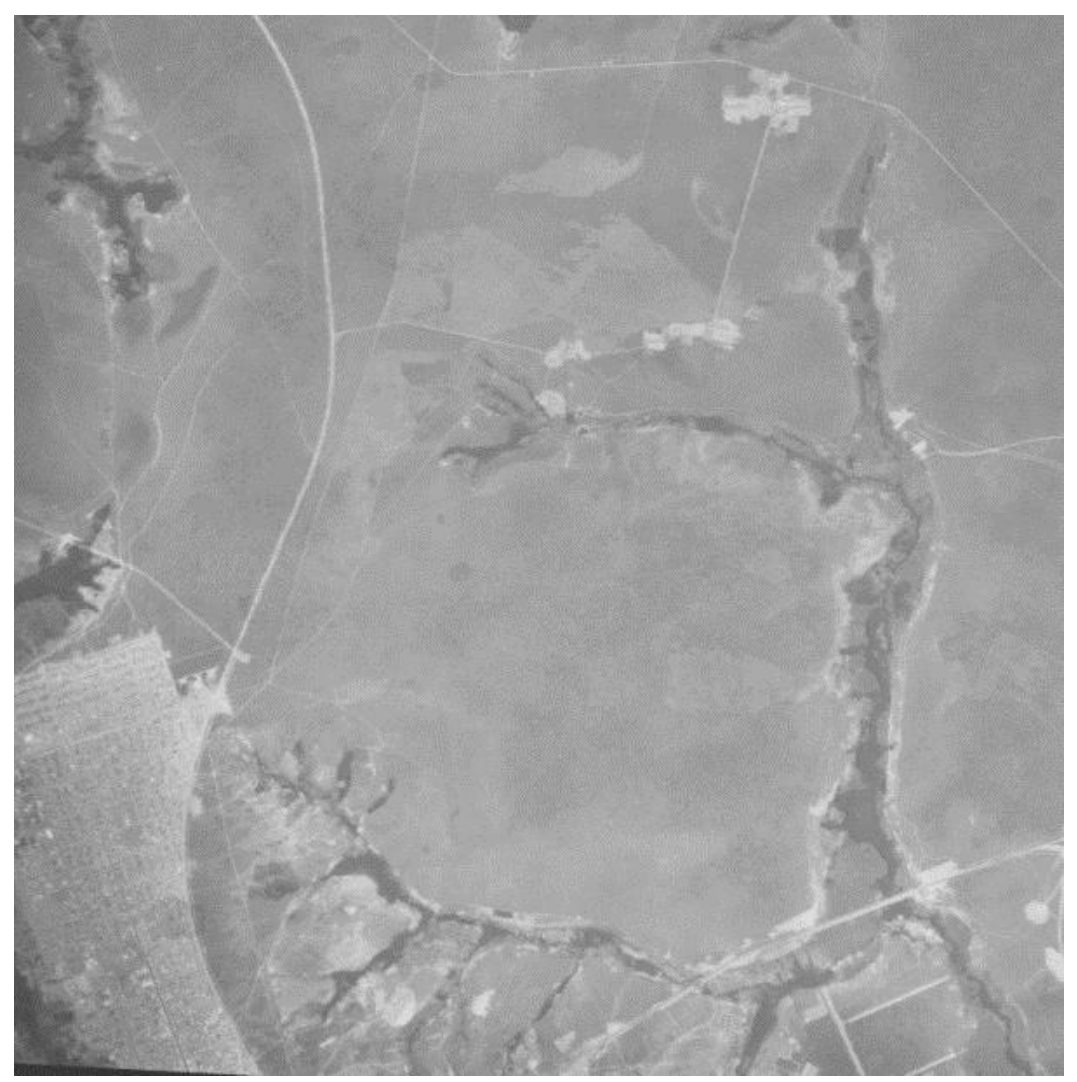

a) 1964 

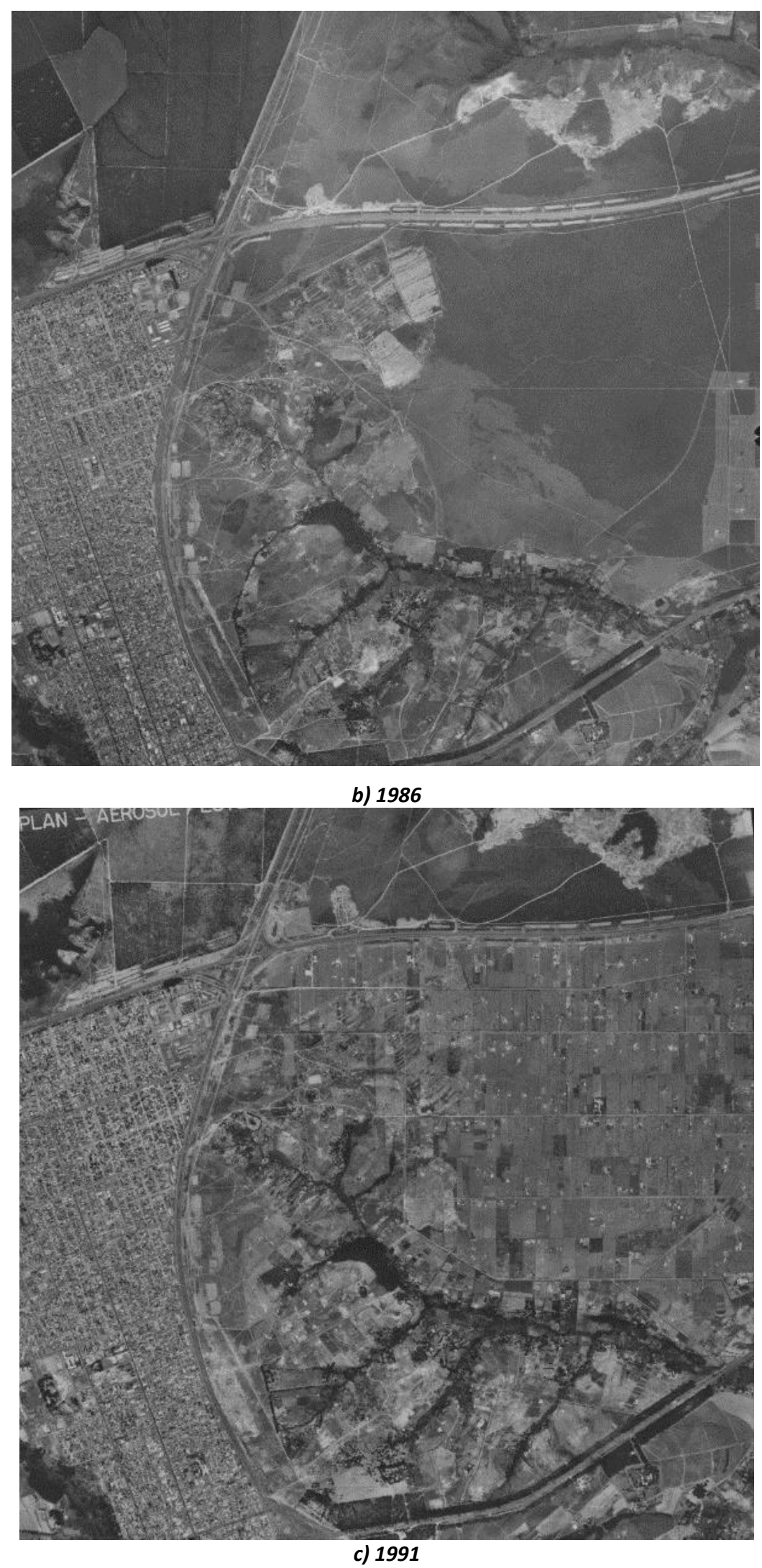


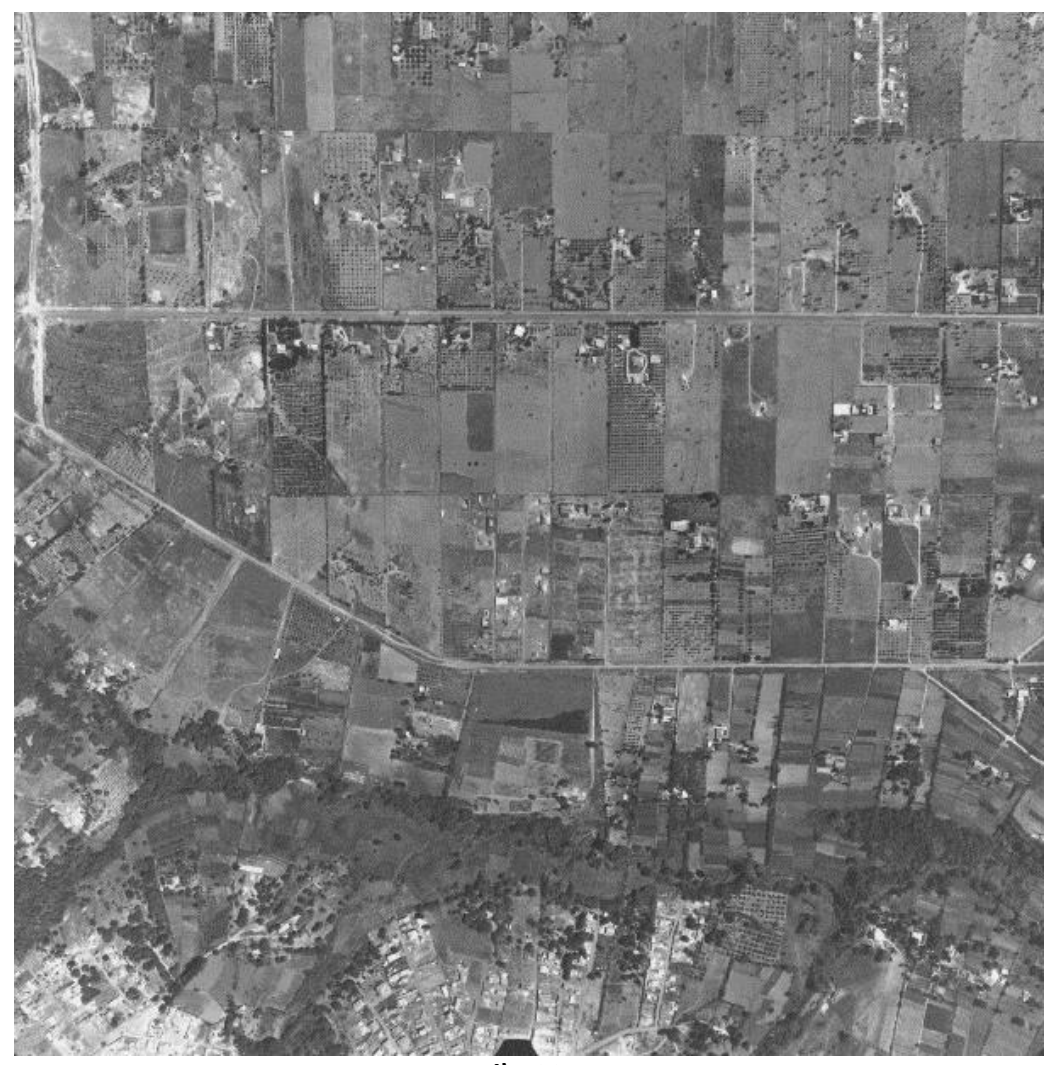

d) 1997

Figura 53: Vicente Pires 1964, 1986, 1991, 1997

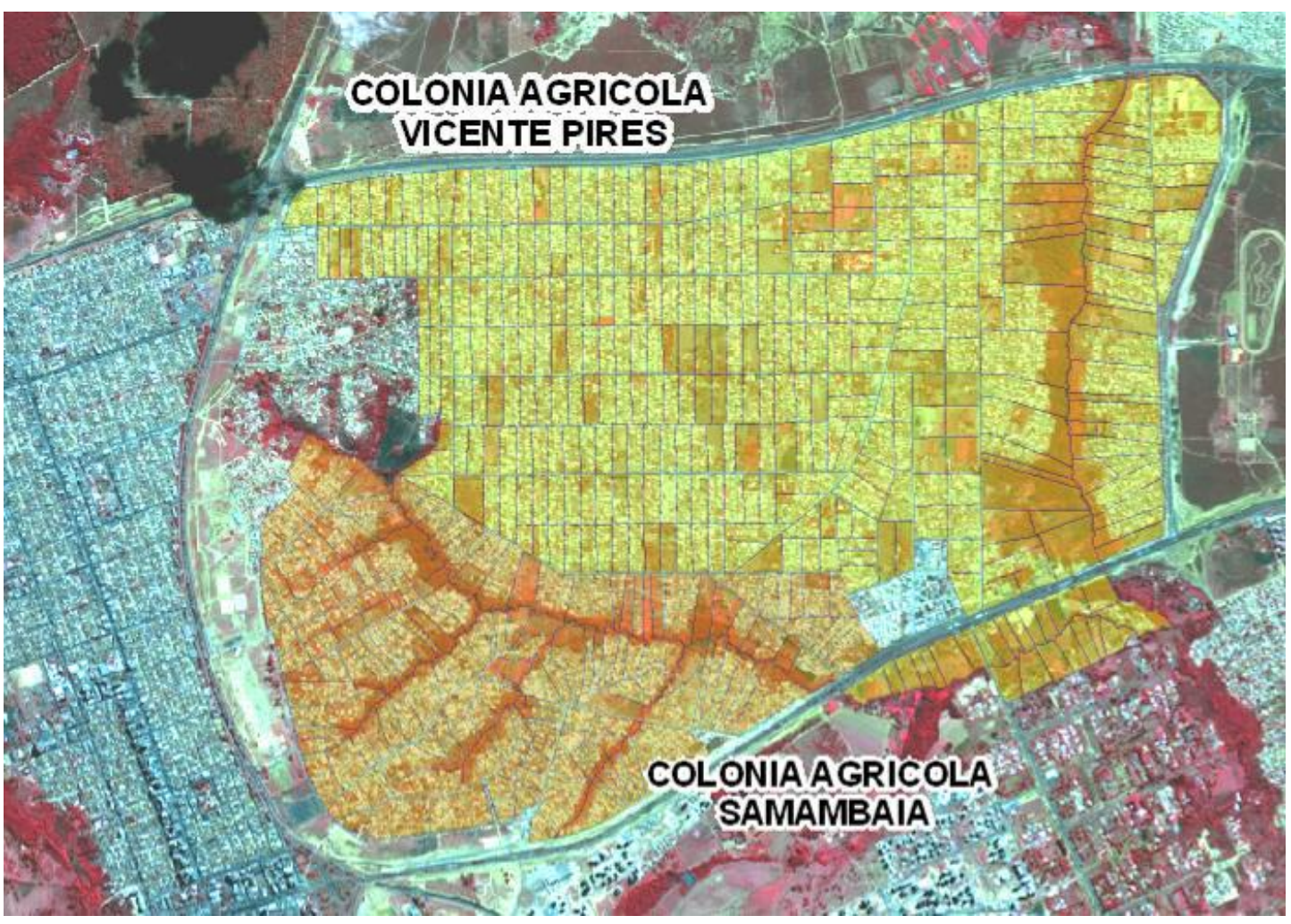

Figura 54: Vicente Pires 2009 - fonte: ZEE (2009) 


\section{Núcleos Rurais Taguatinga, Vargem da Benção e Monjolo}

A escolha dos Núcleos Rurais Taguatinga, Vargem da Benção e Monjolo busca enfatizar as influências das áreas urbanas próximas. As três regiões são antigas áreas rurais do Distrito Federal, situadas próximas à núcleos urbanos adensados e, no principal vetor de crescimento urbano do DF.

As informações dos Núcleos Rurais foram baseadas em dados da Emater de 2009. Já neste período se observa a interferência das áreas urbanas no direcionamento das atividades desenvolvidas nestes locais. Uma hipótese para a permanência/sobrevivência como áreas rurais é sua criação por meio de programas governamentais e, o fato de boa parte estar em terras públicas de domínio da Secretaria de Agricultura.

Núcleo Rural Taguatinga - O Núcleo Rural Taguatinga é um dos mais antigos assentamentos rurais do Distrito Federal, visava à produção de alimentos para atender a Capital Federal em implantação. Constituído inicialmente por japoneses e descendentes, atualmente há outros produtores. Também sofre grande influência da área urbana. Dados da Emater de 2009 já apontavam, além de atividades agrícolas (olericultura, floricultura, agricultura orgânica, bovinocultura leiteira, agroindústria e turismo rural), outras relacionadas à sua localização estratégica próximo a área urbana (salões de festa, campos de futebol para aluguel, etc).

Núcleo Rural Vargem da Benção - O Núcleo Rural vargem da Benção corresponde à propriedades rurais localizadas entre as cidades satélites de Samambaia e Recanto das Emas, margeando os dois lados do córrego Vargem da Benção. Dados da Emater de 2009 caracterizavam as propriedades em terras públicas, com direito de domínios regularizados ou não junto à SEAPA/Terracap. As propriedades ou lotes variam entre 2,00 e 80,00 ha. Os lotes menores nas áreas de posse ou remanescentes da área de instalação da cidade de Recanto das Emas e, os lotes maiores, na área de arrendamento e/ou concessão de uso originais ou transferidos, às margens da BR060/Samambaia. As atividades observadas foram pecuária, lazer, prestação de serviços, olericultura e agricultura, ocorrendo também atividades de filantropia, ensino 
e lazer. Entraves: a proximidade com a área urbana e a questão da regularização fundiária.

Núcleo Rural Monjolo - Localizado no Recanto das Emas, as propriedades são de concessão de uso da SEAPA, com propriedades acima de 20,00 ha, apresentando uma boa geração de emprego na região, principalmente pelas agroindústrias ali instaladas. As principais explorações são a pecuária, olericultura, fábrica de ração, incubatório e agroindústria de beneficiamento de leite. As explorações agrícolas ocorrem no segmento patronal, e algumas variações no segmento familiar, principalmente na exploração de olericultura. As principais vocações são pecuária, agricultura, olericultura, agroindústria e exploração mineral com produtores de padrão financeiro relativamente alto. Seus principais entraves para a atividade agrícola são a proximidade com a área urbana e vários locais de afloramento de lençol freático.

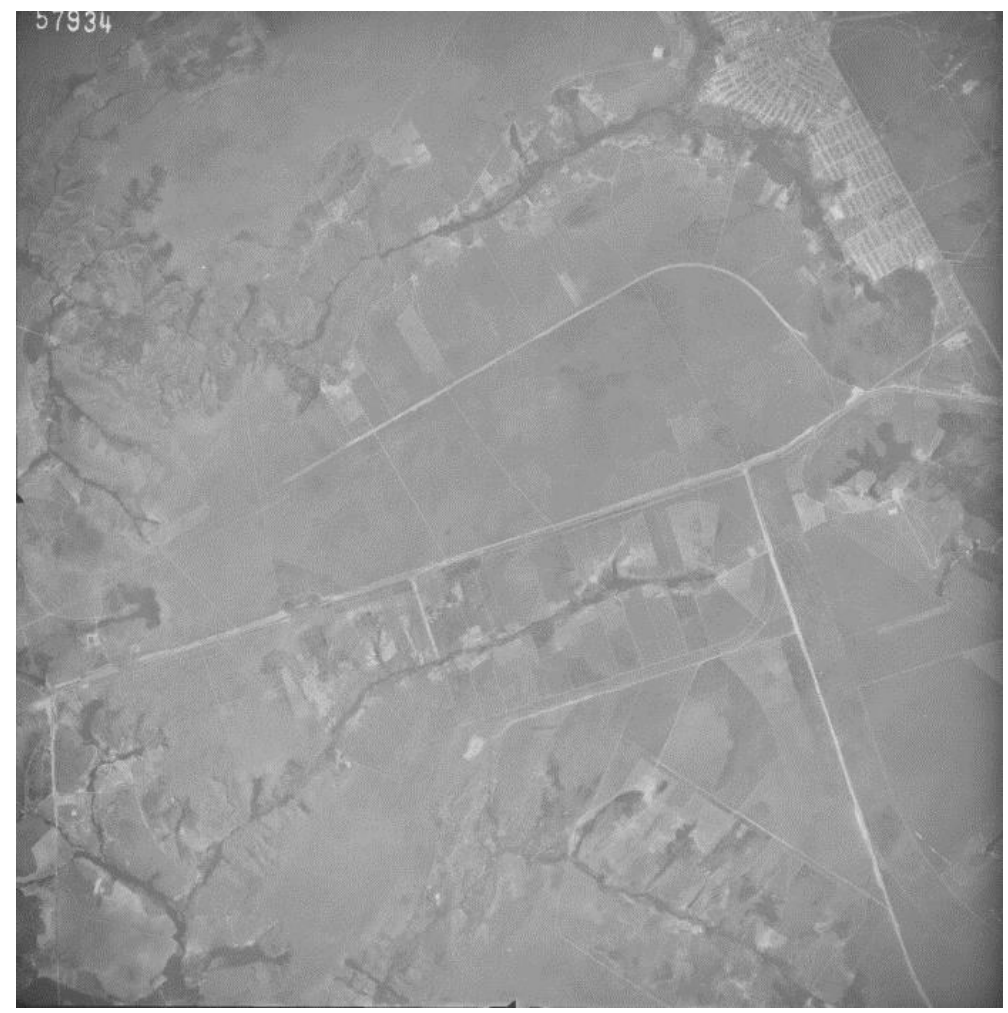

a) 1965 


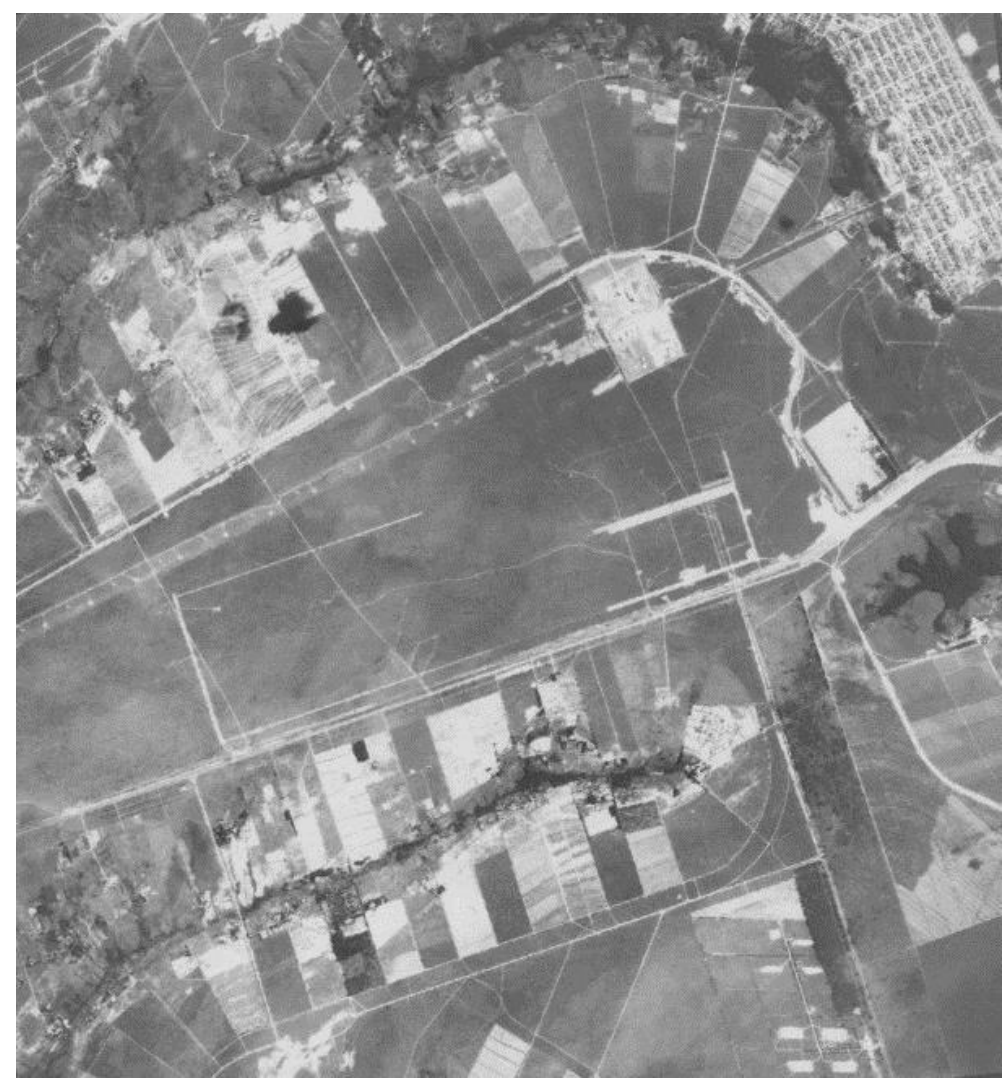

b) 1978 Taguatinga e Vargem da Benção 


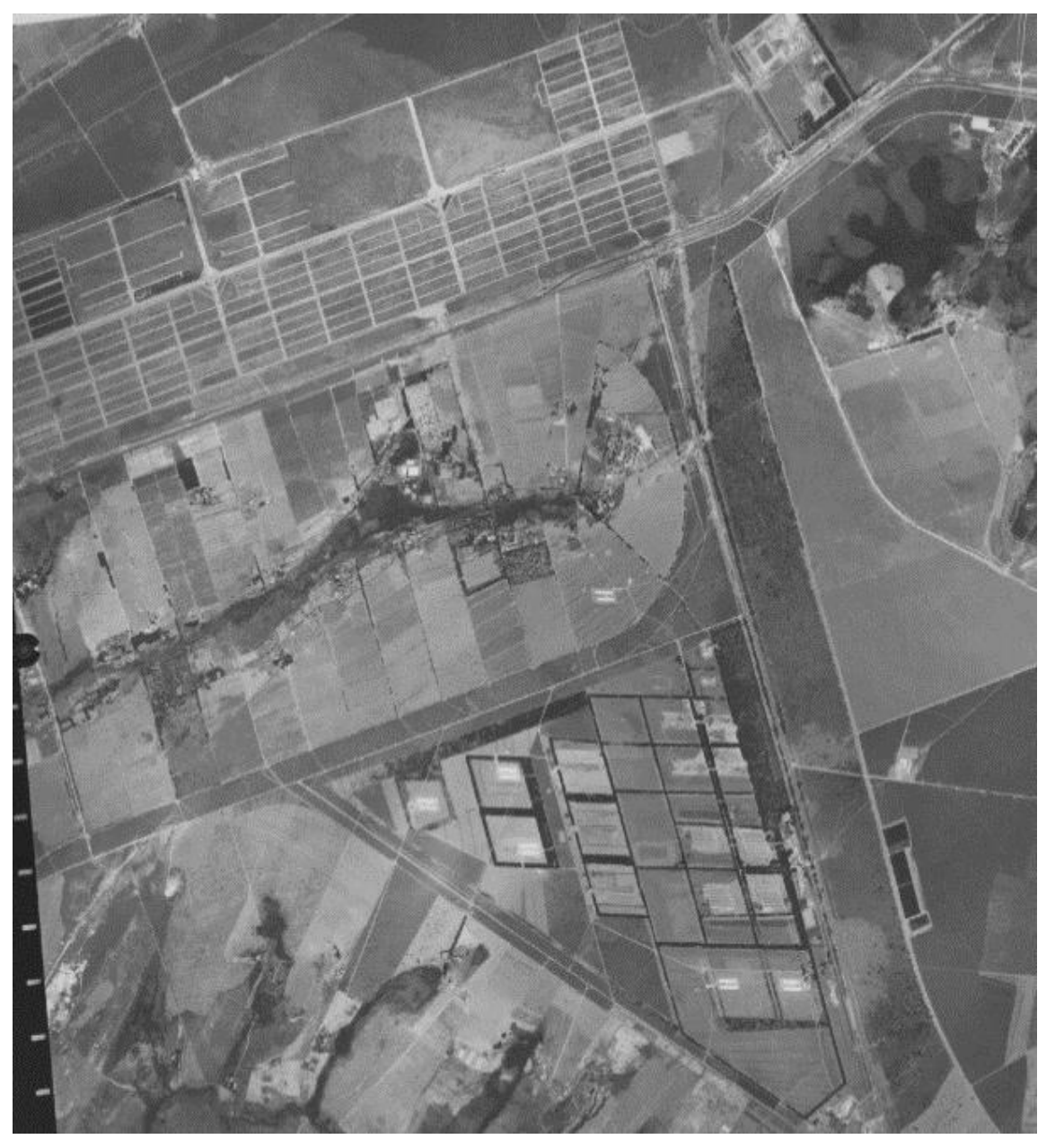

c) 1986 Vargem da Benção e Monjolo

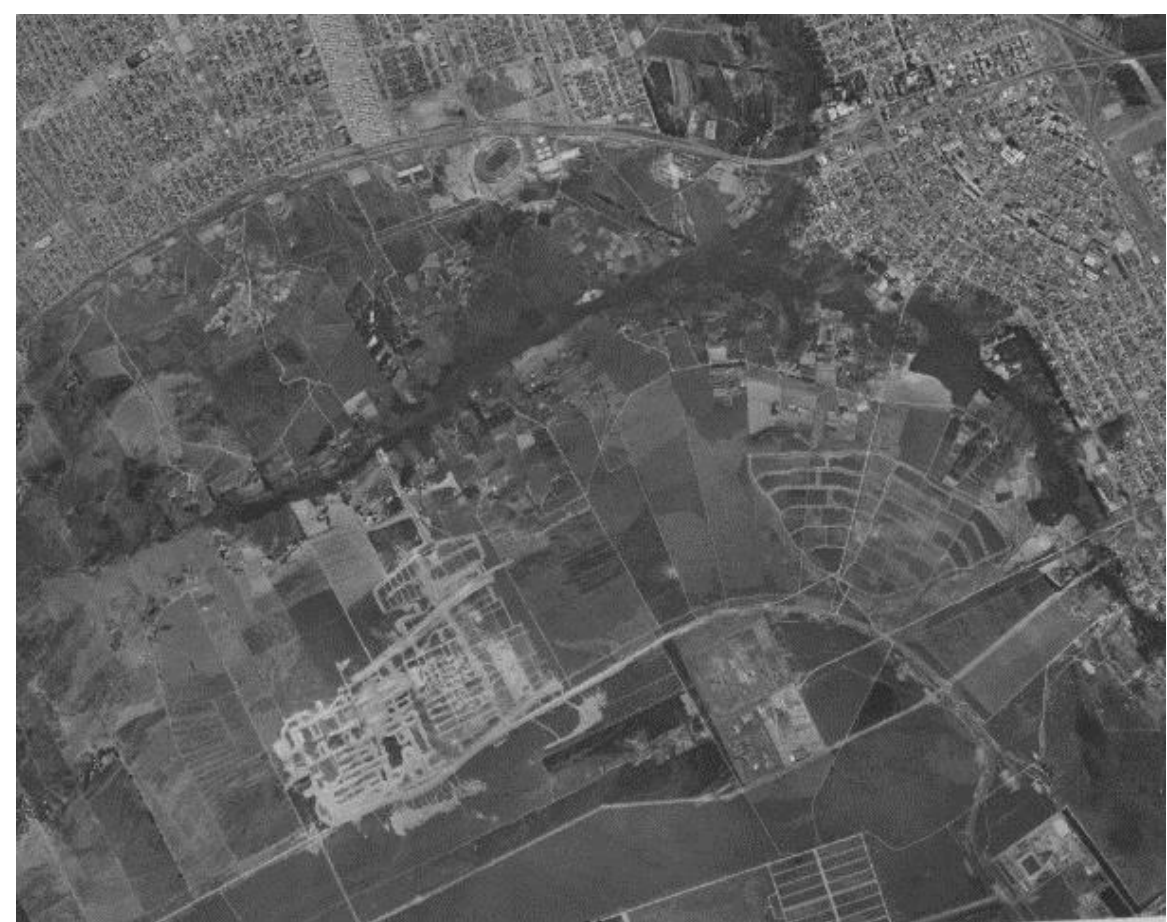

d) 1986 Área rural de Taguatinga 


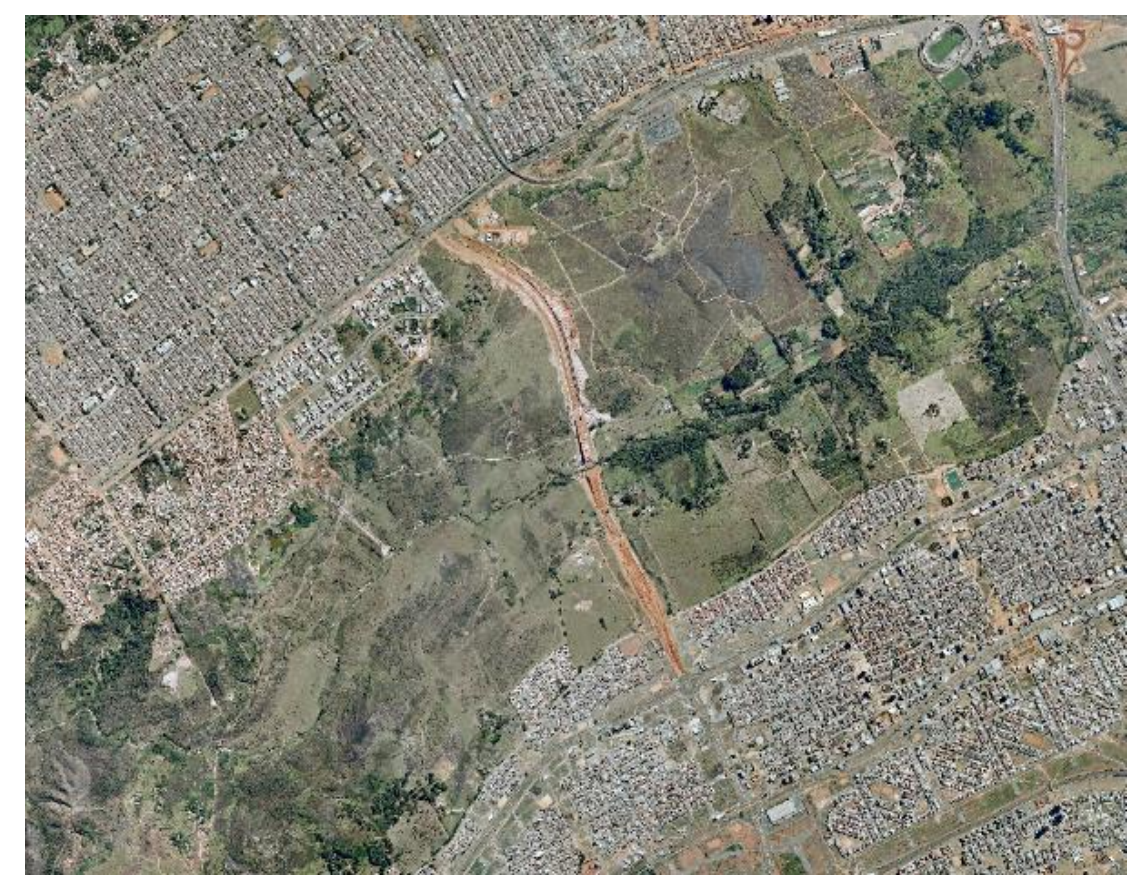

e) 2009 Área rural de Taguatinga, entre Ceilândia e Samambaia

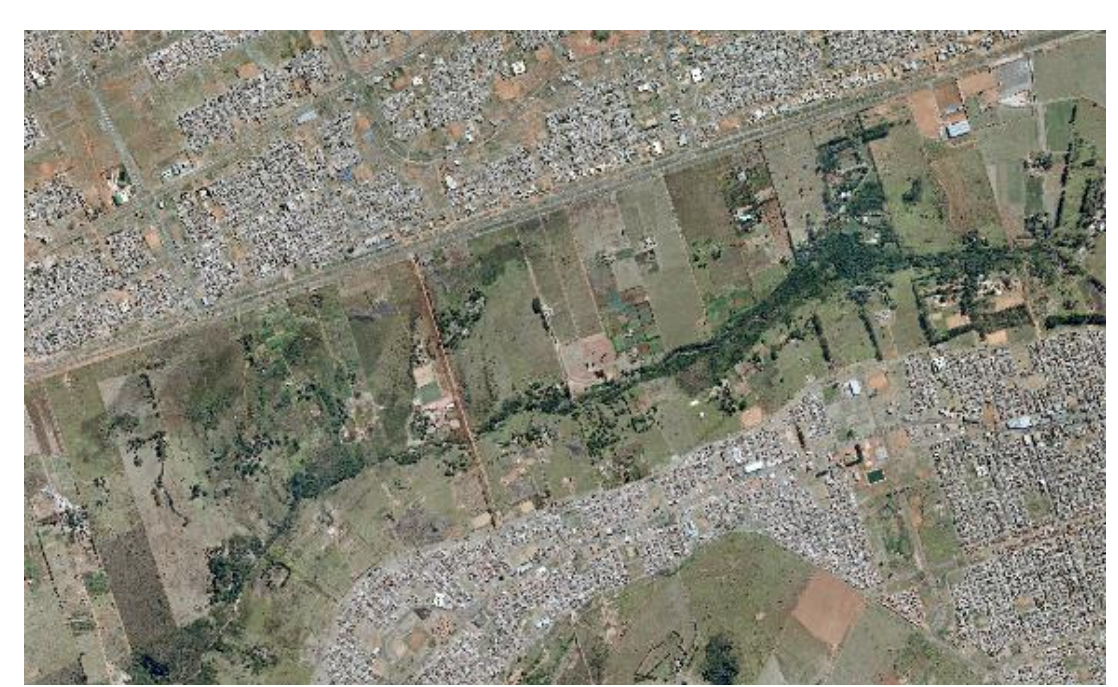

f) 2009 Vargem da Benção Figura 55: Taguatinga, Vargem da Benção e Monjolo de 1965 a 2009 
A situação dessas três áreas é bem visualizada nas análises de Botelho Filho (2001) ao afirmar que as atividades econômicas na área rural tiveram que competir com a rentabilidade obtida com a valorização da terra. Afirma que o crescimento mais dinâmico nas áreas rurais se dá nas atividades não agrícolas (turismo rural e ecológico, restaurantes, aglomerações residenciais). As atividades agrícolas que predominam são aquelas que proporcionam elevadas rentabilidades devido aos investimentos em capital e técnicas. Considera ainda que as atividades pecuárias são exercidas como atividades secundárias das propriedades agrícolas, na espera da valorização com a transformação de área rural para urbana no futuro.

\section{Demais áreas rurais relevantes}

Apesar de não estarem no levantamento acima, outras áreas rurais apresentam peculiaridades relevantes a ser acrescentadas na análise. 0 acompanhamento de imagens ao longo dos anos não foi realizado, mas são apontadas suas principais características. Destacam-se:

- A região de Alexandre Gusmão e Brazlândia,

- As áreas de Tabatinga, Rio Preto, PAD-DF,

- O Jardim Botânico,

- A Fazenda Sucupira e os projetos Combinados Agro urbanos,

- A área próxima ao Tororó,

- Expansões urbanas recentes.

\section{A região de Alexandre Gusmão e Brazlândia}

Apresenta um histórico de vocação agrícola acrescido de projetos governamentais. Mesmo com o desmembramento de boa parte da Colônia Agrícola Alexandre Gusmão em glebas menores, de 2 hectares, a produção agrícola ainda é forte na região. Além das áreas cultivadas (agricultura familiar e hortifrutigranjeiros) há um uso diversificado com chácaras de lazer, e núcleos urbanos isolados. 
Uma maior distância do Plano Piloto e dos principais fluxos, ocasionando certo isolamento da região, ajudou a manter a vocação rural e amenizar as pressões de expansão urbana.

Porém, segundo a CODEPLAN, devido às condições de polo atrativo, território reduzido e expansionismo urbano no DF, o valor da terra alcança patamares exagerados, a restringir sua utilização com atividades de baixa capacidade de retorno, do ponto de vista estritamente financeiro (CODEPLAN, 2015). Neste sentido, a permanência das atividades agrícolas deve-se à rentabilidade das mesmas.

Outra questão a ser observada na região de Brazlândia e Alexandre Gusmão é a relação da fragilidade ambiental da região com o uso de práticas agrícolas intensivas:

O uso intensivo das terras para práticas agrícolas tem desencadeado impactos ambientais significativos, entre eles, o assoreamento e a redução das vazões dos cursos d'água que abastecem a represa do Descoberto, o que poderá comprometer o abastecimento d'água no DF com o passar dos anos. (ZEE, 2009, p. 74)

\section{As áreas de Tabatinga, Rio Preto, PAD-DF}

Estas e demais áreas, inseridas nas zonas rurais de São Sebastião, Planaltina e Paranoá, são representantes do cultivo de grandes culturas no DF. Os nucleamentos urbanos existentes nestas áreas são geridos pelas atividades agrícolas desenvolvidas no local. Representam o urbano em função do rural.

Outro ponto a ser considerado neste perfil agrícola é a localização estratégica de Brasília para o setor de insumos. Conforme aponta estudo da CODEPLAN, a área de influência de Brasília, a chamada Região Geoeconômica (RGB) é uma região de fronteira com crescimento acentuado da produção de grãos ${ }^{27}$ e cana-de açúcar. Segundo este estudo, isso abre oportunidades para o Distrito Federal vinculadas ao processamento industrial dessa produção, como a implantação de plantas

\footnotetext{
27 "Deve-se ressaltar, contudo, a preocupação com a excessiva concentração da produção em dois produtos, soja e milho, que já ocupam $81,0 \%$ da área cultivada com grãos no país e $60,0 \%$ do total, considerando todas as culturas, temporárias e permanentes. Tal concentração tem levada à inibição da área dedicada à outros grãos, especialmente os voltados para a alimentação básica da população, como feijão, arroz e trigo, assim como de outros produtos como mandioca e banana, levando ao encarecimento desses produtos no mercado interno e, mesmo, à recorrentes importações para garantir o abastecimento interno." (CODEPLAN, 2013)
} 
agroindustriais de grande porte. Mas, é preciso melhoria na distribuição de energia em toda a região, insumo vital para o setor industrial.

O estudo aponta ainda que:

\begin{abstract}
...essa ampla produção cria as condições para que Brasília emerja como importante centro de distribuição de insumos para a atividade agropecuária, como sementes, fertilizantes e maquinário agrícola, assim como ascenda à condição de polo prestador de serviços especializados, tais como financeiros, de logística, de manutenção etc. Por fim, condicionado à ampliação e modernização da infraestrutura de transportes, possibilitaria o desenvolvimento de Brasília como centro logístico de toda a região, voltado para a comercialização da produção regional, abrindo espaço para um nicho importante no setor financeiro, o de operações com commodities agrícolas no mercado futuro. (CODEPLAN, 2013)
\end{abstract}

\title{
O Jardim Botânico
}

É um representante da proliferação de condomínios junto com Sobradinho. Apesar de não ser uma região com vocações agrícolas, os parcelamentos irregulares, junto com a ocupação urbana de São Sebastião, tornaram inviável a realização da barragem do São Bartolomeu. Sem a barragem, outras alternativas de recursos hídricos tiveram que ser buscadas para suprir as demandas de abastecimento. A expansão urbana de forma descontrolada e desarticulada das políticas públicas causou um prejuízo para todo o DF.

\footnotetext{
Uma gestão territorial dispersiva e aleatória e a perversidade dos processos imobiliários irregulares ou especulativos redesenharam o espaço do DF à revelia de diretrizes, planos e normas, evidenciando que os instrumentos técnicos e normativos, por si só, não são suficientes para dar conta da complexidade do processo de desenvolvimento do seu espaço. (GONZÁLES, 2010, p176)
}

\section{A Fazenda Sucupira e os projetos Combinados Agro urbanos}

A Fazenda Sucupira e os projetos Combinados Agro urbanos (CAUB I e II) no Riacho Fundo, ilustram intervenções estatais em áreas rurais próximas a núcleos urbanos. As pressões por oferta de moradia urbana acabaram por desvirtuar os projetos originais dos CAUB's, induzindo seu parcelamento. Já a fazenda Sucupira, 
sendo de propriedade estatal, se tornou um enclave rural numa região de expansão urbana.

\section{A área próxima ao Tororó}

Extensa área ao sul do Distrito Federal, foi transformada de área rural para urbana no PDOT de 2009. Durante o processo de elaboração do PDOT, sofreu variações em relação à dimensão e zoneamento (Zona Urbana de Uso Controlado, Zona Urbana de Expansão e Qualificação). Apesar das críticas, denunciando processos de especulação e o não cumprimento da função social da terra, não foi mantida como área rural. O caso representa interesses particulares na ação governamental de planejamento e gestão do solo. Direciona também nova vertente de expansão urbana.

\section{Expansões urbanas recentes}

A parcela de crescimento urbano, à margem da legalidade, corresponde a parcelamentos de áreas rurais para fins de uso urbano, implementados por especuladores imobiliários. Envolvem todos os extratos sociais, desconsideram a legislação e há dificuldade de controle por parte do poder público.

A expansão urbana em Planaltina, o Café Sem Troco (Paranoá), a Ponte Alta (Gama), o condomínio Sol Nascente (Ceilândia), e demais condomínios e loteamentos irregulares que surgem a cada dia, são expressões atuais de expansões urbanas à revelia do planejamento governamental. Envolvem situações como:

- Loteamentos urbanos irregulares, desprovidos de infra estrutura, para atender demanda habitacional de população de baixa renda;

- Parcelamento de áreas com fragilidades ambientais com custos sociais e financeiros, tanto para a população local quanto para o Distrito Federal como um todo.

- A especulação imobiliária lucrativa e permissiva: 
A detenção para grilagem é de, no máximo, quatro anos, além de multa. Já a Lei Federal no 9.099/95 determina que, nos crimes em que a pena mínima for igual ou inferior a um ano, o processo pode ser suspenso por período de dois a quatro anos. O parcelamento irregular do solo se enquadra nessa categoria. A suspensão pode ser proposta pelo Ministério Público, com a condição de que o réu não tenha condenações anteriores. A pessoa não fica mais de um mês presa, e esse tempo vale a pena porque ela ganhou milhões vendendo lotes irregulares... (Correio Brasiliense, 30/01/2012)

- Há loteamentos irregulares em áreas públicas e particulares. A titularidade da terra não impediu a irregularidade.

- A busca do atendimento às normas ambientais e urbanísticas ocorre no processo de legalização, posterior à implantação do loteamento.

A desapropriação parcial das terras rurais no período de implantação do Distrito Federal, o processo inconcluso de desapropriação e a indefinição da titularidade das terras particulares, geraram posteriormente uma série de conflitos no processo fundiário de ocupação privada da terra, conforme aponta Carvalho Junior (2007):

$\checkmark \quad$ Terras em processo de usucapião, dependendo de solução judicial;

$\checkmark$ Terras particulares invadidas e parceladas pelo invasor, muitas vezes contando com a falsificação de documentos.

$\checkmark$ Terras desapropriadas, ou seja, terras públicas e parceladas.

$\checkmark$ Terras em fase de desapropriação, ainda dependentes de decisão judicial e de recursos financeiros para se consolidar a desapropriação e posteriormente a regularização;

$\checkmark$ Terras desapropriadas em comum com partes ocupadas de forma irregular. A solução vai depender de acordo entre as partes, o que deverá ser firmado também na esfera do judiciário. (Carvalho Junior, 2007, p.75)

Apesar da proibição de alienação de terras Estatais a particulares, o processo inconcluso de desapropriação das terras rurais favoreceu a atuação de loteadores e especuladores. As ocupações definidas como solução para moradia de baixa renda ficaram comumente denominadas de invasões, já a opção para média e alta renda foram denominadas de condomínios. Nestes loteamentos se observa falta de implantação de infraestrutura, que deveria ser disponibilizada pelos empreendedores dos loteamentos. Há também litígio entre particulares e a TERRACAP sobre a posse da terra e, questões de ordem ambiental. 
Por fim, observa-se ainda que no processo de planejamento do Distrito Federal há uma segregação espacial desencadeada pelos planos e ações governamentais, com base nas questões ambientais (localização das bacias, anel sanitário) e na preservação do plano urbanístico. O recurso hídrico passou a ser elemento definidor da ocupação espacial. (IPEA, 2002, p.47)

A localização do Parque Nacional de Brasília, do Jardim Botânico, da Reserva Ecológica do IBGE e da APA do São Bartolomeu, apesar da necessidade de preservação dos recursos naturais desses sítios, atuam como barreiras a expansão urbana e ao mesmo tempo sofrendo pressão desta:

Se por um lado, essas áreas de preservação garantem qualidade de vida à população, por outro, pressionam os valores imobiliários, ao restringir possíveis ofertas. Apresentam-se, concomitantemente, como áreas passíveis de serem invadidas para atender a demandas habitacionais reprimidas, por estarem situadas próximas ao aglomerado urbano consolidado. (IPEA, 2002, p.59)

Considerando as configurações atuais, os parágrafos que se seguem, retomam assuntos abordados na revisão da literatura relacionando-os com a pesquisa desenvolvida nas áreas rurais do Distrito Federal.

A proposta de Nakano (2004), da demarcação da Zona de Expansão Urbana no Zoneamento já se encontra nos Planos Diretores do DF. Empregando termos como 'dinamização urbana', 'expansão e qualificação', 'zona de expansão urbana', estas áreas são delimitadas indicando prováveis ampliações das áreas urbanas. Porém, o emprego destes termos, corroborando com o que afirma Nakano, acaba induzindo à especulação imobiliária e o surgimento de outras ocupações. Outro ponto sugerido pelo autor - a realização do Zoneamento Ecológico Econômico - ainda está em processo no DF. Os estudos relativos ao ZEE estão ficando defasados devido ao atraso na sua regulamentação (o material elaborado é de 2009).

As dificuldades para envolver áreas rurais nos Planos Diretores, enfrentadas em pequenos municípios conforme aponta Passos (2010), não correspondem à realidade do DF, onde o Plano Diretor de Ordenamento Territorial (PDOT) é pensado 
para o município como um todo. Neste caso as dificuldades envolvem a falta de articulação e/ou integração entre os órgãos de governo. No tocante à gestão ambiental, existem importantes unidades de conservação relacionadas ao SNUC (Sistema Nacional de Unidades de Conservação), como é o caso das várias APAS (Área de Proteção Ambiental) presentes no DF. Porém, não há articulação das mesmas com a delimitação da Reserva da Biosfera do Cerrado no DF.

As diversas abordagens sobre as áreas rurais e de transição, descritas na revisão da literatura, encontram ressonância na realidade do DF. O quadro de caracterizações de enfoques sobre o rural, apresentado por Campos e Krahl (2006), pode ser validado segundo:

- O enfoque de sociabilidade, apresentado por Carneiro, é observado em comunidades tradicionais como a de Vargem Bonita.

- O Capital Social, com a valorização das redes, pode ser visualizado por meio das associações de produtores de Brazlândia e Alexandre Gusmão.

- O Continuum, propalado por Graziano, tem representantes característicos no $P A D-D F$ e demais áreas de produção de grandes culturas.

A tendência a separação entre espaços de residência, consumo e trabalho em decorrência da dispersão urbana, apontados por Limonad (2010), se relacionam com o DF da seguinte forma:

- Condomínios fechados para classe média e alta próximos a vias de tráfego e em áreas rurais com amenidades ou vocação turística: Jardim Botânico.

- Loteamentos residenciais em áreas rurais para trabalhadores urbanos nas áreas da franja metropolitana: Sobradinho, Ceilandia.

- Dispersão espacial de trabalhadores com a multiplicação de núcleosdormitórios e proliferação de favelas, próximo a grandes eixos viários, em áreas economicamente dinâmicas: o próprio histórico de conformação espacial do DF.

As tendências apontadas por Sposito (2010) se articulam diretamente com a realidade vivenciada:

- Aumento do estoque de terras loteadas como urbanas, não ocupadas, já que a expansão territorial é maior que o crescimento demográfico; 
- Aumento dos preços dos imóveis, tanto porque a expansão territorial em descontínuo valoriza os imóveis, que estão relativamente mais próximos das áreas melhor equipadas das cidades, quanto pelo fato de que os novos imóveis agregam novos produtos e se tornam comparativamente "melhores";

- Imóveis de médio e alto padrão tendem a ser vendidos para pessoas que já eram proprietárias de imóveis, em função dessa diferença de "qualidade" oferecida e não mais, como ocorria anteriormente, quando eram adquiridos por quem não era proprietário ainda;

- ampliação do contingente de pessoas que estão fora das possibilidades de solucionar o problema habitacional no âmbito do mercado.

Na sequência de abordagens, a valorização de atividades não agrícolas apontada por Medeiros (2011) é observada nas atividades de Lazer, moradia e serviços, bem como os nichos de mercado como as produções agroecológicas. O Lago Oeste ilustra bem essa abordagem.

Em relação à expansão urbana sobre o rural, considerando a periodização elaborada por Miranda (2009):

- Da década de 1940 à década de 1960, a urbanização brasileira expandia-se por meio de loteamentos na periferia das capitais, impulsionados pela implantação das Rodovias da integração nacional. A própria criação de Brasília e as Rodovias fazem parte desse momento da história nacional.

- Da década de 1970 aos anos 1990 Intenso êxodo rural e crescente metropolização das principais capitais. No processo de transformações de rural em urbano, a expansão residencial na periferia conforma áreas populares e de status.

- Da década de 1990 ao período recente (Os impactos da urbanização sobre o meio rural geram mais tensões e oportunidades e consequentes interpretações) - A gama de situações encontradas nas áreas rurais do DF ilustram bem essa diversidade.

A gama de situações dos espaços rurais do DF não fecha numa definição. Mas, como afirma Limonad: 
Harvey (2005) aponta que o poder de organizar o espaço se origina em um conjunto complexo de forças mobilizado por diversos agentes sociais: situação exemplificada nas regularizações dos loteamentos irregulares.

No direito à cidade, Lefebvre (2008) fala de um direito à vida urbana, onde o urbano é o lugar do encontro, prioridade do valor de uso sobre o valor de troca. A busca de uma sociedade urbana compreende busca de qualidade de vida, de serviços, de cultura, etc., independentemente de ser área urbana ou rural.

O incremento demográfico, oriundo do aumento das migrações pra o DF, está relacionado à população migrante oriunda do êxodo rural. A questão fundiária sempre esteve presente. A atuação governamental prioriza interesses econômicos em detrimento da maioria da população.

Conforme apontou Maricato (2011), a questão da terra continua a se situar no centro do conflito social. Segue alimentando a desigualdade e a tradicional relação entre propriedade, poder político e poder econômico.

Agudizando os conflitos fundiários sobressai também a questão ambiental. Retomando os estudos da UNESCO (2002) e Tesa e Baptista (2015), o material produzido aqui corrobora com a discussão sobre a tendência à diminuição das paisagens naturais. $\mathrm{Na}$ análise das variáveis até a década de 2000, há uma consolidação da atividade agrícola de alta produtividade e contínua ampliação de núcleos urbanos em detrimento da ampliação de áreas degradadas.

\subsection{Conjecturas futuras}

Considerando o material elaborado na Tese, esse item aborda tendências para as áreas rurais do DF e levanta proposições. Nos recortes por décadas, os elementos de análise proporcionavam diferentes abordagens para enriquecer o estudo. Aqui, as conjecturas futuras serão elaboradas para cada elemento de análise. Os quadros sínteses, reelaborados à partir dos aspectos de análise, servirão de ponto de partida 
para a discussão e elaboração de cenários futuros. Pretende-se, ao final, fazer a ligação destes aspectos e como eles se inter-relacionam.

\section{Aspectos Econômicos}

Quadro 9: Síntese dos Aspectos econômicos ao longo das décadas

\begin{tabular}{|c|c|c|}
\hline $\begin{array}{l}\text { Antecedentes e década de } \\
1960\end{array}$ & e 1980 & $\begin{array}{l}\text { das de } 1990 \\
{ }_{0}\end{array}$ \\
\hline $\begin{array}{l}\text { - Loteamentos rurais de produção } \\
\text { agrícola para abastecimento da } \\
\text { Capital; } \\
\text { - Sistema de posse sem } \\
\text { propriedade-concessão de uso; } \\
\text { - "Granjas-Modelo"; } \\
\text { - Áreas rurais do período } \\
\text { (Pébayle): } \\
\text { 7.Núcleos rurais dos roceiros, } \\
\text { 8.Núcleos rurais de } \\
\text { agricultores e de criadores } \\
\text { de gado, de Vargem } \\
\text { 9.Horticultores de } \\
\text { Bonita e Taguatinga, } \\
\text { 10.Núcleos rurais dos } \\
\text { "citadinos-chacareiros", } \\
\text { 11.Mutações das fazendas } \\
\text { tradicionais de criação de } \\
\text { gado, } \\
\text { 12.Os pequenos invasores } \\
\text { rurais. }\end{array}$ & $\begin{array}{l}1971 \text { - Plano Agropecuário } \\
\text { do Distrito Federal; } \\
1972 \text { - Empresa Brasileira } \\
\text { de Pesquisa Agropecuária } \\
\text { (EMBRAPA); } \\
\text { - } 1972 \text { - Florestamento e } \\
\text { Reflorestamento S/A } \\
\text { (PROFLORA); } \\
\text { - Instituto Nacional de } \\
\text { Colonização e Reforma } \\
\text { Agrária } \\
\text { (INCRA) - Colônia Agrícola } \\
\text { Alexandre Gusmão; } \\
\text { - } 1977 \text { - Programa de } \\
\text { Assentamento Dirigido do } \\
\text { Distrito Federal (PAD-DF) - } \\
\text { agricultura empresarial, } \\
\text { mecanizada, mercado } \\
\text { externo; } \\
\text { 1980/83 - Programa de } \\
\text { estradas vicinais. }\end{array}$ & $\begin{array}{l}\text { - } 1995 \text { - Prove - } \\
\text { fortalecimento } \\
\text { de } \\
\text { microempresas; } \\
1999 \text { - Plano de } \\
\text { Desenvolvimento } \\
\text { Rural do Distrito } \\
\text { Federal - PRÓ- } \\
\text { RURAL; } \\
\text { - predominância } \\
\text { de Brazlândia na } \\
\text { produção de } \\
\text { hortaliças e a } \\
\text { vocação agrícola } \\
\text { no leste do } \\
\text { território; } \\
\text { - Pivôs de irrigação } \\
\text { - Bacia do Rio } \\
\text { Preto; } \\
\text { alta } \\
\text { produtividade e } \\
\text { incremento } \\
\text { tecnológico. }\end{array}$ \\
\hline
\end{tabular}

Como já foi abordado, as áreas agrícolas do Distrito Federal caracterizam-se por uma produção empresarial mecanizada com tecnologia agregada. O elevado preço da terra no Distrito Federal não dá margem a atividades produtivas que não sejam rentáveis.

Nichos de mercado como produtos orgânicos, flores e morangos (Brazlândia) se estabeleceram no quadro agrícola do DF e tendem a uma continuidade futura. 0 
mapeamento de novos nichos, bem como políticas de incentivo e divulgação reforçarão o desenvolvimento dessas atividades.

Outras vocações econômicas para as áreas rurais do Distrito Federal envolvem atividades diversificadas como turismo rural.

No leste do território a produção agrícola com alta produtividades e grandes culturas é uma realidade que se consolidou e indica continuidade futura. Porém, como já foi abordado, as limitações de água na região trazem restrições à expansão e intensificação da produção.

A criação do PADF na década de 1970, é um exemplo de que é possível implementar políticas direcionadas de produção agrícola. Porém, necessitam ser políticas públicas com o peso da implementação de leis. Programas de governo, como ocorreu com PROVE, não possuem garantia de continuidade com a mudança do poder executivo.

Situações como a Vargem Bonita, onde há proximidade do mercado consumidor e acompanhamento técnico governamental podem ser viabilizadas, por meio de políticas públicas, em locais estratégicos, próximos dos centros consumidores. Uma proposição neste sentido é a implementação de políticas públicas para produção agroecológicas de hortifrúti, visando o abastecimento de áreas urbanas próximas e a proteção ambiental. Para não repetir as distorções que ocorreram na implantação da Capital, é necessário: implementar leis específicas, delimitação exata das áreas produtivas e cadastramento dos produtores, acompanhamento constante governamental, incentivo à produção por meio de subsídios financeiros e políticas de comercialização, especificação detalhada das atividades produtivas de abastecimento (hortifrúti), adequação com o meio ambiente - em relação ao uso de recursos hídricos, técnicas produtivas e evitar uso de fertilizantes e agrotóxicos. 


\section{Aspectos Ambientais}

Quadro 10: Síntese dos Aspectos Ambientais ao longo das décadas

\begin{tabular}{|c|c|c|}
\hline $\begin{array}{l}\text { Antecedentes e década de } \\
1960\end{array}$ & Décadas de 1970 e 1980 & Décadas de 1990 e 2000 \\
\hline $\begin{array}{l}\text { Relatórios Cruls e Belcher: } \\
\text { - Importantes estudos } \\
\text { - } \text { ambientais } \\
\text { - } \text { pouca umidade, } \\
\text { suscetibilidade do solo a } \\
\text { - cuidado com os recursos } \\
\text { hídricos - rios pouco } \\
\text { caudalosos. } \\
1961 \text { - Parque Nacional de } \\
\text { Brasília - proteção } \\
\text { manancial Santa Maria; }\end{array}$ & $\begin{array}{l}\text { Déc 1970: } \\
\text { - Desconsideração de } \\
\text { fatores ambientais em } \\
\text { projetos urbanísticos; } \\
\text { - PLANIDRO - segregador } \\
\text { espacial; } \\
\text { Déc 1980: } \\
\text { - APAs - objetivo é } \\
\text { compatibilizar a } \\
\text { conservação da natureza } \\
\text { com o uso de parcela de } \\
\text { seus recursos naturais. } \\
\text { - Regulamentação do } \\
\text { EIA/RIMA }\end{array}$ & $\begin{array}{l}\text { - } 1996 \text { rezoneamento da } \\
\text { APA do São } \\
\text { Bartolomeu- } \\
\text { viabilizando } \\
\text { condomínios, } \\
\text { inviabilizando } \\
\text { barragem; } \\
1994 \text { - Reserva da } \\
\text { Biosfera do Cerrado do } \\
\text { Distrito Federal; } \\
\text { Floresta Nacional de } \\
\text { Brasília - FLONA; } \\
\text { Intensidade de } \\
\text { ocupação rural x áreas } \\
\text { degradadas. }\end{array}$ \\
\hline
\end{tabular}

Os relatórios dos estudos para implementação da Capital já alertavam sobre a suscetibilidade do solo a processos erosivos e os recursos hídricos pouco caudalosos. As extremidades noroeste e sudoeste do Distrito Federal e a área central (ao longo da bacia do São Bartolomeu) apresentam limitações naturais (de relevo e fragilidades ambientais) à ocupação agrícola e urbana.

Ao longo dos anos, o uso do discurso ambiental foi empregado para justificar processo de segregação espacial na ocupação urbana. O PLANIDRO foi utilizado para barrar a expansão urbana próximo ao Plano Piloto. Porém, atualmente observa-se um adensamento urbano e verticalização entre as áreas do Guará/SCIA. O tombamento do 
Plano Piloto e a pressão do mercado imobiliário indicam uma intensificação da ocupação das áreas ao redor e sua verticalização.

Outras áreas ambientalmente frágeis tiveram atenções diferenciadas em relação às áreas próximas ao Plano Piloto. Não houve o controle intensivo da expansão urbana em áreas como Vicente Pires, Arniqueiras e Jardim Botânico ${ }^{28}$ - áreas originalmente rurais, com fragilidades ambientais. Embora estejam consolidadas como áreas urbanas, sugere-se delimitar sua ocupação por meio de: lotes unifamiliares, parcelas maiores, sem verticalização, sem impermeabilização do solo, desconstituir lotes em áreas frágeis, rever o traçado das vias - originalmente rurais e, inserir parques nas áreas de proteção ambiental.

Porém, a preocupação com a proteção ambiental ocorre desde a implementação da Capital - a criação do parque Nacional foi em 1961. Essa preocupação é oficializada por meio da implementação da legislação ambiental. Sua especificação, como a delimitação de unidades de conservação, foi insuficiente para conter a degradação ambiental oriunda dos avanços de atividades agrícolas e a expansão urbana. Mas, é importante salientar que, sem essa legislação, os estragos ambientais seriam maiores.

Apenas o aparato legal é insuficiente para conter os avanços urbanos nas áreas ambientalmente frágeis. Tornam-se necessárias políticas públicas que venham a inserir a população ao redor dessas áreas, principalmente em áreas de expansão urbana.

Uma proposta é estipular áreas com necessidade de preservação ambiental como nascentes e rios - como áreas de futuros parques nos processos de expansão urbana. Definir uma faixa de afastamento (além dos limites da APP) para a área utilizável do parque. Os loteamentos futuros devem prever a inserção do parque.

A não finalização do Zoneamento Ecológico Econômico dificultou o controle dos processos de degradação ambiental nas áreas de produção agrícola. A tendência é

\footnotetext{
${ }^{28}$ Neste caso ainda houve a inviabilização da barragem, gerando prejuízo no abastecimento de água do Distrito Federal.
} 
aumentar essa degradação. A implementação do ZEE e políticas públicas ambientais, como o 'produtor de água' da CAESB, poderão minimizar essa degradação.

\section{Aspectos Sociais}

Quadro 11: Síntese dos Aspectos Sociais ao longo das décadas

\begin{tabular}{|c|c|c|}
\hline $\begin{array}{l}\text { Antecedentes e } \\
\text { década de } 1960\end{array}$ & $\begin{array}{l}\text { Décadas de } 1970 \text { e } \\
1980\end{array}$ & Décadas de 1990 e 2000 \\
\hline $\begin{array}{lr}\text { - } & \text { Migração para } \\
\text { construção } & \text { da } \\
\text { Capital; } & \\
\text { - } & \text { Braslândia } \\
\text { Paranoá - } & \text { pré- } \\
\text { existentes; } \\
\text { - } \text { Cidades Satélites } \\
\text { projetadas - } \\
\text { Gama, Sobradinho } \\
\text { e Taguatinga; } \\
\text { Nucleamentos - } \\
\text { Cidade Livre, } \\
\text { Candangolandia e } \\
\text { Vila Paranoá; }\end{array}$ & $\begin{array}{l}\text { - Erradicação de invasões } \\
\text { e crescimento das } \\
\text { cidades satélites; } \\
\text { - Expansão urbana sobre } \\
\text { o rural no entorno; } \\
\text { - } 1983 \text { GEPAFI - Grupo } \\
\text { Executivo para } \\
\text { assentamento de } \\
\text { favelas e invasões; } \\
\text { - } 1986 \text { combinado } \\
\text { agrourbano; } \\
\text { - } 1989 \text { regularizadas: } \\
\text { Paranoá, Núcleo } \\
\text { Bandeirante, Ceilândia, } \\
\text { Guará e Samambaia; } \\
\text { - Classe média - } \\
\text { condomínios; }\end{array}$ & $\begin{array}{l}\text { - Oficializados década de } 1990 \text { - Santa } \\
\text { Maria, São Sebastião, Recanto das } \\
\text { Emas, Riacho Fundo } \\
\text { Candangolândia } \\
\text { - Maior número de invasões } \\
\text { habitacionais - Paranoá e São } \\
\text { Sebastião (fixação de invasões): } \\
\text { - Estado criando assentamentos sem } \\
\text { tratar o problema habitacional na } \\
\text { dimensão requerida - Sobradinho II } \\
\text { (política desapropriação de áreas } \\
\text { rurais) } \\
\text { - Processo de conurbação urbana com } \\
\text { ocupação ao longo dos eixos viários; } \\
\text { - Oficializados década de } 2000 \text { - Águas } \\
\text { Claras, Riacho Fundo II, Varjão, } \\
\text { ParkWay, SCIA, Sobradinho II, Jardim } \\
\text { Botânico, Itapoã e SIA e, Vicente } \\
\text { Pires. } \\
\text { - Brasília metrópole }\end{array}$ \\
\hline
\end{tabular}

O controle estatal no planejamento e contenção da ocupação urbana no DF levou à expansão urbana sobre áreas rurais no entorno. A tendência é continuar essa expansão devido ao preço da terra no DF. 
Ao observar o processo histórico, há mais loteamentos urbanos criados via Estado do que espontâneos. É fato que, devido à elevada demanda habitacional tornase necessária a intervenção governamental. Porém, as políticas foram no sentido de dar lotes unifamiliares. O processo de expansão urbana horizontal acarreta custos na infraestrutura e no deslocamento - devido às grandes distancias trabalho-moradia. Os nucleamentos urbanos necessitam ser pensados em relação ao seu adensamento, ao contrário do espraiamento em direção às áreas rurais.

As áreas rurais nas proximidades dos locais de conurbação urbana sofrerão acentuada pressão para sua urbanização, principalmente ao longo dos eixos viários. Políticas públicas de incentivo à produção e controle das áreas ambientais poderão minimizar este processo.

\section{Aspectos Espaciais}

Quadro 12: Síntese dos Aspectos Espaciais ao longo das décadas

\begin{tabular}{|c|c|c|}
\hline $\begin{array}{l}\text { Antecedentes } \\
\text { década de } 1960\end{array}$ & écadas de 1970 e 1980 & $\begin{array}{l}\text { Décadas de } 1990 \text { e } \\
2000\end{array}$ \\
\hline $\begin{array}{l}\text { - Especulação na área } \\
\text { da futura capital; } \\
\text { - Desapropriação } \\
\text { inconclusa } \\
\text { dificuldade de mapear } \\
\text { fazendas; } \\
\text { - Áreas rurais definidas } \\
\text { fora da área } \\
\text { metropolitana } \\
\text { delimitada pela EPCT. }\end{array}$ & $\begin{array}{l}\text { - } 1974 \text { PERGEB - Programa Especial } \\
\text { para a Região Geoeconômica de } \\
\text { Brasília. } \\
\text { - } 1977 \text { PEOT - Plano Estrutural de } \\
\text { Organização Territorial do DF - } \\
\text { direcionar as áreas de expansão } \\
\text { urbana; } 1985 \text { POT - Plano de Ocupação } \\
\text { - Territorial do DF - } \\
\text { macrozoneamento do território; } \\
\text { - 1986/1990 - POUSO - Plano de } \\
\text { Ocupação e Uso do Solo }\end{array}$ & $\begin{array}{l}\text { - Atuação da Câmara } \\
\text { legislativa; } \\
\text { - Variações na natureza } \\
\text { jurídica das terras; } \\
\text { - PDOT 1992 - } \\
\text { Macrozoneamento; } \\
\text { - PDOT 1997-delimitações } \\
\text { para as áreas rurais e } \\
\text { ambientais; } \\
\text { - PDOT 2009 - Duas } \\
\text { definições para áreas } \\
\text { rurais; }\end{array}$ \\
\hline
\end{tabular}

O processo de Planejamento espacial no Distrito Federal direciona-se para a adequação à tendências de ocupação do solo e de interesses específicos em detrimento do planejamento para o futuro. A desapropriação inconclusa e as variações 
na natureza jurídica das terras, ao contrário da pretensão inicial, dificultam o controle e planejamento de uso e ocupação pelos órgãos de planejamento.

Proposição para trabalhar as áreas de expansão urbanas:

Adaptação de instrumentos do Estatuto das Cidades como:

- Direito de Preempção - com o Estado tendo prioridade na compra e controlando o valor da terra;

- Outorga Onerosa de Alteração de Uso - De rural para urbano.

Políticas direcionadas às áreas periurbanas como:

- Elaboração de leis específicas para a área;

- Delimitação de uma zona de expansão urbana estabelecendo uma faixa (distância do perímetro urbano);

- Definição de usos rurais específicos enquanto estiver na transição;

- Liberar sua ocupação urbana somente após esgotar as possibilidades dos vazios urbanos;

- Preço da terra definido pelo governo.

A figura 56 busca ilustrar tendências na ocupação do solo das áreas rurais do DF, numa tentativa de síntese das variáveis:

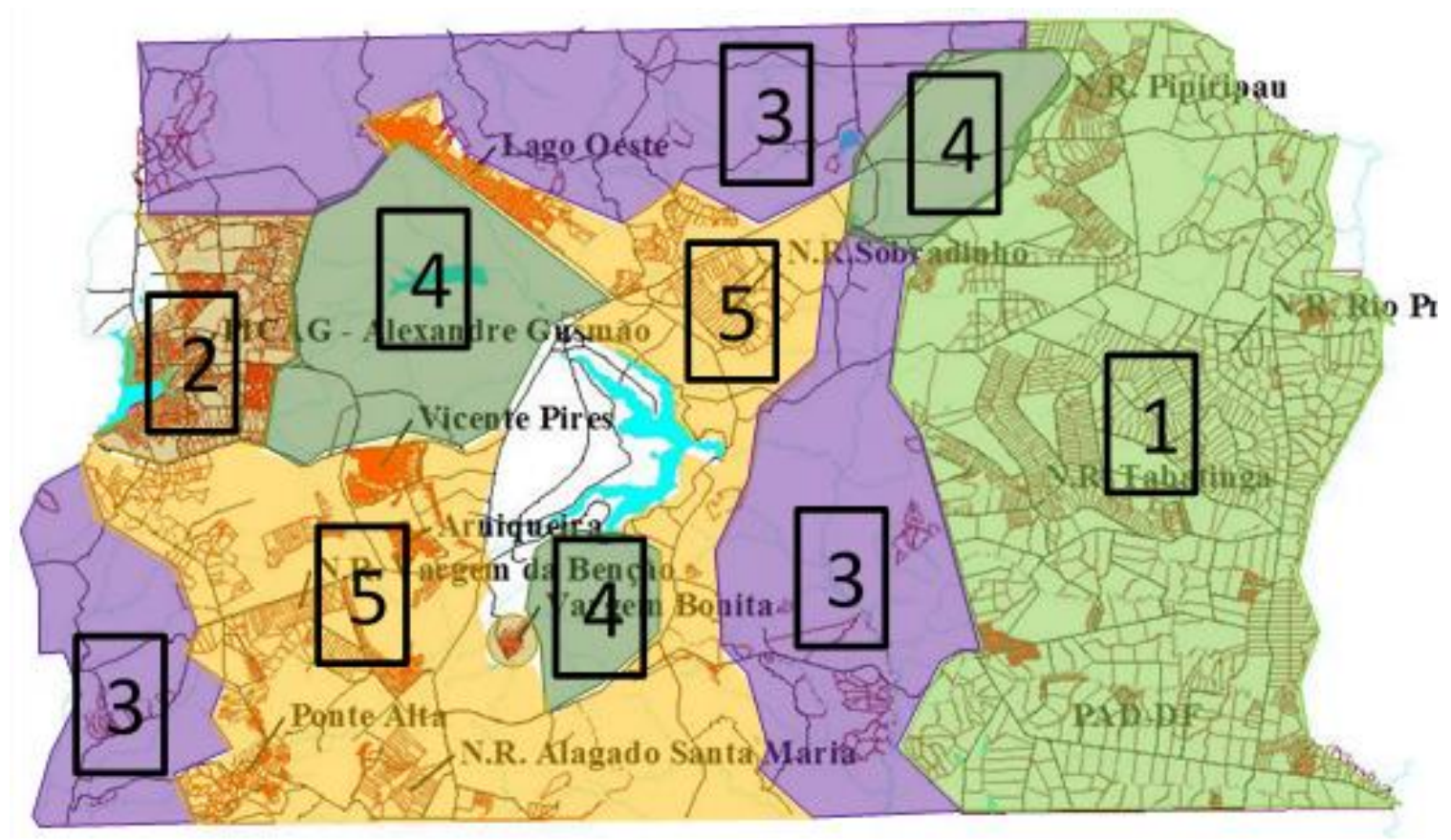


1 - Áreas de predominância agrícola com agricultura intensiva e mecanizada, predominando grandes plantios. Enfrentando problemas de expansão futura devido à escassez hídrica.

2 - Áreas de predominância agrícola com agricultura intensiva e mecanizada, prevalecendo pequenas parcelas. Predominando hortifrúti e nichos de mercado. Enfrentando problemas futuros com a fragilidade do solo.

3 - Áreas que apresentam fragilidade ambiental e restrição física (topografia) à ocupação urbana e rural. Apresentam potencialidades para o turismo rural. São limitadores nos processo de expansão urbana e rural.

4 - Áreas de proteção integral. Limitadoras de uso e ocupação do solo urbano e rural.

5 - Regiões onde as áreas rurais sofrem pressão dos processos de expansão urbana. O uso rural é diversificado, havendo chácaras de lazer, produção de hortifrúti, beneficiamento da produção, turismo rural. Há uma tendência de se transformarem em urbanas ou acentuarem sua vocação em função das áreas urbanas próximas. 


\section{CONSIDERAÇÕES FINAIS}

Para onde vai o rural no DF? Na pergunta do título houve uma intenção de instigar as principais questões que esta tese se propôs a analisar:

Qual o perfil das áreas rurais do DF? Há variações ao longo dos anos? Como e por quê?

Inicialmente é preciso considerar que não há um único perfil para as áreas rurais do Distrito Federal e que nunca houve, desde o período de implantação; ocorrendo ainda, variações ao longo dos anos.

A pretensão inicial para as áreas agrícolas, de suprir o abastecimento da nova capital, funcionou em partes. Havia usos em paralelo, como o de subsistência e outros usos foram sendo forjados, como as chácaras de veraneio. Com o decorrer das décadas novos usos foram surgindo como o turismo rural em Sobradinho e Brazlândia. Vocações foram se firmando em algumas regiões, como a produção de hortifrúti em Brazlândia e Vargem Bonita.

$>$ Qual o papel do planejamento 'espacial' nas áreas rurais do DF? Indução/retenção do crescimento urbano? Controle ambiental? Desenvolvimento agrícola?

A implementação de assistência técnica por meio da Embrapa e Emater e linhas de financiamento trouxeram maior profissionalização à produção rural. A implementação do PADF na década de 1970 enfatizando a produção de grãos no Paranoá trouxe um perfil agroexportador para essa região, bem distante da pretensão de abastecimento interno. Estas variações são impulsionadas em grande parte por interesses financeiros e demandas de mercado. O caso do PADF enfatiza o direcionamento político governamental para o DF.

Quanto ao papel do planejamento espacial para as áreas rurais há uma estreita relação com interesses socioeconômicos por meio de direcionamentos 
políticos. O Planidro na década de 1970 atuou na retenção do crescimento urbano e controle ambiental. O PDOT de 2009 altera os usos da área rural do Tororó por meio da destinação de 'zona urbana de expansão e qualificação', induzindo o crescimento urbano.

Com os processos de expansão urbana e especulação imobiliária, as áreas rurais no DF serão todas urbanas?

É fato que as zonas rurais numa região metropolitana sofrem a pressão pelo aumento do valor da terra, impulsionada pela especulação imobiliária. Somando a esta questão têm se as demandas habitacionais e de equipamentos urbanos. Pode-se observar que estes fatos ocorreram principalmente onde se tentou usar as áreas rurais como tampão para conter o crescimento urbano. Não houve como conter a pressão urbana na área delimitada pela estrada parque contorno (EPCT). Outros fatores, indutores do crescimento urbano, observados na realidade de Brasília, são os eixos de circulação viária. A pressão da expansão urbana ocorre principalmente nas áreas próximas aos perímetros urbanos e, entre os núcleos urbanos no processo de conurbação.

Porém, a partir dos recortes temporais desta pesquisa pode-se inferir que a tendência para as áreas rurais do Distrito Federal não passa por uma generalização de se tornarem todas urbanas. Inicialmente há limitações físicas e ambientais. As áreas de proteção, apesar das pressões de invasões, permanecem protegidas por leis. As barreiras físicas de relevo existentes nas bacias dos rios São Bartolomeu, Descoberto e Maranhão, se não inviabilizam, ao menos dificultam uma maior ocupação urbana.

Em relação à produção agrícola há diferenciação em relação às demais áreas rurais do país. As áreas rurais do DF tem uma ampla cobertura de estradas, energia elétrica, escolas, postos de saúde, assistência técnica e linhas de financiamento. As culturas agrícolas envolvem tecnologias de ponta e alta capacidade de retorno. A elevada produtividade de grãos da região do PADF, a consolidação de vocações agrícolas (morango em Brazlândia, hortifrúti em Vargem Bonita...) e os nichos de mercado agroecológico (fazenda Malunga, assentamentos e pequenos produtores), 
além de enfatizar a dinâmica das zonas rurais, apontam novos rumos no processo de ocupação.

As cidades seguem crescendo, bem como as áreas rurais agrícolas. 0 ponto nevrálgico neste contexto são as áreas com fragilidades ambientais. Estão perdendo espaço físico em detrimento das áreas agrícolas e urbanas. Sua negligencia poderá, num futuro próximo, interferir na própria viabilidade das áreas urbanas e rurais e, na sociedade como um todo.

Portanto, para onde vai o rural no DF? As prospectivas para o futuro indicam as tendências verificadas ao longo da pesquisa.

O rural, de produção agrícola, longe das áreas urbanas, continuará rural apresentando variações de configurações espaciais. Porém terá limitações ambientais à expansão da produção. Os pivôs de irrigação enfrentarão limitações de recursos hídricos num futuro próximo. Além das limitações à ampliação das lavouras, poderá haver diminuição da produção se o uso dos recursos hídricos não forem planejados de forma consciente.

O rural, próximo às áreas urbanas, nos vetores de expansão urbana, será urbano (ou com usos e atividades subordinados ao urbano) e com agravos ambientais. As áreas periurbanas no Distrito Federal, verificadas na análise dos resultados, necessitam urgente de políticas públicas direcionadas. As propostas elaboradas no item de conjecturas futuras apontam direcionamentos para melhorar o quadro de degradação e qualificar sua ocupação espacial.

O rural, ambiente natural delimitado por unidade de conservação determinada por lei, continuará sendo preservado, mesmo sofrendo alguma degradação. Os mecanismos legais de preservação das áreas ambientais auxiliam na contenção da ocupação exacerbada porém há que se buscar outros mecanismos de atuação. Mais do que medidas punitivas ou restritivas, é preciso instigar a participação da população no cuidado com as áreas ambientais.

O rural, ambiente natural, sem a proteção de legislação específica, e próximo à áreas agrícolas poderá vir a ampliar a área de plantio ou se tornar área degradada, 
necessitando de recuperação. As áreas naturais, como observado na análise das décadas, são as mais afetadas nos processos de ocupação urbana e rural no DF. Ações como mudanças no modelo produtivo empregando agroecologia e técnicas de recuperação do solo e dos recursos naturais necessitam ser priorizadas. Elas precisam ser encaradas, não como alternativas, mas como necessidades para viabilizar a ocupação espacial do DF como um todo. A mudança de paradigmas no uso e ocupação das áreas rurais no DF é uma necessidade para viabilizar sua própria ocupação, tanto urbana quanto rural.

No estudo das sociedades urbanas, apontadas por Lefebvre, outras lacunas necessitam ser estudadas envolvendo os agentes sociais e seus mecanismos de atuação. A atuação de agentes sociais (especuladores, movimentos ambientais, sindicatos, associações de produtores, movimentos de moradia, entre outros) apareceu de forma indireta no trabalho por meio do desenrolar dos fatos históricos. As criações das cidades satélites para atender a demanda habitacional de baixa renda, as diversas áreas ambientais, o surgimento de condomínios irregulares atendendo a demanda reprimida de habitação da classe média, são alguns exemplos de fatos influenciados por atores sociais organizados. Observa-se a necessidade de abordar os conflitos sociais existentes, tanto no processo de crescimento urbano e a necessidade de moradia, quanto como se desenvolve a vida das pessoas de perfil agrícola que vive nestas áreas. Outro ponto importante para estudos futuros é a atuação dos agentes sociais envolvidos nas transformações das áreas rurais. O material elaborado na pesquisa poderá subsidiar o aprofundamento nestas questões em estudos futuros, com o detalhamento de elementos motivadores e formas de atuação.

Espera-se que o material produzido neste trabalho - referente à transformações sócio espaciais ocorridas nas áreas rurais do DF ao longo do tempo contribua com o entendimento dos processos de uso e ocupação rural, expansão urbana, e degradação ambiental. E principalmente - para que as tendências observadas não se tornem realidade - que as informações produzidas aqui, venham auxiliar em novos processos de ocupação do território do Distrito Federal, equilibrando ocupação urbana, produção agrícola e preservação ambiental. 
ALENTEJANO, P. Estrutura Fundiária. In CALDART, R. S. (Org.) Dicionário da Educação do Campo. São Paulo. Expressão Popular. 2012.

ALLEN, A. Experiências internacionais de articulação entre o planejamento ambiental e a interface rural-urbana. In STEINBERG (ORG), Território, ambiente e políticas públicas espaciais. Brasília: LGE editora. 2006.

ALIER, J. M. Da Economia Ecológica ao Ecologismo Popular. Blumenau: Editora da FURB, 1998.

ALVES, J.C.L. Ocupação urbana e impactos ambientais: Vicente Pires - o reverso da ocupação irregular em Brasilia/DF. Dissertação de Mestrado, Anápolis: Uni evangélica. 2011.

ARAÚJO, M.F.S. São Sebastião - Do sonho à cidade real. Dissertação de Mestrado, Brasília: FAU/UNB. 2009.

ARQUIVO PÚBLICO DO DISTRITO FEDERAL. Brasília fatos importantes dos antecedentes até 21 de abril de 2010. GDF, Secretaria de Cultura.

ASCELRAD, H. Eixos de articulação territorial e sustentabilidade do desenvolvimento do Brasil. Rio de Janeiro, Projeto Brasil sustentável e democrático: Fase, 2001.

BARBO, L.C. Preexistências de Brasilia. Reconstruir o território para construir a memória. Dissertação de mestrado. Dissertação de Mestrado, Brasília: FAU/UNB. (2010).

BERNARDELLI, M.L.F.H. Contribuição ao debate sobre o urbano e o rural In: SPOSITO, M.E.B. \& WHITACKER, A.M. (org.) Cidade e Campo - relações e contradições entre urbano e rural. São Paulo, Editora Expressão Popular, 2a Ed. 2010.

BERTOLINI, V.A. Ocupando o Cerrado - avaliação do processo de implantação de assentamentos rurais no entorno do Distrito Federal. Dissertação de Mestrado, Brasília: FAU/UNB. (2005). 
BERTRAN, P. História da terra e do homem no Planalto Central: eco-história do Distrito Federal. Do indígena ao colonizador. Disponível em: http://www.pirenopolis.tur.br/arquivo/historia_da_terra.pdf (acesso em: 20/10/2015)

BICCA, B., BICCA, P. Org. Arquitetura na Formação do Brasil, 2008. Brasília: UNESCO, IPHAN, 2a Ed. 2008.

BRASIL, GEO Brasil: recursos hídricos: resumo executivo. Brasília: Ministério das Cidades, Brasília: MMA; ANA, 2007.

Estatuto da Cidade - Guia para Implementação pelos Municípios eCidadãos. Brasília: Câmara dos Deputados, 2001. Plano Diretor participativo - Guia para a elaboração pelos Municípios e Cidadãos. Brasília: Ministério das Cidades, 2001. Constituição (1988). Constituição da República Federativa do Brasil, 1988. Brasília: Senado Federal, Centro Gráfico, 1988.

BRITO, J.D. De Plano Piloto a metrópole: a mancha urbana de Brasília. Tese. FAU/UNB, 2009.

BÄCHTOLD, F. População de cidades do entorno de Brasilia cresce $29 \%$. Folha.com - $\quad$ Cotidiano. 13/12/2010. Disponivel em: http://www1.folha.uol.com.br/cotidiano/845266-populacao-de-cidades-do-entornode-brasilia-cresce-29.shtml Acesso em 02/02/2011.

CALDART, R. S. (ORG.) Dicionário da Educação do Campo. São Paulo. Expressão Popular. 2012.

CAMPOS, N. KRAHL, M.F.L. Territorialidade: Elo entre o espaço rural e o espaço urbano. In STEINBERG (ORG), Território, ambiente e políticas públicas espaciais. Brasília: LGE editora. 2006.

CARLOS, A.F.A. Seria o Brasil "menos urbano do que se calcula"? In: CARLOS, A.F.A. O espaço urbano: novos escritos sobre a cidade. São Paulo, Contexto, 2004. A condição espacial. Editora Contexto; 2011. 
CARNEIRO, F.F. A Saúde no Campo: das políticas oficiais à experiência do MST e de famílias de "bóias frias" em Unaí, Minas Gerais, 2005. Tese de Doutorado. Belo Horizonte: Escola de Veterinária/UFMG, 2005.

CARVALHO, J.L.H.C. PROVE -"Programa de Verticalização da Pequena Produção Agrícola". http://www.agriculturaurbana.org.br/RAU/AU05/AU5prove.html (acesso em 07/05/2014)

CARVALHO, V. Conterrâneos velhos de guerra. Brasília: Fundação Cultural do DF, 1997.

CARVALHO JUNIOR, W.M, 2007. Os impactos ambientais decorrentes da ocupação urbana: o caso da colônia agrícola Vicente Pires - Dissertação de Mestrado, Brasília: GEA/UNB. 2007.

CIDADES: Revista científica. V.5, n.8, 2008. A urbanização da sociedade. ISSN1679-3625. São Paulo: Ed. Expressão Popular; 2010. V.7, n.11, 2010Formas espaciais e política(s) urbana(s). ISSN1679-3625. São Paulo: Ed. Expressão Popular; 2010.

CODEPLAN. O Relatório Técnico sobre a Nova Capital da República. Relatório Belcher, 4a Edição, GDF/Codeplan, Brasília. 1995 Índice de Desempenho Econômico do Distrito Federal IDECON/DF: 4o Trimestre de 2014. GDF/Codeplan/SEPLAG, Brasília, 2015.

CORREA, R. L. Sobre agentes sociais, escala e produção do espaço: um texto para discussão. In: CARLOS, A. F. A; SOUZA, M.L.; SPOSITO, M.E.B. A produção do espaço urbano. Agentes e processos, escalas e desafios. São Paulo: Contexto, 2011b. p. 41-53.

COSTA, G. G. A Cartografia nos planos diretores do Distrito Federal. Anais do I Simpósio Brasileiro de Cartografia Histórica. Paraty, 2011.

As Regiões Administrativas do Distrito Federal, de 1960 a 2011. Tese Doutorado. FAU/UNB, 2011.

COSTA, L. Relatório do Plano Piloto. Brasília, 1957 
EMATER, conjuntura socioeconômica rural - 2009. Gerência de programação e orçamento - GEPRO. Arquivo eletrônico. 2009.

FERREIRA, I.C.B. PENNA, N.A., Brasília: novos rumos para a periferia. In: PAVIANI, Aldo (org.) Brasília: Moradia e exclusão. Brasília, editora UNB, 1996.

FERREIRA, I.C.B., Gestão do Território e novas territorialidades. In: PAVIANI, Aldo (org.) Brasília - gestão urbana: conflitos e cidadania. Brasília, editora UNB, 1998. - Brasilia: mitos e contradições na história de Brasília. In: PAVIANI, A... [et al.] (Org.), Brasília 50 anos: da capital a metrópole. Brasília: Editora UNB, 2010. Os desafios da urbanização brasileira. In: Lestienne, Bernard, et alli (orgs.). População e pobreza. São Paulo, Ed. Loyola, 2003.

FILHO, F.B.B. As relações rural-urbano no Distrito Federal. Tese de doutorado. Campinas, São Paulo: Unicamp, 2001.

FONSECA, F.O. Olhares Sobre o Lago Paranoá, Brasília: SEMARH, 2001.

FORTES, P.T.F.O.; Barroso,E.W.S.; Silva,M.A.S.; Guedes,C.O.O. Regularização fundiária em imóveis da União no Distrito Federal Parte 1: demarcação de imóveis. Anais XIII Simpósio Brasileiro de Sensoriamento Remoto, Florianópolis, Brasil, 21-26 abril 2007, INPE, p. 5233-5240.

FREITAS, C.F.S. Proteção ambiental e direito à cidade no processo de expansão urbana do Distrito Federal: até que ponto existe um conflito? Tese de doutorado. UNB. Brasília, 2008.

FREITAS, G. Células desconexas - Condomínios fechados e as políticas públicas de regularização do Distrito Federal. Dissertação de Mestrado, Brasília: FAU/UNB. 2013.

FREITAS, T.M. A expansão urbana no Distrito Federal e a dinâmica do mercado imobiliário: o caso do Gama. Dissertação de Mestrado, Brasília: GEA/UNB. 2013.

FURTADO, M.F.R.G. Áreas de interface periurbana: Desafios conceituais $e$ metodológicos. In: RANDOLPG, R., SOUTHERN, B.C. (org.) Expansão metropolitana e 
transformação das interfaces entre cidade, campo e região na América Latina. São Paulo: Max Limonad, 2011.

GOMES, G. A arquitetura do Açúcar. In: BICCA, B., BICCA, P. Org. Arquitetura na Formação do Brasil, 2008. Brasília: UNESCO, IPHAN, 2aㅡ Ed. 2008.

GUIA, G.A., CIDADE, L.C.F., Segregação residencial e reprodução das desigualdades socioespaciais no aglomerado urbano de Brasília. In: Cadernos Metrópole - Trabalho e moradia, v.12, n.23 jan/jun 2010. ISSN 1517-2422. Observatório das Metrópoles. São Paulo: EDUC, 2010.

GONÇALVES, T. D. Recursos Hídricos no Distrito Federal: Modelagem Hidrológica para subsidiar a gestão sustentável na bacia do Ribeirão Pipiripau. Tese Doutorado. UNB, Instituto de Geociencias.148f. 2012.

GONÇALVES, T. D. et al. Sistema de informação geográfica como ferramenta de apoio à outorga dos recursos hídricos subterrâneos no Distrito Federal. Revista Brasileira de Geociências, volume 39 (1):169-180, março de 2009. Arquivo digital disponível on-line no site www.sbgeo.org.br

GONZÁLEZ, S.F.N., A gestão urbanística do espaço habitado: o objeto e o método no caso do Distrito Federal. In: PAVIANI, A... [et al.] (Org.), Brasília 50 anos: da capital a metrópole. Brasília: Editora UNB, 2010.

GOUVÊA, L.A.C., Habitação e emprego: uma política habitacional de interesse social. In: PAVIANI, Aldo (org.) Brasília: Moradia e exclusão. Brasília: editora UNB, 1996.

HARVEY, D. A produção capitalista do espaço. São Paulo, Annablume, 2ạ. Ed. 2005.

IBGE - Instituto Brasileiro de Geografia e Estatística. Disponível em: $<\underline{\text { www.ibge.gov.br> }}$. Acesso em julho de 2009 IBGE - Instituto Brasileiro de Geografia e Estatística.

Disponível

em: http://www.ibge.gov.br/home/presidencia/noticias/noticia visualiza.php?id noticia=1 $\underline{766}$ Acessado em 03/02/2011 
IPEA-Instituto de Pesquisa Econômica Aplicada. Gestão do uso do solo e disfunções do crescimento urbano, Volume 3: instrumentos de planejamento e gestão urbana: Brasília e Rio de Janeiro/ IPEA, USP, UNB, UFRJ. Brasília: IPEA, 2001.

KUBITSCHEK, J. Porque construí Brasília. Brasília: Senado Federal (Coleção Brasil 500 anos). Conselho Editorial. 2000. Disponível em: http://www2.senado.leg.br/bdsf/item/id/1039

LEFEBVRE, H. O Direito à Cidade. São Paulo: Centauro, 2001, 3a reimpressão 2011.

LIMONAD, E. Regiões Reticulares: breves considerações para compreender as novas formas urbanas. In: Revista Cidades, V.7, n.11, 2010. Formas espaciais e política(s) urbana(s). ISSN1679-3625. São Paulo: Ed. Expressão Popular; 2010.

LOJIKINE, J. O Estado Capitalista e a questão urbana. São Paulo: Martins Fontes. 1981.

MALAGUTTI, C.J. Loteamentos Clandestinos no DF: legalização ou exclusão? Dissertação de Mestrado. FAU/UNB, Brasília, 1996.

MANCINI, G.A. Avaliação dos custos da urbanização dispersa no Distrito Federal. Dissertação de Mestrado. FAU/UNB, Brasília, 2008.

MARICATO, E. Brasil, cidades - alternativas para a crise urbana. Rio de Janeiro. Ed. Vozes, 2001.

Dimensões da Tragédia Urbana In: "REVISTA SEM TERRA" - Ano V, no17, out/dez 2002.

O impasse da política urbana no Brasil. Rio de Janeiro. Ed. Vozes, 2011.

MEDEIROS, R.M.V. Dilemas na conceituação do campo e do rural no Brasil. In SAQUET, M.A., SUZUKI, J.C., MARAFON, J.G. (org.) Territorialidades e diversidade nos campos e nas cidades latino-americanas e francesas. São Paulo. Ed. Outras Expressões. 2011. 
MINISTÉRIO DO MEIO AMBIENTE (2003). Zoneamento Ecológico-Econômico da Região Integrada de Desenvolvimento do Distrito Federal e Entorno - Fase I (Volume I).

MIRANDA, L. I. B. A reforma urbana, as políticas territoriais e a questão urbana-rural:uma integração necessária In BITOUN, J., MIRANDA, L. Desenvolvimento e Cidades no Brasil. Contribuições para o debate sobre as políticas territoriais. Recife. FASE: Observatório das Metrópoles. 2009.

. Planejamento em Áreas de Transição Rural-Urbana: Velhas Novidades em Novos Territórios Disponível em < http://web.observatoriodasmetropoles.net> Acessado em outubro de 2009. .Produção do espaço e planejamento em áreas de transição rural-urbana: o caso da Região Metropolitana do Recife - PE. Tese de Doutorado. Recife: Universidade Federal de Pernambuco. CAC. Desenvolvimento Urbano, 2008.

NAKANO, K. O Plano Diretor e as zonas rurais. In SANTORO, Paula (Org.); PINHEIRO, Edie (Org.) O planejamento do município e o território rural. (Cadernos Pólis, 8) São Paulo, Instituto Pólis, 2004.

OLIVEIRA, R. A. Brasília e o paradigma modernista: planejamento urbano do moderno atraso. Tese de doutorado. USP, São Paulo, 2008.

PASSOS, L. A. Planejamento urbano e participação da população: labirinto democrático? Tese de doutorado: Brasília, UNB (2010), 212p.

PAVIANI, A. Demandas sociais e ocupação do espaço urbano. O caso de Brasília, DF. In: Cadernos Metrópole 21, pp. 75-92, 10 sem. 2009.

PAVIANI, A., BARRETO F.F.P., FERREIRA I.C.B., CIDADE L.C.F., JATOBÁ S.U. (Org.), Brasilia 50 anos: da capital a metrópole. Brasília: Editora UNB, 2010.

PÉBAYLE, R. A área rural do Distrito Federal Brasileiro. In: Revista Brasileira de Geografia, v. 33, no 1, 1971.

RIOS, L., Zaitune, M.P., Fittipaldi, R. ARIE Granja do Ipê - Área de Relevante Interesse Ecológico. 2014. Disponível em:https://www.facebook.com/ARIE.Granja.do.Ipe/posts/398282053659897. 
RUA, J. Continuidade ou Ruptura na Expansão da Metrópole para além de Seus Limites Formais: Urbanidades no Rural? In: RANDOLPG, R., SOUTHERN, B.C. (org.) Expansão metropolitana e transformação das interfaces entre cidade, campo e região na América Latina. São Paulo, Max Limonad, 2011.

RANDOLPG, R., SOUTHERN, B.C. (org.) Expansão metropolitana e transformação das interfaces entre cidade, campo e região na América Latina. São Paulo, Max Limonad, 2011.

SANO, E.E. et All. Estimativa da variação na demanda de água para irrigação por pivô-central no distrito federal entre 1992 e 2002. Revista Eng. Agric., Jaboticabal, v.25, n.2, p.508-515, maio/ago. $2005 . \quad$ Disponivel em: http://www.scielo.br/pdf/eagri/v25n2/26514

SANTORO, P. F. Planejar a expansão urbana: dilemas e perspectivas. Tese de Doutorado. FAU- USP. São Paulo. 2012.

. Cidades que crescem horizontalmente: o ordenamento territorial justo da mudança de uso rural para urbano. Cad. Metrop. São Paulo, v. 12, n. 24, pp. 417-440, jul/dez 2010.

SANTOS, M. A urbanização brasileira. São Paulo. Ed. Hucitec. 1994. . Espaço e método. São Paulo. Ed. Nobel. 1985. A natureza do espaço: técnica e tempo, razão e emoção. São Paulo. 4a ed. Edusp. 2002. Espaço e método. São Paulo. Edusp. 2008. In: BINSZTOK, J. (coord.). Território, territórios - ensaios sobre o ordenamento territorial. 3 ed. Rio de Janeiro, Lamparina, 2007.p.13-21.

SANTOS, M. SILVEIRA, M. L. O Brasil: território e sociedade no início do século XXI. São Paulo. Ed. Record, 2001.

SANZIO, R. BRASÍL IA - 50 ANOS DE DINÂMICA TERRITORIAL URBANA. Revista Eletrônica: Tempo - Técnica - Território, V.3, N.1 (2012), 1:24 ISSN: 2177-4366). 
SILVA, W. R. Reflexões em torno do urbano no Brasil. In: Sposito, M, E,B \& Whitacker, A. M. Cidade e campo - relações e contradições entre urbano e rural. São Paulo. Ed. Expressão Popular, 2010.

SILVA, M. A. S. A produção da habitação de interesse social no Distrito Federal e seus rebatimentos nos assentamentos irregulares na cidade modernista: o caso de Nova Colina. Dissertação de Mestrado. UFRJ, Rio de Janeiro, 2011.

SILVEIRA, D. P. F. Contribuições para o entendimento das mudanças no planejamento territorial do Distrito Federal. Dissertação de Mestrado. Brasília: Universidade de Brasilia. Faculdade de Arquitetura e Urbanismo. Mestrado em Planejamento Urbano. 1999.

SOBARZO, O. O urbano e o rural em Henri Lefebvre In: SPOSITO, M.E.B. \& WHITACKER, A.M. (org.) Cidade e Campo - relações e contradições entre urbano e rural. São Paulo, Editora Expressão Popular, 2a Ed. 2010.

SOUZA, M. A. A. O novo Brasil urbano: integração ou fragmentação? In: Gonçalves, M. F. O novo Brasil urbano; impasses, dilemas, perspectivas. Porto Alegre, Ed. Mercado Aberto, 1995.

SOUZA, M.L. Mudar a Cidade - Uma Introdução Crítica ao Planejamento e à Gestão Urbanos. Ed. Bertrand Brasil. Rio de Janeiro, 2002.

SPAROVEK, G. LEONELLI, G.C.V, BARRETO, A.G.O.P.A linha imaginária. In SANTORO, Paula (Org.); PINHEIRO, Edie (Org.) O planejamento do município e o território rural. (Cadernos Pólis, 8) São Paulo, Instituto Pólis, 2004.

SPOSITO, M.E.B. Formas espaciais e papéis urbanos: as novas qualidades da cidade e do urbano. In: CIDADES: Revista científica. V.7, n.11, 2010Formas espaciais e política(s) urbana(s). ISSN1679-3625. São Paulo: Ed. Expressão Popular; 2010.

STÉDILE, J. P. Questão Agrária. In: CALDART, R. S. (Org.) Dicionário da Educação do Campo. São Paulo. Expressão Popular. 2012.

STEINBERGER, M. (org). Território, ambiente e políticas públicas espaciais. Brasília: LGE editora. 2006. 
STIFELMAN, A. G., garcez, r. J. Do parcelamento do solo com fins urbanos em zona rural e da aplicação da lei n. ${ }^{\circ} 6.766 / 79$ e do provimento no 28/04 da cgj/rs (projeto more legal iii) Disponível em:

http://www.amprs.org.br/arquivos/comunicao noticia/DO\%20PARCELAMEN TO\%20DO\%20SOLO.pdf Acesso em 05/02/2011

TAVARES, J. A. S. Brasília Agrícola: Sua História. Brasília: BRB. 1995.

TAVARES, M.S.O.C., NETO, G.F., ARAGÃO, L.G.T., CARNEIRO, F.F., CÂNCIO, J., Construindo a Política Nacional de Saúde Ambiental - PNSA. 2004. Disponível em <http://dtr2001.saude.gov.br/editora/produtos/impressos/cartaz/04 0512 C.pdf> Acessado em outubro de 2009.

TERMO DE REFERENCIA. Concurso Público Nacional de Estudos Preliminares de Arquitetura e Paisagismo para o Parque do Paranoá / Região Administrativa VII Distrito Federal. SEDHAB, IAB, IBRAM. Brasília, 2012. Disponível em: http://www.concursossedhab.com.br/pp/bases/TERMO\%20DE\%20REFERENCIA PARA NOA R05.pdf

TESA, C.T.V. \& BAPTISTA, G.M.M. A supressão de vegetação e redução da área de sequestro florestal de carbono na Área Metropolitana de Brasília In: RIBEIRO, R.J.C., TENORIO, G.S., HOLANDA, F. (editores) Brasília: Transformações na ordem urbana. Metrópoles: Território, Coesão Social e Governança Democrática. Série estudos comparativos. Observatório das Metrópoles. Rio de Janeiro: Letra Capital, 2015.

UNESCO Vegetação do Distrito Federal: tempo e espaço. - 2.ed. - Brasília: UNESCO, 2002. 80p.

VEIGA, J.E. Cidades Imaginárias: O Brasil é menos urbano do que se calcula. 2aㅡ ed. Campinas/SP. Autores Associados. 2003.

VIEIRA, P.A., ALMEIDA, G.S., Buainaim,A.M.,RAMOS, P. O CENTRO-OESTE BRASILEIRO COMO FRONTEIRA AGRÍCOLA. Disponível em: http://www.sober.org.br/palestra/2/621.pdf. Acesso em 2/7/2015. 
VITTE, C.C.S. Cidadania, qualidade de vida e produção do espaço urbano: desafios para a gestão urbana e para o enfrentamento da questão social. In: BAENINGER R. (Org.) População e Cidades: subsidios para o planejamento e para as políticas sociais. Campinas, NEPO, UNFPA, 2010.

WANDERLEI, M.N.B. O mundo rural no Brasil: acesso a bens e serviços $e$ processos de integração. In Brasil rural em debate: coletânea de artigos. DELGADO, N.G. (org.) Brasília: CONDRAF/MDFA. 2010.

ZEE DF: Zoneamento Ecológico-Econômico do DF Subproduto 3.2 - Relatório do Diagnóstico. VOLUME III TEMA - USO DA TERRA. Disponível em:

http://www.zee-df.com.br/Arquivos\%20e\%20mapas/Volume\%20III\%20Uso\%20do\%20Solo,\%20JuridicoInstitucional,\%20Art.\%20RIDE\%20e\%20Fundi\%C3\%A1rio.pdf

\section{Internet:}

(Os sítios que estão sem data foram acessados e revisados em 20/10/2015)

http://www.caesb.df.gov.br/

http://www.ibram.df.gov.br/

http://www.brasil.gov.br/assuntos/geral/2010/04/carta-geografica/03 mapa-

FrancescoTosiColombina.jpg/view

http://www.museuvirtualbrasil.com.br/museu brasilia/modules/news3/article.php?st oryid=10 (foto candango)

http://www.lexml.gov.br/urn/urn:lex:br;distrito.federal:distrital:lei:1997-07-22;1572

http://jornalconversainformal.blogspot.com.br/2014/02/invasoes-desafiam-fiscaisarea.html fonte: Correio Braziliense - 18/02/2014

http://www.codeplan.df.gov.br/images/CODEPLAN/PDF/idecon/IdeconDF-

3 Trimestre.pdf

http://www.terracap.df.gov.br/portal/

http://www.vitruvius.com.br/revistas/read/minhacidade/07.074/1940

http://unb.br/noticias/unbagencia/unbagencia.php?id=3466 
http://www.caesb.df.gov.br/agua/saneamento-rural.html

http://verdecapital.org/category/agricultura-sustentavel-2/

http://www2.senado.leg.br/bdsf/bitstream/handle/id/57164/complemento 1.htm?se quence $=2$

http://www.correiobraziliense.com.br/app/noticia/cidades/

http://g1.globo.com/distrito-federal/noticia/2011/09/floresta-nacional-de-brasilia-

tem-mais-de-3-mil-moradores-irregulares.html

http://www.sedhab.df.gov.br/arquivos/pdot revisao 2007/versao cldf/perguntas res pondidas.pdf

https://www.facebook.com/ARIE.Granja.do.Ipe/posts/398282053659897

http://fabricadolivrodf.com.br/ra/riacho-fundo

http://www.folhadomeio.com.br/publix/fma/folha/2001/10/apas.html

http://www.rbma.org.br/mab/unesco 03 rb cerrado.asp

http://mtbbrasilia.com.br/2014/05/20/flona-comemora-seus-15-anos-com-

exposicoes-e-trilhas-de-bikes/

http://www.mi.gov.br/programas/desenvolvimentodocentrooeste/ride/index.asp acessado em dezembro de 2010. 